\title{
New Sesterterpenes from Marine Sponges from the Tropical Waters of the Kingdom of Tonga
}
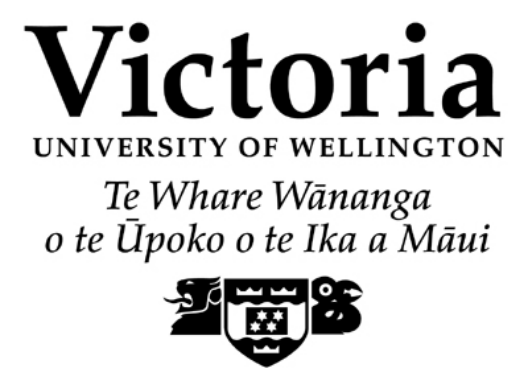

\author{
A thesis \\ submitted to Victoria University of Wellington \\ in fulfilment of the \\ requirements for the degree of \\ Master of Science \\ in Chemistry.
}

Victoria University of Wellington 2010 


\begin{abstract}
Over the course of this study, various species of Tongan marine sponges were investigated using an NMR-based screening method and has resulted in the discovery of three new sesterterpenes and 11 known compounds.

Examination of the sponge Fascaplysinopsis sp. resulted in the isolation of two novel sesterterpenes, isoluffariellolide (46) and 1-O-methylisoluffariellolide (47). Compounds 46 and 47 share the same backbone pattern as the known luffariellolide (45) and 25-Omethylluffariellolide (107) respectively, and differ only in the substitution pattern of the butenolide rings. Isoluffariellolide (46) was found to be approximately six times less cytotoxic than 1-O-methylisoluffariellolide (47). Interestingly, these results suggested that the 1-O-methyl group in compound 47 plays an important role in the cytotoxicity of the compound.
\end{abstract}

Secothorectolide (49), a new ring-opened and geometric isomer of the known compound thorectolide (48), was obtained from a sponge of the order Dictyoceratida. This ring closure and opening relationship was also observed between manoalide (109) and secomanoalide (110), as well as luffariellins A (141) and B (142). Despite the different carbon skeleton, the functional groups in $\mathbf{1 4 1}$ and 142 are similar with those in $\mathbf{1 0 9}$ and 110, respectively, and not surprisingly the biological properties are almost identical. The biological activities of compounds $\mathbf{4 8}$ and $\mathbf{4 9}$ were almost the same, which would give an insight into the structure-activity relationship (SAR) between these types of compounds.
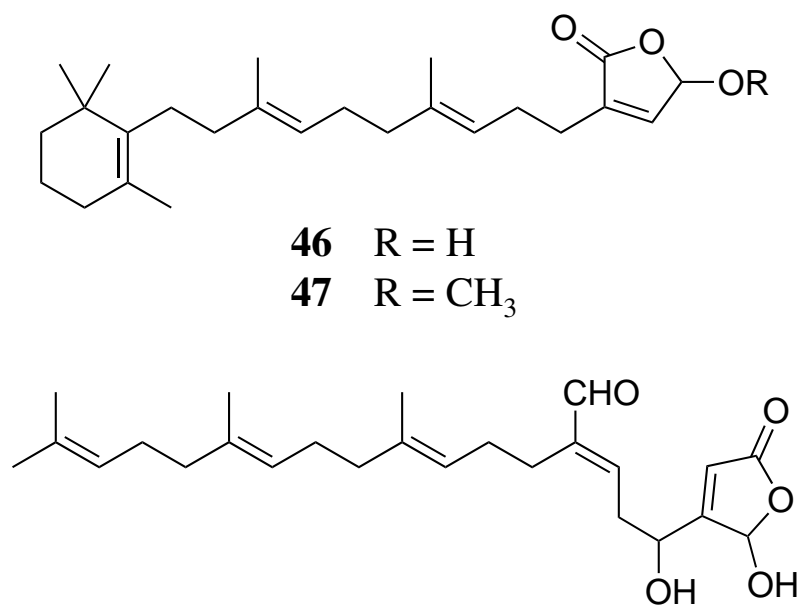

49 


\section{Acknowledgments}

It is a pleasure to thank the many people who made this thesis possible, but I would like to give the glory back to the Heavenly Father who Has given me the wisdom and strength to carry out this study to the end.

First and foremost I offer my sincerest gratitude to my supervisor, Assoc. Prof. Peter Northcote, whose encouragement, guidance and support from the initial to the final level enabled me to develop an understanding of the subject. Without his encouragement and constant guidance, I could not have finished this thesis. One simply could not wish for a better or friendlier supervisor. Thank you for accepting me to work in your lab and the series of dive trips back home.

In my daily work in the lab I have been blessed with friendly and cheerful workmates, Jonathan Singh and Jacqueline Barber. I am heartily thankful to Jono, who is always being there to help me with my lab work and to edit my thesis. Jono has been a friend and mentor. Jacqui thank you for always explaining things more clearly to my small Tongan brain.

I wish to thank Dr John Ryan for his amazing NMR skills and for retriving my unsaved NMR data after being lost for more than a year. Thank you for introducing and helping me get on the road to $\mathrm{LT}_{\mathrm{E}} \mathrm{X}$.

My sincere thanks go to the academic and general staff at the School of Chemical and Physical Sciences.

The School of Biological Sciences has kindly run a range of bioassays on my compounds, special thanks to Prof. John Miller and Dora Leahy from the Cell Biology Research group.

For special gratitude is due to my parents, Temaleti and Siopau, for always believing in me and all the prayers. To my aunties, Drs 'Anamaui Taufe 'ulungaki and Sepi Taufe 'ulungaki for always being there throughout my academic years. To aunty Vika for always making her house available for us during our diving collecting trips. To my sisters (Mepa, Malama, Seini) and brothers (Maikolo, Mosese Tava, Kanitiola) for everything.

I owe my loving thanks to my wife Salome Visitasio, and my daughter 'Iunisi Tupou. They have lost a lot due to my research abroad. Without their encouragement and understanding it would have been impossible for me to finish this work.

The financial support of the NZAiD is gratefully acknowledged. 


\section{Table of Contents}

Abstract

Acknowledgments

Table of Contents $\quad$ iv

List of Figures viii

List of Schemes $\quad$ xi

List of Tables $\quad$ xii

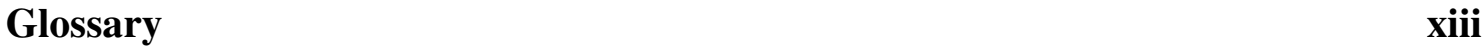

1 Introduction 1

1.1 The Role of Natural Products in Medicine . . . . . . . . . . . . . . . . 1

1.2 The Onset of the "Golden Era of Antibiotics" . . . . . . . . . . . 2

1.3 Marine Natural Products . . . . . . . . . . . . . . . . . . . 3

1.4 Marine Sponges . . . . . . . . . . . . . . . . . . . 5

1.5 Tongan Marine Sponges and Chemistry . . . . . . . . . . . . 7

2 Isolation and Screening of Secondary Metabolites $\quad 14$

2.1 Isolation Techniques $\ldots \ldots \ldots \ldots \ldots$

2.1 .1 Cyclic Loading . . . . . . . . . . . . . . . . . . . . . . 14

2.2 Screening of Marine Organisms _. . . . . . . . . . . . . 16

2.2.1 Bioassay-Directed Screening . . . . . . . . . . . . . . 16

2.2.2 NMR-Based Screening . . . . . . . . . . . . . . 17

2.3 VUW Screening Methodology . . . . . . . . . . . . . . . . . 17

2.3 .1 HSQC Mask . . . . . . . . . . . . . . . . . . 18 
2.4 Future Screening Methods . . . . . . . . . . . . . . . . . . . . . 19

2.4 .1 HMBC Screen . . . . . . . . . . . . . . . 20

3 Sponges Investigated by Spectroscopic Screening 21

3.1 Sponges Screened from Tongatapu and 'Eua . . . . . . . . . . . . . 21

3.2 Sponges Screened from the Vava'u Group . . . . . . . . . . . . . . . 26

4 The Isolation of Known Compounds from Tongan Sponges 29

4.1 Order Verongida . . . . . . . . . . . . . . . . . . . . . . . . 29

4.1.1 Bromotyrosine Derivatives . . . . . . . . . . . . 29

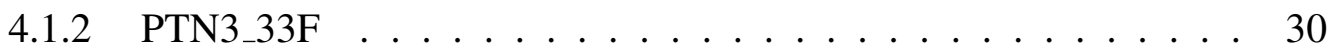

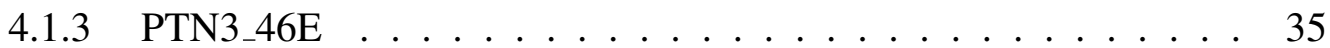

4.2 Order Poecilosclerida . . . . . . . . . . . . . . . . . . . . 45

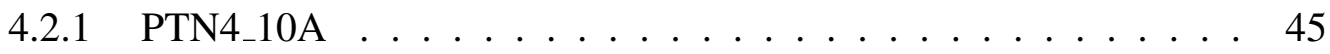

4.3 Biological Activity . . . . . . . . . . . . . . . 51

5 Investigation of Fascaplysinopsis sp.

5.1 Fascaplysinopsis sp. ...................... 52

5.2 Chemical History of the Genus Fascaplysinopsis _ . . . . . . . . . . 53

5.3 Isolation . . . . . . . . . . . . . . . . . . 59

5.4 Isoluffariellolide . . . . . . . . . . . . . . . . . . 61

5.5 1-O-Methylisoluffariellolide . . . . . . . . . . . . . . 67

5.6 Biological Activity . . . . . . . . . . . . . . . . . . . 74

5.7 Related Compounds . . . . . . . . . . . . . . . . . . . . 74

6 Investigation of Sponge from the Order Dictyoceratida 80

6.1 Order Dictyoceratida f . . . . . . . . . . . . . . . 80

6.2 Isolation . . . . . . . . . . . . . . . . . . . 81

6.3 Secothorectolide ...................... 83 
6.4 Biological Activity . . . . . . . . . . . . . . . 88

6.5 Related Compounds . . . . . . . . . . . . . . . . . . . . 88

6.5.1 Biosynthetic relationship between all Luffarella metabolites . . 90

7 Conclusion $\quad 92$

8 Experimental $\quad 94$

8.1 General Experimental . . . . . . . . . . . . . . . . . . . . . 94

8.2 Investigation of Genus Fascaplysinopsis . . . . . . . . . . . . . . . 95

8.2.1 Initial Fractionation of Fascaplysinopsis sp. . . . . . . . . . . . 95

8.2.2 Isolation of Homofascaplysin A . . . . . . . . . 96

8.2.3 Isolation of Luffariellolide, Isoluffariellolide, 1-O-Methylisoluffariellolide ...................... 96

8.3 Investigation of Dictyoceratid Sponge $\ldots \ldots . \ldots . \ldots 9$

8.3.1 Isolation of Secothorectolide and Thorectolide . . . . . . . . 9 98

8.4 Investigation of a Verongiid Sponge . . . . . . . . . . . . . 100

8.4.1 Isolation of Aplysamine-2 and Aerophobin-1 . . . . . . . . 100

8.5 Investigation of Verongiid Sponge . . . . . . . . . . . . . . 102

8.5.1 Isolation of Fistularin-3, Aeroplysinin-1 and LL-PAA216 . . . . 102

8.6 Investigation of a Poecilosclerid Sponge . . . . . . . . . . . . . 104

8.6.1 Isolation of of Makaluvamine G and Prianosin B . . . . . . . 104

$\begin{array}{lll}\text { A Existing Marine Chemistry Sponge Screening Protocol } & 107\end{array}$

$\begin{array}{lr}\text { B Isoluffariellolide Spectra } & 113\end{array}$

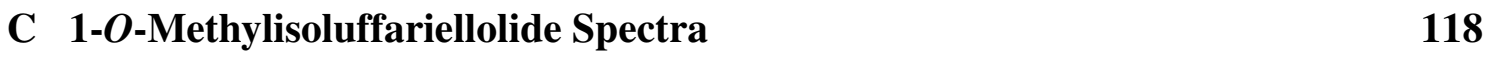

$\begin{array}{lr}\text { D Secothorectolide Spectra } & 123\end{array}$

$\begin{array}{lrr}\text { E } & \text { Fistularin-3 Spectra } & 128\end{array}$ 
F Aeroplysinin-1 Spectra

G LL-PAA216 Spectra

H LL-PAA216 Spectra

References

148 


\section{List of Figures}

1.1 Map of the Kingdom of Tonga. Map courtesy of LINZ. . . . . . . . . . . 8

2.1 Schematic of the mass distribution in a typical marine sponge extract. . . 15

2.2 Schematic of the cyclic loading process. . . . . . . . . . . . 16

2.3 (a) Computer generated mask of HSQC data (contains 160 sponges). (b) Common correlations in the HSQC masks. . . . . . . . . . . . . . . . . . 19

2.4 (a) An uninteresting sponge screen. (b) An interesting screen. . . . . . . . 19

3.1 Surface photo of the PTN3_13A sponge. . . . . . . . . . . . 21

3.2 Surface photo of the PTN3_13C sponge. . . . . . . . . . . . . . 22

3.3 Surface photo of the PTN3_14B sponge. . . . . . . . . . . . . . . 22

3.4 Surface photo of the PTN3_14E sponge. . . . . . . . . . . . . 23

3.5 Surface photo of the PTN3_14F sponge. . . . . . . . . . . . . 23

3.6 Surface photo of the PTN3_15C sponge. . . . . . . . . . . . . . . 24

3.7 Surface photo of the PTN3_16F sponge. . . . . . . . . . . . . . 24

3.8 Surface photo of the PTN3_18C sponge. . . . . . . . . . . . . 25

3.9 Surface photo of the PTN3_25E sponge. . . . . . . . . . . . 26

3.10 Surface photo of the PTN3_25F sponge. . . . . . . . . . . . . 27

3.11 Underwater photo of the Leucetta sp. (courtesy of Karen Stone). . . . . . 27

3.12 Surface photo of the PTN4_05D. . . . . . . . . . . . 28

4.1 Surface photograph of the sponge PTN3_33F . . . . . . . . . . . 30

4.2 HSQC NMR screen spectrum $\left(600 \mathrm{MHz}, \mathrm{CD}_{3} \mathrm{OD}\right)$ of the $75 \% \mathrm{Me}_{2} \mathrm{CO} / \mathrm{H}_{2} \mathrm{O}$ fraction of PTN3_33F. . . . . . . . . . . . . . . 33

4.3 COSY NMR screen spectrum $\left(600 \mathrm{MHz}, \mathrm{CD}_{3} \mathrm{OD}\right)$ of the $75 \% \mathrm{Me}_{2} \mathrm{CO} / \mathrm{H}_{2} \mathrm{O}$ fraction of PTN3_33F. . . . . . . . . . . . . 33

4.4 ${ }^{1} \mathrm{H}$ NMR screen spectrum $\left(600 \mathrm{MHz}, \mathrm{CD}_{3} \mathrm{OD}\right)$ of the $75 \% \mathrm{Me}_{2} \mathrm{CO} / \mathrm{H}_{2} \mathrm{O}$ fraction of PTN3_33F. . . . . . . . . . . . . 34 
4.5 HMBC NMR screen spectrum $\left(600 \mathrm{MHz}, \mathrm{CD}_{3} \mathrm{OD}\right)$ of the $75 \% \mathrm{Me}_{2} \mathrm{CO} / \mathrm{H}_{2} \mathrm{O}$ fraction of PTN3 33F. . . . . . . . . . . . . . 34

4.6 Underwater photograph of the sponge PTN3_46E. Courtesy of Karen Stone. 35

4.7 Proposed substructure of a compound isolated from PTN3_46E sponge. . 39

4.8 Underwater photo of the PTN4_10A sponge (courtesy of Karen Stone). . 46

4.9 HSQC NMR screen spectrum (600 MHz, $\left.\mathrm{CD}_{3} \mathrm{OD}\right)$ of the $75 \% \mathrm{Me}_{2} \mathrm{CO} / \mathrm{H}_{2} \mathrm{O}$ fraction of PTN4_10A. . . . . . . . . . . . . . . . 49

4.10 COSY NMR screen spectrum (600 MHz, $\left.\mathrm{CD}_{3} \mathrm{OD}\right)$ of the $75 \% \mathrm{Me}_{2} \mathrm{CO} / \mathrm{H}_{2} \mathrm{O}$ fraction of PTN4_10A. . . . . . . . . . . 50

4.11 HMBC NMR screen spectrum $\left(600 \mathrm{MHz}, \mathrm{CD}_{3} \mathrm{OD}\right)$ of the $75 \% \mathrm{Me}_{2} \mathrm{CO} / \mathrm{H}_{2} \mathrm{O}$ fraction of PTN4_10A. . . . . . . . . . . . . . . 50

5.1 Surface photograph of the Fascaplysinopsis sp. . . . . . . . . . . . . 53

5.2 COSY and HMBC correlations establishing connectivity of C-16 to C-18 of isoluffariellolide. . . . . . . . . . . . . . 61

5.3 HMBC correlations establishing connectivity of the trimethylcyclohexenyl ring system, substructure A, of isoluffariellolide. . . . . . . . . . . 62

5.4 COSY and HMBC correlations establishing connectivity of C-10 to C-13, substructure $\mathrm{B}$, of isoluffariellolide.

5.5 COSY and HMBC correlations establishing connectivity of C-6 to C-9, substructure $\mathrm{C}$, of isoluffariellolide. . . . . . . . . . . . . 63

5.6 COSY and HMBC correlations establishing connectivity of the $\alpha$-sustituted$\gamma$-hydroxybutenolide ring, substructure D, of isoluffariellolide. . . . . . . 64

5.7 COSY and HMBC correlations establishing connectivity of C-18 to C-16 of $1-O$-methylisoluffariellolide. . . . . . . . . . . . . . 67

5.8 HMBC correlations establishing connectivity of the trimethylcyclohexenyl ring moiety, substructure A, of 1-O-methylisoluffariellolide. . . . . . 68

5.9 COSY and HMBC correlations establishing connectivity of C-9 to C-6 of $1-O$-methylisoluffariellolide. . . . . . . . . . . . . . . . 69

5.10 COSY and HMBC correlations establishing connectivity of C-13 to C-6, substructure $\mathrm{B}$, of 1-O-methylisoluffariellolide.

5.11 COSY and HMBC correlations establishing connectivity of the $\alpha$-substituted$\gamma$-methylbutenolide ring, substructure $\mathrm{C}$, of 1- $O$-methylisoluffariellolide. . 70

6.1 Surface photograph of the sponge PTN3_21C . . . . . . . . . . . 80 
6.2 COSY and HMBC correlations establishing connectivity of the terminal isoprene unit, substructure A, of secothorectolide. . . . . . . . . . . . 84

6.3 COSY and HMBC correlations establishing connectivity of the isoprene units, substructure B, of secothorectolide. . . . . . . . . . . . 84

6.4 COSY and HMBC correlations establishing connectivity of the isopropene unit, substructure $\mathrm{C}$, of secothorectolide. . . . . . . . . . . 85

6.5 COSY and HMBC correlations establishing connectivity of the isopropene unit, substructure $\mathrm{D}$, of secothorectolide. . . . . . . . . . 86 


\section{List of Schemes}

4.1 Isolation of aplysamine-2 and aerophobin-1 from PTN3 33E, collected from Vava'u, Tonga. . . . . . . . . . . . . . . . . . . . 31

4.2 Isolation of fistularin-3, aeroplysinin-1 and LL-PAA216 from PTN3_46E, collected from Vava'u, Tonga. . . . . . . . . . . . . . . 36

4.3 Isolation of makaluvamine $\mathrm{G}$ and prianosin B from PTN4_10A, collected from Vava'u, Tonga. . . . . . . . . . . . . . . . . . 47

5.1 Isolation of homofascaplysin A, isodehydroluffariellolide, luffariellolide, isoluffariellolide and 1-O-methylisoluffariellolide from Fascaplysinopsis sp. collected from 'Eua, Tongatapu. . . . . . . . . . . . . . . . . . . 60

6.1 Isolation of thorectolide and secothorecetolide from PTN3_21C, collected from 'Eua, Tongatapu. . . . . . . . . . . . . . . . . . . . 82

6.2 Postulated biosynthetic relationship between all known Luffariella metabolites. . . . . . . . . . . . . . . . . . . . . 91 


\section{List of Tables}

1.1 Taxonomic Classification to Order Level of Phylum Porifera. . . . . . . . 7

4.1 Taxonomic Classification of the Order Verongida. . . . . . . . . . . . . . 29

$4.2{ }^{15} \mathrm{~N}(60 \mathrm{MHz}),{ }^{13} \mathrm{C}(150 \mathrm{MHz})$ and ${ }^{1} \mathrm{H}(600 \mathrm{MHz}) \mathrm{NMR}$ Data $\left(\mathrm{CD}_{3} \mathrm{OD}\right)$ for Fistularin-3. . . . . . . . . . . . . . . . . 41

$4.3{ }^{15} \mathrm{~N}(60 \mathrm{MHz}),{ }^{13} \mathrm{C}(150 \mathrm{MHz})$ and ${ }^{1} \mathrm{H}(600 \mathrm{MHz}) \mathrm{NMR}$ Data $\left(\mathrm{CD}_{3} \mathrm{OD}\right)$ for Aeroplysinin-1. . . . . . . . . . . . . . . . 42

$4.4{ }^{15} \mathrm{~N}(60 \mathrm{MHz}),{ }^{13} \mathrm{C}(150 \mathrm{MHz})$ and ${ }^{1} \mathrm{H}(600 \mathrm{MHz}) \mathrm{NMR}$ Data $\left(\mathrm{CD}_{3} \mathrm{OD}\right)$ for LL-PAA216. . . . . . . . . . . . . . . . . . . 4 43

$4.5{ }^{15} \mathrm{~N}(60 \mathrm{MHz}),{ }^{13} \mathrm{C}(150 \mathrm{MHz})$ and ${ }^{1} \mathrm{H}(600 \mathrm{MHz}) \mathrm{NMR}$ Data $\left(d_{6}\right.$-DMSO $)$ for LL-PAA216. . . . . . . . . . . . . . . . . . . . . 44 4

4.6 Taxonomic Classification of Selected Families of the Order Poecilosclerida .......................... 45

5.1 Taxonomic classification of genus Fascaplysinopsis from Class Demospongiae. . . . . . . . . . . . . . . . 52

5.2 Comparison of the ${ }^{1} \mathrm{H}$ and ${ }^{13} \mathrm{C}$ NMR chemical shifts $\left(\mathrm{CDCl}_{3}\right)$ of the $\gamma$ hydroxybutenolide ring of isoluffariellolide, luffariellolide, and dictyodendrillin C . . . . . . . . . . . . . . . . . . . . . 65

$5.3{ }^{13} \mathrm{C}(150 \mathrm{MHz})$ and ${ }^{1} \mathrm{H}(600 \mathrm{MHz})$ NMR Data $\left(\mathrm{CDCl}_{3}\right)$ for Isoluffariellolide. . . . . . . . . . . . . . . 66

5.4 Comparison of the ${ }^{1} \mathrm{H}$ and ${ }^{13} \mathrm{C}$ NMR Chemical Shifts of the Butenolide Ring of Isoluffariellolide, 1- $O$-Methylisoluffariellolide, 25- $O$-Methylluffariellolide, and 1 - $O$-Ethylhyrtiolide. . . . . . . . . . . . . . . 72

5.5 ${ }^{13} \mathrm{C}(150 \mathrm{MHz})$ and ${ }^{1} \mathrm{H}(600 \mathrm{MHz}) \mathrm{NMR}$ data $\left(\mathrm{CDCl}_{3}\right)$ for 1-O-Methylisoluffariellolide. 73

6.1 Taxonomic classification of the order Dictyoceratida. . . . . . . . . . 81

$6.2{ }^{13} \mathrm{C}(150 \mathrm{MHz})$ and ${ }^{1} \mathrm{H}(600 \mathrm{MHz}) \mathrm{NMR}$ Data $\left(\mathrm{CDCl}_{3}\right)$ for Secothorectolide. 87 


\section{Glossary}

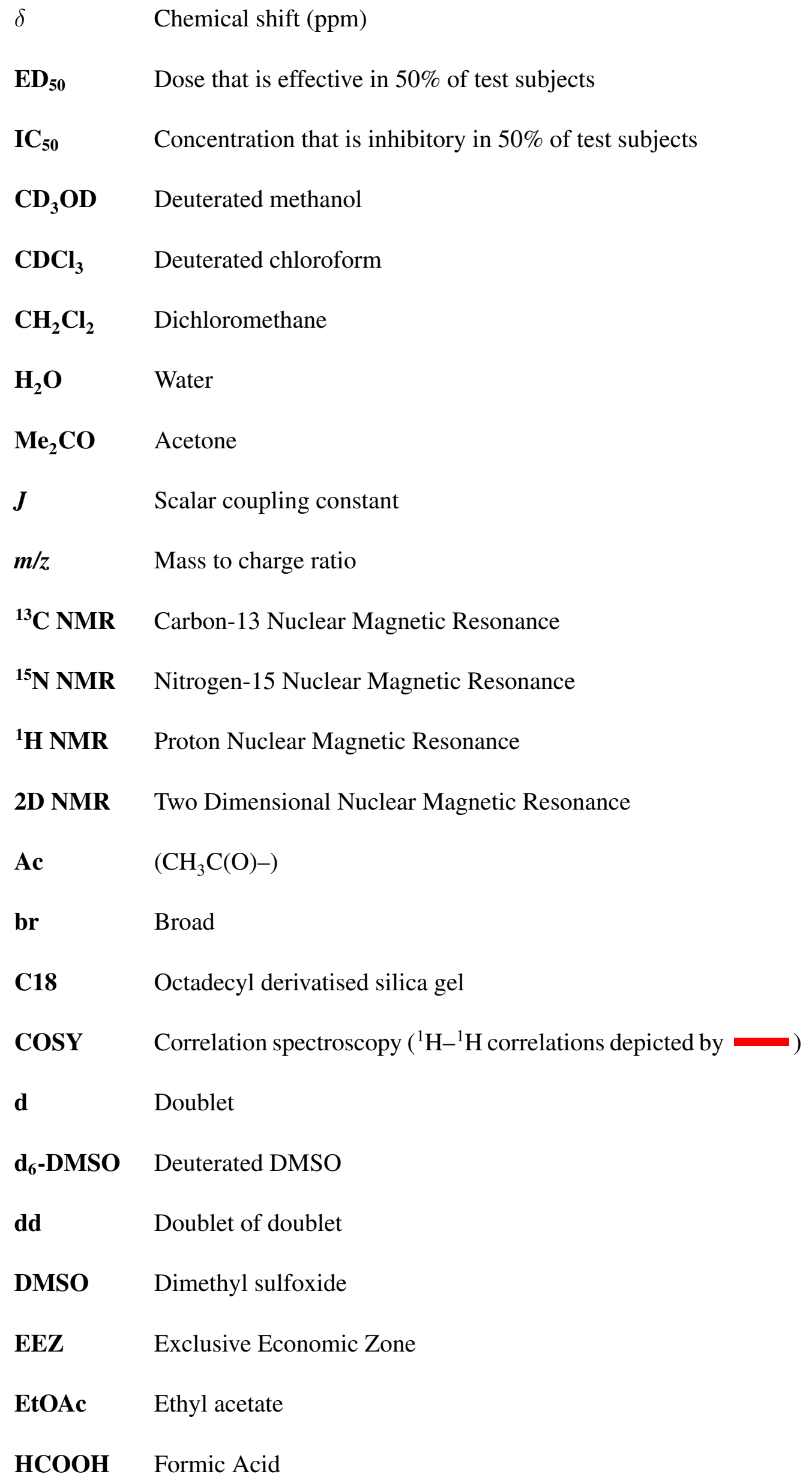


HMBC Heteronuclear Multiple Bond Correlation $\left({ }^{1} \mathrm{H}\right.$ to ${ }^{13} \mathrm{C}$ correlations depicted by $\longrightarrow$ )

HP20 PSDVB stationary support

HP20SS PSDVB stationary support

HPLC High Pressure Liquid Chromatography

HRESIMS High Resolution Electro-Spray Ionisation Mass Spectrometry

HSQC Heteronuclear Single Quantum Coherence

m Multiplet

MeOH Methanol

MS Mass Spectrometry

NMR Nuclear Magnetic Resonance

NOE Nuclear Overhauser Effect

pet. ether Petroleum ether (hexanes)

ppm Parts per million

PSDVB Poly(styrene-divinylbenzene)

S Singlet

SCUBA Self Contained Underwater Breathing Apparatus

t Triplet

TLC Thin Layer Chromatography

VUW Victoria University of Wellington 


\section{Chapter 1}

\section{Introduction}

\subsection{The Role of Natural Products in Medicine}

Historically, humankind has constantly relied on Nature to improve various aspects of our life. Nature has provided our basic needs for survival such as sources of food, shelter, textiles, cosmetics and medicines. ${ }^{1}$ Terrestrial plants have been the basis for traditional medicines and herbal remedies for centuries and have been widely documented in many cultures. Records as early as $2600 \mathrm{BC}$ from Mesopotamia on the use of plant materials in medicine were written on hundreds of clay tablets in cuneiform. ${ }^{1}$ In ancient Egypt, medicines were used as early as 2900 BC, and the "Eber Papyrus" (written in about 1500 $\mathrm{BC}$ ) is the best known medical text from this era, documenting over 700 (mostly plantbased) medicines. ${ }^{2}$ The Chinese "Materia Medica", has been repeatedly documented over centuries $(\sim 1100 \mathrm{BC})$ along with the "Shennong Herbal" ( 100 BC) and the "Tang Herbal" (659 AD), documented the uses of thousands of plants as drugs or medicines. ${ }^{2}$ The Indian Ayurveda (1000 BC) described in detail the uses of over 1000 different drugs or remedies. ${ }^{1,2}$ In the Western World, Greeks and Romans contributed to the development of the use of herbal medicines from around $300 \mathrm{BC}$, but it was the Arabs that were responsible for maintaining and expanding this knowledge. ${ }^{1-3}$

The therapeutic effect of these traditional medicines is generally due to biologically active secondary metabolites present within the plant material. However, the study of secondary metabolites (also known as natural products) from terrestrial plants only began in the 1800s, where scientists isolated, purified, and defined these active substances. Subsequently, countless numbers of biologically active compounds have been isolated from terrestrial sources, many of which are used as modern-day drugs for treating various diseases and other medicinal purposes. For example, ancient texts from Mesopototamia indicated the use of poppy juice from the opium poppy (Papaver somniferum) for therapeutic means. But it was not until 1806 when the active compound, the narcotic 
analgesic morphine (1), was isolated by Serturner. ${ }^{4}$ Morphine is considered as the first bioactive compound isolated from Nature and the first commercialised pure natural product used for medical purposes. ${ }^{4}$ Moreover, the "Eber Papyrus" mentioned the use of willow leaves as an antipyretic treatment. The Greeks and the Romans also discovered the antipyretic and analgesic properties of willow bark around 400 BC. In the mid 1800s, the bioactive compound salicin (2), was discovered, although it was its derivatives, salicylic acid (3) and aspirin (acetylsalicylic acid, 4) that were commercialised in 1899. ${ }^{4}$ Aspirin (4) was the first semi-synthetic drug based on a natural product, and features as the most successful and widely used medication worldwide. ${ }^{3,4}$

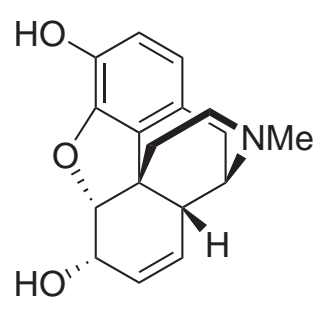

1

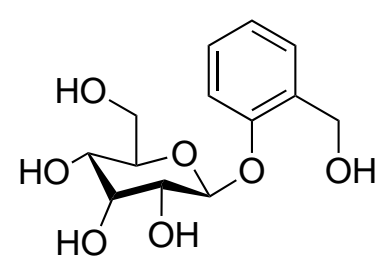

2<smiles>O=C(O)c1ccccc1O</smiles>

$3 \mathrm{R}=\mathrm{H}$

$4 \mathrm{R}=\mathrm{Ac}$

\subsection{The Onset of the "Golden Era of Antibiotics"}

The serendipitous discovery of penicillin G (5) from the fungus Penicillium notatum in 1929 heralded the modern era of antibiotics. ${ }^{1,2}$ This discovery signaled what many then believed to be the end of infectious disease. Followed by the success of largescale production of penicillin during the World War II, pharmaceutical companies and scientists all over the world shifted their focus to the newly discovered world of microbes. ${ }^{5}$ From the 1940 s to the 1970 s, microbes were found to be prolific sources of structurally diverse, biologically active metabolites. This led to the discovery of new antibiotics ranging from antibacterial agents such as penicillins, aminoglycosides (e.g. streptomycin, 6), antiparasitic drugs (e.g. ivermectins) to immunosuppressive agents such as rapamycin (also known as sirolimus, 7). ${ }^{1,2,5}$ This large collection of bioactive metabolites served as the modern foundation for the treatment of infectious disease, and along with the introduction of better hygiene standards, led to a dramatic reduction in worldwide morbidity and mortality due to bacterial infections. ${ }^{6}$ About onehalf of the drugs commonly used today were discovered during this era, referred to 
as the "Golden Age of Antibiotics". ${ }^{6}$ Unfortunately, this period has been short-lived, due to the resurgence of disease-causing pathogens and parasites that have developed resistance to these chemotherapies. ${ }^{7}$ Today, natural product chemists and pharmacologists are increasingly turning to new sources in the search for biologically active compounds, especially the marine realm. ${ }^{7}$<smiles>CC1(C)S[C@@H]2[C@H](NC(=O)Cc3ccccc3)C(=O)N2[C@H]1C(=O)O</smiles>

5<smiles>CN[C@H]1[C@H](OC2[C@H](O[C@@H]3[C@@H](O)[C@H](O)[C@@H](N=C(N)N)[C@H](O)[C@H]3N=C(N)N)O[C@H](C)[C@@]2(C)O)O[C@H](CO)[C@@H](O)[C@@H]1O</smiles>

6

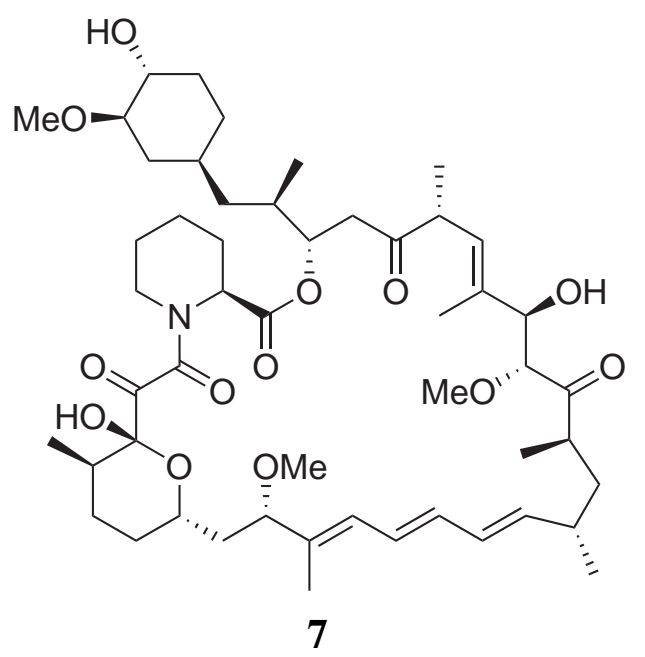

\subsection{Marine Natural Products}

The marine environment covers more than $70 \%$ of our planet's surface and life on Earth has its origin in the sea. ${ }^{8}$ This environment contains 34 of the 36 known phyla of life and offers a greater biodiversity than that of the terrestrial environment. ${ }^{9}$ Secondary metabolites isolated from the marine environment often have unusual and complex structures with unique functionalities and possess pronounced biologically activity. This is due partially to the harsh and extreme environments in which the marine organisms may inhabit, such as high salinity, extreme pressure, low light intensity, variable temperature and low nutrient availability. Because environmental conditions in the 
marine environment are so noticeably distinct, the chemistry produced by its inhabitants is also quite varied. As the terrestrial sources of pharmaceuticals and biochemicals have been considerably explored, less than $1 \%$ percent of marine species have been examined for novel chemistry. ${ }^{10-13}$ Thus, the oceans represent a rich and still largely untapped resource for biologically active compounds. In addition, completely unknown biochemical pathways in pathogens or disease may be discovered and targeted by such unique chemotypes, leading to the development of novel therapeutics.

Marine natural products were largely unexplored because of the difficulties involved in collecting samples. The development of technologies such as SCUBA in the 1950s, and more recently submersible vehicles, has allowed underwater exploration in both shallowand deep-water more achievable. The first therapeutic agents from marine environment were reported in the 1950s by Bergmann et al. through their discovery and isolation of two novel biologically active nucleosides, spongouridine (8) and spongothymidine (9), from a Caribbean marine sponge Crypotethia crypta. ${ }^{14-16}$ Subsequent development of synthetic analogues has provided clinically relevant agents, including the anti-HIV drug azidothymidine (AZT, 10), the antiviral agent vidarabine (Ara-A, 11) and the arabinosyl cytosine (Ara-C, 12). Compound 12 in particular is the first marine-derived anti-cancer agent, used for the treatment of acute myelocytic leukemia and non-Hodgkin's lymphoma. ${ }^{17}$ The discovery and development of compounds 8 and 9 created interest in the marine derived secondary metabolites and is considered to be the first significant discovery of biologically active compounds from the marine environment. Since then, through combined efforts, marine natural product chemists and pharmacologists have isolated an impressive number of promising compounds that are either already at advanced stages of clinical trials (mostly in the treatment of cancer), or have been selected as promising candidates for extended preclinical evaluation. ${ }^{18}$ The majority of these compounds are produced by invertebrates such as sponges, tunicates, soft corals, sea squirts, molluscs or bryozoans. 


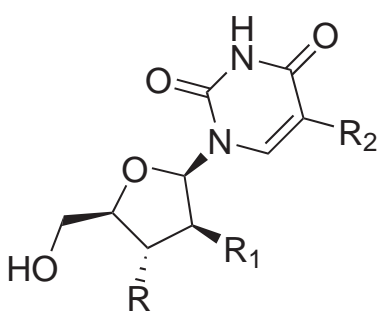

$8 \quad \mathrm{R}=\mathrm{OH} \quad \mathrm{R}_{1}=\mathrm{OH} \quad \mathrm{R}_{2}=\mathrm{H}$

$9 \quad \mathrm{R}=\mathrm{OH} \quad \mathrm{R}_{1}=\mathrm{OH} \quad \mathrm{R}_{2}=\mathrm{Me}$

$10 \quad \mathrm{R}=\mathrm{N}_{3} \quad \mathrm{R}_{1}=\mathrm{H} \quad \mathrm{R}_{2}=\mathrm{Me}$

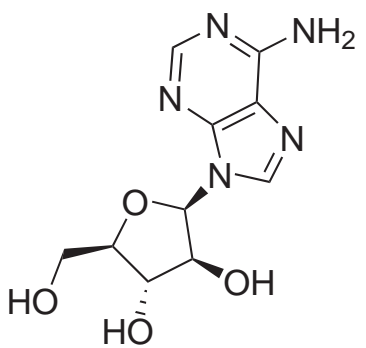

11

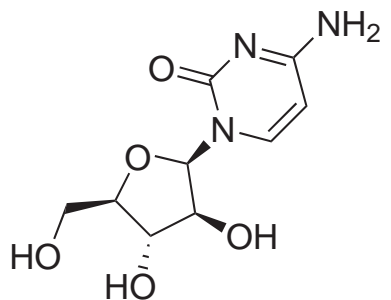

12

\subsection{Marine Sponges}

Marine sponges, or poriferans (from Latin porus "pore", and ferre "to bear"), belong to phylum Porifera, and are considered to be the most primitive group of multicellular animals because they do not have true organs or tissues. ${ }^{19}$ For this reason, sponges were excluded from the animal kingdom until the late 1800s. ${ }^{19}$ Sponges are ubiquitous benthic creatures, found at all latitudes beneath the world's oceans, from intertidal zones to the deep sea. Molecular genetics evidence placed the divergence of sponges to around 800 million years ago, ${ }^{20}$ suggesting that sponges were widespread inhabitants of the reefs and their simplistic nature was a highly successful and persistent one. ${ }^{19}$ At this time, about 15,000 extant species have been described, and there are possibly twice as many undescribed species. ${ }^{21}$

Sponges are simple multicellular invertebrates that filter large quantities of seawater and acquire nutrients by phagocytosis of captured bacteria. ${ }^{22}$ They are sessile, softbodied, and are prone to predation and other environmental stress factors. Sponges have experienced an intense evolutionary pressure to evolve and produce biologically active and antagonistic metabolites. These compounds are rapidly diluted after being released into the water and hence have to be of outstanding potency to retain their efficacy. ${ }^{8}$ These secondary metabolites serve as a chemical defense mechanism which compensates for their lack of morphological defense structure, such as spines or a protective shell. This is no coincidence but it reflects the ecological importance of these constituents for the marine sponge. A great diversity of highly toxic compounds or distasteful metabolites is an effective strategy to fight off potential predators or to force back neighbours competing for space. ${ }^{18}$ These metabolites affect numerous biological targets which make these 
organisms of great interest to marine natural products chemists and pharmacologists.

Most of the known species of sponges feed on bacteria and some host photosynthesising micro-organisms in an endosymbiotic relationship. ${ }^{22}$ Some sponges have been shown to harbour a large number of bacteria, in some cases up to $60 \%$ of the tissue volume. ${ }^{23}$ The sponges provide the micro-organisms with a protected environment for growth and reproduction, and the sponges obtain oxygen and nutrients from the micro-organisms. Due to this relationship, there is an uncertainty as whether the biologically active metabolites isolated from sponges are in fact produced by the sponges or the microorganisms. Recent studies have shown that a number of secondary metabolites can be attributed to the symbiotic micro-organisms. ${ }^{24,25}$

Sponges display an incredible variety of colours and shapes. In general, sponge species are difficult to identify by casual comparison to some illustration or photograph. Sponges have indeterminate growth patterns, such as shape, size, colour and showed considerable plasticity in response to environmental factors and location. The lack of structural features make them hard to characterise, which leads to problems with their classification. However, most sponges have spicules; microscopic skeletal structures that provide support and sometimes deter predators. Comparison of the shapes and sizes of these spicules found in the sponge with data from the literature aid the identification of sponge species (since spicules are the only consistent structures in sponges). From these characterisations, the Porifera have been divided into three classes: Hexactinellida (siliceous/glass spicules), Calcarea (spicules of crystalline $\mathrm{CaCO}_{3}$ ) and Demospongiae (siliceous spicules and/or collagen fibres). ${ }^{21}$ The largest class, Demospongiae contains about $90 \%$ of the sponge species within 15 orders and 25 families. The Calcarea is divided into 24 families within five orders, and the class Hexactinellida contains five orders and 17 families (Table 1.1). ${ }^{21}$ Recently, different techniques have also been used as tools in sponge taxonomic classification such as chemotaxanomic trends and molecular biology, leading to the re-examination of sponge taxonomy at the order level and below. ${ }^{26}$ 
Table 1.1. Taxonomic Classification to Order Level of Phylum Porifera. ${ }^{21}$

\begin{tabular}{|c|c|c|c|c|}
\hline Kingdom & Phylum & Class & Sub-class & Order \\
\hline \multirow{7}{*}{ Metazoa } & \multirow{7}{*}{ Porifera } & \multirow[t]{3}{*}{ Demospongiae } & Ceractinomorpha & $\begin{array}{l}\text { Agelasida } \\
\text { Dendroceratida } \\
\text { Dictyoceratida } \\
\text { Halichondrida } \\
\text { Halisarcida } \\
\text { Haplosclerida } \\
\text { Poecilosclerida } \\
\text { Verongida } \\
\text { Verticillitida }\end{array}$ \\
\hline & & & Tetractinomorpha & $\begin{array}{l}\text { Astrophorida } \\
\text { Chondrosida } \\
\text { Hadromerida } \\
\text { "Lithistids" } \\
\text { Spirophorida }\end{array}$ \\
\hline & & & Homoscleromorpha & Homosclerophida \\
\hline & & \multirow[t]{2}{*}{ Hexactinellida } & Hexasterophora & $\begin{array}{l}\text { Aulocalycoida } \\
\text { Hexaactinosida } \\
\text { Lychnicosida } \\
\text { Lyssacinosida }\end{array}$ \\
\hline & & & Amphodiscophora & Amphodiscosida \\
\hline & & \multirow[t]{2}{*}{ Calcarea } & Calcaronea & $\begin{array}{l}\text { Lithonida } \\
\text { Leucosolenida } \\
\text { Baerida }\end{array}$ \\
\hline & & & Calcinea & $\begin{array}{l}\text { Clathrinida } \\
\text { Murrayonida }\end{array}$ \\
\hline
\end{tabular}

\subsection{Tongan Marine Sponges and Chemistry}

Secondary metabolites isolated from tropical marine sponges are noted for their novelty and high chemical diversity, exhibiting a broad range of biological activities and unusual structures. The intense tropical coral reefs and warm waters comprise some of the densest and most diverse habitats for enormous numbers of organisms. As a result, the tropical sponges tend to use less energy through homeostasis due to the warmer waters in which they live, therefore they are able to devote more energy to producing biologically active compounds as chemical defenses. Additionally, the higher grazing pressure from many different predators enhanced the production of biologically active compounds.

The Kingdom of Tonga is an archipelago in the Central Indo-Pacific Ocean consisting of 176 islands ( 36 of which are inhabited). Tonga is located at latitude $20^{\circ} 0^{\prime} 0^{\prime \prime} \mathrm{S}$ and longitude $175^{\circ} 0^{\prime} 0^{\prime \prime} \mathrm{W}$ (Figure 1.1) and is divided into four main groups; Tongatapu, Vava'u, Ha'apai and 'Eua. The largest island, Tongatapu, on which the capital of 


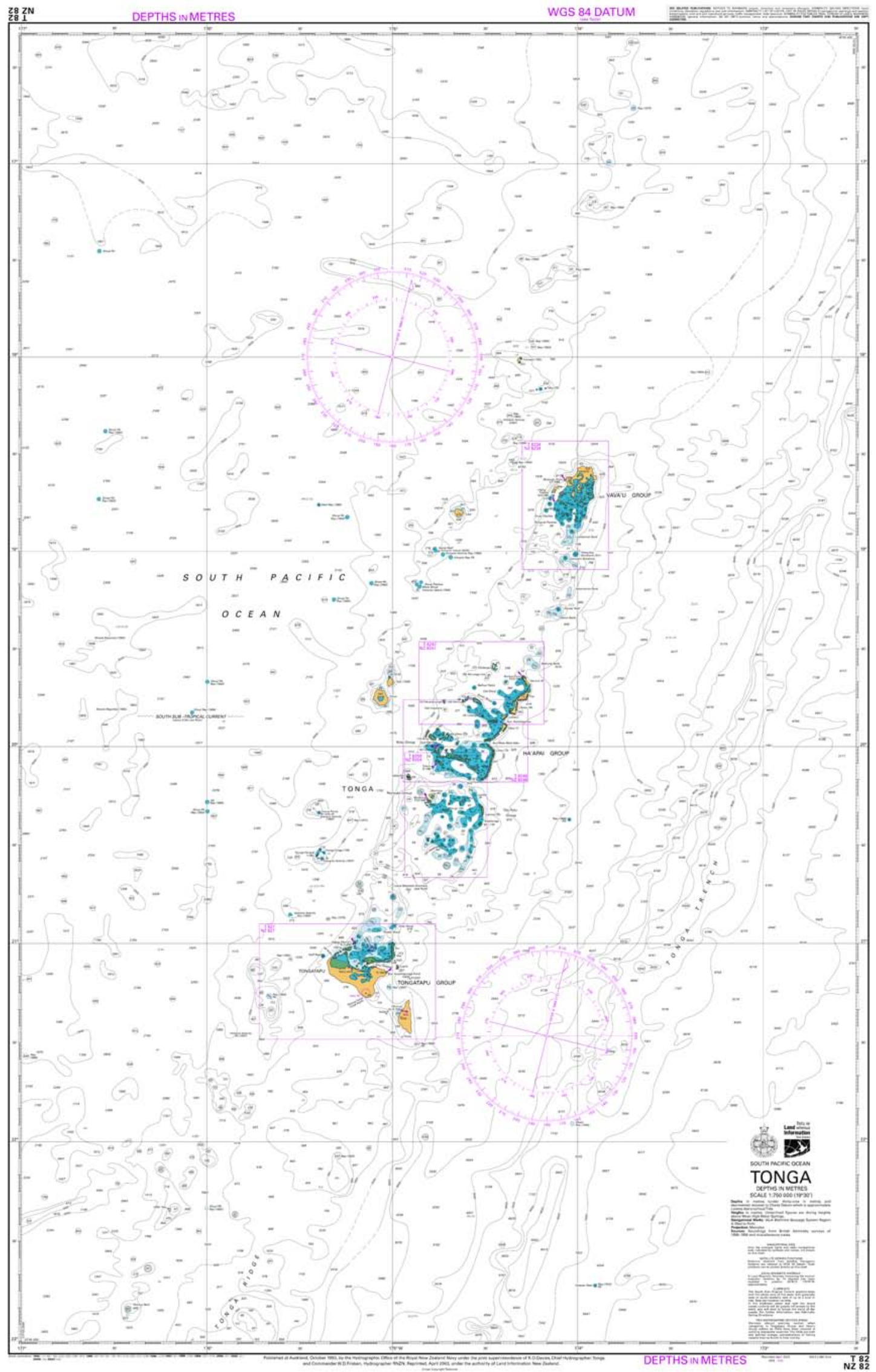

Figure 1.1. Map of the Kingdom of Tonga. Map courtesy of LINZ.

Nuku'alofa is located covers 257 square kilometres. Geologically the Tongan islands are of two types: most have a limestone base formed from uplifted coral formations; others 
consist of limestone overlaying a volcanic base. Due in part to its geographical central location at the meeting of two oceans (Indian and Pacific Oceans), Tongan waters have a distinct marine realm and comprise one of the greatest diversity of marine life. Tonga has a total land area of $688 \mathrm{sq} \mathrm{km}$ with Exclusive Economic Zone (EEZ) of 700,000 sq km, 1000 times more its land area, thus Tonga is an excellent place to study marine natural products.

There are few reports of marine natural products isolated from Tongan marine organisms, even though its marine environment offers an amazing and fascinating biodiversity. The first marine natural products research group to investigate the Tongan sponges was led by Phillip Crews from the University of California at Santa Cruz. Their collections were made in the early 1980s from Vava'u and the Ha'apai groups, located in northern Tonga.

The first novel compound reported from the Tongan marine environment was nuapapuin A methyl ester (13) (formerly known as methyl nuapauanoate) isolated together with the known norsesterterpene muqubilin (14). ${ }^{27,28}$ Compound 13 was obtained from a large soft drab sponge initially identified as Prianos sp., but revised to Diacarnus cf. spinopoculum, and is considered to be the first norditerpene isolated from a marine sponge. ${ }^{28,29}$ Nuapapuin A (13) demonstrated selective cytotoxicity against eight tumour cell lines in the soft agar assay, with $\mathrm{GI}_{50}$ values of less than $0.5 \mu \mathrm{M} .^{28}$ Interestly, the norditerpene peroxides clearly demonstrated superior profiles compared to the norsesterterpene peroxides. ${ }^{28}$ A study of the anti-flammatory active extracts from the sponge Hyrtios erecta revealed a novel scalarane norsesterterpenoid, hytrial (15). ${ }^{30}$ Hytrial (15) was re-isolated with a further five novel scalarane-type sesterterpenes (1620). ${ }^{31}$ Compound 15 has shown to decrease by $43 \%$ the weight of mouse ear oedema induced by PMA at a concentration of $c a .50 \mu \mathrm{g}$ per ear. ${ }^{31}$ Heteronemin acetate (17) was also cytotoxic against the human normal cell line (human oral fibroblasts) with an $\mathrm{IC}_{50}$ value of $16.09 \mu \mathrm{M}$. ${ }^{32}$ 12-Deacetyl-12-epi-scalaradial (16) and 17 showed antitubercular activity with MIC values of $63 \mu \mathrm{M}$ and $3 \mu \mathrm{M}$ respectively. ${ }^{32}$ It was suggested that the oxygenated pattern at C-24 and C-25 of the scalarane-type sesterterpenes might assert a strong influence on their resultant biological activities. ${ }^{31}$ 


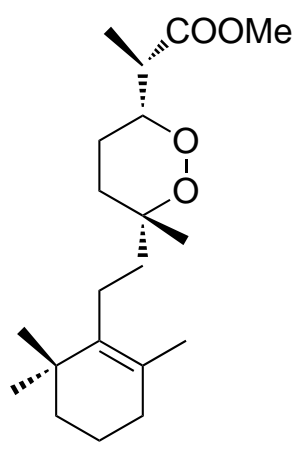

13

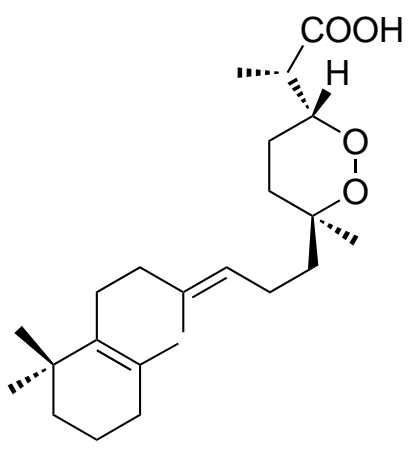

14
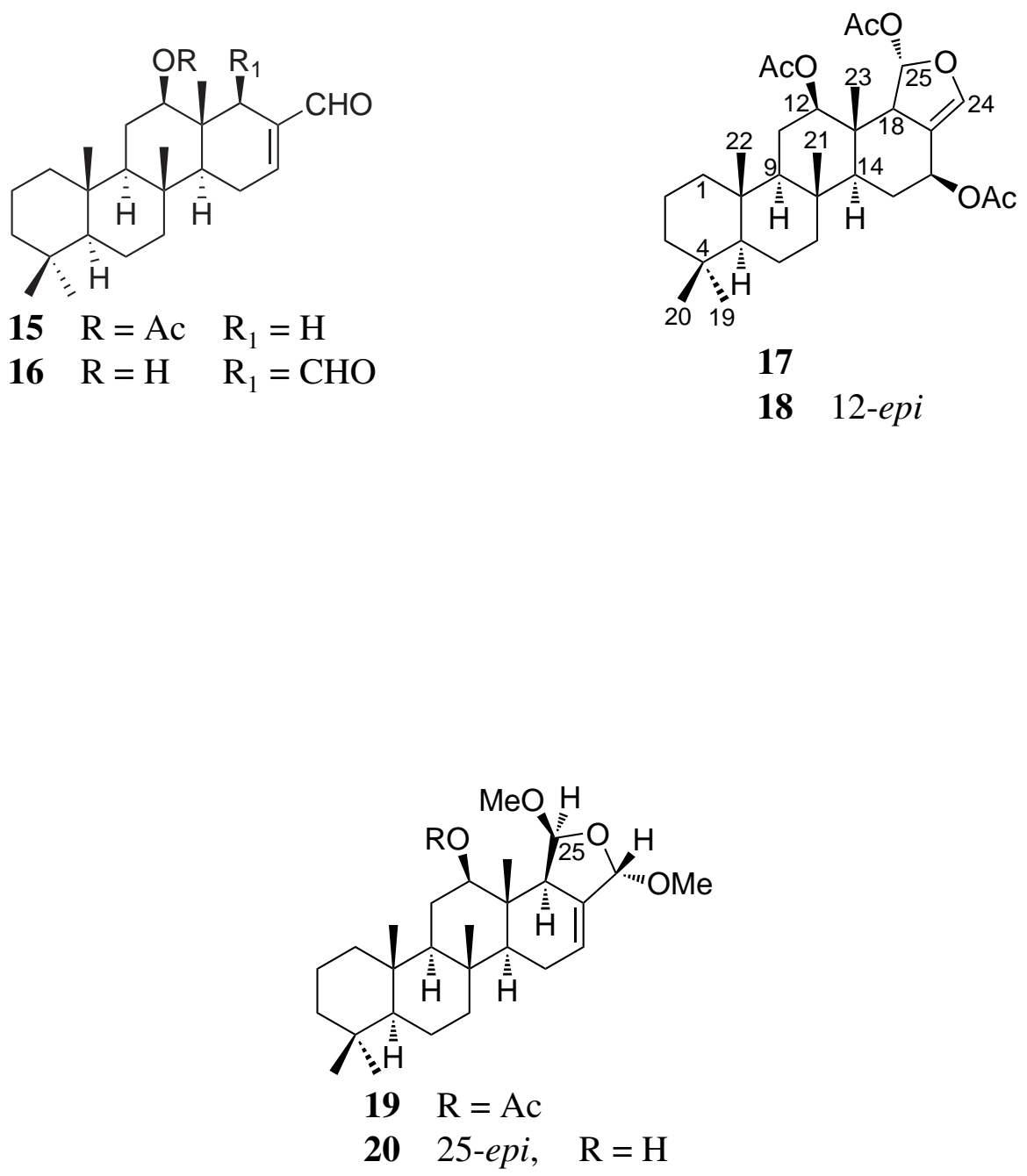
Psammaplin A (21) was reported in 1987 from the marine sponge Psammaplysilla sp., and is the first example of a disulfide derived from a marine sponge. ${ }^{33}$ In 2007, 20 years after the first report, there were 45 articles published based on the chemical study of 21. ${ }^{34}$ Compound 21 inhibits the activities of several key enzymes in prokaryotic and eukaryotic systems, including those involved in epigenetic control of gene expression, DNA replication, angiogenesis, microbial detoxification, and tumor cell growth. ${ }^{35-44}$ Three novel isomalabaricane triterpenes (22-24) were obtained from the organic extract of the specimen of Japsis sp. collected near Tonga, along with known triterpene 3-epi29-hydroxystelliferin E (25). ${ }^{45}$ As isomalabaricane triterpenes are known to isomerise upon exposure to light, the isomeric mixtures of the four compounds were tested against melanoma (MALME-3M) and leukemia (MOLT-4) cell lines. Against MALME-3M cell line the mixtures of 29-hydroxystelliferin A (23)/29-hydroxystelliferin B (26) and stelliferin $\mathrm{G}(\mathbf{2 4}) / 13 E$-stelliferin $\mathrm{G}$ (27) were the most growth-inhibitory $\left(\mathrm{IC}_{50}\right.$ values of 0.11 and $0.23, \mu \mathrm{g} / \mathrm{mL}$ respectively). ${ }^{45}$ The other two mixtures, 29-hydroxystelliferin $\mathrm{E}$ (22)/13E-29-hydroxystelliferin E (28) and 3-epi-29-hydroxystelliferin E (25)/13E-3-epi29-hydroxystelliferin E (29), were approximately 10-fold less potent with a similar trend observed with the MOLT-4 results.<smiles>O=C(NCCSSCCNC(=O)/C(Cc1ccc(O)c(Br)c1)=N/O)/C(Cc1ccc(O)c(Br)c1)=N/O</smiles>
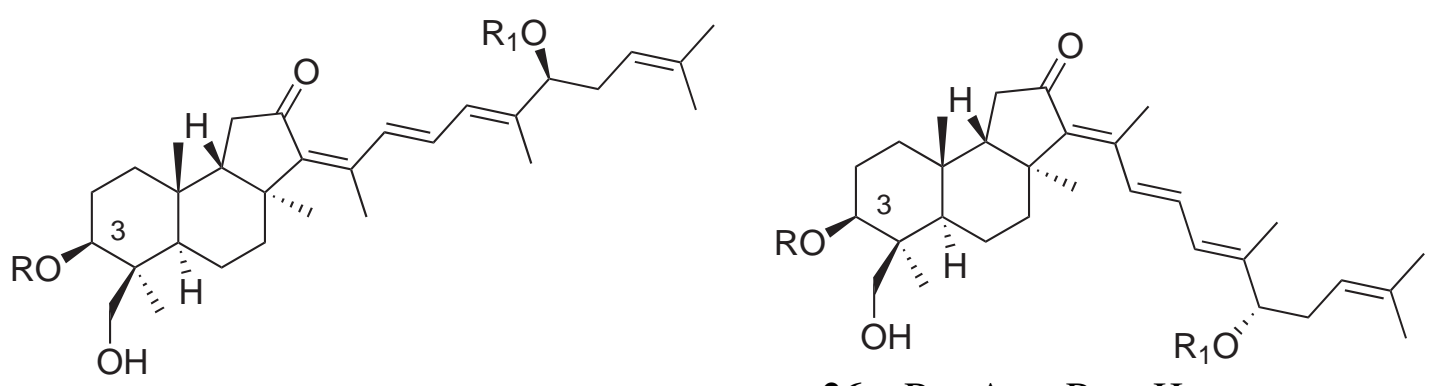

$$
\begin{array}{llll}
\mathbf{2 2} & \mathrm{R}=\mathrm{Ac} & \mathrm{R}_{1}=\mathrm{Ac} & \\
\mathbf{2 3} & \mathrm{R}=\mathrm{Ac} & \mathrm{R}_{1}=\mathrm{H} & \\
\mathbf{2 4} & 3-e p i, & \mathrm{R}=\mathrm{H} & \mathrm{R}_{1}=\mathrm{Ac} \\
\mathbf{2 5} & 3-\text {-epi, } & \mathrm{R}=\mathrm{Ac} & \mathrm{R}_{1}=\mathrm{Ac}
\end{array}
$$

$26 \mathrm{R}=\mathrm{Ac} \quad \mathrm{R}_{1}=\mathrm{H}$

27 3-epi, $\mathrm{R}=\mathrm{Ac} \quad \mathrm{R}_{1}=\mathrm{Ac}$

$28 \mathrm{R}=\mathrm{Ac} \quad \mathrm{R}_{1}=\mathrm{Ac}$

29 3-ерi, $\mathrm{R}=\mathrm{H} \quad \mathrm{R}_{1}=\mathrm{Ac}$

The paucity of investigation and analysis on Tongan marine fauna and the promising 
results mentioned above suggested that more research should be carried out on Tongan marine organisms. To date, there are no reported marine natural products isolated from Tongan marine organisms other than sponges. For the last two years, the Marine Natural Products group at Victoria University of Wellington (VUW) has shifted their research and attention from New Zealand marine organisms to the tropical Pacific marine environment of Tonga. Recent results include the re-isolation of zampanolide (30), a potent 20-membered macrolide from the Tongan marine sponge Cacospongia mycofijiensis. ${ }^{46}$ Although compound $\mathbf{3 0}$ was originally reported from the Japanese marine sponge Fasciospongia rimosa, and exhibited potent cytotoxicity against several cell lines ( $\left.\mathrm{IC}_{50} 1-5 \mathrm{ng} / \mathrm{mL}\right)$, there was no information available on the mode of action. ${ }^{47}$ The recent isolation of $\mathbf{3 0}$ allowed further investigation on its mode of action, which proved to be a novel and potent microtubule-stablising compound. This places zampanolide (30) in an important group of anti-cancer compounds that includes the clinically valuable paclitaxel (31), docetaxel (32), ixabepilone (azaepothilone B, 33); and a number of other potent microtubule-stabilising agents, including laulimalide (34), peloruside A (35), discodermolide (36), and dictyostatin (37). ${ }^{48,49}$ Zampanolide (30) is cytotoxic in nanomolar concentrations by arresting cells in the $\mathrm{G}_{2} \mathrm{M}$ phase of the cell cycle by polymerising microtubules. ${ }^{46,50}$ Further examination of $C$. mycofijiensis generated a number of known bioactive compounds, including laulimalide (34) and isolaulimalide (38) (both are microtubule-stabilising agents), latrunculin A (an actin-destabilising agent, 39), dendrolasin (having pheromonal activity, 40), and mycothiazole (41). ${ }^{50}$<smiles>C=C1C[C@H](C)O[C@@H](C/C=C/C(=O)C/C(C)=C\C=C\C(=O)OC(C/C(C)=C/[C@H]2CC(=C)C/C(=C\C=C/C=C/C)O2)C(O)NC(=O)/C=C/C)C1</smiles>

30

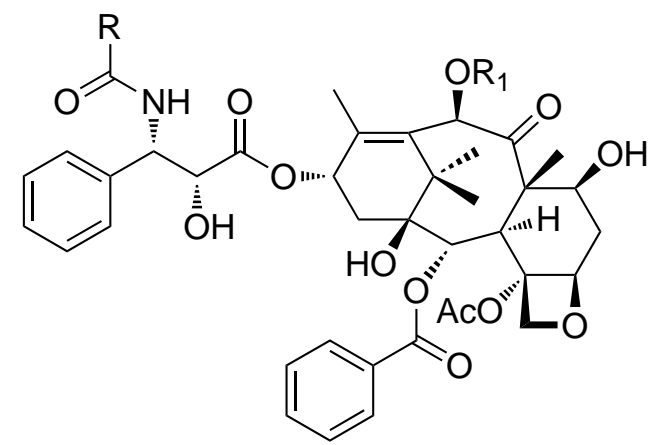

$31 \mathrm{R}=\mathrm{Ph} \quad \mathrm{R}_{1}=\mathrm{Ac}$

$32 \mathrm{R}=(\mathrm{Me})_{3} \mathrm{O} \quad \mathrm{R}_{1}=\mathrm{H}$ 


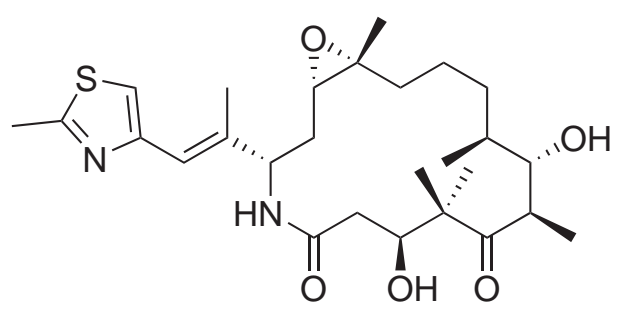

33

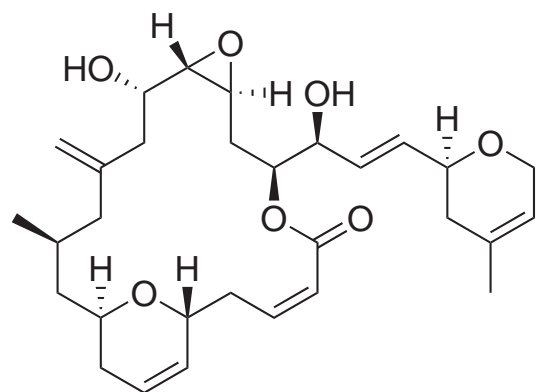

34

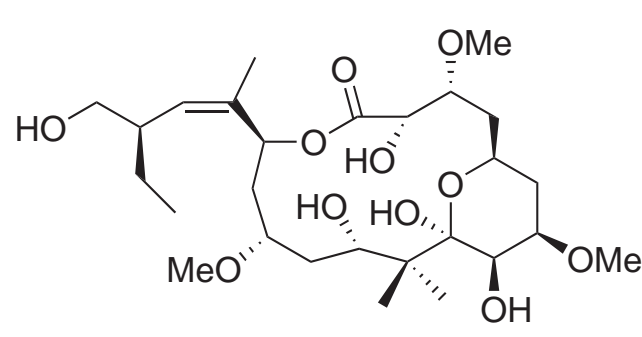

35

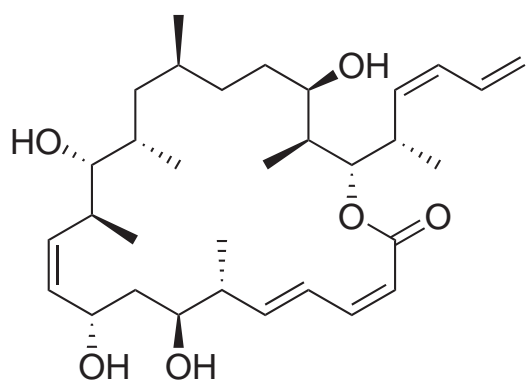

37

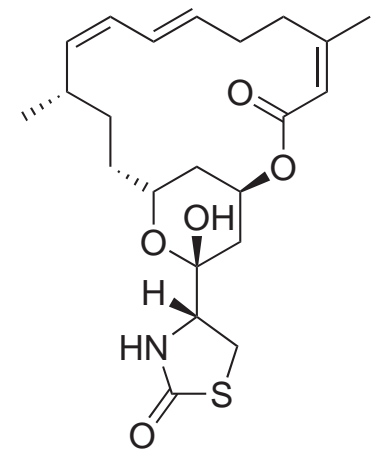

39

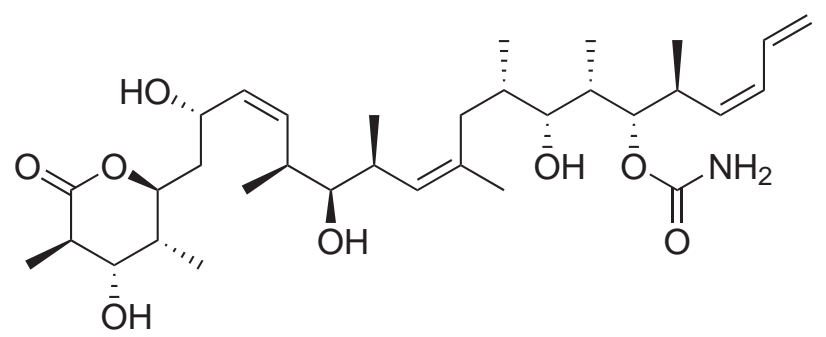

36

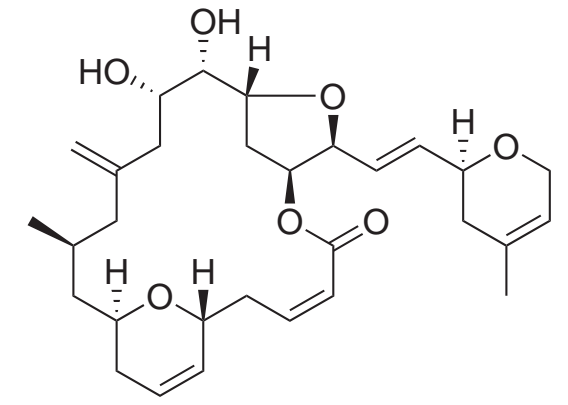

38

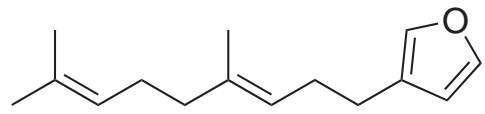

40<smiles>C=CC/C=C/Cc1csc(C(C)(C)[C@H](O)C/C=C\C(=C)CCNC(=O)OC)n1</smiles> 


\section{Chapter 2}

\section{Isolation and Screening of Secondary Metabolites}

\subsection{Isolation Techniques}

The goal of the Marine Natural Products Group at VUW is to isolate novel chemical structures with interesting and useful biological activities, utilising novel techniques. These include a chromatographic method, cyclic loading, as well as NMR-based screening methods, which are discussed below.

\subsubsection{Cyclic Loading}

For biological activity of secondary metabolites to be effective, the structure must possess a mixture of both hydrophilic and hydrophobic properties that enables them to be easily transported across cell membranes and other biological barriers. ${ }^{51}$ The crude extracts of sponges contain a wide range of compounds with varying degrees of polarity, ranging from polar amino acids, salts and sugars to non-polar fats, lipids and steroids. This can be best described in terms of a "mass window" (Figure 2.1), where the intermediate region (lowest relative mass, mid-polarity) contains few primary metabolites, making the mass window an ideal target for the first stage of fractionation of a crude extract.

The Marine Natural Products group at VUW has developed a technique known as "cyclic loading". 52 This reversed-phase chromatographic technique utilises poly(styrenedivinylbenzene) (PSDVB), as the stationary phase. The resin is an inexpensive, chemically inert, crosslinked polymeric resin, that is highly porous, lacks polar sites, and is stable over a large $\mathrm{pH}$ range. ${ }^{53}$ These characteristics contribute to the repeated use of PSDVB without any significant decrease in performance. The first stage of cyclic loading involves passing the extract(s) through the column. This allows most of the non-polar compounds in the extracts to adhere to the PSDVB beads. The eluent is then diluted 
with $\mathrm{H}_{2} \mathrm{O}$ and passed back through the column. Under the normal circumtances, addition of $\mathrm{H}_{2} \mathrm{O}$ to a crude extract would result in the precipitation of the non-polar compounds, which is avoided during cyclic loading, as the most non-polar fats and triglycerides have adsorbed to the column during the first pass. As the eluent is gradually made more polar by each dilution with $\mathrm{H}_{2} \mathrm{O}$, the more polar compounds in the extract are adsorbed to the column. The cyclic process is repeated until all the compounds of interest are adhered to the PSDVB beads in the column.

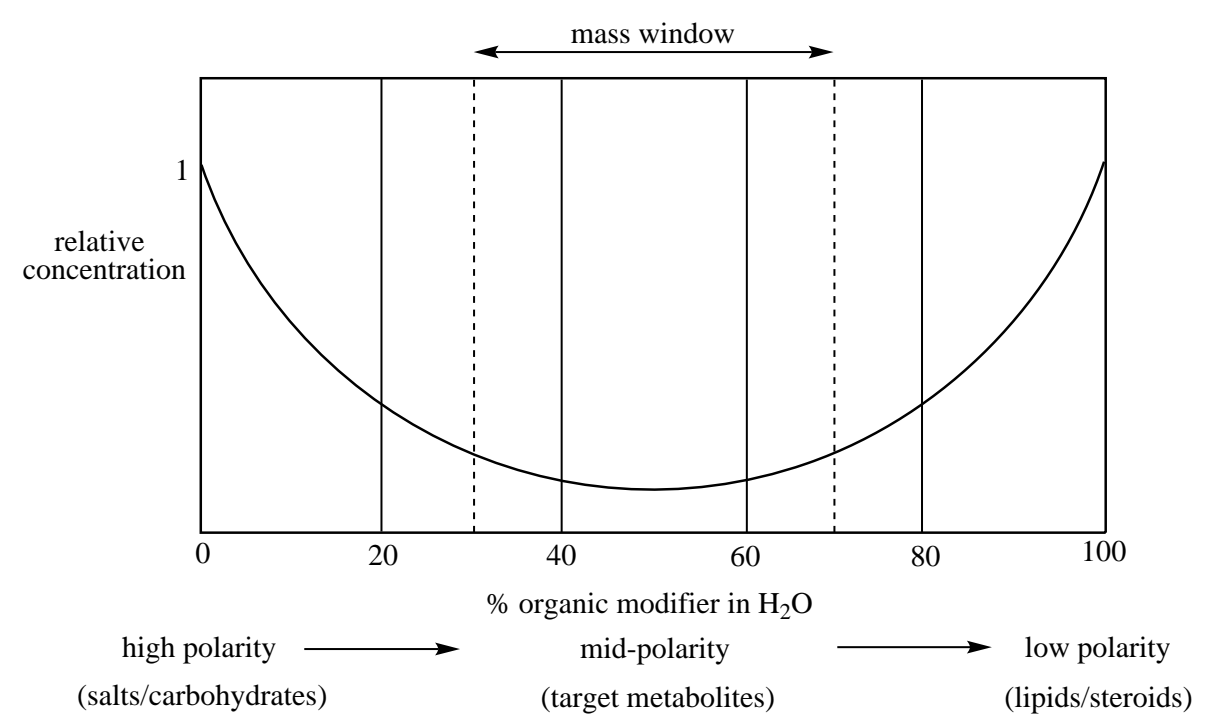

Figure 2.1. Schematic of the mass distribution in a typical marine sponge extract.

Once the crude sponge extracts are retained in the column, it is washed with distilled $\mathrm{H}_{2} \mathrm{O}$ to remove any remaining salts. The loaded column then can be sequentially eluted with a gradient of increasing organic modifier $\left(\mathrm{Me}_{2} \mathrm{CO}\right.$ or $\left.\mathrm{MeOH}\right) / \mathrm{H}_{2} \mathrm{O}$ to obtain a number of fractions of decreasing polarity. During the elution process, the earlier fractions usually contain mostly highly polar materials such as amino acids and sugars. The non-polar materials such as lipids and steroids usually come off in the later fractions. The midpolarity materials that contain most of the interesting secondary metabolites are eluted in the middle fractions (with few exceptions). The fractions obtained from cyclic loading contain varying amounts of $\mathrm{H}_{2} \mathrm{O}$, which is a major problem if the fraction must be concentrated under vacuum or reduced pressure. This problem is overcome by using a modified cyclic loading method called "back loading". The fractions containing water are further diluted with $\mathrm{H}_{2} \mathrm{O}$ and cyclic loaded back through the column. The column is then eluted with pure organic solvent $\left(\mathrm{Me}_{2} \mathrm{CO}\right.$ or $\left.\mathrm{MeOH}\right)$, creating a fraction with almost no water that can be concentrated under reduced pressure more easily. 


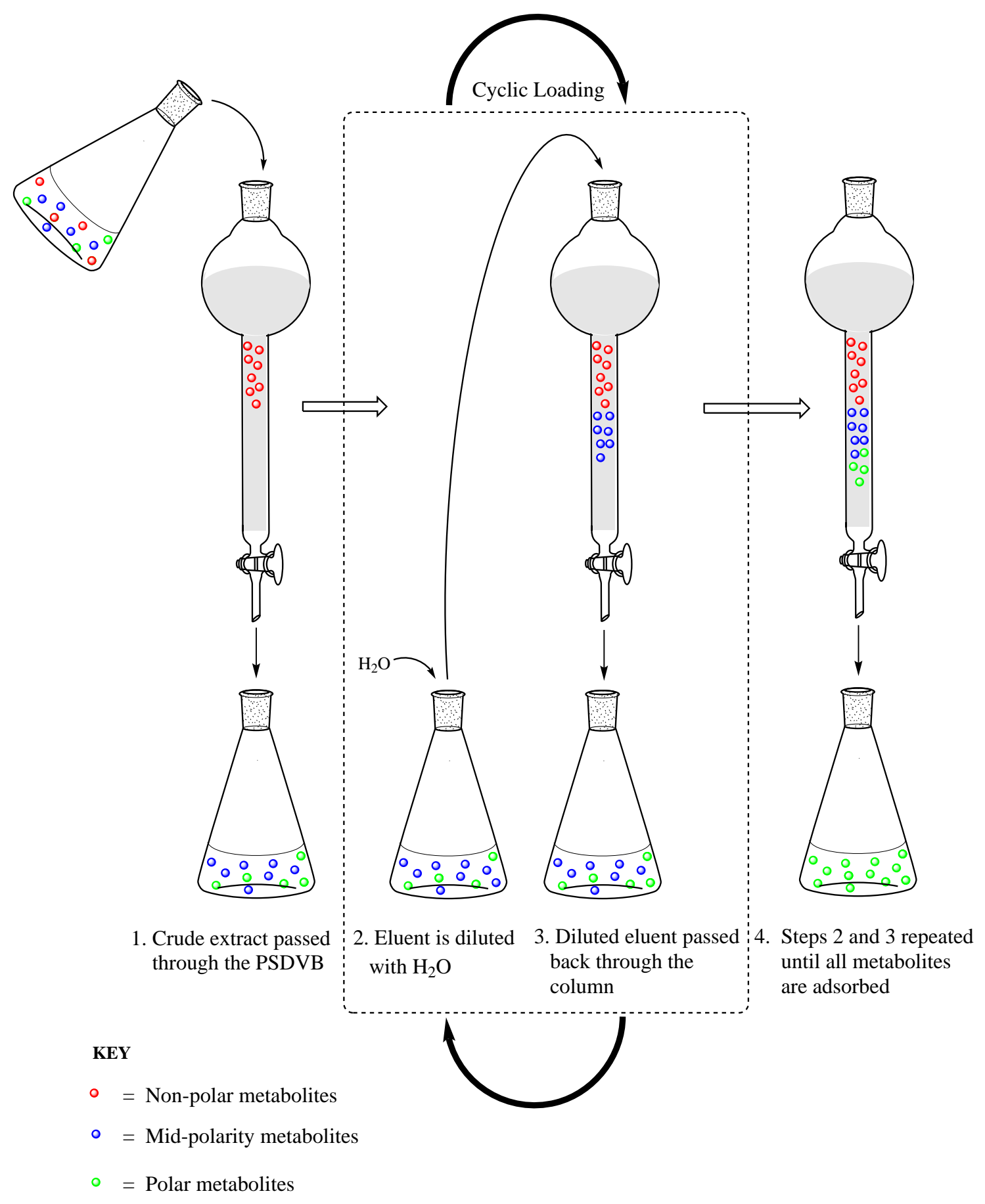

Figure 2.2. Schematic of the cyclic loading process.

\subsection{Screening of Marine Organisms}

\subsubsection{Bioassay-Directed Screening}

Bioassay (biological assay) directed isolation is the most common technique used for identifying novel and biologically active secondary metabolites from crude extracts. The main goal of a bioassay is to find and identify a biologically active compound. Extracts 
with any biological activity are iteratively fractionated and subjected to the same assay until the pure compound(s) is isolated. The major advantage of this method is the isolation of a pharmaceutically active secondary metabolite and maybe novel activity against the chosen target. However, the large number of fractions to be assayed is time consuming and often costly. Additionally, the activity of lower concentration metabolites can be masked by a higher concentration metabolite since an organism can produce numerous biologically active compounds.

\subsubsection{NMR-Based Screening}

In the case of NMR-based screening, the main goal is to find and isolate novel secondary metabolites and then investigate their biologically activity after isolation. Secondary metabolites have a biological function and therefore they may have medical and pharmaceutical application. This spectroscopy-directed isolation technique employs NMR spectroscopy as a guide for the isolation and identifies the interesting compounds. The advantages of this technique is that it is applicable to the isolation of most secondary metabolites. It has a good response factor and potential for vast structural information content. However, a solubility issue is a major problem due to larger range of polarities present in the crude extracts. This problem is overcome by using cyclic loading as the primary partition stage after extraction.

\subsection{VUW Screening Methodology}

The VUW Marine Natural Products Group has developed a NMR-based screening protocol for screening marine sponges and guiding the isolation procedure. Generally, for screening a typical New Zealand sponge, about $100 \mathrm{~g}$ of sponge is extracted twice with $\mathrm{MeOH}$. For a Tongan sponge, approximately $25 \mathrm{~g}$ is required due to the fact that tropical sponges are richer in chemical contents (smaller amount of sponges are collected as well). The extracts are then cyclic loaded onto a PSDVB column and then the column is desalted with distilled $\mathrm{H}_{2} \mathrm{O}$. The loaded column is then sequentially eluted with $30 \%$, 
$75 \% \mathrm{Me}_{2} \mathrm{CO} / \mathrm{H}_{2} \mathrm{O}$ and $100 \% \mathrm{Me}_{2} \mathrm{CO}$. The biologically active secondary metabolites tend to elute in the intermediate region, the $75 \% \mathrm{Me}_{2} \mathrm{CO} / \mathrm{H}_{2} \mathrm{O}$ fraction.

The idea behind the NMR-based screening protocol is to analyse the $75 \% \mathrm{Me}_{2} \mathrm{CO} / \mathrm{H}_{2} \mathrm{O}$ fraction by differentiating between common and unusual resonances present in the NMR spectra of semi-purified extracts. This simple screening technique resulted in the isolation of biologically active compounds such as peloruside A (35) and B (42), among others. ${ }^{52,53}$ However, the presence of primary metabolites conceals a large portion of the ${ }^{1} \mathrm{H}$ NMR spectrum, limiting the amount of structural information available. As a result, 2D NMR experiments (COSY, HSQC, and HMBC) have been used as a screening tool, since 2D NMR spectroscopy offers more detailed structural information, and a great advantage in the detection of novel secondary metabolites.

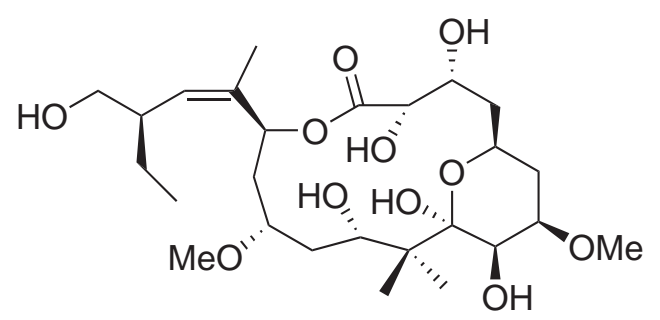

42

\subsubsection{HSQC Mask}

Initially, the COSY experiment was used as a screening tool, but it was deemed too complicated to be readily converted to a database form, so HSQC spectra with their relatively simple ${ }^{1} \mathrm{H}-{ }^{13} \mathrm{C}$ correlation data were chosen. ${ }^{54}$ In addition, the HSQC experiment provided more functional information in the carbon dimension. To construct the electronic mask, the HSQC data of the $75 \% \mathrm{Me}_{2} \mathrm{CO} / \mathrm{H}_{2} \mathrm{O}$ screen fractions are added together to generate a digital mask. For any given screen, the HSQC spectrum is compared to the mask where common signals (green peaks) are distinguished from those that are interesting. Correlations that are frequently observed are from compounds that are common amongst the screened sponges and are therefore likely to be primary or known metabolite(s). Thus, uncommon correlations (red peaks) may indicate the presence of novel secondary metabolite(s). The intensity of a particular correlation also indicates the 
relative amount of the compound present in the sponge. This current screen has been used in the isolation of new secondary metabolites from sponges and also adapted for red algae screening. ${ }^{54-57}$ Unfornately, this screening method is based only on New Zealand marine organisms and has not been applied to Tongan specimens, which is a major problem during the course of this study, which led to isolation of compounds already known from the literature.

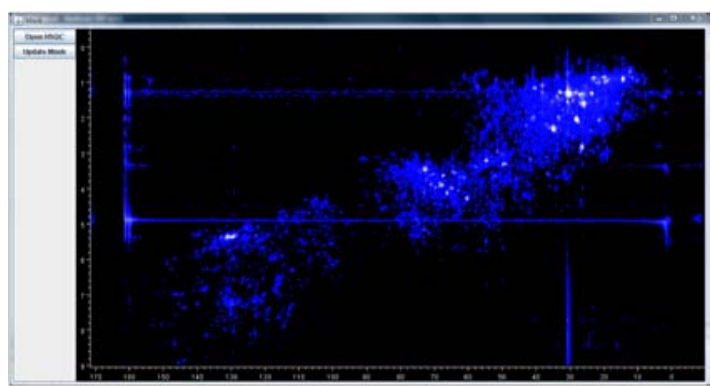

(a)

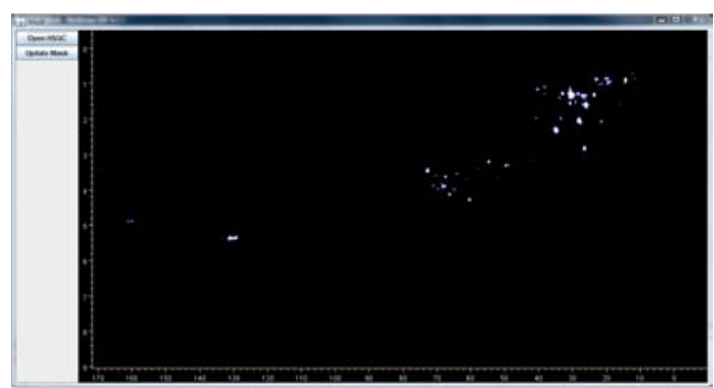

(b)

Figure 2.3. (a) Computer generated mask of HSQC data (contains 160 sponges). (b) Common correlations in the HSQC masks.

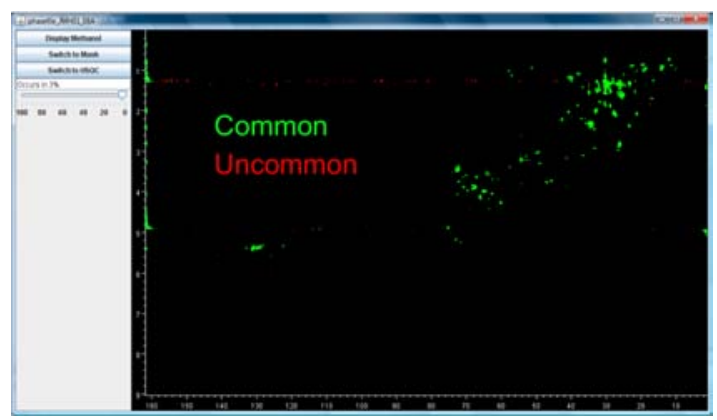

(a)

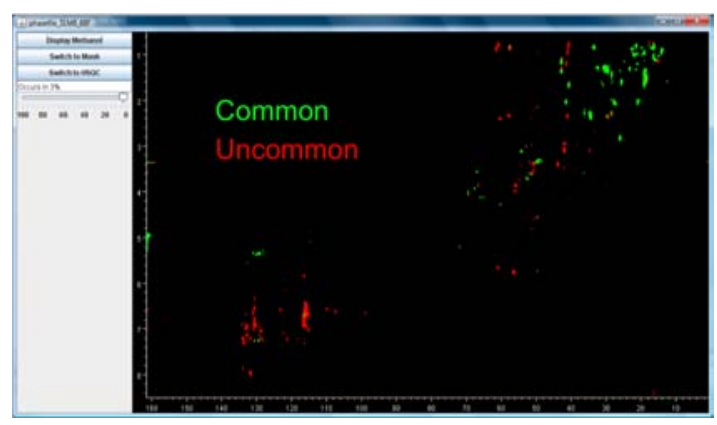

(b)

Figure 2.4. (a) An uninteresting sponge screen. (b) An interesting screen.

\subsection{Future Screening Methods}

The HSQC screen has been successful in reducing the volume of extraneous information which is presented to the analyst by masking out correlations in HSQC spectra which are of little or no interest due to their repeated occurrence in extracts. At the same time, this computer-based NMR screen has its limitations. Firstly, the non-protonated functional groups are not taken into account; for example carbonyl carbons (except aldehydes), non-protonated olefinic carbons, nitriles, imines, and $s p^{3}$ quaternary carbons. Secondly, the selection of the ${ }^{1} J_{\mathrm{CH}}$ value dictates which correlations appear most intense. Since 
${ }^{1} J_{\mathrm{CH}}$ ranges from about 110 to $320 \mathrm{~Hz}$, the current HSQC screen has a optimum ${ }^{1} J_{\mathrm{CH}}$ value of $140 \mathrm{~Hz}$, which allows ${ }^{1} J_{\mathrm{CH}}$ values between $110-170 \mathrm{~Hz}$ to appear with the highest intensity. Therefore, functional groups with ${ }^{1} J_{\mathrm{CH}}$ values outside this range appear proportionally weaker or missing unless the optimum value is changed.

\subsubsection{HMBC Screen}

An additonal screen based on the HMBC experiment is currently being developed in a similar manner to the HSQC screen. As the HSQC experiment correlates ${ }^{13} \mathrm{C}$ nuclei with directly attached ${ }^{1} \mathrm{H}$ only, the HMBC experiment offers multiple-bond correlations between ${ }^{1} \mathrm{H}$ and ${ }^{13} \mathrm{C}$ nuclei $\left({ }^{1} \mathrm{H}-{ }^{15} \mathrm{~N}\right.$ HMBC is also utilised) thus providing more information, especially in the carbon dimension. The experiment can be performed concurrently with the HSQC screen experiment (mentioned before) and thus interesting one-bond correlations in the HSQC screen can be extended to multiple-bond correlations from the HMBC screen. An HMBC screen would potentially be an extremely powerful technique at an early stage of purification and this would help decide if a sponge extract is worthy of further investigation without fully committing to the purification process. 


\section{Chapter 3}

\section{Sponges Investigated by Spectroscopic Screening}

During the course of this study, two collection trips were made to Tonga. The first collection trip was to Tongatapu and 'Eua in late 2008 and the second was to the Vava'u Group in late 2009 (Figure 1.1). A total of 17 marine sponges were screened using the VUW method. Several sponges were selected for investigation based on their promising results in the 2D NMR spectra screening method, which led to isolation of novel and known compounds which are detailed in the following chapters.

\subsection{Sponges Screened from Tongatapu and 'Eua}

PTN3_13A

PTN3_13A is a very soft, unidentified orange coloured sponge (940 g) collected by snorkel from the Popua shoreline, near the capital Nuku'alofa, Tongatapu, Tonga. The sponge (22 g) was screened and the screen spectra contained resonances attributed to aromatics and evidence of peptides observed in HMBC spectrum. A second, large-scale bulk extraction of the sponge ( $329 \mathrm{~g}$ ) was performed. Subsequent analysis of this extract showed no evidence of the interesting resonances and solubility issues with the NMR solvents were encountered. No further analysis was performed.

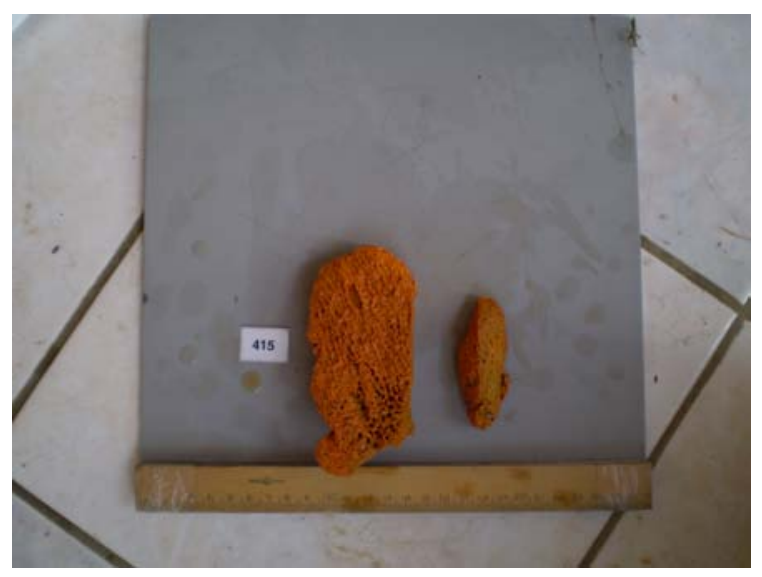

Figure 3.1. Surface photo of the PTN3_13A sponge. 
PTN3_13C is an unidentified sponge (833 g) collected from the front coast of Popua near the capital Nuku'alofa, Tongatapu, Tonga. $23 \mathrm{~g}$ of the sponge was screened. The screen spectra of the $75 \% \mathrm{Me}_{2} \mathrm{CO} / \mathrm{H}_{2} \mathrm{O}$ fraction contained non-interesting resonances. Further purification and analysis was automatically discontinued.

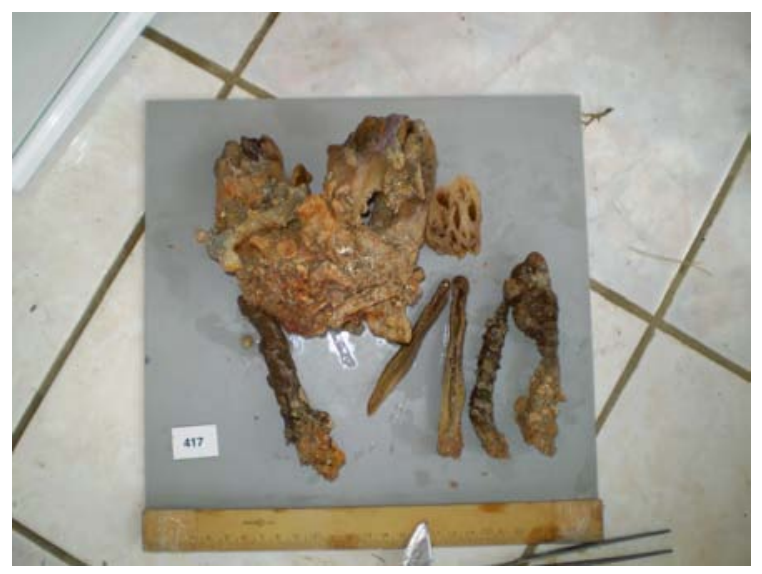

Figure 3.2. Surface photo of the PTN3_13C sponge.

\section{PTN3_14B}

PTN3_14B is ann unidentified yellow coloured, finger sponge (130 g) from 'Ohonua Harbour, 'Eua, Tonga. The screen spectra of the $75 \% \mathrm{Me}_{2} \mathrm{CO} / \mathrm{H}_{2} \mathrm{O}$ fraction contained a number of resonances largely attributed to aromatics. No further analysis was performed.

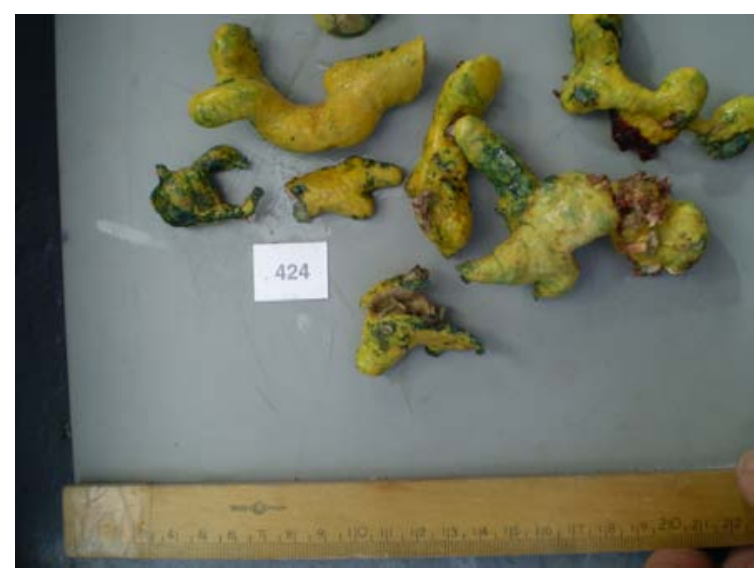

Figure 3.3. Surface photo of the PTN3_14B sponge. 


\section{PTN3_14E}

PTN3_14E is an unidentified sponge (104 g) collected from 'Ohonua Harbour, 'Eua, Tonga. With $22 \mathrm{~g}$ of the sponge being screened, the screen spectra contained resonances attributed to aromatics, oxymethylene and oxymethine regions. Due to encountering solubility issues with the NMR solvents, no further analysis was performed.

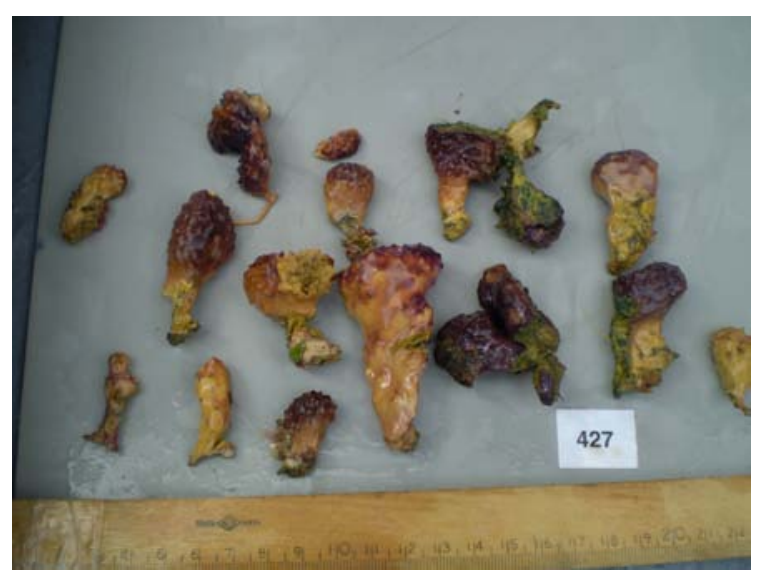

Figure 3.4. Surface photo of the PTN3_14E sponge.

\section{PTN3_14F}

PTN3_14F is an unidentified sponge (274 g) collected from 'Ohonua Harbour, 'Eua, Tonga. $24 \mathrm{~g}$ of the sponge was screened and the screen spectra contained resonances largely attributed to terpenoids with great similarity to that of PTN3_19A and PTN3_22B. Therefore, further purification and analysis was discontinued.

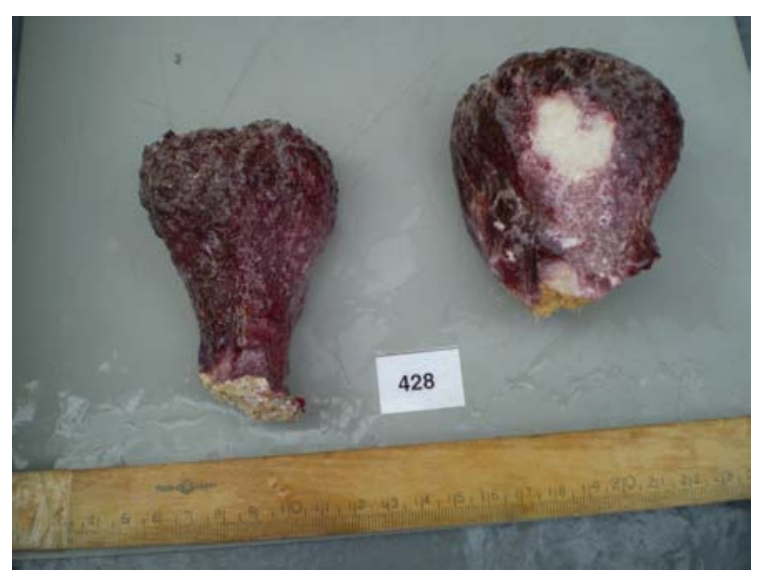

Figure 3.5. Surface photo of the PTN3_14F sponge. 


\section{PTN3_15C}

PTN3_15C is a leathery grey unidentified sponge (525 g) collected from the coastline of Houma, 'Eua, Tonga. A $23 \mathrm{~g}$ of the sponge was screened. The screen spectra of the $75 \% \mathrm{Me}_{2} \mathrm{CO} / \mathrm{H}_{2} \mathrm{O}$ fraction contained resonances attributed to aromatics, olefinic and oxymethine regions. Further purification and analysis was discontinued.

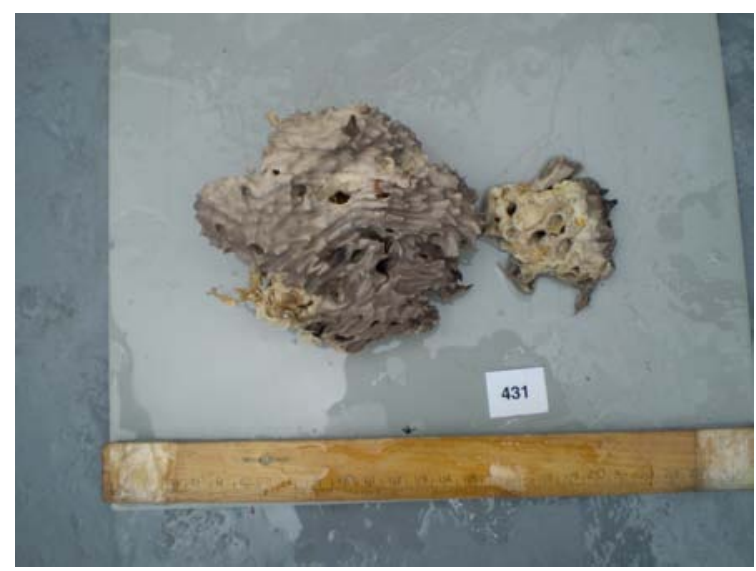

Figure 3.6. Surface photo of the PTN3_15C sponge.

\section{PTN3_16F}

PTN3_16F is an unidentified yellowed coloured, rubble-like sponge $(150 \mathrm{~g})$ from the coastline of Houma, 'Eua, Tonga. $23 \mathrm{~g}$ of the sponge was screened and the screen spectra of the $75 \% \mathrm{Me}_{2} \mathrm{CO} / \mathrm{H}_{2} \mathrm{O}$ fraction contained resonances largely attributed to oxymethine, oxymethylene, and oxymethyl regions with few in the aromatic region. Further purification and analysis was discontinued.

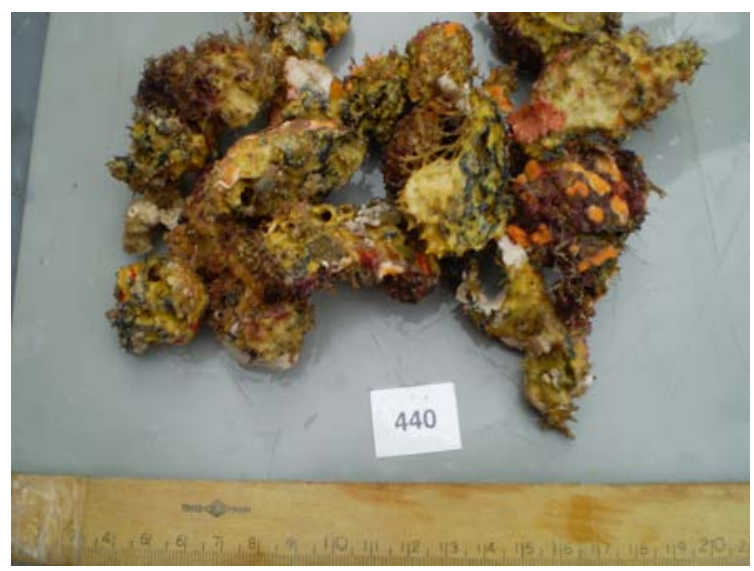

Figure 3.7. Surface photo of the PTN3_16F sponge. 


\section{PTN3_18C}

PTN3_18C is an unidentified grey dictyoceratid sponge (21 g) collected from the coast of Houma, 'Eua, Tonga. The screen spectra of the $75 \% \mathrm{Me}_{2} \mathrm{CO} / \mathrm{H}_{2} \mathrm{O}$ contained resonances attributed to aromatics, oxymethyls and oxymethines. No further analysis was perfomed.

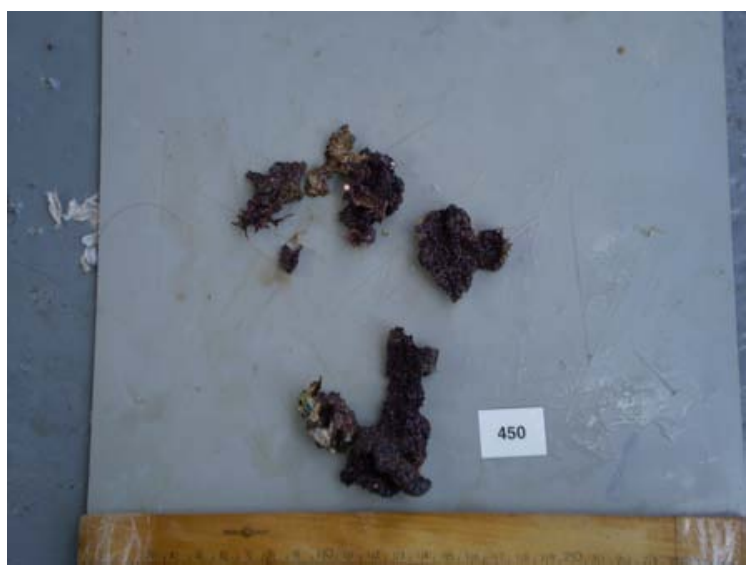

Figure 3.8. Surface photo of the PTN3_18C sponge.

\section{PTN3_19A and PTN3_22B}

PTN3_19A and PTN3_22B were an unidentified sponges (250 g), reddish-coloured of the genus Fascaplysinopsis were collected from an underwater cave in southwestern 'Eua, Tonga, with only $25 \mathrm{~g}$ of the sponges screened. The screen spectra of the $75 \%$ $\mathrm{Me}_{2} \mathrm{CO} / \mathrm{H}_{2} \mathrm{O}$ fraction contained resonances largely attributed to aromatics and terpenoids. A second, large-scale bulk extraction of the sponge (200 g) was performed. Purification and analysis of the bulk extracts led to isolation of the three known compounds homofascaplysin A (43), isodehydroluffariellolide (44) and luffariellolide (45), along with two novel sestertepenes, isoluffariellolide (46) and 1-O-methylisoluffariellolide (47). Isolation and the structure elucidation of the two novel sesterterpenes (46-47) will be discussed in Chapter 5.

\section{PTN3_21C}

PTN3 21C is an unidentified sponge (350 g) from the order Dictyoceratida collected from an underwater cave in southwestern 'Eua, Tonga. Only $26 \mathrm{~g}$ of the sponge was originally screened. The screen spectra of the $75 \% \mathrm{Me}_{2} \mathrm{CO} / \mathrm{H}_{2} \mathrm{O}$ fraction contained resonances largely attributed to terpenoids and sign of aldehydes. Further purification 
led to the isolation of the known sesterterpene thorectolide (48) and a novel sesterterpene, secothorectolide (49). The isolation and structural elucidation of secothorectolide (49) is dealt with in Chapter 6.

\section{PTN3_25E}

PTN3 25E is an unidentified orange coloured sponge (400 g) collected from Fāfā Island, located off the coast of Nuku'alofa, Tongatapu, Tonga. The sponge (22 g) was screened and the screen spectra contained resonances attributed to aromatics and evidence of peptides observed in the HMBC spectrum. It was concluded that it is the same sponge as PTN3_13A. No further analysis was performed.

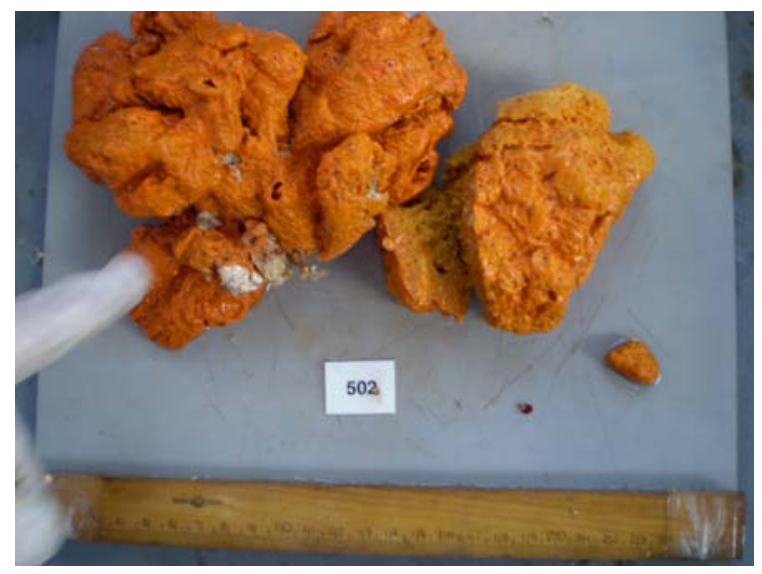

Figure 3.9. Surface photo of the PTN3_25E sponge.

\section{PTN3 25F}

PTN3_25F is an unidentified sponge (700 g) collected from Fāfā Island, located off the coast of Nuku'alofa, Tongatapu, Tonga. Only $23 \mathrm{~g}$ of the sponge was taken for screening. The screen spectra of the $75 \% \mathrm{Me}_{2} \mathrm{CO} / \mathrm{H}_{2} \mathrm{O}$ fraction contained resonances attributed to aromatics and oxymethylene regions. Further purification and anaysis was discontinued.

\subsection{Sponges Screened from the Vava'u Group}

PTN3 33F

PTN3_33F is an unidentified sponge (1989 $\mathrm{g}$ ) belong to the order Verongida was collected from Ano Beach, Vava' $\mathrm{u}$, Tonga by snorkel. $27 \mathrm{~g}$ was screened and the screen spectra of 


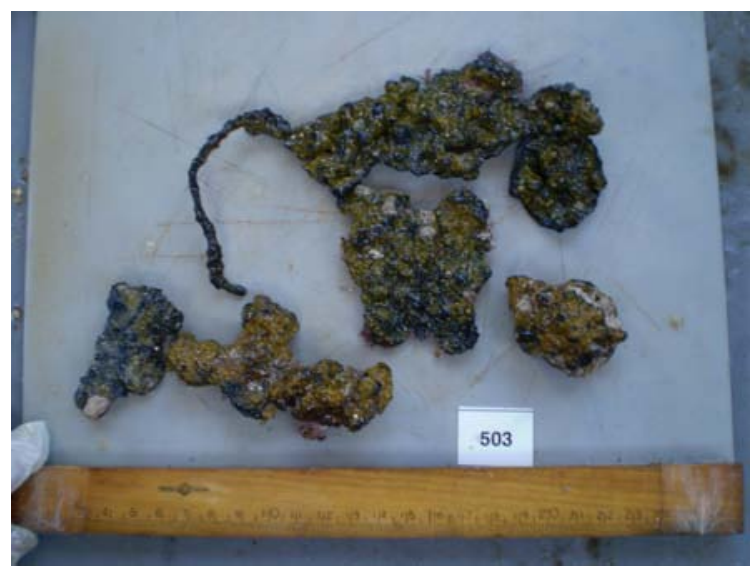

Figure 3.10. Surface photo of the PTN3_25F sponge.

the $75 \% \mathrm{Me}_{2} \mathrm{CO} / \mathrm{H}_{2} \mathrm{O}$ fraction contained resonances attributed to aromatics, oxymethine and oxymethyl regions. Further purification of this fraction led to the isolation of two known bromotyrosine alkaloid compounds aplysamine-2 (50) and aerophobin-1 (51). The isolation of compounds (50-51) will be discussed in Chapter 4.

\section{PTN3_45H}

PTN3_45H is a bright yellow calcareous sponge (825 g) of the genus Leucetta collected from an underwater cave from Tu'ungasika Island, Vava'u, Tonga. $21 \mathrm{~g}$ was taken for screening. The screen spectra of the $75 \% \mathrm{Me}_{2} \mathrm{CO} / \mathrm{H}_{2} \mathrm{O}$ fraction contained interesting resonances largely attributed to aromatics. Subsequent purification and analysis of the $75 \% \mathrm{Me}_{2} \mathrm{CO} / \mathrm{H}_{2} \mathrm{O}$ was discontinued and set aside due to the small sample and lack of time for large-scale extracts.

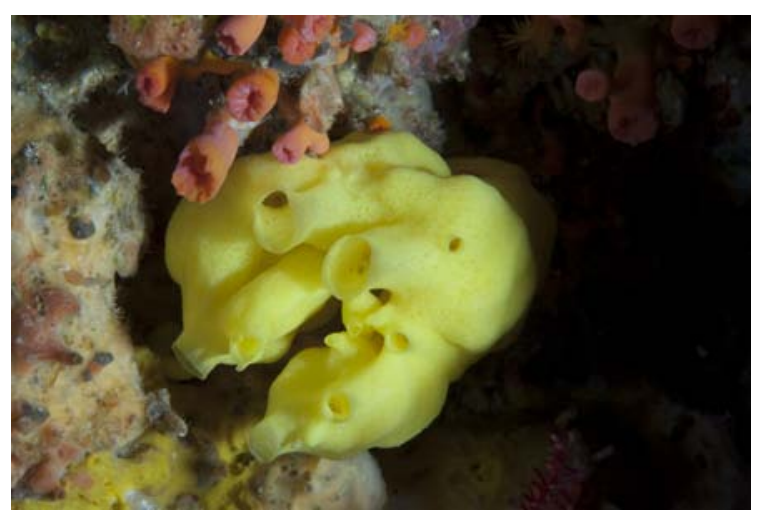

Figure 3.11. Underwater photo of the Leucetta sp. (courtesy of Karen Stone). 


\section{PTN3_46E}

PTN3_46E is an unidentified sponge (365 g) of the order Verongida, collected from Tu'ungasika Island, Vava'u, Tonga. The sponge (27 g) was extracted and the screen spectra of the $75 \% \mathrm{Me}_{2} \mathrm{CO} / \mathrm{H}_{2} \mathrm{O}$ contained resonances attributed to aromatics, oxymethine, oxymethylene, and oxymethyl regions. Further purification of this fraction led to isolation of three known bromotyrosine compounds fistularin-3 (52), aeroplysinin-1 (53) and LL-PAA216 (54), which will be discussed in Chapter 4.

\section{PTN4_05D}

PTN4_05D is an unidentified sponge (701 g) collected near Hunga, Vava ' $\mathrm{u}$, Tonga. The sponge (27 g) was selected for screening due to its similarity to genus Fascaplysinopsis (PTN3_19A collected from 'Eua). However, the screen spectra of the $75 \% \mathrm{Me}_{2} \mathrm{CO} / \mathrm{H}_{2} \mathrm{O}$ fraction contained resonances attributed to terpenoids and nothing in the aromatic regions (similar to PTN3_14F). Further purification and analysis was discontinued.

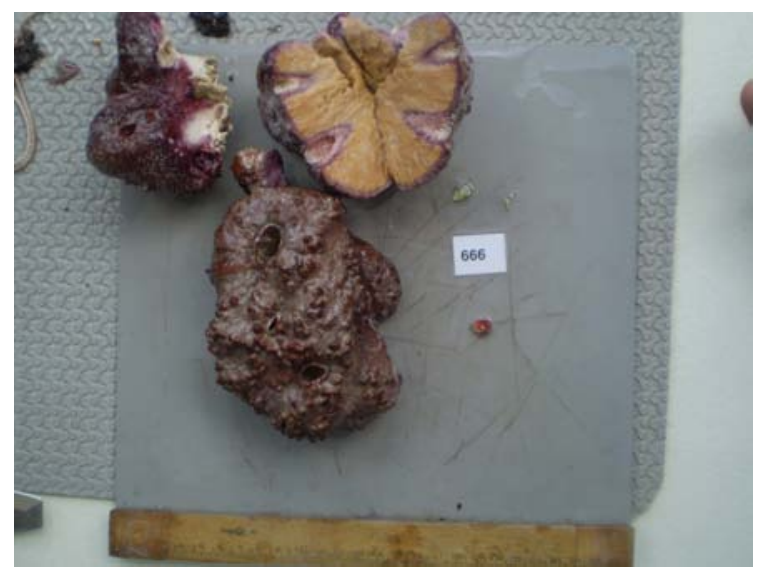

Figure 3.12. Surface photo of the PTN4_05D.

\section{PTN4_10A}

PTN4_10A is an unidentified black sponge (1449 g) collected from Fakafotulā, Vava 'u, Tonga. $21 \mathrm{~g}$ was screened and the screen spectra of the $75 \% \mathrm{Me}_{2} \mathrm{CO} / \mathrm{H}_{2} \mathrm{O}$ fraction contained resonances largely attributed to heteroaromatics. Further purification of this fraction led to the isolation of known compounds makaluvamine $G(\mathbf{5 5})$ and prianosin $B$ (56). The isolation of compounds $\mathbf{5 5}$ and $\mathbf{5 6}$ will be discussed in Chapter 4 . 


\section{Chapter 4}

\section{The Isolation of Known Compounds from Tongan}

\section{Sponges}

\subsection{Order Verongida}

The lack of mineral spicules in the order Verongida makes their taxonomic identification more difficult. Verongid sponges range in form, from tall tubular vases to thin spreading crusts. Stalk formation is also a common feature. Verongids show a common marked oxidative colour change at death or exposure to air, changing from yellow/yellow-green to dark brown, or more frequently deep purple/black. Pigmentation in some sponges is attributable to cyanobacteria. The order consists of four families: Aplysinidae, Aplysinellidae, Ianthellidae and Pseudoceratinidae, as shown in Table 4.1. ${ }^{21}$ Verongids are extremely distinct biochemically, they contain a vast array of bromotyrosine-derived compounds, which occur in all genera that have been studied. ${ }^{21}$ In this study, two sponges (Figures 4.1 and 4.6) were examined and were tentatively identified as Verongid sponges based on their chemical constituents.

Table 4.1. Taxonomic Classification of the Order Verongida. ${ }^{21}$

\begin{tabular}{lll} 
Class & Order & Family \\
\hline \hline Demospongiae & & \\
\hline & Verongida & \\
\cline { 2 - 3 } & & Aplysinidae \\
& Aplysinellidae \\
& & Ianthellidae \\
& & Pseudoceratinidae \\
\hline \hline
\end{tabular}

\subsubsection{Bromotyrosine Derivatives}

As mentioned before, marine sponges of the order Verongida have been noted to be a rich source of bromotyrosine-derived secondary metabolites with interesting biological 
activities. The unusually large number of biosynthetically related compounds has been linked to the potentially large number of chemical variations that are possible within the aromatic ring and/or side chains of the tyrosine moiety. The aromatic ring can be either maintained, reduced, oxidised or mono- or dibrominated. ${ }^{58-60}$ The bromotyrosine moiety can also undergo rearrangement to a spirooxepinisoxaline system, presumably via a common oxide intermediate as in the case of the psammaplysins. ${ }^{61-63}$ Alternatively, the bromotyrosine can be rearranged to form the spirocyclooxazoline moiety, such as in fistularins and aerothionin-1. ${ }^{64,65}$ The bromotyrosine units can also link up to form linear chains through amide bonds as in the case of fistularin- $3,{ }^{64}$ or through ether bonds as in the formation of macrocyclic bastadins. ${ }^{66-68}$ Currently, there are over 300 metabolites isolated from Verongid sponges, ${ }^{69}$ and therefore the isolation of new metabolites from these sponges is a real challenge..$^{70,71}$

\subsubsection{PTN3 33F}

PTN3_33F was collected by snorkel from Ano Beach, Vava'u, Tonga. The sponge was massive, with a yellow-green pigmented surface and yellow interior (Figure 4.1). The sponge oxidised rapidly to dark black at death. The sponge was extracted twice in $\mathrm{MeOH}$ and the extracts were cyclic loaded onto reversed-phase PSDVB beads. The resin was batch eluted with increasing amounts of $\mathrm{Me}_{2} \mathrm{CO}$ in $\mathrm{H}_{2} \mathrm{O}$ (Scheme 4.1). NMR examination of the screen fractions showed that the interesting signals were confined to the $75 \%$ $\mathrm{Me}_{2} \mathrm{CO} / \mathrm{H}_{2} \mathrm{O}$ fraction, containing two major structural related compounds.

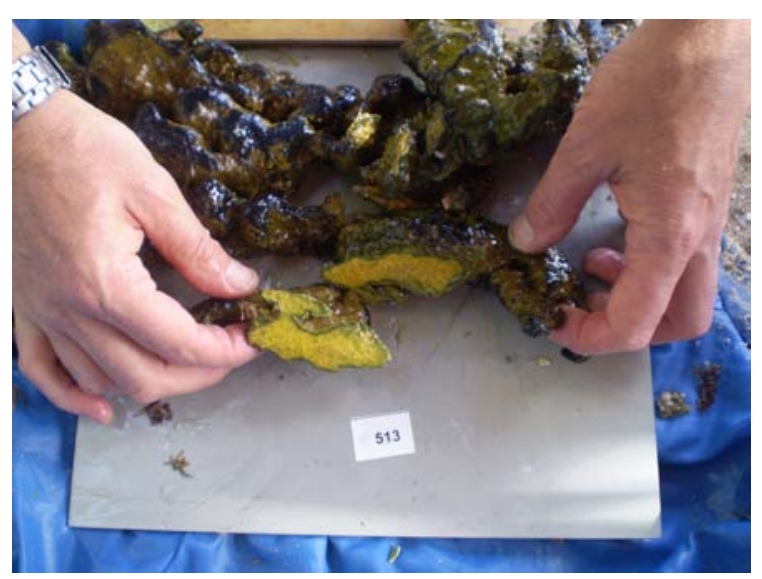

Figure 4.1. Surface photograph of the sponge PTN3_33F. 


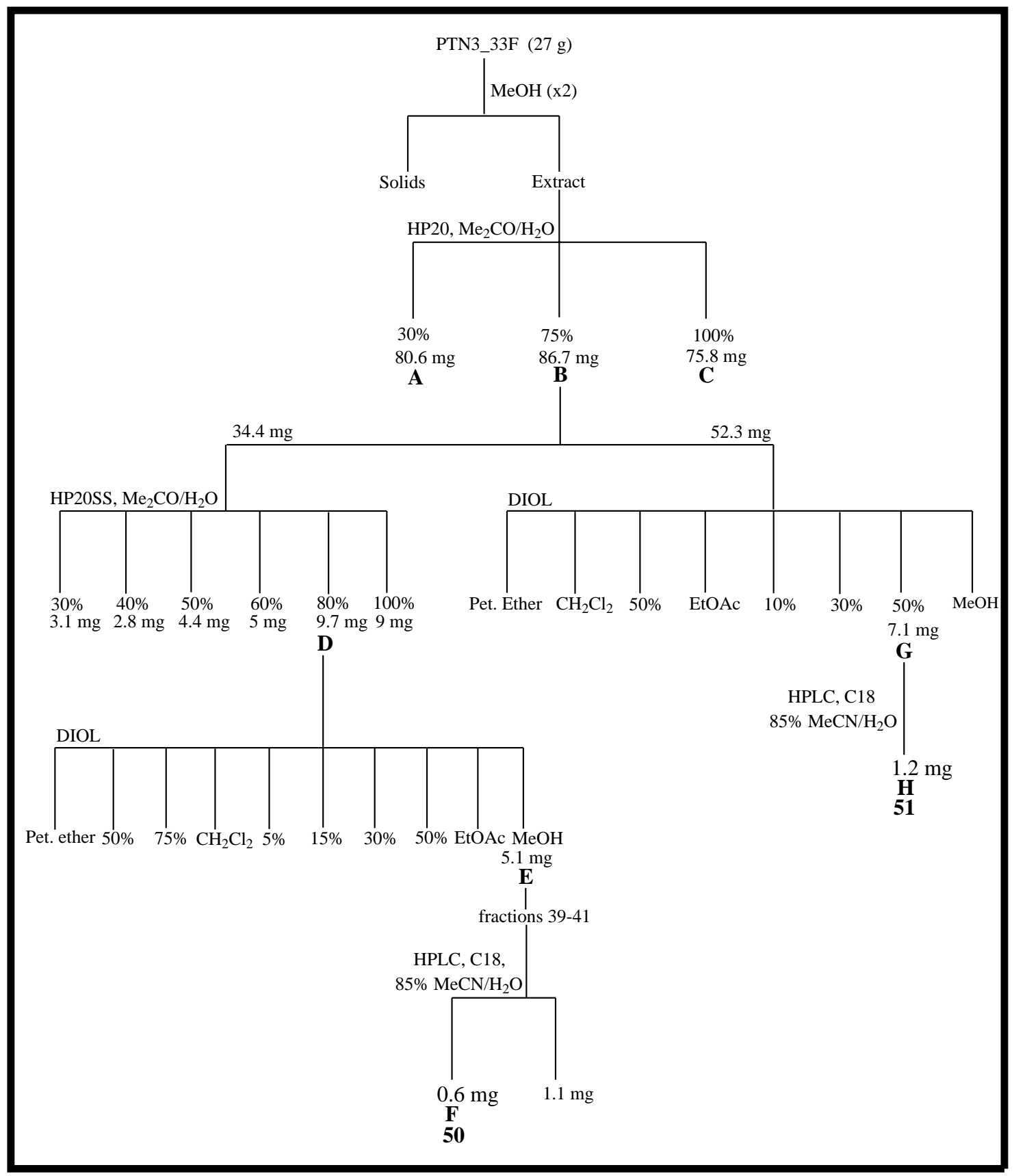

Scheme 4.1. Isolation of aplysamine-2 (50) and aerophobin-1 (51) from PTN3_33E, collected from Vava'u, Tonga.

The HSQC screen spectrum (Figure 4.2) revealed interesting correlations from several aromatic methines $\left(\delta_{\mathrm{H}} \quad 6.90-7.43 ; \delta_{\mathrm{C}} \quad 113.1-134.7\right)$ and a number of deshielded methylene $\left(\delta_{\mathrm{H}} 3.43-4.08 ; \delta_{\mathrm{C}}\right.$ 28.7-71.6) resonances, attributed to one major compound. Analysis of the COSY correlations from these aromatic resonances allowed construction of one spin system (Figure 4.3). This was supported by the characteristic coupling pattern in the ${ }^{1} \mathrm{H}$ NMR spectrum (Figure 4.4), which is consistent with a 1,2,4-trisubtituted benzene ring $\left(\mathrm{H}-5: \delta_{\mathrm{H}} \quad 7.44, \mathrm{~d}, 2.2 \mathrm{~Hz} ; \mathrm{H}-2: \delta_{\mathrm{H}} \quad 6.90, \mathrm{~d}, 8.5 \mathrm{~Hz} ; \mathrm{H}-1: \delta_{\mathrm{H}} \quad 7.18\right.$, dd, 2.2, 8.5 Hz). The ${ }^{1} \mathrm{H}$ NMR spectrum, showed a signal of an isolated aryl proton (H-13: 
$\delta_{\mathrm{H}} 7.43,2 \mathrm{H}$, br s), consistent with a symmetrically tetrasubstituted aromatic ring. Several of the aromatic proton resonances showed further COSY correlations into the aliphatic region of the spectrum. Purification of the $75 \% \mathrm{Me}_{2} \mathrm{CO} / \mathrm{H}_{2} \mathrm{O}$ fraction using NMR-guided fractionation, led to the isolation of the compound. Comparision of the NMR data with published data revealed the known compound aplysamine-2 (50). Compound 50 was originally reported in 1989 from an Australian marine sponge Aplysina sp. ${ }^{72}$

Analysis of the HMBC (Figure 4.5) and HSQC screen spectra revealed interesting correlations from several olefinic methines $\left(\delta_{\mathrm{H}} 6.41-8.30 ; \delta_{\mathrm{C}} \quad 117.7-135.4\right)$ and an oxygenated methyl $\left(\mathrm{CH}_{3}-15: \delta_{\mathrm{H}} \quad 3.71 ; \delta_{\mathrm{C}} \quad 60.4\right)$ and methine $\left(\mathrm{CH}-1: \delta_{\mathrm{H}} \quad 4.08 ; \delta_{\mathrm{C}} \quad 75.5\right)$, attributed to the other major compound. COSY correlations from these olefinic methine resonances revealed two individual spin systems. Inspection of the ${ }^{1} \mathrm{H},{ }^{13} \mathrm{C}, \mathrm{COSY}$ and HMBC NMR spectra suggested that the following proton signals belonged to the same spin system $\left(\mathrm{H}-5: \delta_{\mathrm{H}}\right.$ 6.41, H-1: $\delta_{\mathrm{H}}$ 4.08, H-15: $\delta_{\mathrm{H}}$ 3.71) and an $\mathrm{AB}$ system $\left(\mathrm{H}_{2}-7\right.$ : $\delta_{\mathrm{H}} \quad 3.76$ and $\delta_{\mathrm{H}} 3.08$ ) characteristic of a spirocyclooxazoline ring system previously encountered in other Verongida compounds. ${ }^{65}$ The other spin system contained two aromatic methines appearing as broad singlets at $\delta_{\mathrm{H}} 7.15(\mathrm{H}-13)$ and $8.30(\mathrm{H}-14)$; which showed weak COSY correlation to each other. In the HSQC spectrum, $\delta_{\mathrm{H}} 7.15$ and 8.30 have large ${ }^{1} J_{\mathrm{CH}}(198 \mathrm{~Hz}$ and $214 \mathrm{~Hz}$ repectively), which were consistent with coupling constants of an imidazole ring. Further analysis of the NMR data and sub-structure searchs of the literature revealed the known compound aerophobin-1 (51). Compound 51 was first isolated from marine sponge Verongia aerophoda. ${ }^{73}$



50

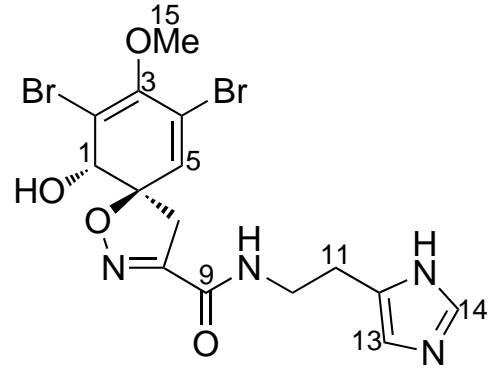

51 


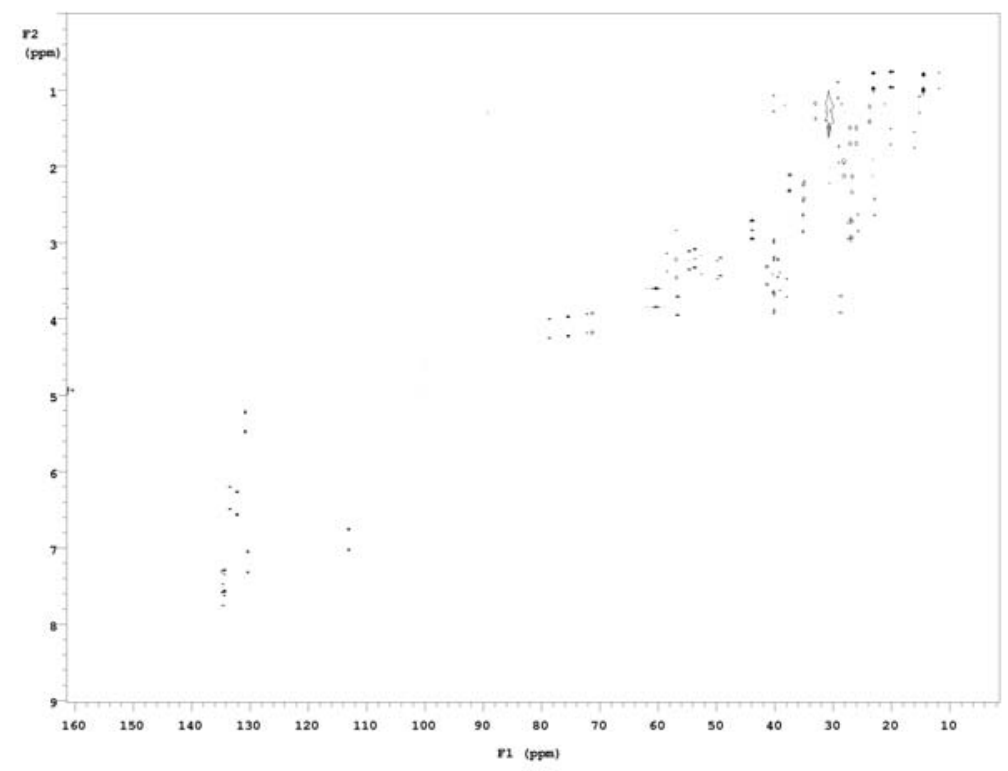

Figure 4.2. $\mathrm{HSQC}$ NMR screen spectrum $\left(600 \mathrm{MHz}, \mathrm{CD}_{3} \mathrm{OD}\right)$ of the $75 \% \mathrm{Me}_{2} \mathrm{CO} / \mathrm{H}_{2} \mathrm{O}$ fraction of PTN3_33F.

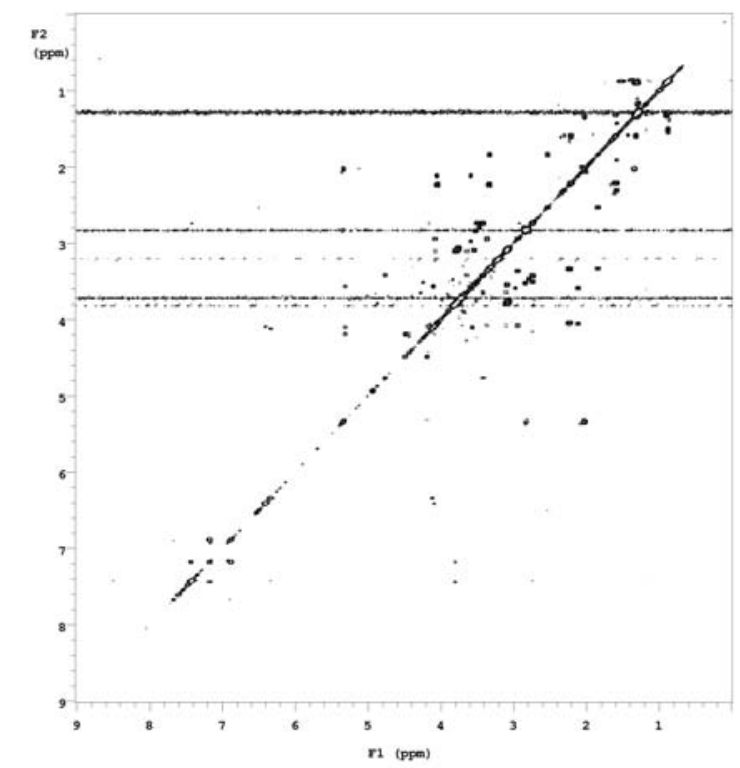

Figure 4.3. COSY NMR screen spectrum $\left(600 \mathrm{MHz}, \mathrm{CD}_{3} \mathrm{OD}\right)$ of the $75 \% \mathrm{Me}_{2} \mathrm{CO} / \mathrm{H}_{2} \mathrm{O}$ fraction of PTN3_33F. 


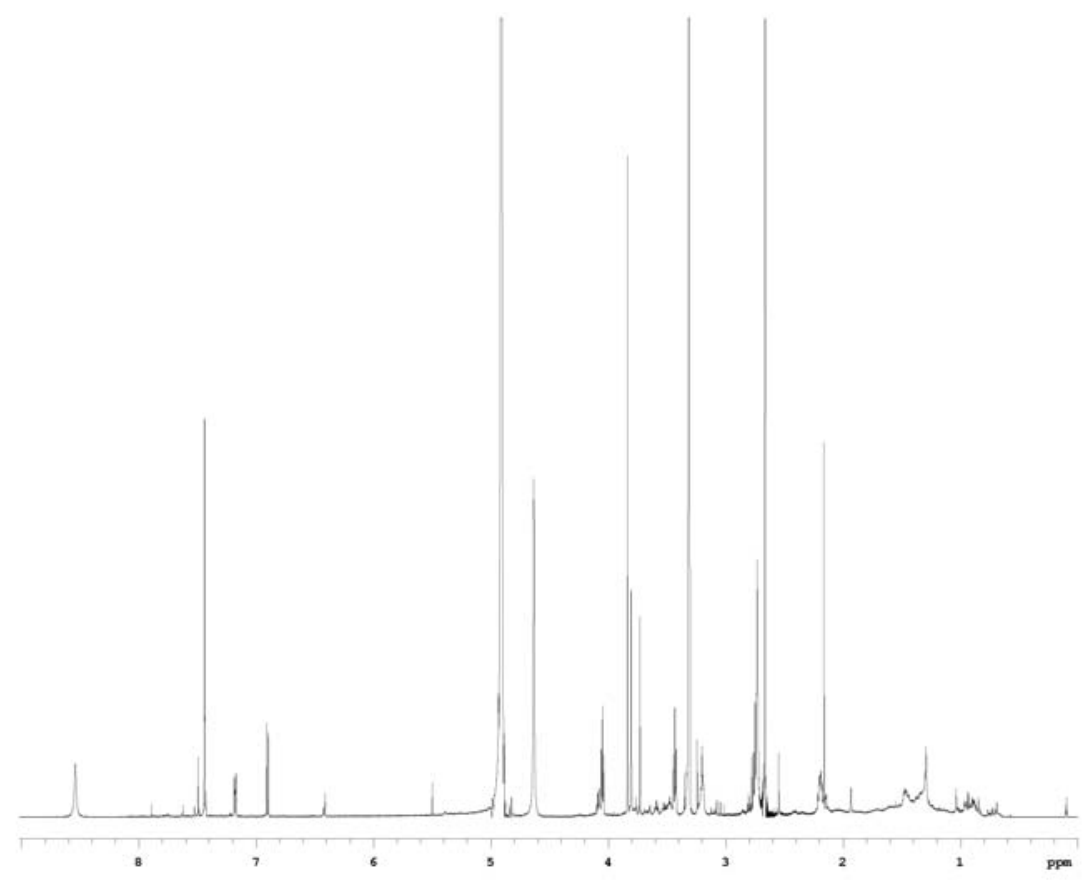

Figure 4.4. ${ }^{1} \mathrm{H}$ NMR screen spectrum $\left(600 \mathrm{MHz}, \mathrm{CD}_{3} \mathrm{OD}\right)$ of the $75 \% \mathrm{Me}_{2} \mathrm{CO} / \mathrm{H}_{2} \mathrm{O}$ fraction of PTN3_33F.



Figure 4.5. $\mathrm{HMBC}$ NMR screen spectrum $\left(600 \mathrm{MHz}, \mathrm{CD}_{3} \mathrm{OD}\right)$ of the $75 \% \mathrm{Me}_{2} \mathrm{CO} / \mathrm{H}_{2} \mathrm{O}$ fraction of PTN3_33F. 


\subsubsection{PTN3_46E}

PTN3_46E was a small creamy-pink sponge with thin spreading crusts, collected from Tu'ungasika Island, Vava'u, Tonga in late November 2009 (Figure 4.6). Interestingly, upon exposure to air or at death, no change in pigmentation was observed. The sponge was extracted twice in $\mathrm{MeOH}$ and the extracts were cyclic loaded on to a column of reversed-phase PSDVB resin. The resin was batch eluted with increasing amounts of $\mathrm{Me}_{2} \mathrm{CO}$ in $\mathrm{H}_{2} \mathrm{O}$ and the fractions analysed by NMR. The $75 \% \mathrm{Me}_{2} \mathrm{CO} / \mathrm{H}_{2} \mathrm{O}$ fraction appeared to contain one main compound and a mixture of structurally similar compounds. Further chromatographic steps employing bench-top reversed- and normalphase chromatography (depicted in Scheme 4.2) led to the isolation of the three known bromotyrosine compounds.

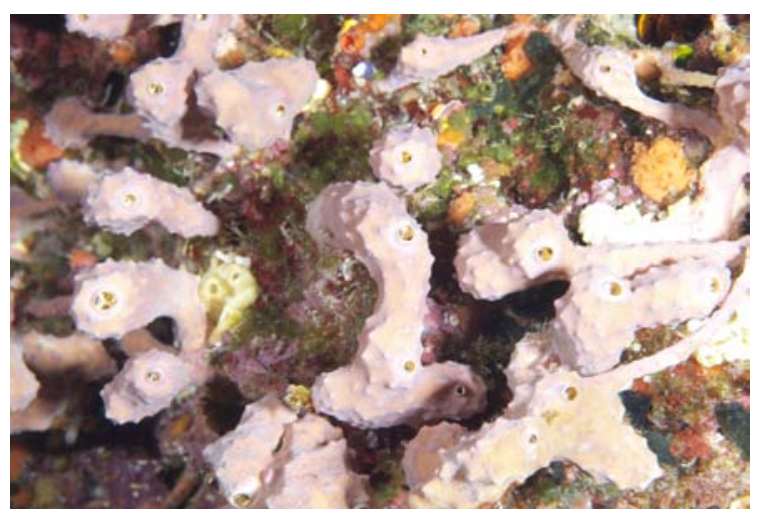

Figure 4.6. Underwater photograph of the sponge PTN3_46E. Courtesy of Karen Stone. 


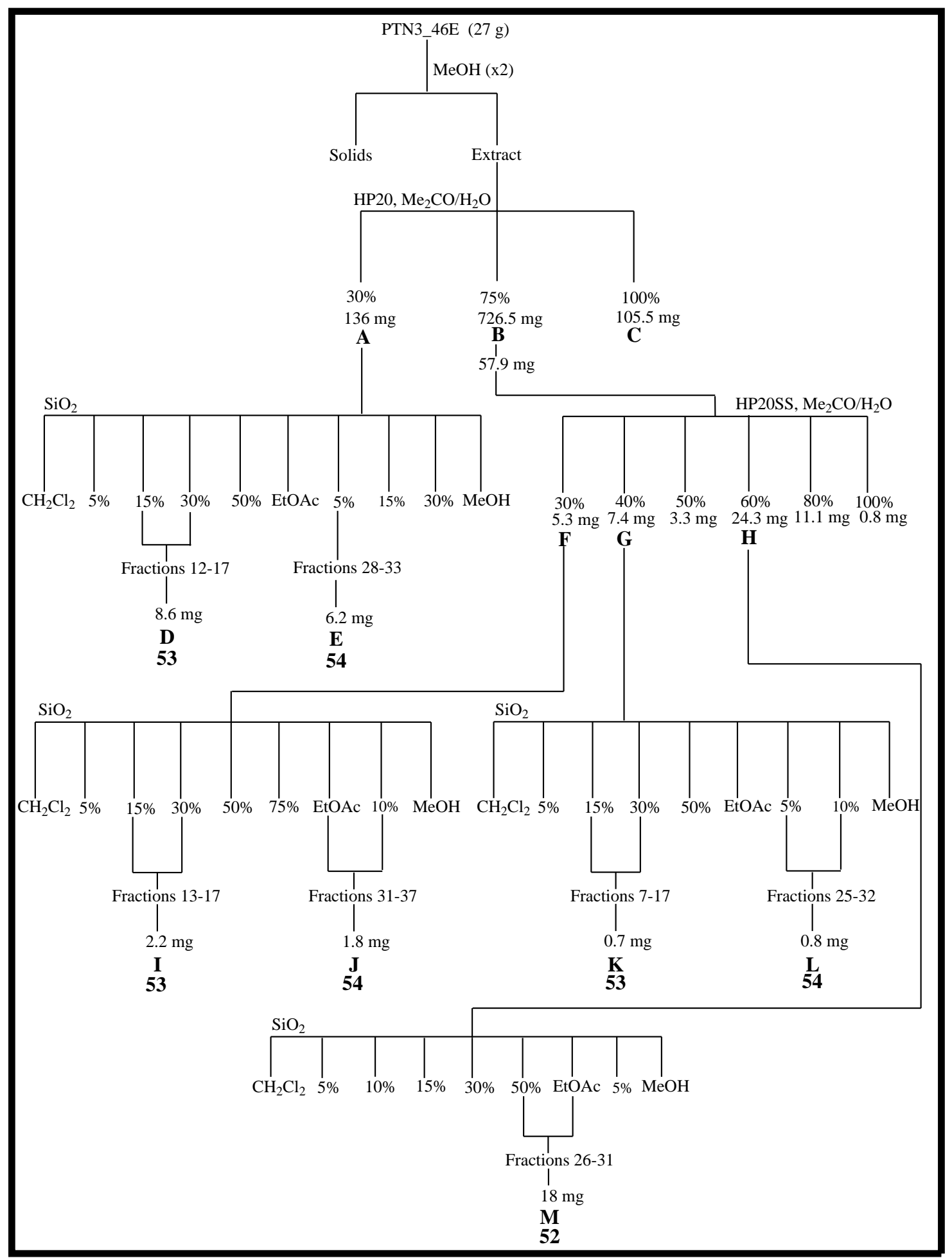

Scheme 4.2. Isolation of fistularin-3 (52), aeroplysinin-1 (53) and LL-PAA216 (54) from PTN3_46E, collected from Vava' $u$, Tonga.

Initial analysis of the NMR spectra of the major compound showed characteristics of a spirocyclooxazoline ring system $\left(\mathrm{H}-5: \delta_{\mathrm{H}} \quad 6.42, \mathrm{H}-1: \delta_{\mathrm{H}} \quad 4.11, \mathrm{H}-19 \delta_{\mathrm{H}} \quad 3.73\right.$, and an $\mathrm{AB}$ system $\left(\mathrm{H}-7: \delta_{\mathrm{H}} 3.78\right.$ and $\left.\delta_{\mathrm{H}} 3.10\right)$ as encountered in aerophobin-1 (51). The compound also has a symmetrically tetrasubstituted aromatic ring $\left(\mathrm{H}-15: \delta_{\mathrm{H}} 7.62,2 \mathrm{H}, \mathrm{bs}\right)$ similar to that of aplysamine-2 (50), thus identifying the major segments of the molecule. 
The HSQC spectrum revealed the presence of two highly polarised oxymethines $(\mathrm{C}-11$ $\delta_{\mathrm{H}} 4.11 ; \delta_{\mathrm{C}}$ 70.0: C-17 $\delta_{\mathrm{H}} 4.77 ; \delta_{\mathrm{C}} 71.6$ ) (consistent by their large ${ }^{1} J_{\mathrm{CH}}$ of 145 and $146 \mathrm{~Hz}$ ). Further analysis of the NMR spectra (see Table 4.2 and Appendix E for NMR data and spectra respectively) revealed fistularin-3 (52). In 1979, fistularin-3 (52) was reported along with fistularin-1 (57) and fistularin-2 (58) from the marine sponge Aplysina fistularis. ${ }^{64}$

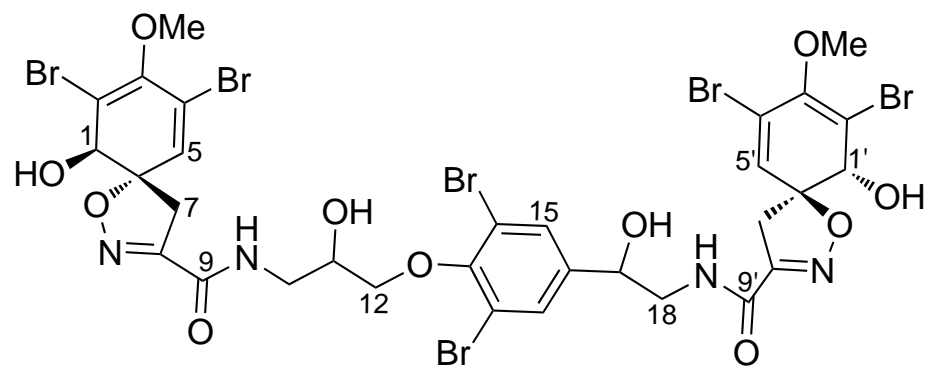

52<smiles>COC1=C(Br)[C@@H](O)[C@]2(C=C1Br)CC(C(=O)NCC(O)COc1c(Br)cc(C3CNC(=O)O3)cc1Br)=NO2</smiles>

57<smiles>COC1=C(Br)[C@@H](O)[C@]2(C=C1Br)CC(C(=O)NCC(O)c1cc(Br)c(OCC3COC(=O)N3)c(Br)c1)=NO2</smiles>

58

Analysis of the NMR spectra for the second bromotyrosine compound, initially suggested the presence of another spirohexadienyl moiety. However, the chemical shifts of C-7 $\left(\delta_{\mathrm{H}} 2.81,2.85 ; \delta_{\mathrm{C}} 25.5\right)$ and $\mathrm{C}-8\left(\delta_{\mathrm{C}} 116.6\right)$ in this compound were different from those $\left(\mathrm{H}-7: \delta_{\mathrm{H}} 3.10,3.78 ; \mathrm{C}-7: \delta_{\mathrm{C}} 40.1 ; \mathrm{C}-8: \delta_{\mathrm{C}}\right.$ 155.1) of 52. In addition, the chemical shift of the oxygenated spiro-carbon (C-6: $\left.\delta_{\mathrm{C}} 74.3\right)$ was considerably different from the spirocarbon of the isoxazoline structure in compound 52 (C-6: $\delta_{\mathrm{C}}$ 92.5). A correlation was observed from the methylene proton $\mathrm{H}_{2}-7$ to $\mathrm{N}-10$ in the ${ }^{1} \mathrm{H}-{ }^{15} \mathrm{~N}$ HMBC spectrum. The ${ }^{15} \mathrm{~N}$ chemical shift appears at -134.6 , which is consistent with that of a nitrile, 
revealing $\mathbf{5 3}$ (see Table 4.3 and Appendix F for NMR data and spectra respectively). This was confirmed by the positive-ion mode HRESIMS analysis of the compound, which gave the molecular formula of $\mathrm{C}_{9} \mathrm{H}_{9} \mathrm{NO}_{3} \mathrm{Br}_{2}\left(359.8847[\mathrm{M}+\mathrm{Na}]^{+}, \Delta 0.0 \mathrm{ppm}\right)$ with pseudomolecular ion clusters $\left([\mathrm{M}+\mathrm{Na}]^{+}:[\mathrm{M}+2+\mathrm{Na}]^{+}:[\mathrm{M}+4+\mathrm{Na}]^{+}\right.$, requiring five double-bond equivalents. Aeroplysinin-1 (53) was obtained from the sponge Verongia aerophoba and is the first example of a naturally occurring 1,2-dihydroarene-1,2-diol. ${ }^{74}$

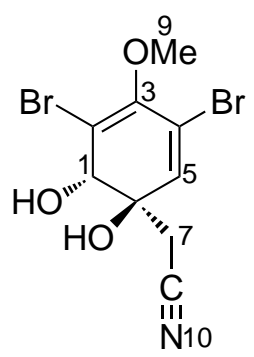

53

Structural elucidation of the last bromotyrosine compound revealed a substructure similar to that of fistularin-3 (52), but without the two spiroisoxazoline rings on either side (shown in Figure 4.7). Therefore this was thought to be a novel derivative of 52. HRESIMS of the compound showed a characteristic pseudomolecular ion cluster $\left([\mathrm{M}+\mathrm{Na}]^{+}\right.$: $\left.[\mathrm{M}+2+\mathrm{Na}]^{+}:[\mathrm{M}+4+\mathrm{Na}]^{+}:[\mathrm{M}+6+\mathrm{Na}]^{+}:[\mathrm{M}+8+\mathrm{Na}]^{+}\right)$indicating a molecular formula of $\mathrm{C}_{26} \mathrm{H}_{24} \mathrm{~N}_{4} \mathrm{O}_{10} \mathrm{Br}_{4}\left(890.8124[\mathrm{M}+\mathrm{Na}]^{+}, \Delta 0.0 \mathrm{ppm}\right)$, requiring fifteen doublebond equivalents. Since there were only 13 carbons reasonance observed in the ${ }^{13} \mathrm{C}$ NMR spectrum, the molecule was suspected to be a dimer with a symmetrical structure. Attempted acetylation of the compound did not indicate the presence of any hydroxyl groups. Therefore, the sample was re-submitted for mass analysis using both positiveand negative-ion modes. Negative-ion mode HRESIMS analysis of the compound gave rise to pseudomolecular ion clusters $\left([\mathrm{M}-\mathrm{H}]^{-}:[\mathrm{M}+2-\mathrm{H}]^{-}:[\mathrm{M}+4-\mathrm{H}]^{-}\right.$, indicated a molecular formula of $\mathrm{C}_{13} \mathrm{H}_{12} \mathrm{~N}_{2} \mathrm{O}_{5} \mathrm{Br}_{2}\left(432.9035[\mathrm{M}-\mathrm{H}]^{-}, 0.0 \mathrm{ppm}\right)$. The positiveion mode HRESIMS analysis of the compound gave the same molecular formula of $\mathrm{C}_{13} \mathrm{H}_{12} \mathrm{~N}_{2} \mathrm{O}_{5} \mathrm{Br}_{2}\left(456.9011[\mathrm{M}+\mathrm{Na}]^{+}, \Delta 0.0 \mathrm{ppm}\right)$ with pseudomolecular ion clusters $\left([\mathrm{M}+\mathrm{Na}]^{+}: \quad[\mathrm{M}+2+\mathrm{Na}]^{+}: \quad[\mathrm{M}+4+\mathrm{Na}]^{+}\right.$, requiring eight double-bond equivalents. Further analysis of the NMR spectra using the latter molecular formula with no hydroxyl groups present, and comparision with published literature, revealed LL-PAA216 (54) (see Table 4.4 and Appendix G for NMR data and spectra respectively). LL-PAA216 (54) was 
the first bromo-compound containing 2-oxazolidone, obtained from Verongia lacunosa, collected off the coast of Puerto Rico in $1974 .{ }^{75}$ The problem encountered with the mass spectrometry in this study was also encountered in zamamistatin.<smiles>CC(=O)NCC(O)COc1c(Br)cc(C(O)CNC(C)=O)cc1Br</smiles>

Figure 4.7. Proposed substructure of a compound isolated from PTN3_46E sponge.<smiles>O=C1NCC(COc2c(Br)cc(C3CNC(=O)O3)cc2Br)O1</smiles>

54

Zamamistatin, a novel bromotyrosine derivative, was obtained from the Okinawan sponge Pseudoceratina purpurea in 2001 by Takada et al. ${ }^{76}$ In its ESIMS spectrum, zamamistatin showed 1:4:6:4:1 quintet ion peaks at $m / z 697,699,701,703$, and 705 , indicative of the presence of four bromine atoms with a molecular formula of $\mathrm{C}_{18} \mathrm{H}_{18} \mathrm{Br}_{4} \mathrm{~N}_{2} \mathrm{O}_{6}$. Detailed analysis of the NMR spectra suggested a symmetrical structure for zamamistatin as in 59. However, the chemical shift of the oxygenated spiro-carbon of zamamistatin (C-6: $\delta_{\mathrm{C}}$ 74.3) was considerably different from the spirocarbon of the isoxazoline structure in aerothionin (60) (C-6: $\delta_{\mathrm{C}}$ 91.5). Thus, an endo-type dimer of the azaoxa-spiro[6.6] unit possessing a dihydro-1,2-oxazine ring, as shown in 61, was proposed as another plausible structure in 2006 by Hayakawa et $a l .{ }^{77}$ In 2008 , Kita et al. revised the structure of zamamistatin to that of the known compound aeroplysinin-1 (53), but not an exo- or endo-type dimer $\mathbf{5 9}$ or $\mathbf{6 1}$ which were described previously. ${ }^{78}$<smiles>COC1=C(Br)C(O)[C@@]2(C=C1Br)C/C(=C1/C[C@]3(C=C(Br)C(OC)=C(Br)[C@H]3O)ON1)NO2</smiles> 
<smiles>COC1=C(Br)[C@@H](O)C2(C=C1Br)CC(C(=O)NCCCCNC(=O)C1=NO[C@]3(C=C(Br)C(OC)=C(Br)[C@@H]3O)C1)=NO2</smiles>

60

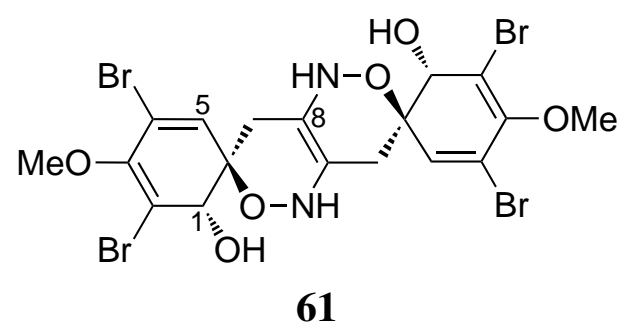

The NMR data for fistularin-3 (52), aeroplysinin-1 (53) and LL-PAA216 (54) in the literature are quite old and the ${ }^{15} \mathrm{~N}$ chemical shifts have not yet been published. Here we report the NMR data for the three compounds (52-54) including the ${ }^{15} \mathrm{~N}$ chemical shifts and the ${ }^{1} J_{\mathrm{CH}}$ values (Tables 4.2, 4.3, 4.4 and 4.5). 

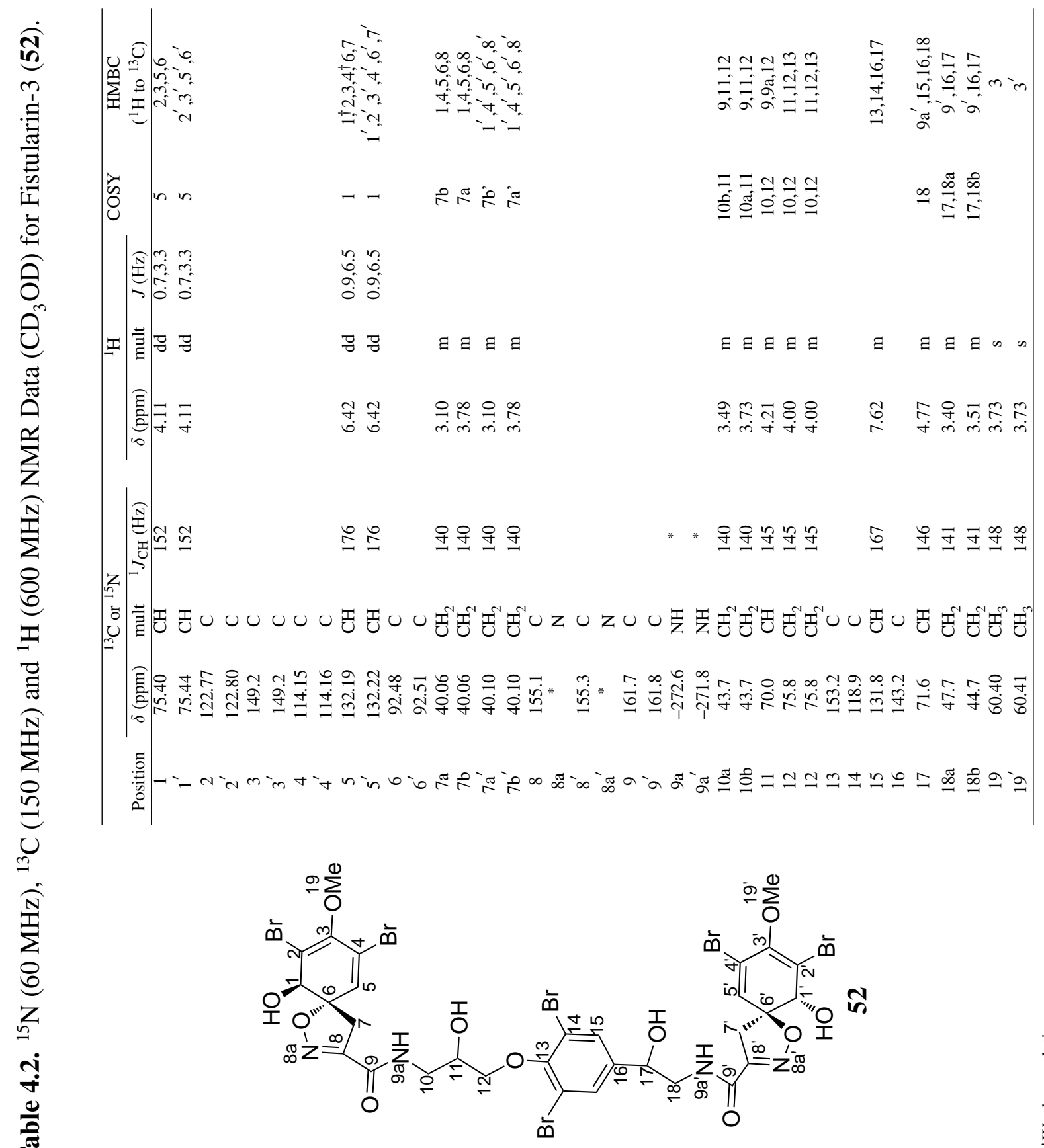


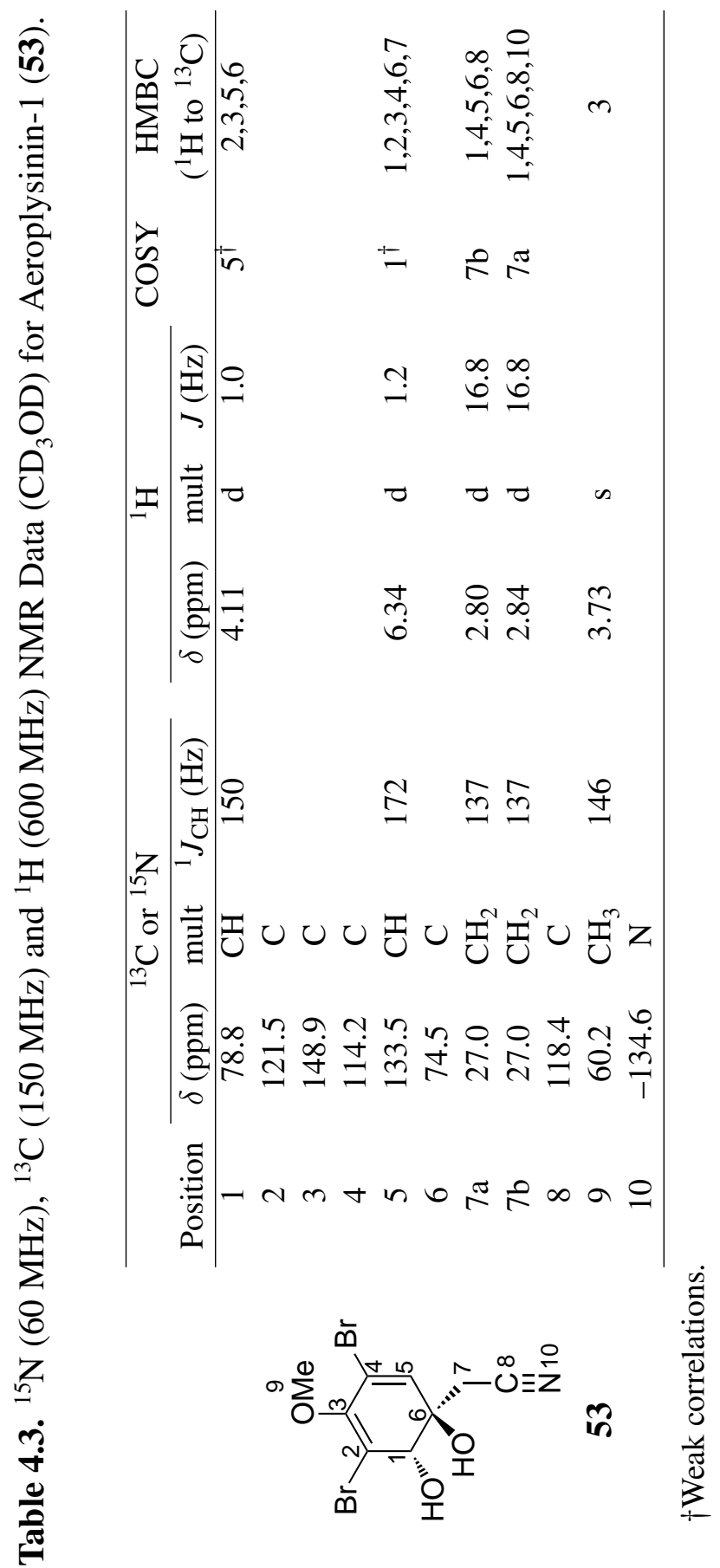




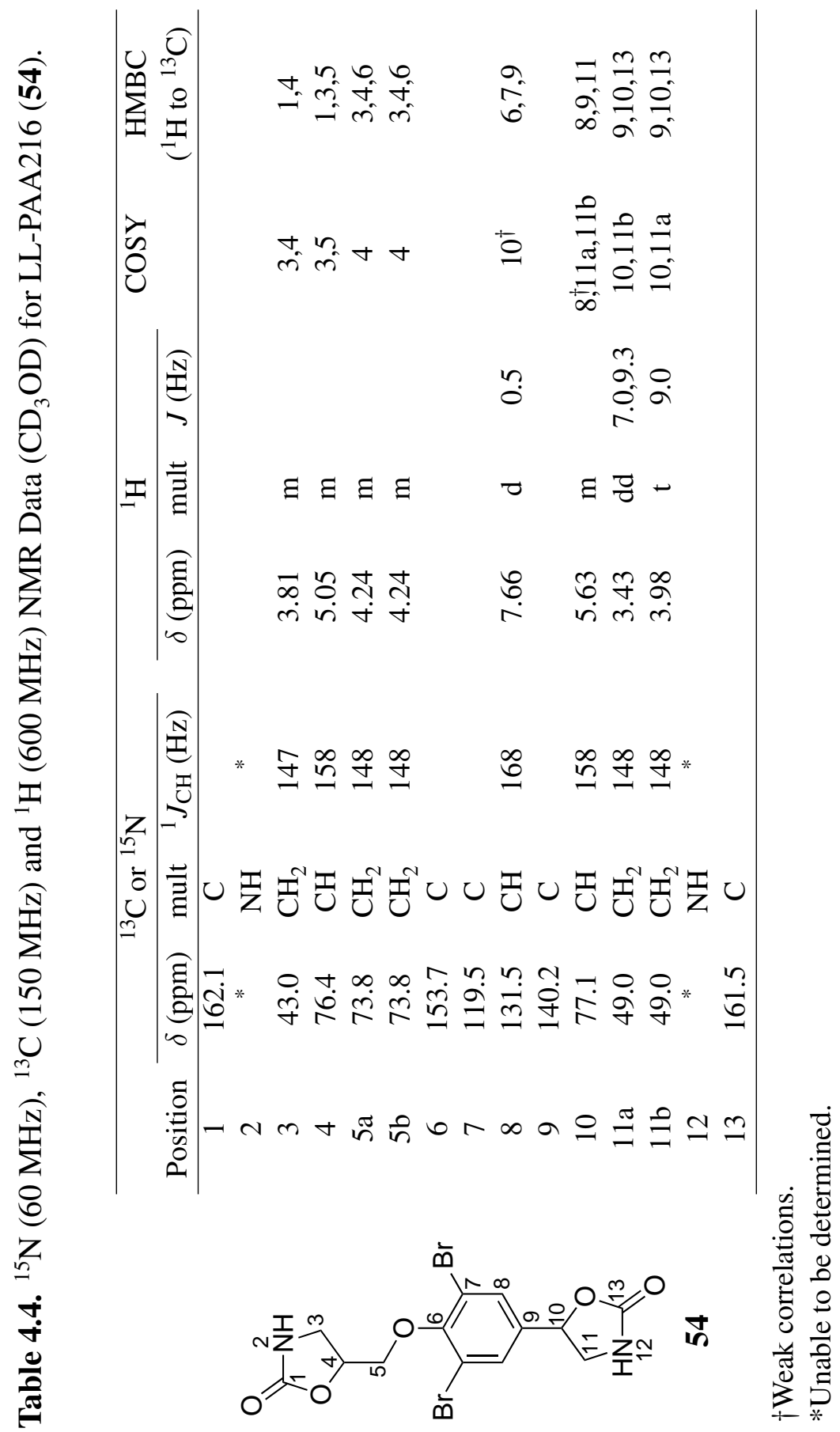




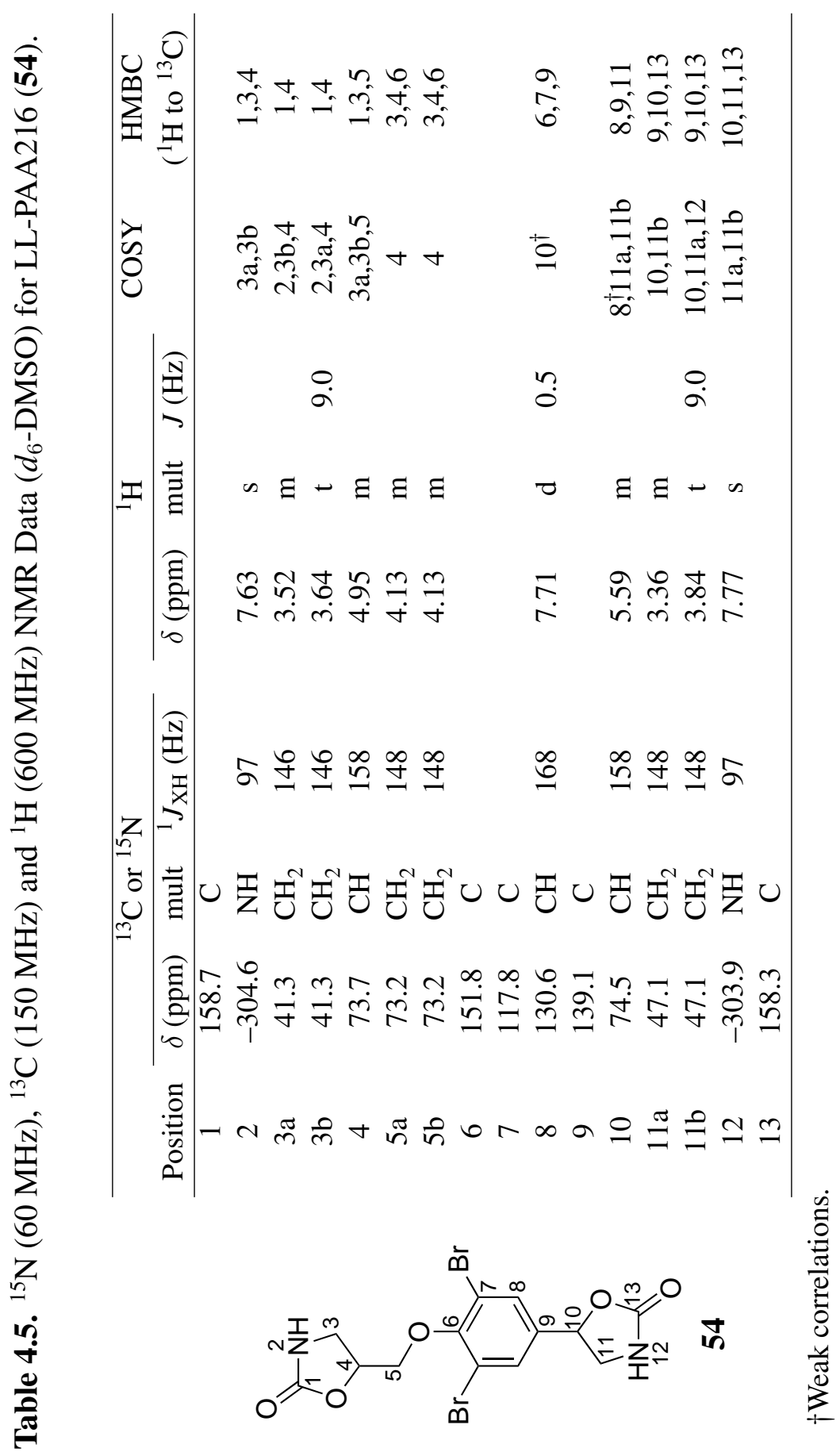




\subsection{Order Poecilosclerida}

The order Poecilosclerida is the most diverse order of Porifera, both in terms of numbers of species and morphology. The order belongs to the sub-class Ceractinomorpha, which is characterised by a skeleton composed of both spicule and spongin fibres. The order consists of 25 families, 129 genera and several thousands of described species worldwide, distributed from intertidal to abyssal depths. ${ }^{21}$ The Latrunculia, Strongylodesma, and Tsitsikamma of the family Latrunculiidae (Table 4.6) have a characteristic base pigmentation of deep brownish black that is often and variously tinged with forest green and deep blue. These specimens exude a dark brownish or greenish black pigment; the ethanol preservative is always oily-looking and deeply pigmented. Preserved specimens always retain their dark pigmentation. ${ }^{21}$

Table 4.6. Taxonomic Classification of Selected Families of the Order Poecilosclerida. ${ }^{21}$

\begin{tabular}{|c|c|c|c|c|}
\hline Class & Order & Suborder & Family & Genus \\
\hline \multicolumn{5}{|c|}{ "Demospongiae } \\
\hline & \multicolumn{4}{|c|}{ Poecilosclerida } \\
\hline & & \multicolumn{3}{|l|}{ Microcionina } \\
\hline & & \multicolumn{3}{|c|}{ Acarnidae } \\
\hline & & $\begin{array}{l}\text { Myxillina } \\
\text { Mycalina } \\
\text { Latrunculina }\end{array}$ & & Zyzzya \\
\hline & & \multicolumn{3}{|c|}{ Latrunculiidae } \\
\hline & & & & $\begin{array}{l}\text { Latrunculia } \\
\text { Sceptrella } \\
\text { Strongylodesma } \\
\text { Tsitsikamma }\end{array}$ \\
\hline
\end{tabular}

\subsubsection{PTN4_10A}

The sponge, PTN4_10A, examined in this study (Figure 4.8) was a massive, soft sponge with deep black colour, both exterior and interior. The methanol extracts of the sponge has a very dark greenish pigment. The sponge was extracted twice in $\mathrm{MeOH}$ and the extracts were cyclic loaded on to a column of reversed-phase PSDVB resin. The resin was batch eluted with increasing amounts of $\mathrm{Me}_{2} \mathrm{CO}$ in $\mathrm{H}_{2} \mathrm{O}$ and the fractions analysed by NMR spectroscopy. The NMR spectra of the $75 \% \mathrm{Me}_{2} \mathrm{CO} / \mathrm{H}_{2} \mathrm{O}$ fraction appeared to contain 
interesting signals, attributed to two major compounds. Further chromatographic steps employing bench-top normal-phase chromatography followed by reversed-phase HPLC (depicted in Scheme 4.3) led to the isolation of two structurally related known compounds.

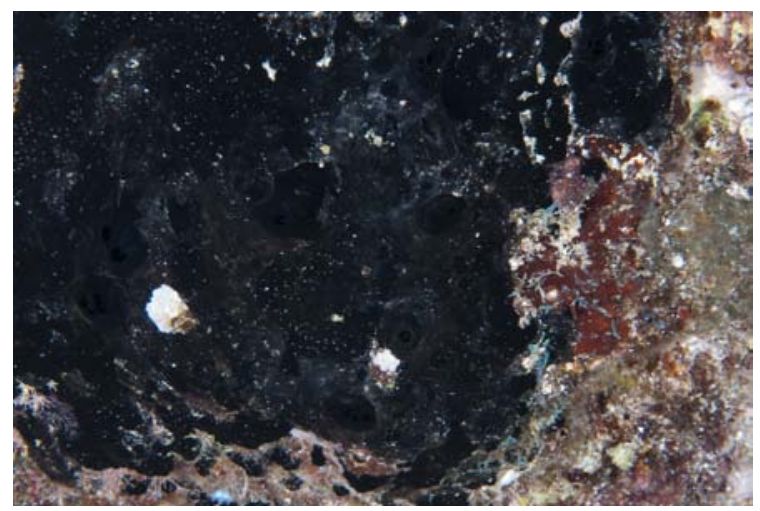

Figure 4.8. Underwater photo of the PTN4_10A sponge (courtesy of Karen Stone). 


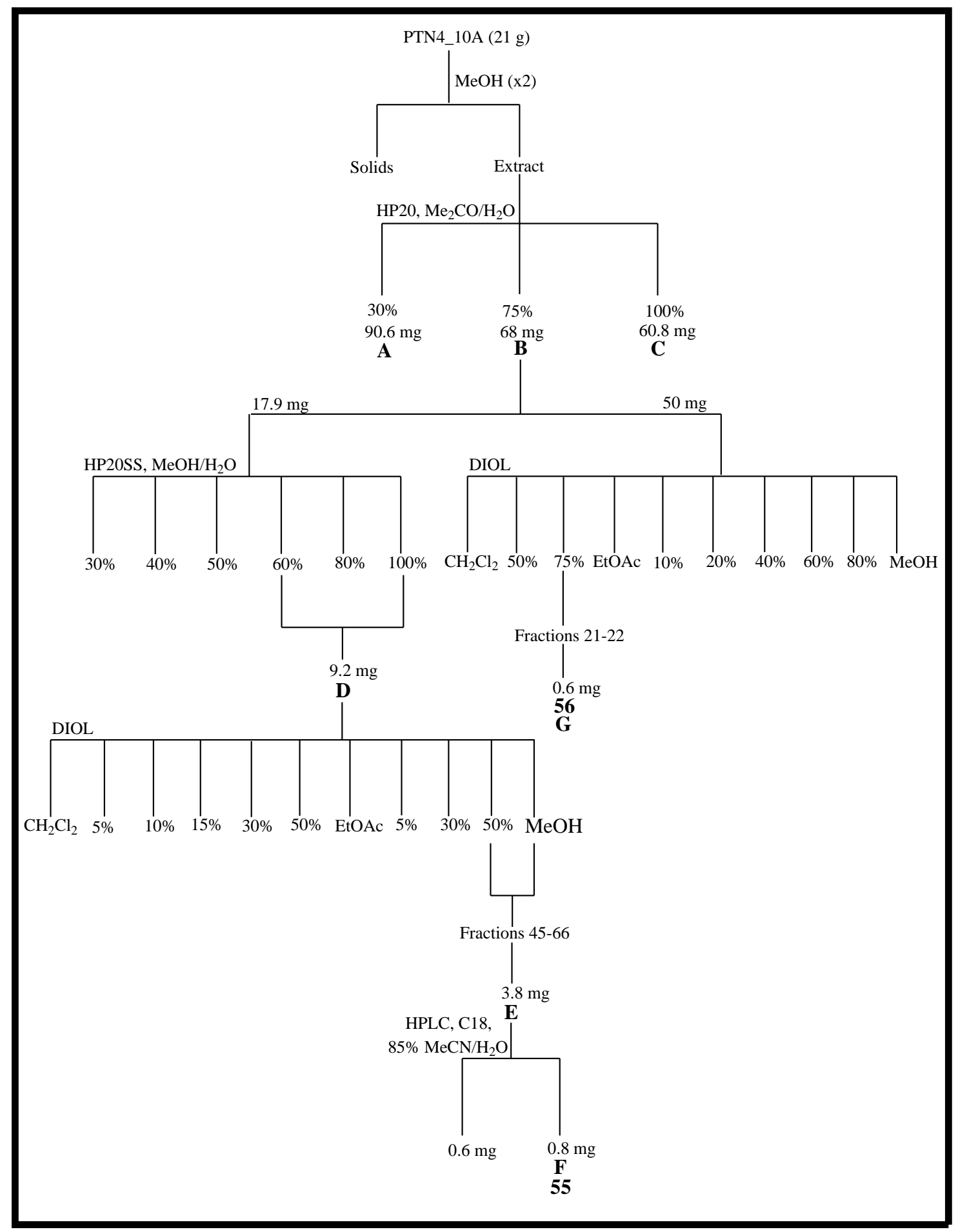

Scheme 4.3. Isolation of makaluvamine G (55) and prianosin B (56) from PTN4_10A, collected from Vava'u, Tonga.

One of the major compounds was isolated as a green-black solid. Inspection of the HSQC screen spectrum indicated the presence of a large variety of deshielded aromatic methines $\left(\delta_{\mathrm{H}} \quad 5.91-7.37 ; \delta_{\mathrm{C}} \quad 85.6-130.5\right)$ and accompanied by two $N$-methyls $\left(\delta_{\mathrm{H}} 3.86\right.$, $\left.3.99 ; \delta_{\mathrm{C}} 35.0,35.2\right)$ and two methylene resonances $\left(\delta_{\mathrm{H}} 2.96-3.86 ; \delta_{\mathrm{C}} 18.1-42.7\right)$. Substantial numbers of couplings from these ${ }^{1} \mathrm{H}$ resonances were noted in the COSY spectrum. Further analysis of the HMBC spectrum and comparision with published 
literature indicated that is a discorhabdin-like compound, revealing makaluvamine $\mathrm{G}(\mathbf{5 5})$. Compound 55, is a cytotoxic pigment originally reported in 1993 by Scheuer et al. from an Indonesian sponge Histodemella sp. ${ }^{79}$ The first examples of the series, makaluvamines A-F, were reported as cytotoxic pigments of a Fijian sponge Zyzzya $\mathrm{cf}$. marsailis $^{80}$ (an incorrect spelling of massalis). The marine sponges Histodemella sp. and Z. cf. marsailis were later re-idenified as Z. fuliginosa. ${ }^{81}$

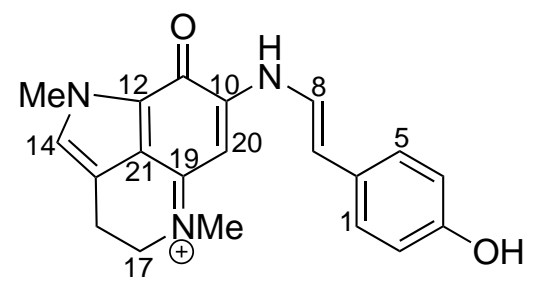

55

The other compound was isolated as red crystals. As for compound 55, several olefinic methines $\left(\delta_{\mathrm{H}} 7.55-8.31 ; \delta_{\mathrm{C}} 126.3-158.2\right)$ were observed in the HSQC spectrum. Several of these olefinic methines showed correlations in the COSY spectrum. In addition, the HSQC spectrum revealed two methylenes $\left(\mathrm{CH}_{2}-7: \delta_{\mathrm{H}} \quad 2.79,2.97 ; \delta_{\mathrm{C}} 40.8\right.$ and $\mathrm{CH}_{2}-4$ : $\left.\delta_{\mathrm{H}} 2.79,3.08 ; \delta_{\mathrm{C}} 46.5\right)$, which indicated the presence of chiral centres in the molecule. Also of interest were two methines with large ${ }^{1} J_{\mathrm{CH}}$ values $\left(\mathrm{CH}-5: \delta_{\mathrm{H}} 4.72 ; \delta_{\mathrm{C}} 57.5,{ }^{1} J_{\mathrm{CH}}\right.$ $149 \mathrm{~Hz}$ and $\mathrm{CH}-8: \delta_{\mathrm{H}} \quad 5.47 ; \delta_{\mathrm{C}} \quad 62.6,{ }^{1} J_{\mathrm{CH}} 163 \mathrm{~Hz}$ ). In its HRESIMS spectrum, this compound showed a molecular formula of $\mathrm{C}_{18} \mathrm{H}_{12} \mathrm{~N}_{3} \mathrm{OSBr}$, which taken together with the detailed analysis of the NMR spectra, revealed this compound as prianosin B (56). Compound 56, a sulfur-containing alkaloid with potent antineoplastic activity, was first obtained from an Okinawan marine sponge Prianos melanos together with prianosins C and D. ${ }^{82}$ The structures of prianosins C and D were later revised by Kobayashi et al. in 1991 to known compounds 2-hydroxydiscorhabdin D (62) and discorhabin D (63), respectively. ${ }^{83}$

In the past, chemotaxonomic trends within marine sponges producing pyrroloquinoline metabolites have suggested that discorhabdins/prianosins and makaluvamines are definitive chemotaxonomic markers for Latrunculia and Zyzzya species, respectively. ${ }^{84,85}$ Further isolation of discorhabdin/prianosin and makaluvamine metabolites from other species within the order Poecilosclerida suggest that this broad chemotaxonomic generalisation may have to be treated with some circumspection. For the same reason, P. melanos has 
been re-identified as a species of Strongylodesma. ${ }^{21}$

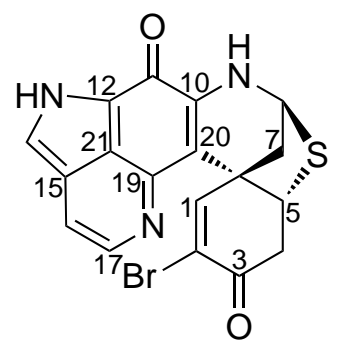

56

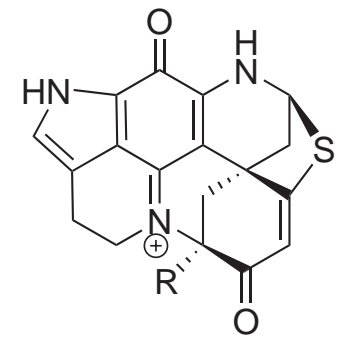

$62 \mathrm{R}=\mathrm{OH}$

$63 \mathrm{R}=\mathrm{H}$

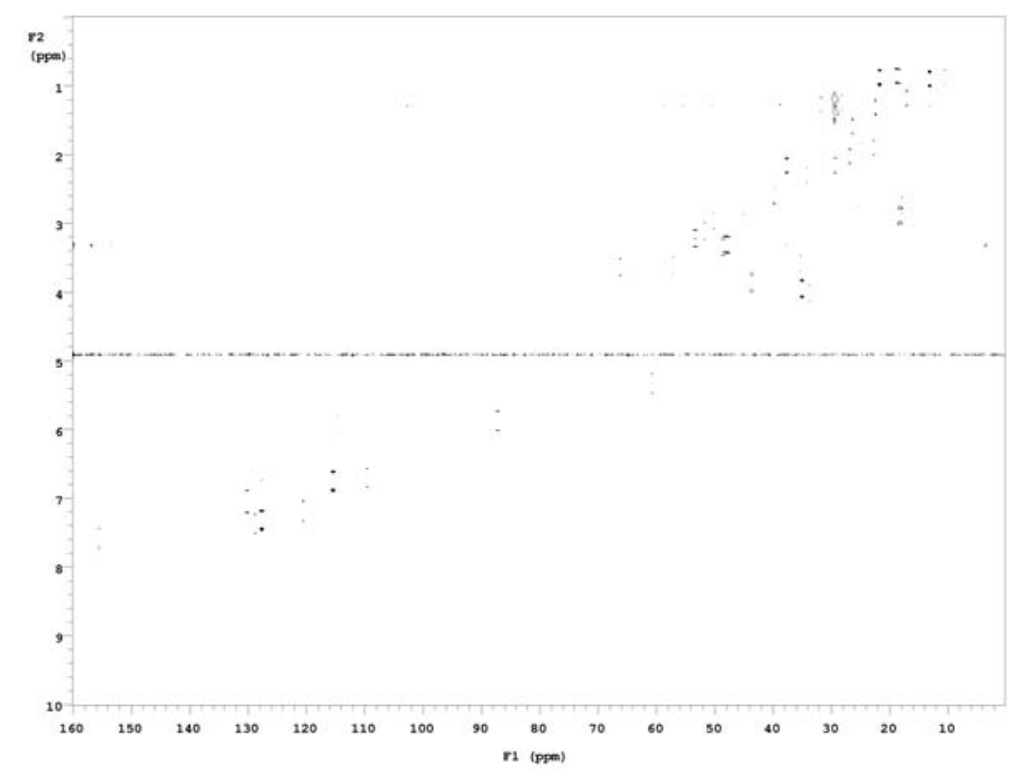

Figure 4.9. $\mathrm{HSQC}$ NMR screen spectrum $\left(600 \mathrm{MHz}, \mathrm{CD}_{3} \mathrm{OD}\right)$ of the $75 \% \mathrm{Me}_{2} \mathrm{CO} / \mathrm{H}_{2} \mathrm{O}$ fraction of PTN4_10A. 


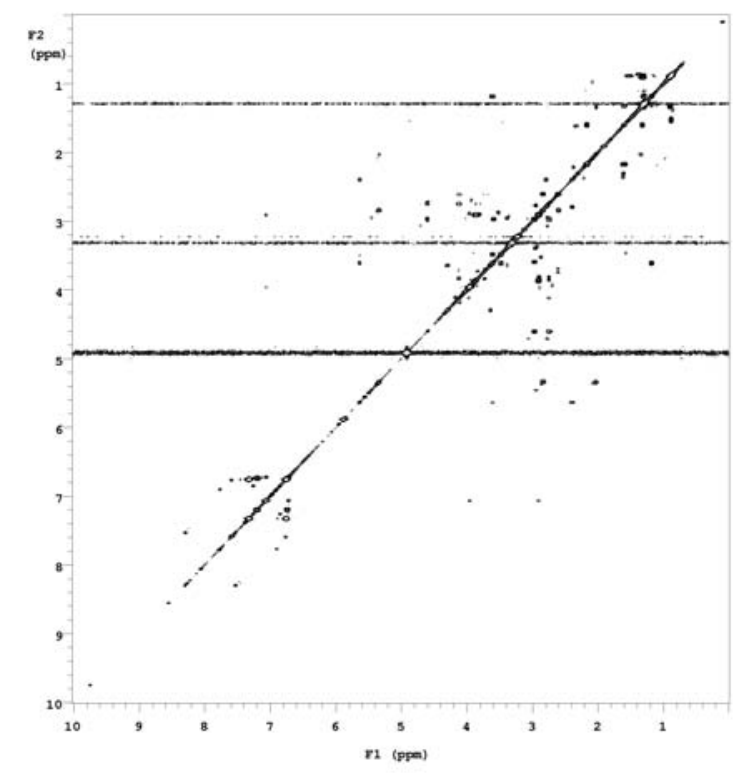

Figure 4.10. COSY NMR screen spectrum $\left(600 \mathrm{MHz}, \mathrm{CD}_{3} \mathrm{OD}\right)$ of the $75 \%$ $\mathrm{Me}_{2} \mathrm{CO} / \mathrm{H}_{2} \mathrm{O}$ fraction of PTN4_10A.

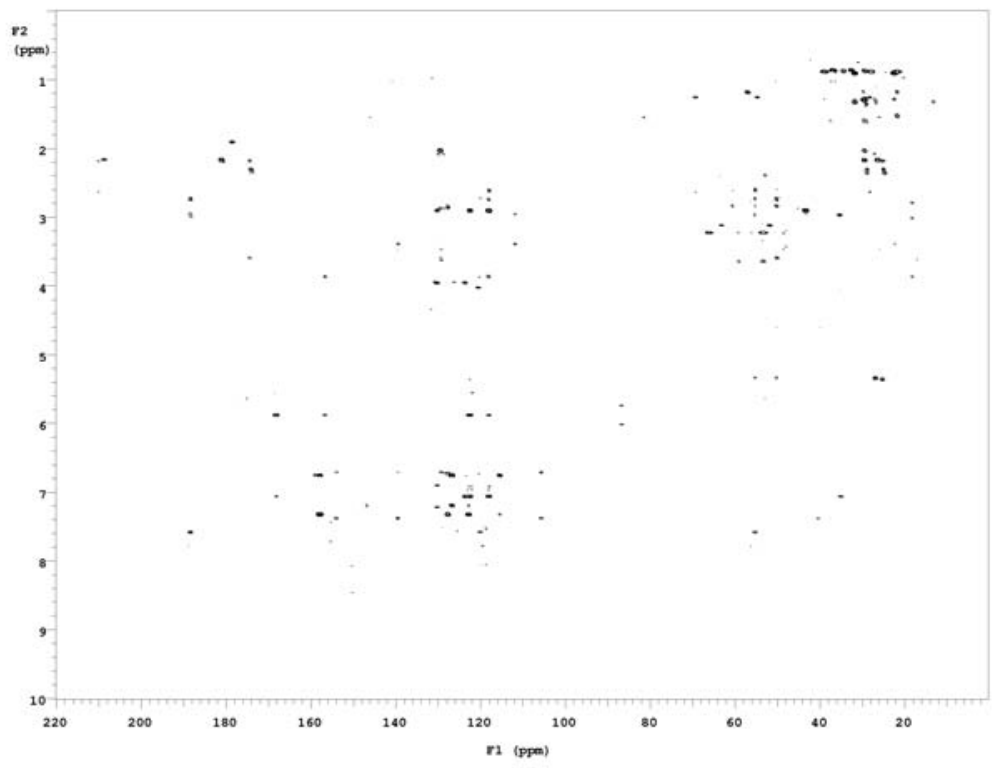

Figure 4.11. $\mathrm{HMBC}$ NMR screen spectrum $\left(600 \mathrm{MHz}, \mathrm{CD}_{3} \mathrm{OD}\right)$ of the $75 \%$ $\mathrm{Me}_{2} \mathrm{CO} / \mathrm{H}_{2} \mathrm{O}$ fraction of PTN4_10A. 


\subsection{Biological Activity}

Fistularin-3 (52), aeroplysinin-1 (53) and prianosin B (56) were evaluated for cytotoxicity against the human promyelocytic leukaemia cell line HL-60 at the School of Biological Sciences, VUW. Compounds 52, 53 and 56 were found to be moderately cytotoxic with $\mathrm{IC}_{50}$ values in the micromolar range $\left(5.09 \mu \mathrm{M}, 1.14 \mu \mathrm{M}, 2.17 \mu \mathrm{M}\right.$ respectively). ${ }^{86}$ LL-PAA216 (54) has been submitted for biological testing to the School of Biological Sciences at VUW, however the results are still pending. 


\section{Chapter 5}

\section{Investigation of Fascaplysinopsis sp.}

\subsection{Fascaplysinopsis sp.}

The genus Fascaplysinopsis belongs to the family Thorectidae, a member of the order Dictyoceratida (Table 5.1). Dictyoceratids do not possess silicaceous spicules, which makes their taxonomic identification more difficult. Thorectids are differentiated from other members of the Dictyoceratida by their strongly laminated skeletal fibres, diplodal choanocyte chambers, and lack of fine skeletal filaments. They range from low and encrusting to massive in growth form and are distributed throughout tropical and temperate oceans. Genera within Thorectidae are differentiated by the absence or presence of a cortical armour. ${ }^{21}$ The genus Fascaplysinopsis has strong and thick primary fibres, collagenous throughout the mesophyl of the sponge. They are found throughout the Indo-Pacific. The Fascaplysinopsis sp. collected from Tongan waters in this study was a massive globular sponge with a shiny red-brown appearance (Figure 5.1).

Table 5.1. Taxonomic classification of genus Fascaplysinopsis from Class

Demospongiae. $^{21}$

\begin{tabular}{llll} 
Class & Order & Family & Genus \\
\hline \hline Demospongiae & & \\
\hline & Dictyoceratida & \\
\cline { 2 - 3 } & \multicolumn{3}{c}{ Dysideidae } \\
& Irciniidae \\
& Spongiidae \\
& Thorectidae & \\
\cline { 2 - 3 } & \multicolumn{3}{c}{ Aplysinopsis } \\
& & Cacospongia \\
& & Fasciospongia \\
& & Fascaplysinopsis \\
& & Hytrios \\
& & Luffariella \\
& & Thorectandra \\
\hline \hline
\end{tabular}




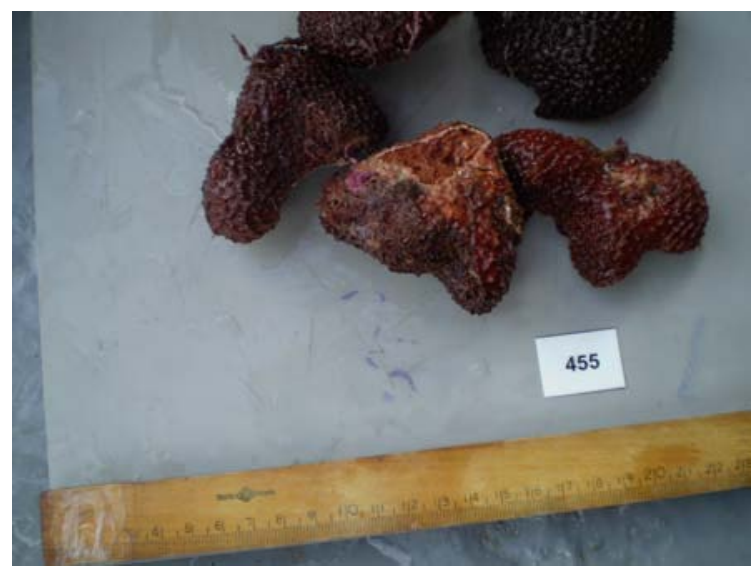

Figure 5.1. Surface photograph of the Fascaplysinopsis sp.

\subsection{Chemical History of the Genus Fascaplysinopsis}

Nitrogen-containing metabolites are not commonly observed from Dictyoceratid sponges, as this order is known to be a rich source of di- or sesterterpenes, while family Thorectidae are sources for both sesterterpenes and amino acid derivatives. ${ }^{26,87,88}$ The first Fascaplysinopsis compounds reported were aplysinopsins (64 and 65), monomeric tryptophan derivatives isolated from a marine sponge of the genus Aplysinopsis (now considered a synonym of $F$. reticulata), which were unaccompanied by terpenoids. ${ }^{21,89}$ Fascaplysin (66), a pentacyclic pyridinium salt from the Fijian sponge Fascaplysinopsis sp., was isolated alongside the known compound luffariellolide (45). ${ }^{90}$ The structure of compound 66 was determined by spectral and X-ray analysis. Compound 66 inhibits the growth of several microbes including Staphylococcus aureus, Escherichia coli, Candida albicans, Saccharomyces cerevisiae, and showed cytotoxicity towards murine leukemia L1210 cells with an $\mathrm{IC}_{50}$ of $0.2 \mu \mathrm{g} / \mathrm{mL} .{ }^{90}$

Subsequently, several structurally related unusual alkaloid-sesterterpene salts have been reported from the Fijian sponge $F$. reticulata, including fascaplysin A (67), fascaplysin B (68), reticulatine A (69), reticulatine B (70) and homofascaplysin A (71), together with sesterterpenoid anions dehydroluffariellolide diacid (72) and isodehydroluffariellolide diacid (73). ${ }^{91,92}$ These compounds were accompanied by neutral alkaloids homofascaplysin B (74), homofascaplysin C (75), secofascaplysin A (76) and sesterterpene isodehydroluffariellolide (44). ${ }^{91,92}$ In 2003, analysis of the same sponge species collected from Indonesia, obtained three compounds 3-bromofascaplysin (77), 14-bromoreticulatine 
(78), and 14-bromoreticulatate (79). ${ }^{93}$ Eight fascaplysin derivatives (80-87) were subsequently isolated from the marine sponge $F$. reticulata collected off different locations in Fiji and Indonesia. ${ }^{94}$

These fascaplysin derivatives were grouped into three main classes due to inconsistent nomenclature in the current literature for tetracyclic and pentacyclic natural products. The first class contains most structural variants closely related to $\mathbf{6 6}$, based on the changes in the extent of conjugation present in the fused pentacyclic chromophore. ${ }^{94}$ These includes homofascaplysin B (74), homofascaplysin C (75), 3-bromofascaplysin (77), 10-bromofascaplysin (80) , 3-10-dibromofascaplysin (81) and homofascaplysate A (82). The other two classes were based on a single bond disconnection severing ring D of the parent compound $\mathbf{6 6}$, as exemplified by the reticulatines $(\mathbf{7 8}, \mathbf{7 9}, \mathbf{8 3}-\mathbf{8 5})$ and the secofascaplysins $(\mathbf{7 6}, \mathbf{8 6}, \mathbf{8 7})$. Compound 80 exhibited human solid tumor selectivity unlike compounds $\mathbf{6 6}$ and 84 showed significant selectivity for human leukemia. ${ }^{94}$ Other studies revealed that compound $\mathbf{6 7}$ showed comparable activity in several tumor lines to $\mathbf{6 6}$ but the presence of the sesterterpene anion causes activity in some cell lines where $\mathbf{6 6}$ is inactive. ${ }^{94}$ Interestingly, the presence of a bromine in $\mathbf{7 7}$ produces an overall increase in activity as compared to 66 and 67 but also causes inactivity in cell lines that are sensitive to 66 and $67 .{ }^{94}$

A specimen of Fascaplysinopsis sp. from Palau contained the anti-inflammatory sesterterpene palauolol (88), which was accompanied by known compounds palauolide (89) and fascaplysin (66). ${ }^{95}$ Palauolol (88) was chemically recognised as being a secondary alcohol that upon dehydration yields its known congener palauolide (89). Compound 89 was first obtained as an antimicrobial sesterterpene from a three sponge association collected in Palau which was later identified as Fascaplysinopsis sp. ${ }^{95,96}$ Two closely related lipodepsipeptides, taumycins A and B (90 and 91) have been isolated from an undescribed Fascaplysinopsis species from Madagascar. ${ }^{97}$ Taumycins A and B (90 and 91) have the same 12-membered oxodepsipeptide ring system. Compound 90 shows cytotoxic activity against the human UT-7 leukemic cell line. In 2008, Bishara et al. reported three nitrogenous macrolides salarin A and B (92 and 93) and tulearin A (94) from the Madagascan sponge Fascaplysinopsis sp. ${ }^{98}$ A year later, the relative 
configuration of 92 was determined by X-ray diffraction. ${ }^{99}$ In 2010, the structure of salarin B (93) was later revised to have a tetrahydrofuran ring system instead of the 16,17-diol. ${ }^{100}$ Tulearin A (94) carries a naturally rare carbamate ester, and its relative and absolute configurations were determined by X-ray diffraction and modified Mosher's methods respectively. ${ }^{101}$ Both 92 and 94 exhibit cytotoxicity toward leukemia cell lines. ${ }^{98}$

Shortly thereafter, Bishara et al. reported salarin C (95) from the same Madagascan sponge. ${ }^{102}$ Compound 95 is closely related to 92 and 93 and upon air oxidation, 95 was found to transform to $\mathbf{9 2}$. Compound 95 was found to inhibit cell proliferation of human leukemic and murine cell lines. Tulearins B and C (96 and 97) were reported in 2009 followed by tausalarin C (98), a novel bismacrolide. ${ }^{99,101}$ It is suggested that tausalarin $\mathrm{C}$ (98) is assembled from salarin A and pretaumycin A. Salarins D-J (99-105) were reported from the same Madagascan sponge by Bishara et al. in 2010, and are closely related to salarins A-C. ${ }^{100}$ Salarins D (99), E (100), H (103) and J (105) showed significant cytotoxic activity against human leukemia cells, while salarins F (101) and I (104) were inactive. There are striking structural similarities of these metabolites to known metabolites of microbial and fungal origin*, suggesting that marine microorganisms may be the true sources of these metabolites. ${ }^{105-107}$
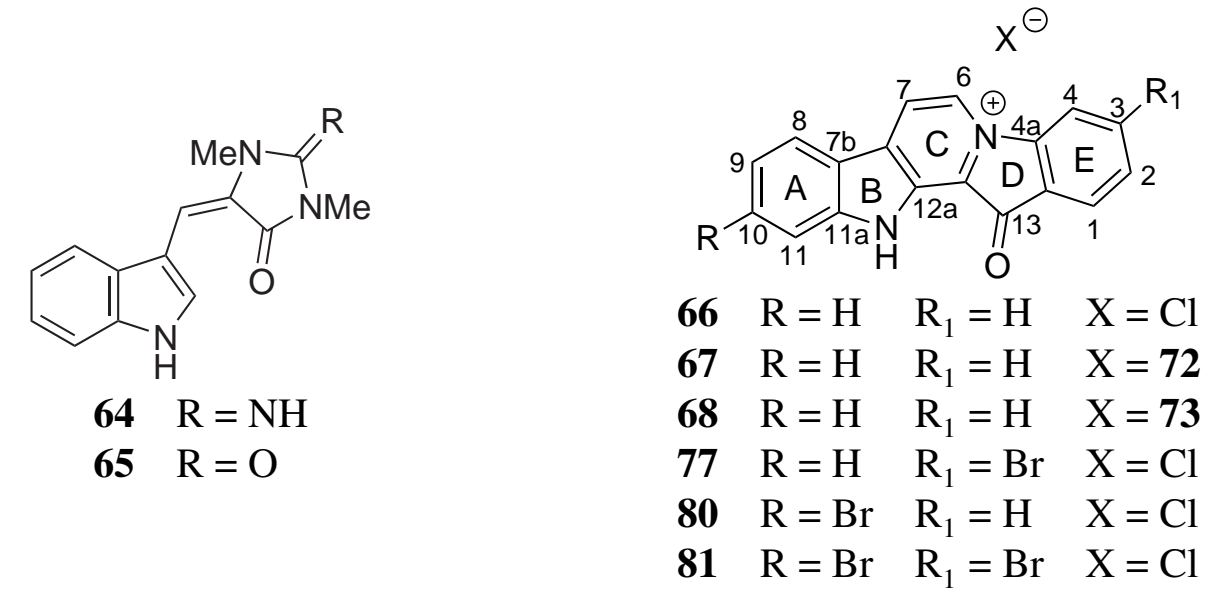

*e.g. Madangolide and laingolide A, metabolites from the cyanobacteria Lyngbya bouillonii. ${ }^{103,104}$ 


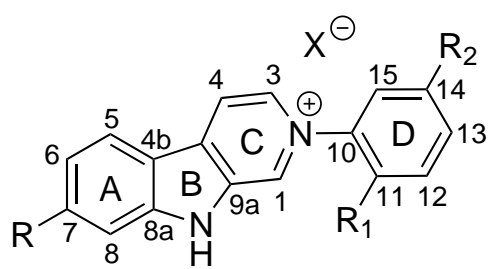

$69 \mathrm{R}=\mathrm{H} \quad \mathrm{R}_{1}=\mathrm{COOMe} \quad \mathrm{R}_{2}=\mathrm{H} \quad \mathrm{X}=\mathbf{7 3}$

$70 \mathrm{R}=\mathrm{H} \quad \mathrm{R}_{1}=\mathrm{COOMe} \quad \mathrm{R}_{2}=\mathrm{H} \quad \mathrm{X}=\mathbf{7 2}$

$78 \quad \mathrm{R}=\mathrm{H} \quad \mathrm{R}_{1}=\mathrm{COOMe} \quad \mathrm{R}_{2}=\mathrm{Br} \quad \mathrm{X}=\mathrm{HCO}_{2}^{-}$

$\begin{array}{llll}79 & \mathrm{R}=\mathrm{H} & \mathrm{R}_{1}=\mathrm{COO}^{-} & \mathrm{R}_{2}=\mathrm{Br}\end{array}$

$83 \mathrm{R}=\mathrm{Br} \quad \mathrm{R}_{1}=\mathrm{COOMe} \quad \mathrm{R}_{2}=\mathrm{Br} \quad \mathrm{X}=\mathrm{Cl}$

$84 \mathrm{R}=\mathrm{H} \quad \mathrm{R}_{1}=\mathrm{OH} \quad \mathrm{R}_{2}=\mathrm{H} \quad \mathrm{X}=\mathrm{Cl}$

$85 \mathrm{R}=\mathrm{H} \quad \mathrm{R}_{1}=\mathrm{OH} \quad \mathrm{R}_{2}=\mathrm{Br} \quad \mathrm{X}=\mathrm{Cl}$

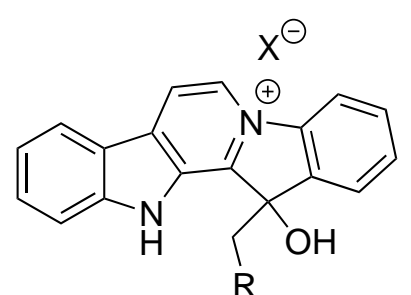

$71 \mathrm{R}=\mathrm{COCH}_{3} \quad \mathrm{X}=\mathbf{7 2}$

$82 \mathrm{R}=\mathrm{COOH} \quad \mathrm{X}=\mathrm{Cl}$<smiles>[R]C1(Br)CC[C@@H](C)[C@H](CC/C(C)=C/CC/C(C)=C/CC/C(=C/C(=O)O)C(=O)O)C1C</smiles>

$72 \mathrm{R}=\mathrm{R}_{1}=\mathrm{H}$

$73 \mathrm{R}=\mathrm{R}_{1}=\mathrm{O}$

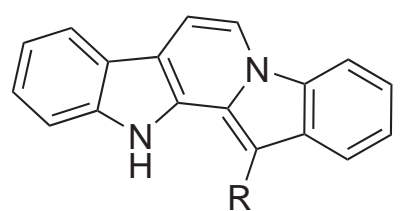

$74 \mathrm{R}=\mathrm{COCOOMe}$

$75 \mathrm{R}=\mathrm{CHO}$

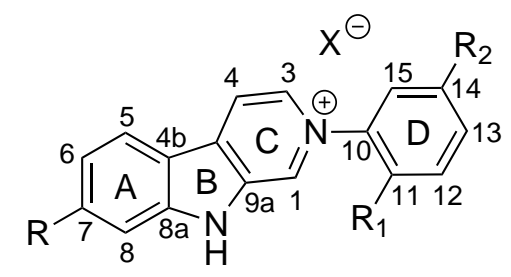

$76 \mathrm{R}=\mathrm{COCOCH}_{3} \quad \mathrm{R}_{1}=\mathrm{H}$

$86 \mathrm{R}=\mathrm{COCOCH}_{3} \quad \mathrm{R}_{1}=\mathrm{Br}$

$87 \mathrm{R}=\mathrm{COCHO} \quad \mathrm{R}_{1}=\mathrm{Br}$

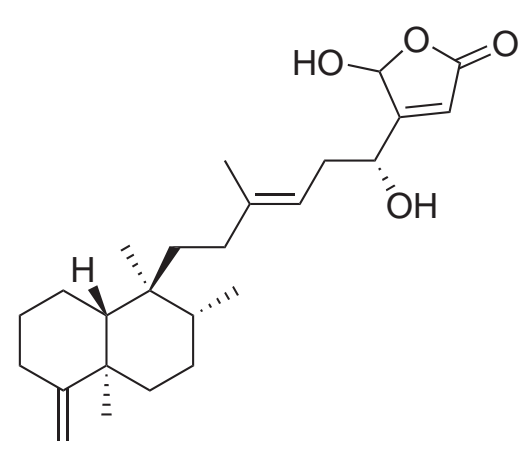

88

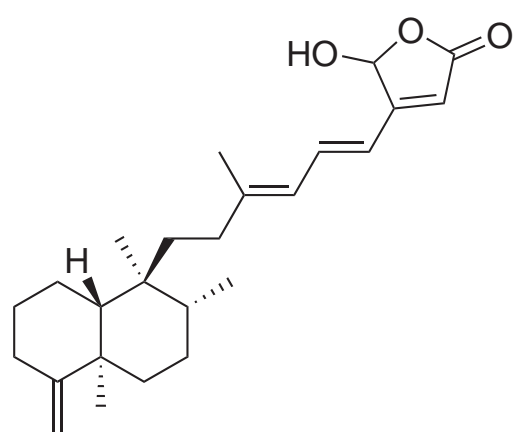

89

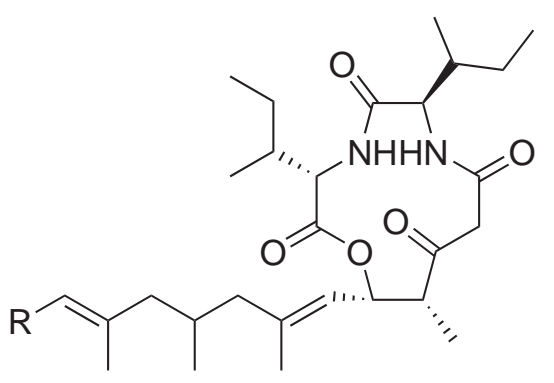

$90 \mathrm{R}=$

$91 \mathrm{R}=\mathrm{COOH}$ 


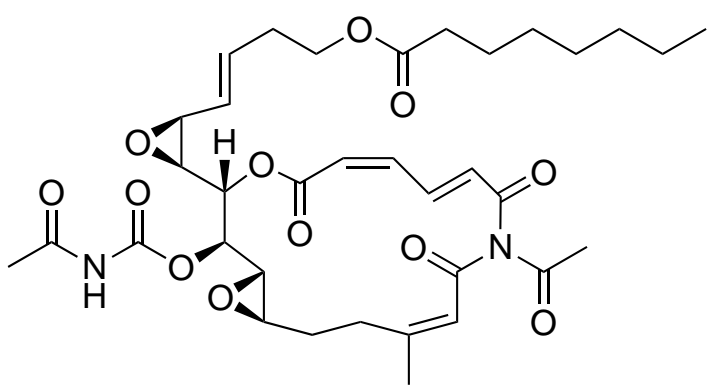

92

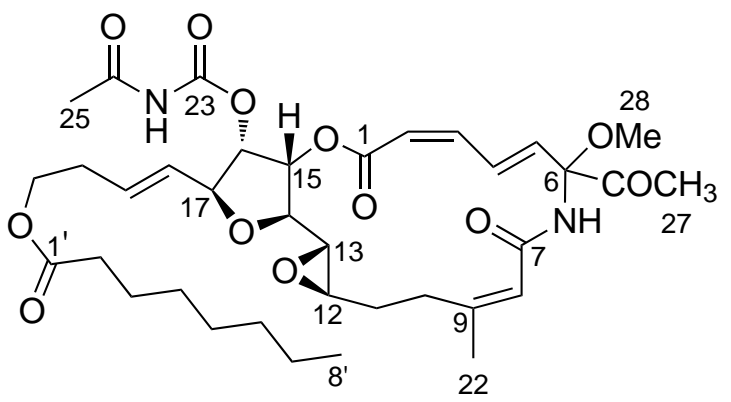

93

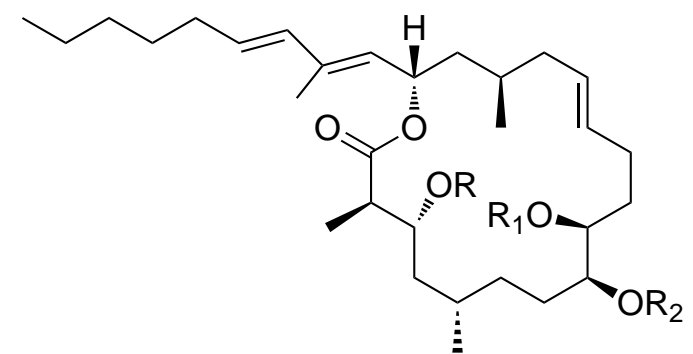

$94 \mathrm{R}=\mathrm{H} \quad \mathrm{R}_{1}=\mathrm{H} \quad \mathrm{R}_{2}=\mathrm{CONH}_{2}$

$96 \mathrm{R}=\mathrm{CONH}_{2} \quad \mathrm{R}_{1}=\mathrm{H} \quad \mathrm{R}_{2}=\mathrm{CONH}_{2}$

$97 \mathrm{R}=\mathrm{H} \quad \mathrm{R}_{1}=\mathrm{H} \quad \mathrm{R}_{2}=\mathrm{H}$

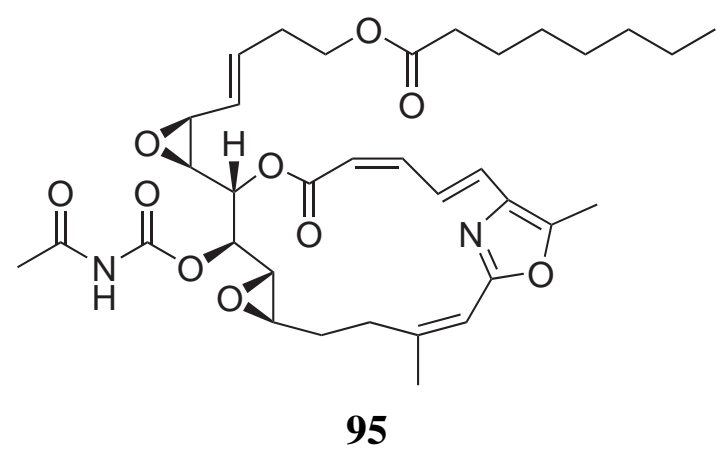

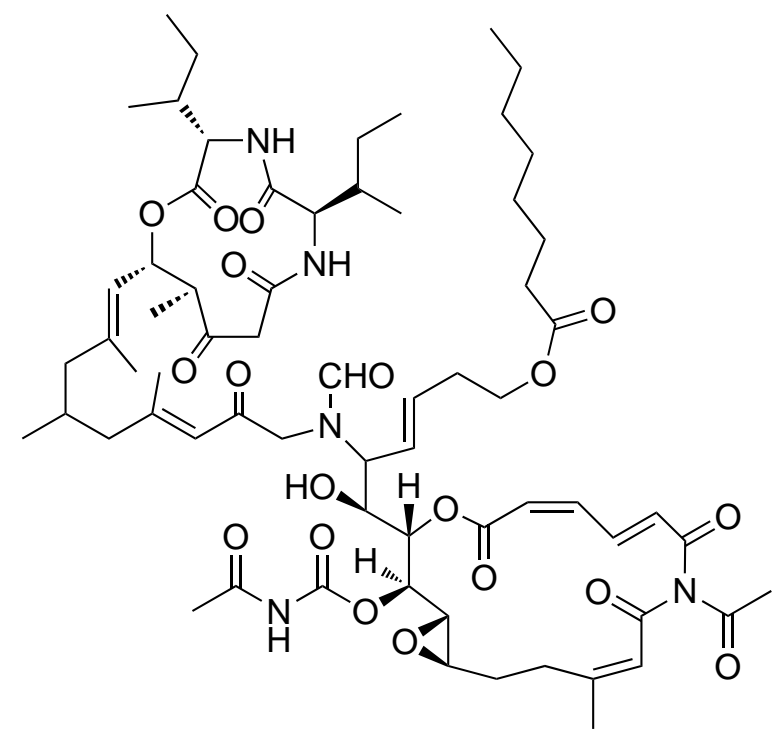

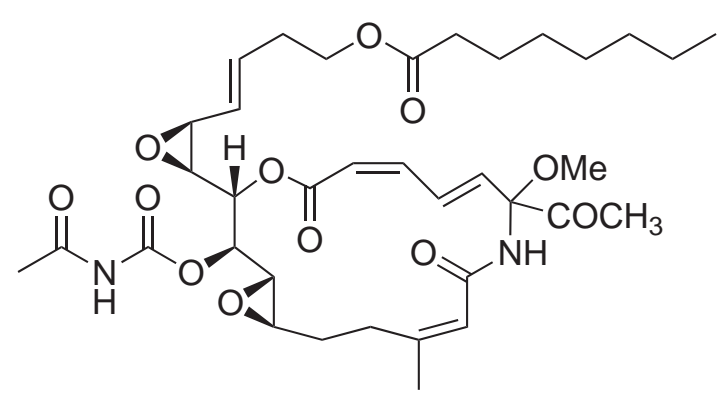

99 


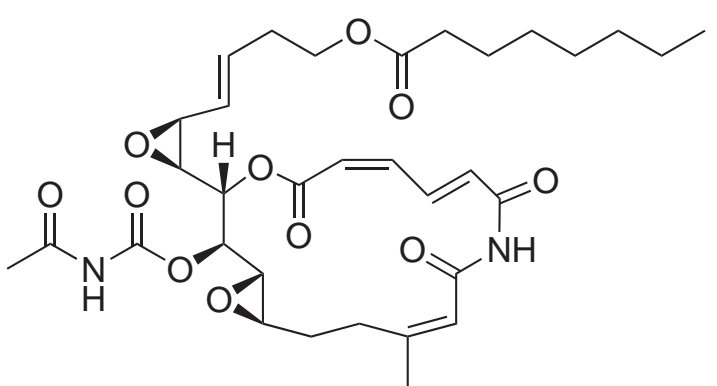

100

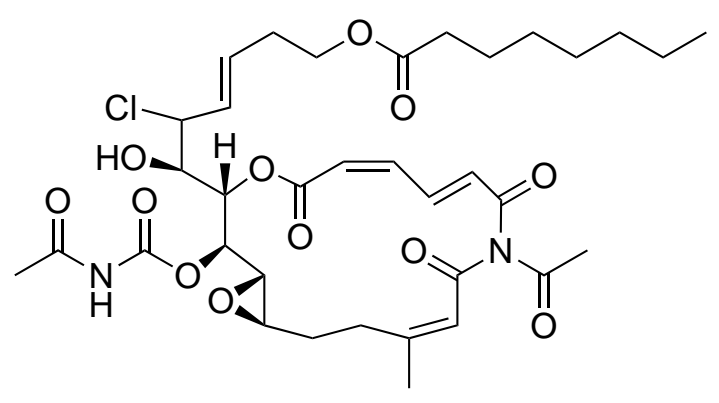

102

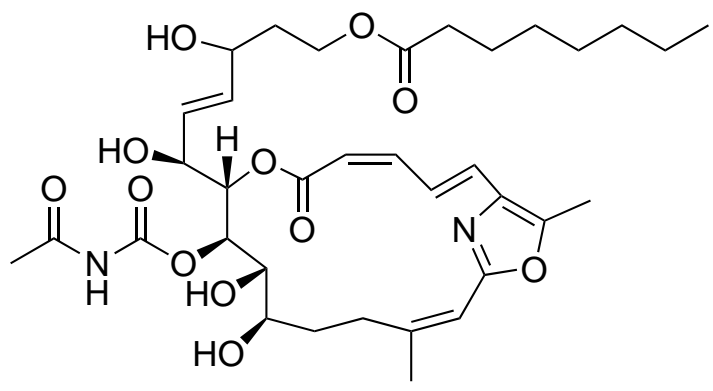

104
Cl<smiles></smiles>

101

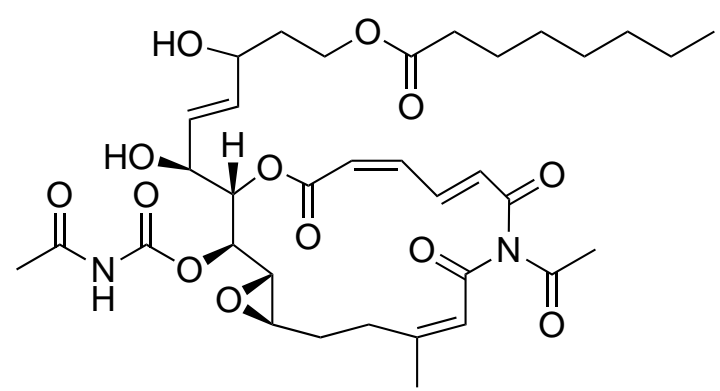

103

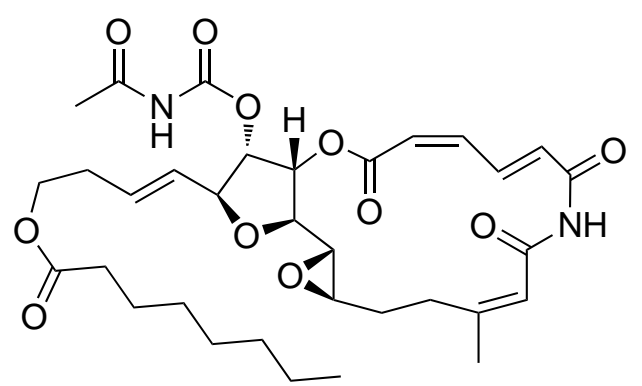

105 


\subsection{Isolation}

A sponge identified as Fascaplysinopsis sp. was collected from an underwater cave off the southwestern coast of 'Eua, Tonga. The sponge was extracted twice in $\mathrm{MeOH}$ and the methanolic extracts were cyclic loaded onto a column of reversed-phase PSDVB beads. The resin was batch eluted with increasing amounts of $\mathrm{Me}_{2} \mathrm{CO} / \mathrm{H}_{2} \mathrm{O}$. NMR examination of the eluted fractions showed that the interesting signals were confined in the $30 \%$ and $80 \% \mathrm{Me}_{2} \mathrm{CO} / \mathrm{H}_{2} \mathrm{O}$ fractions. Further chromatographic steps employing bench-top normal-phase chromatography followed by reversed-phase HPLC (depicted in Scheme 5.1) led to the isolation of three known compounds, homofascaplysin A (43), isodehydroisoluffariellolide (44), and luffariellolide (45), along with two novel compounds, isoluffariellolide (46) and 1-O-methylisoluffariellolide (47). Homofascaplysin A (43) and isodehydroluffariellolide (44) were originally isolated in 1991 from the Fijian sponge Fascaplysinopsis reticulata, ${ }^{91}$ while luffariellolide (45) was first obtained from the Palauan sponge Luffariella sp. ${ }^{108}$ Compound $\mathbf{4 3}$ was isolated in this study without the sesterterpenoid anion.<smiles></smiles>

43<smiles>CC1=C(CC/C(C)=C/CC/C(C)=C/CCC2=CCOC2=O)C(=O)CCC1</smiles>

44<smiles>CC1=C(CC/C(C)=C/CC/C(C)=C/CCC2=CC(=O)O[C@@H]2O)C(C)(C)CCC1</smiles>

45 


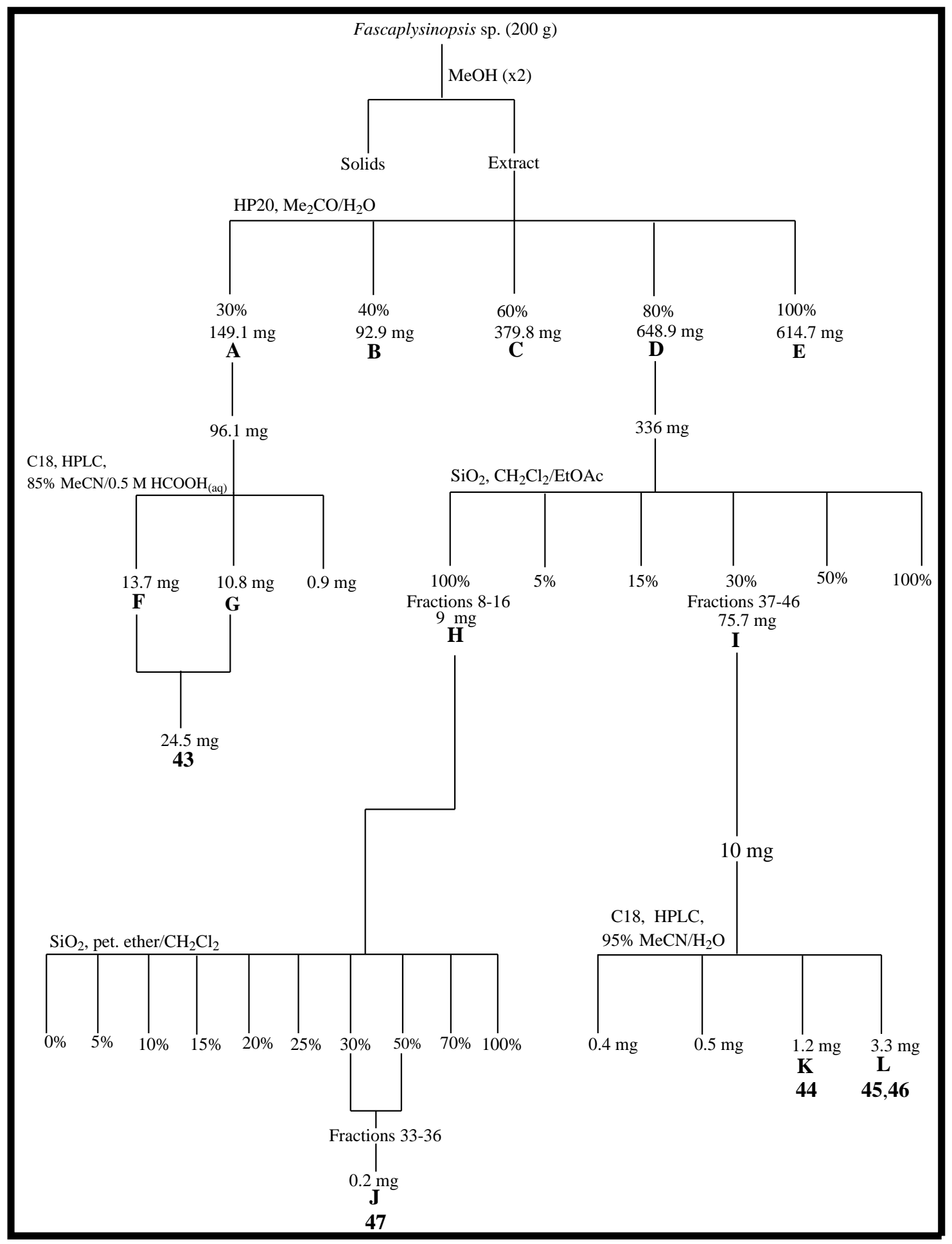

Scheme 5.1. Isolation of homofascaplysin A (43), isodehydroluffariellolide (44), luffariellolide (45), isoluffariellolide (46) and 1- $O$-methylisoluffariellolide (47) from Fascaplysinopsis sp. collected from 'Eua, Tongatapu. 


\subsection{Isoluffariellolide}

Isoluffariellolide (46) was isolated as stable, light yellowish oil. Accurate mass measurement of the molecular formula $\mathrm{C}_{25} \mathrm{H}_{38} \mathrm{O}_{3}$ was determined for $\mathbf{4 6}$ by HRESIMS with the $[\mathrm{M}+\mathrm{Na}]^{+}$pseudomolecular ion at $m / z 409.3471(\Delta 0.1 \mathrm{ppm})$, requiring seven double bond equivalents. Despite repeated chromatography, compound 46 was always accompanied by a small amount of compound $45(\sim 18 \%)$ as illustrated in the ${ }^{1} \mathrm{H}$ NMR spectrum (see Appendix B). ${ }^{1} \mathrm{H}$ NMR resonances were observed for $\mathrm{H}-1$ and $\mathrm{H}$ 3 attributed to 45 ( $\delta_{\mathrm{H}} 6.00$ and 5.85 ppm respectively) and $\mathrm{H}-1$ and $\mathrm{H}-2$ attributed to 46 ( $\delta_{\mathrm{H}} 6.84$ and $6.10 \mathrm{ppm}$ respectively).

The ${ }^{13} \mathrm{C}$ NMR spectrum of $\mathbf{4 6}$ contained 24 distinct resonances while the ${ }^{1} \mathrm{H}$ NMR spectrum accounted for 37 of the 38 protons. An HSQC experiment confirmed the attachment of 37 of these protons to carbon, indicating the presence of one exchangeable proton. All 25 carbon resonances were identified through interpretation of the ${ }^{1} \mathrm{H}$ and HSQC NMR spectra; five methyls $\left(\delta_{\mathrm{C}} 16.2 ; 16.3 ; 20.0,28.8,28.8\right)$, nine methylenes $\left(\delta_{\mathrm{C}} 19.7 ; 25.3 ; 25.7 ; 26.7 ; 28.1 ; 32.9 ; 39.8 ; 40.0 ; 40.4\right)$, three olefinic methines $\left(\delta_{\mathrm{C}} 122.5\right.$; $123.5 ; 143.6)$, one oxymethine $\left(\delta_{\mathrm{C}} 96.9\right)$, and seven quartenary carbons $\left(\delta_{\mathrm{C}} 35.1 ; 127.1\right.$; $136.4 ; 137.2 ; 137.3 ; 138.1 ; 171.8)$ (Table 5.3).

COSY correlations between methylene $\mathrm{H}_{2}-18\left(\delta_{\mathrm{H}} \quad 1.90 ; \delta_{\mathrm{C}} \quad 32.9\right)$ and methylene $\mathrm{H}_{2}$ $17\left(\delta_{\mathrm{H}} \quad 1.55 ; \delta_{\mathrm{C}} 19.7\right)$, and between $\mathrm{H}_{2}-17$ and methylene $\mathrm{H}_{2}-16\left(\delta_{\mathrm{H}} 1.40 ; \delta_{\mathrm{C}} \quad 40.0\right)$ established the methylene chain $\mathrm{C}-16$ to $\mathrm{C}-18$. HMBC correlations from $\mathrm{H}_{2}-18$ to $\mathrm{C}$ 16 and $\mathrm{C}-17$, in conjunction with $\mathrm{HMBC}$ correlations from $\mathrm{H}_{2}-16$ to $\mathrm{C}-17$ and $\mathrm{C}-18$ confirmed these connections (Figure 5.2).
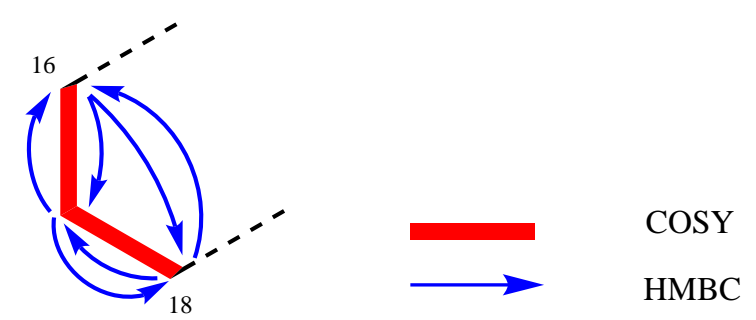

Figure 5.2. COSY and HMBC correlations establishing connectivity of C-16 to C-18 of isoluffariellolide (46). 
Analysis of the $\mathrm{HMBC}$ spectrum revealed that $\mathrm{H}_{2}-18$ showed three other correlations to $\mathrm{C}-14\left(\delta_{\mathrm{C}}\right.$ 137.2), $\mathrm{C}-19\left(\delta_{\mathrm{C}} 127.1\right)$, and $\mathrm{CH}_{3}-20\left(\delta_{\mathrm{H}} \quad 1.60 ; \delta_{\mathrm{C}} 20.0\right)$. The singlet ${ }^{1} \mathrm{H}$ signal of $\mathrm{CH}_{3}-20$ indicates attachment to a double bond at a quartenary carbon. This was confirmed by HMBC correlations from $\mathrm{H}_{3}-20$ to C-14, C-18, and C-19. An HMBC correlation from $\mathrm{H}_{2}-17$ to $\mathrm{C}-19$ firmly established the connectivity between $\mathrm{C}-18$ and C-19, as well as the attachment of $\mathrm{CH}_{3}-20$ to $\mathrm{C}-19$. A six-proton methyl singlet at $\mathrm{CH}_{3}$ $21 / \mathrm{CH}_{3}-22\left(\delta_{\mathrm{H}} \quad 0.99 ; \delta_{\mathrm{C}} 28.8\right)$ was assigned as a gem-dimethyl pair, connected to the alkyl quaternary carbon C-15 which in turn is adjacent to C-14 and C-16 on either side. An HMBC correlation observed from $\mathrm{H}-16$ to $\mathrm{C}-14$ and C-15, confirmed this connection. The HMBC correlations from $\mathrm{H}_{3}-21 / 22$ to $\mathrm{C}-14, \mathrm{C}-15$, and $\mathrm{C}-16$ suggested that substructure A (depicted in Figure 5.3), is a trimethylcyclohexenyl ring, which is also encountered in luffariellolide, the mokupalides and the luffariolides. ${ }^{108-110}$
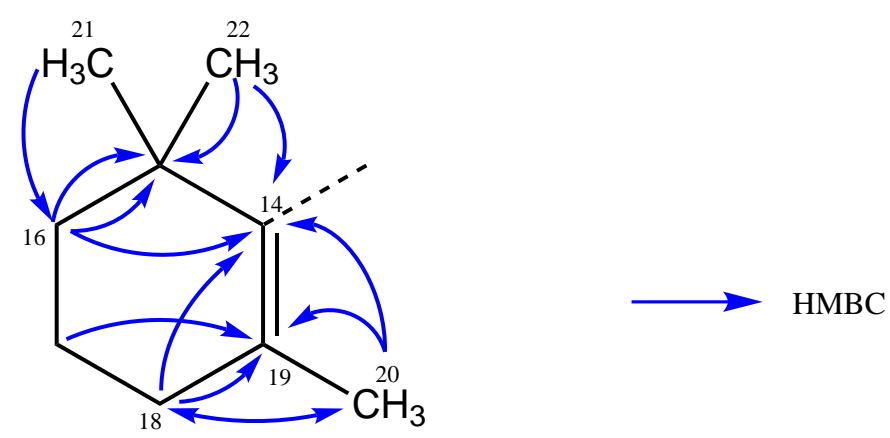

Figure 5.3. HMBC correlations establishing connectivity of the trimethylcyclohexenyl ring system, substructure A, of isoluffariellolide (46).

Methylene protons $\mathrm{H}_{2}-13\left(\delta_{\mathrm{H}} 2.04 ; \delta_{\mathrm{C}} 28.1\right)$ showed HMBC correlations to C-14 and C-19, indicating the connection between C-13 and C-14. Vicinal couplings between $\mathrm{H}_{2}$ 13 and methylene protons $\mathrm{H}_{2}-12\left(\delta_{\mathrm{H}} 1.99 ; \delta_{\mathrm{C}} 40.4\right)$ extended the fragment further and provided the connection between $\mathrm{C}-12$ and $\mathrm{C}-13$. HMBC correlations observed from $\mathrm{H}_{2}$ 13 to $\mathrm{C}-12$ and $\mathrm{H}_{2}-12$ to $\mathrm{C}-13$ confirmed this connection. Analysis of the HMBC spectrum showed two correlation from $\mathrm{H}_{2}-12$ to a quartenary olefinic carbon $\mathrm{C}-11\left(\delta_{\mathrm{C}} 136.4\right)$ and to a olefinic methine $\mathrm{CH}-10\left(\delta_{\mathrm{H}} 5.10 ; \delta_{\mathrm{C}}\right.$ 123.5) suggesting a trisubstituted double bond. The methyl singlet $\mathrm{CH}_{3}-23\left(\delta_{\mathrm{H}} 1.63 ; \delta_{\mathrm{C}} 16.2\right)$ must be connected to $\mathrm{C}-11$, which is supported by a HMBC correlation from $\mathrm{H}_{3}-23$ to $\mathrm{C}-11$. HMBC correlations from $\mathrm{H}_{3}-23$ to $\mathrm{C}-12$ and $\mathrm{C}-10$ confirmed this connection, which was further supported by a long-range COSY correlation between $\mathrm{H}-10$ to $\mathrm{H}_{3}$-23, establishing substructure B (Figure 5.4). 


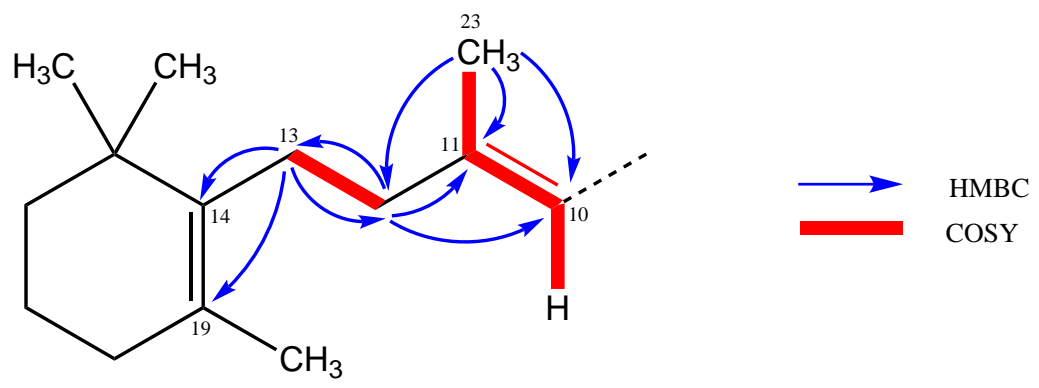

Figure 5.4. COSY and HMBC correlations establishing connectivity of C-10 to C-13, substructure B, of isoluffariellolide (46).

A similar substructure was revealed in the COSY spectrum from a correlation between the two methylenes $\mathrm{CH}_{2}-9\left(\delta_{\mathrm{H}} \quad 2.08 ; \delta_{\mathrm{C}} \quad 26.7\right)$ and $\mathrm{CH}_{2}-8\left(\delta_{\mathrm{H}} \quad 2.00 ; \delta_{\mathrm{C}} \quad 39.8\right)$ as the two methylenes show vicinal coupling to each other. This connection was confirmed by HMBC correlations from $\mathrm{H}_{2}-9$ to $\mathrm{C}-8$ and $\mathrm{H}_{2}-8$ to C-9. The assignment of C-10 and C-9 as adjacent carbons was supported by $\mathrm{HMBC}$ correlations from $\mathrm{H}_{2}-9$ to $\mathrm{C}-10$ and $\mathrm{C}-11$, and $\mathrm{H}-10$ to C-9, strong correlations from $\mathrm{H}_{2}-8$ to an olefinic carbon $\mathrm{C}-7\left(\delta_{\mathrm{C}} 137.3\right)$ and to an olefinic methine $\mathrm{CH}-6\left(\delta_{\mathrm{H}} 5.10 ; \delta_{\mathrm{C}} 122.5\right)$. Again a trisubstituted double bond was established using $\mathrm{HMBC}$ correlations from $\mathrm{CH}_{3}-24\left(\delta_{\mathrm{H}} 1.61 ; \delta_{\mathrm{C}} 16.3\right)$ to $\mathrm{CH}-6, \mathrm{C}-7$ and C-8, establishing substructure C (Figure 5.5).

Due to spectral overlap, NOE enhancements were of limited utility in determining the geometry of the double bonds. Fortunately, methyl groups $\left(\mathrm{CH}_{3}-23\right.$ and $\left.\mathrm{CH}_{3}-24\right)$ on the trisubstituted double bonds show characteristic NMR shifts: $\delta_{\mathrm{H}}<1.6$ and $\delta_{\mathrm{C}}<20$ for the $E$, and $\delta_{\mathrm{H}}>1.6$ and $\delta_{\mathrm{C}}>20$ for $Z$ geometry. ${ }^{111}$ Thus, the methyl groups revealed the double bonds $\Delta_{6,7}$ and $\Delta_{10,11}$ to both have $E$ geometry.

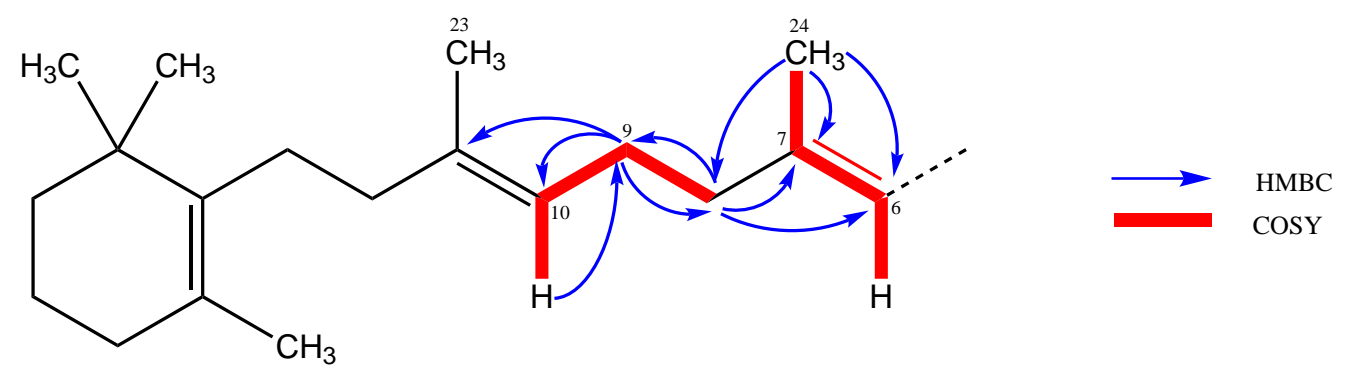

Figure 5.5. COSY and HMBC correlations establishing connectivity of C-6 to C-9, substructure $\mathrm{C}$, of isoluffariellolide (46).

COSY correlations between two methylenes $\mathrm{CH}_{2}-5\left(\delta_{\mathrm{H}} \quad 2.26 ; \delta_{\mathrm{C}}\right.$ 25.7) and $\mathrm{CH}_{2}-4$ $\left(\delta_{\mathrm{H}} 2.35 ; \delta_{\mathrm{C}} 25.3\right.$ ), and HMBC correlations from $\mathrm{H}_{2}-5$ to $\mathrm{C}-4$ and $\mathrm{H}_{2}-4$ to $\mathrm{C}-5$, indicated 
the linkage between C-5 and C-4. An HMBC correlation from $\mathrm{H}_{2}-5$ to C-6 and C-7 was evident, confirming the connectivity of C-5 and C-6. Analysis of the HMBC spectrum showed extra correlations from $\mathrm{H}_{2}-4$ to three carbons: a carbonyl C-25 ( $\left.\delta_{\mathrm{C}} 171.7\right)$, an olefinic carbon C-3 $\left(\delta_{\mathrm{C}} 138.1\right)$, and an olefinic methine carbon $\mathrm{CH}-2\left(\delta_{\mathrm{H}} 6.84 ; \delta_{\mathrm{C}} 143.6\right)$, suggesting that C-4 is adjacent to C-3. The deshielded shift of carbon C-25 suggested the presence of an $\alpha, \beta$-unsaturated lactone unit. The HMBC correlations from $\mathrm{H}-2$ to C-25, C-3 and CH-1 ( $\delta_{\mathrm{H}} \quad 6.10 ; \delta_{\mathrm{C}}$ 96.9), in conjunction with the HMBC correlation from $\mathrm{H}-1$ to $\mathrm{C}-25$ and $\mathrm{C}-3$ formed a $\gamma$-hydroxybutenolide ring, which accounted for the last remaining three double bond equivalents. The $\alpha, \beta$-unsaturated carbonyl shields the $\alpha$-carbon and deshields the $\beta$-carbon. This places $\mathrm{CH}-2$ at the $\beta$-position, and the alkyl attachment at C-3. An excellent confirmation of this assumption arose from the homoallylic relationship between $\mathrm{H}-1$ and $\mathrm{H}_{2}-4$, illustrated by an ${ }^{1} \mathrm{H}-{ }^{1} \mathrm{H}$ COSY long range correlation. This established substructure D (depicted in Figure 5.6), as an $\alpha$-substituted$\gamma$-hydroxybutenolide ring.
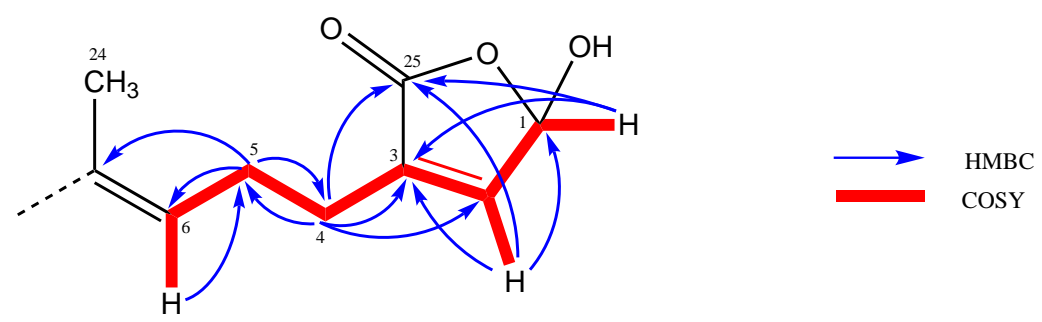

Figure 5.6. COSY and HMBC correlations establishing connectivity of the $\alpha$-sustituted- $\gamma$-hydroxybutenolide ring, substructure $\mathrm{D}$, of isoluffariellolide (46).

The NMR data for the $\gamma$-hydroxybutenolide ring for isoluffariellolide (46) was compared to that of luffariellolide (45) ${ }^{108}$ and dictyodendrillin C (106) $)^{112}$ to ensure the correct structural isomer of 46 was assigned (Table 5.2). In 46 and 106, an $\alpha$-substituted- $\alpha, \beta$ butenolide ring is proposed, while 45 contains a $\beta$-substituted- $\alpha, \beta$-butenolide ring. The substitution position affects the proton chemical shifts of the olefinic methine proton and the oxymethine proton. In 46, the olefinic methine proton appears at $\delta_{\mathrm{H}} 6.84$ ppm compared to $\delta_{\mathrm{H}} 5.85 \mathrm{ppm}$ in $\mathbf{4 5}$. The oxymethine proton in $\mathbf{4 6}$ appears at 6.10 ppm compared to $6.01 \mathrm{ppm}$ in 45. Thus, the substitution on the $\alpha$-position of the $\gamma$ hydroxybutenolide ring, as opposed to the $\beta$-position, causes the downfield shift of the H-2 and H-1 resonances in the ${ }^{1} \mathrm{H}$ NMR spectrum. This also has a great effect on the chemical shifts of the olefinic methine carbon and the quartenary olefinic carbon. The 
olefinic methine carbon in $\mathbf{4 6}$ appears at $\delta_{\mathrm{C}} 138.1 \mathrm{ppm}$ and resonates at $\delta_{\mathrm{C}} 117.0 \mathrm{ppm}$ in $\mathbf{4 5}$, whilst in $\mathbf{4 5}$, the quartenary olefinic carbon appears at $\delta_{\mathrm{C}} 169.9 \mathrm{ppm}$ compared to $\delta_{\mathrm{C}} 138.1 \mathrm{ppm}$ in 46. Both carbons showed dramatically changed chemical shifts. Thus, the substitution point on the $\gamma$-hydroxybutenolide ring system greatly affected the ${ }^{1} \mathrm{H}$ and ${ }^{13} \mathrm{C}$ chemical shift for the $\alpha$ - and $\beta$-position. The ${ }^{1} \mathrm{H}$ and ${ }^{13} \mathrm{C}$ NMR data for 46 were consistent with that for 106, supporting the substitution at the $\alpha$-position. Therefore the structure of isoluffariellolide is given as $\mathbf{4 6}$ with NMR data presented in Table 5.3.

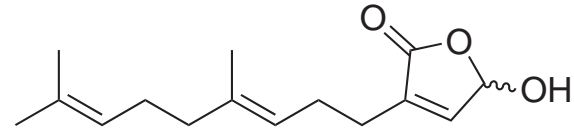

106

Table 5.2. Comparison of the ${ }^{1} \mathrm{H}$ and ${ }^{13} \mathrm{C}$ NMR chemical shifts $\left(\mathrm{CDCl}_{3}\right)$ of the $\gamma$-hydroxybutenolide ring of luffariellolide (45), isoluffariellolide (46), and dictyodendrillin $\mathrm{C}$ (106).<smiles>O=C1C=CC(O)C1O</smiles>

45

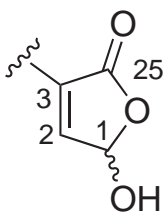

46<smiles>CC1=CC(O)OC1=O</smiles>

106

\begin{tabular}{cccccccc}
\hline & \multicolumn{3}{c}{${ }^{1} \mathrm{H}$} & & & \multicolumn{3}{c}{${ }^{13} \mathrm{C}$} \\
\cline { 2 - 4 } \cline { 6 - 8 } Position & $\mathbf{4 5}$ & $\mathbf{4 6}$ & $\mathbf{1 0 6}$ & & $\mathbf{4 5}$ & $\mathbf{4 6}$ & $\mathbf{1 0 6}$ \\
\hline 1 & 6.01 & 6.10 & 6.07 & & 99.5 & 96.9 & 96.7 \\
2 & & 6.84 & 6.83 & & 169.9 & 143.6 & 143.6 \\
3 & 5.85 & & & & 117.0 & 138.1 & 137.7 \\
$25\left(15^{\dagger}\right)$ & & & & & 171.9 & 171.7 & $171.1^{\dagger}$ \\
\hline
\end{tabular}

†Assigned as carbon 25 (C-15). 


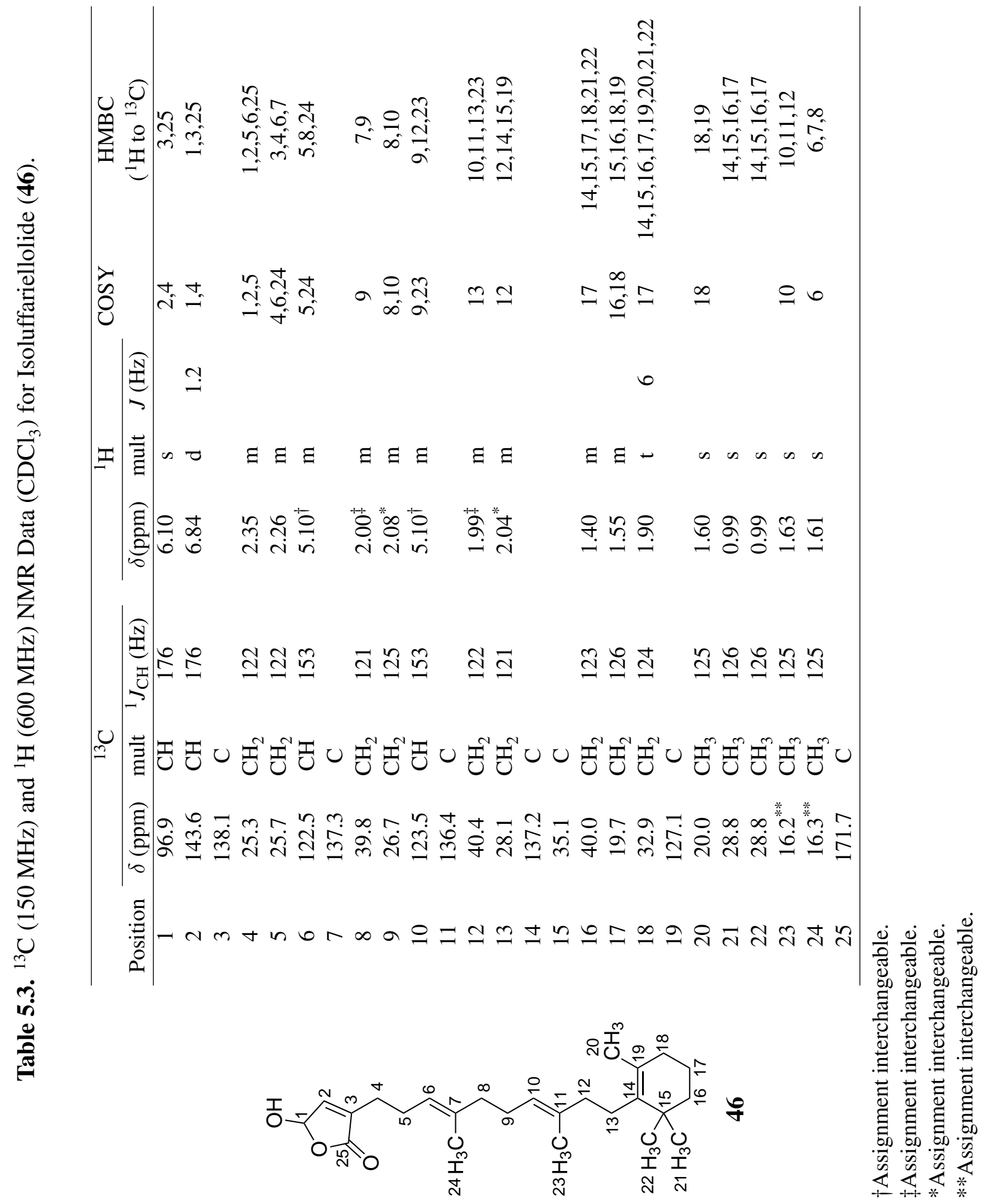




\subsection{1-O-Methylisoluffariellolide}

1-O-Methylisoluffariellolide (47) was isolated as a light yellowish oily residue. Positiveion mode HRESIMS analysis of $\mathbf{4 7}$ showed a characteristic pseudomolecular ion peak at $m / z 423.2867\left([\mathrm{M}+\mathrm{Na}]^{+}, \Delta 0.0 \mathrm{ppm}\right)$, indicative of a molecular formula of $\mathrm{C}_{26} \mathrm{H}_{40} \mathrm{O}_{3}$, requiring seven double-bond equivalents. The molecular formula for compound $\mathbf{4 7}$ differs from luffariellolide (45) and isoluffariellolide (46) by a $\mathrm{CH}_{2}$ unit, supporting the gain of one oxymethyl group as indicated by the appearance of a deshielded methyl resonance $\left(\delta_{\mathrm{H}} 3.55, \delta_{\mathrm{C}} 57.0\right)$ in the NMR spectra of 47.

The ${ }^{13} \mathrm{C}$ NMR spectrum contained 26 distinct carbon resonances while the ${ }^{1} \mathrm{H}$ NMR spectrum accounted for all 40 protons, which a multiplicity-edited HSQC experiment confirmed were all attached to carbon. A detailed analysis of the ${ }^{13} \mathrm{C}, \mathrm{HSQC}$ and HMBC NMR spectra of 1-O-methylisoluffariellolide (47) (Table 5.4) assigned all 26 carbons in the molecule; five methyls $\left(\delta_{\mathrm{C}} 16.2 ; 16.3 ; 20.0,28.8,28.8\right)$, nine methylenes $\left(\delta_{\mathrm{C}} 19.7\right.$; $25.5 ; 25.6 ; 26.7 ; 28.1 ; 32.9 ; 39.8 ; 40.0 ; 40.4)$, three olefinic methines $\left(\delta_{\mathrm{C}} 122.5 ; 123.5\right.$; 142.2), one oxymethyl ( $\delta_{\mathrm{C}}$ 57.0), one oxymethine $\left(\delta_{\mathrm{C}}\right.$ 102.6), and seven quartenary carbons $\left(\delta_{\mathrm{C}} 35.1,127.1 ; 136.3 ; 137.2 ; 137.3 ; 138.5 ; 171.6\right)$.

The structure of $\mathbf{4 7}$ was elucidated in a similar fashion to isoluffariellolide (46), beginning at the methylene chain in the trimethylcyclohexenyl ring. A series of sequential COSY correlations were observed starting from methylene proton resonances of $\mathrm{CH}_{2}$ $18\left(\delta_{\mathrm{H}} 1.90 ; \delta_{\mathrm{C}} 32.9\right)$ to a second methylene proton $\mathrm{H}_{2}-17\left(\mathrm{C}-17: \delta_{\mathrm{C}} 19.7 ; \delta_{\mathrm{H}} 1.55\right)$, and between $\mathrm{H}_{2}-17$ to third methylene proton $\mathrm{H}_{2}-16\left(\delta_{\mathrm{H}} 1.40 ; \delta_{\mathrm{C}} 40.0\right)$ established the methylene chain C-16 to C-18. This was confirmed through two and three bond HMBC correlations between $\mathrm{CH}_{2}-16, \mathrm{CH}_{2}-17$, and $\mathrm{CH}_{2}-18$ (Figure 5.7).
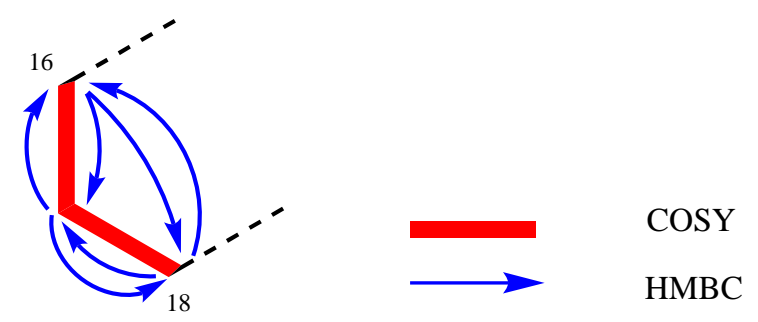

Figure 5.7. COSY and HMBC correlations establishing connectivity of C-18 to C-16 of 1-O-methylisoluffariellolide (47). 
Further analysis of the HMBC spectrum showed another three correlations from $\mathrm{H}_{2}-16$ to quartenary $s p^{3}$ carbon $\mathrm{C}-15\left(\delta_{\mathrm{C}} 35.1\right)$, olefinic quaternary carbon C-14 $\left(\delta_{\mathrm{C}} 137.3\right)$, and gem-dimethyl carbons $\mathrm{CH}_{3}-21 / 22\left(\delta_{\mathrm{H}} \quad 0.99 ; \delta_{\mathrm{C}} 28.8\right)$. The gem-dimethyl singlet showed strong HMBC correlations to C-14, C-15, C-16, suggested that they are connected to the alkyl quaternary carbon (C-15), which in turn is adjacent to C-16 and C-14 on the other sides. The methylene protons $\mathrm{H}_{2}-18$ also exhibited HMBC correlations to C-14 and C-19 ( $\delta_{\mathrm{C}}$ 127.1), suggesting $\mathrm{C}-19$ placement on the other side, establishing the presence of a fully substituted double bond. An HMBC correlation from methyl singlet proton $\mathrm{CH}_{3}$ $20\left(\delta_{\mathrm{H}} 1.60 ; \delta_{\mathrm{C}} 20.0\right)$ to $\mathrm{C}-19$ confirmed this connection and established substructure A (depicted in Figure 5.8), as a trimethylcyclohexenyl ring which is also observed in isoluffariellolide (46).

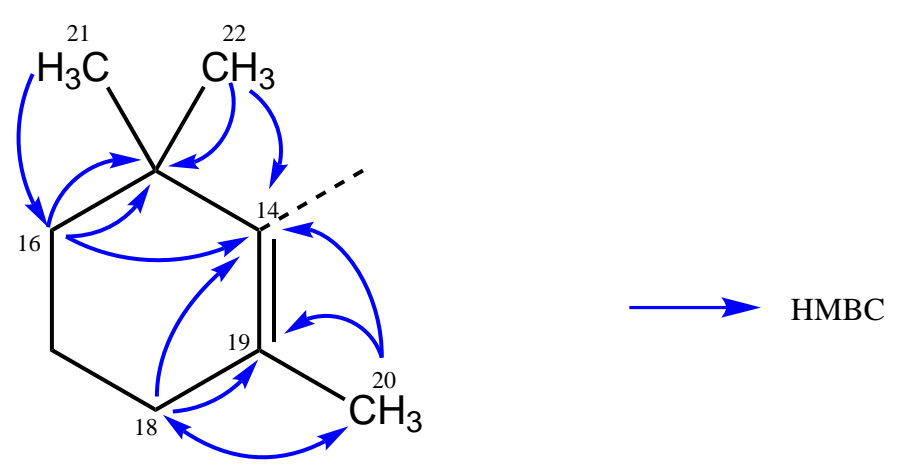

Figure 5.8. HMBC correlations establishing connectivity of the trimethylcyclohexenyl ring moiety, substructure A, of 1-O-methylisoluffariellolide (47).

HMBC correlations observed from $\mathrm{H}_{2}-13\left(\delta_{\mathrm{H}} 2.04 ; \delta_{\mathrm{C}} 28.1\right)$ to C-14 and C-19, indicating the connection between C-13 and C-14. Observation of a COSY correlation between methylene proton $\mathrm{H}_{2}-13$ and methylene protons of $\mathrm{CH}_{2}-12\left(\delta_{\mathrm{H}} 1.98 ; \delta_{\mathrm{C}} 40.4\right)$ extended the partial structure, shown in Figure 5.10. An HMBC correlation from $\mathrm{H}_{2}-13$ to C12 and from $\mathrm{H}_{2}-12$ to $\mathrm{C}-13$, confirmed this assignment between $\mathrm{C}-13$ to $\mathrm{C}-12$. Further HMBC correlations from $\mathrm{H}_{2}-12$ to olefinic carbon $\mathrm{C}-11\left(\delta_{\mathrm{C}} 136.3\right)$ and olefinic methine $\mathrm{CH}-10\left(\delta_{\mathrm{H}} 5.10 ; \delta_{\mathrm{C}} 123.5\right)$, suggested the presence of another trisubsituted double bond (C-11 to C-10). The methyl singlet carbon $\mathrm{CH}_{3}-23\left(\delta_{\mathrm{H}} 1.63 ; \delta_{\mathrm{C}} 16.2\right)$ placement on the double bond was established through HMBC correlations from methyl proton $\mathrm{H}_{3}-23$ to $\mathrm{C}-11$ and $\mathrm{C}-10$. An HMBC correlation from olefinic methine proton $\mathrm{H}-10$ to $\mathrm{C}-23$ established the connection between C-11 and C-10, and the adjacent of C-23 to the nonprotonated olefinic carbon C-11. Analysis of the COSY spectrum showed long range 
coupling from olefinic methine proton $\mathrm{H}-10$ to methyl proton $\mathrm{H}_{3}-23$ that confirmed this connection (Figure 5.9).

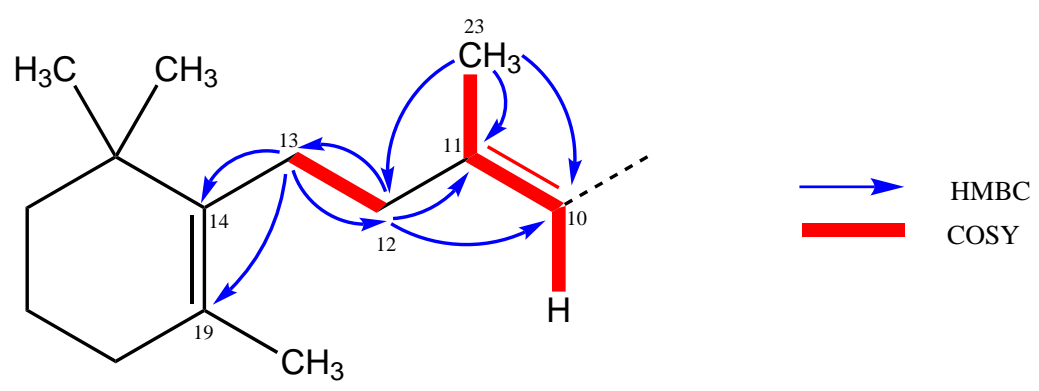

Figure 5.9. $\mathrm{COSY}$ and $\mathrm{HMBC}$ correlations establishing connectivity of $\mathrm{C}-9$ to $\mathrm{C}-6$ of 1-O-methylisoluffariellolide (47).

Two further methylenes $\left(\mathrm{C}-9: \delta_{\mathrm{H}} \quad 2.06 ; \delta_{\mathrm{C}} \quad 26.7, \mathrm{C}-8: \delta_{\mathrm{H}} \quad 2.00 ; \delta_{\mathrm{C}} \quad 39.8\right)$ were placed next to the double bond (C-11 to C-10) based on COSY correlations observed from $\mathrm{H}$ 10 to $\mathrm{H}_{2}-9$ and from $\mathrm{H}_{2}-9$ to $\mathrm{H}_{2}-8$. Together with an $\mathrm{HMBC}$ correlation from olefinic methine proton $\mathrm{H}-10$ to $\mathrm{C}-9$, this confirmed the placement of adjacent $\mathrm{C}-10$ and $\mathrm{C}$ 9. An HMBC correlation from $\mathrm{H}_{2}-9$ to $\mathrm{C}-8$ and $\mathrm{H}_{2}-8$ to $\mathrm{C}-9$ confirmed the connection between $\mathrm{C}-9$ and C-8. The methylene proton $\mathrm{H}_{2}-8$ showed extra HMBC correlations to two carbons; non-protonated olefinic carbon C-7 $\left(\delta_{\mathrm{C}}\right.$ 137.2) and olefinic methine carbon CH-6 $\left(\delta_{\mathrm{H}} 5.09 ; \delta_{\mathrm{C}} 122.5\right)$. Unsurprisingly, the structure was unveiling itself as another isopropene unit with HMBC and COSY correlations establishing the presence of another trisubstituted double bond. The methyl singlet proton $\mathrm{H}_{3}-24\left(\delta_{\mathrm{H}} 1.60 ; \delta_{\mathrm{C}} 16.3\right)$ showed HMBC correlations to C-6 and C-7 which confirmed this assignment. This established substructure B, as depicted in Figure 5.10.

Due to spectral overlap, NOE enhancements were of limited utility in determining the geometry of the double bonds. The methyl groups $\left(\mathrm{CH}_{3}-23\right.$ and $\left.\mathrm{CH}_{3}-24\right)$ on the isolated trisubstituted double bonds show characteristic NMR shifts: $\delta_{\mathrm{H}}<1.6$ and $\delta_{\mathrm{C}}<20$ for the $E$, and $\delta_{\mathrm{H}}>1.6$ and $\delta_{\mathrm{C}}>20$ for $Z$ geometry. ${ }^{111}$ Based on this, and the similarity of chemical shifts with related compounds (same in 46), the double bonds $\Delta_{6,7}$ and $\Delta_{10,11}$ were assigned as $E$. 


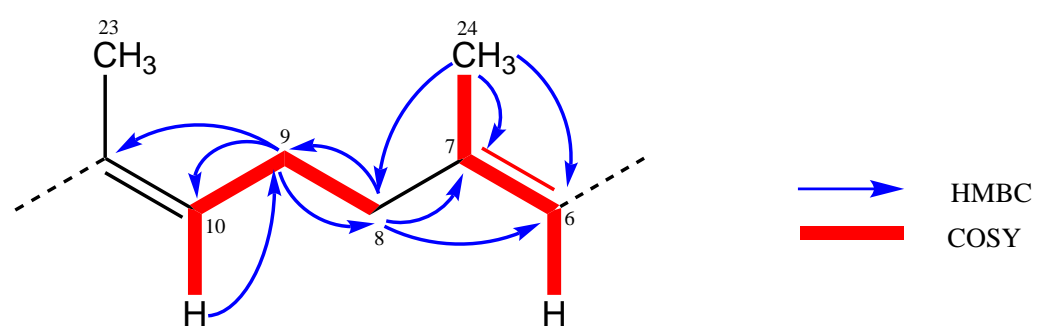

Figure 5.10. COSY and HMBC correlations establishing connectivity of C-13 to C-6, substructure $\mathrm{B}$, of 1-O-methylisoluffariellolide (47).

The substructures $\mathrm{A}$ and $\mathrm{B}$ accounted for four double bond equivalents suggesting the compound contained a ring system and two double bonds. COSY correlations observed between two methylenes $\mathrm{CH}_{2}-5\left(\delta_{\mathrm{H}} 2.25 ; \delta_{\mathrm{C}} 25.6\right)$ and $\mathrm{CH}_{2}-4\left(\delta_{\mathrm{H}} 2.33 ; \delta_{\mathrm{C}} 25.5\right)$, and HMBC correlation from $\mathrm{H}_{2}-5$ to C-4 and $\mathrm{H}_{2}-4$ to C-5 indicated the placement between C-5 and C-4. HMBC correlations from H-5 to C-7 and C-6 was evident, confirming the connectivity of C-5 and C-6. The methylene proton $\mathrm{H}_{2}-5$ and $\mathrm{H}_{2}-4$ showed HMBC correlations to an olefinic carbon $\mathrm{C}-3\left(\delta_{\mathrm{C}} 138.5\right)$, establishing the connectivity between C-3 and C-4.

Further analysis of the HMBC spectrum showed correlations from $\mathrm{H}_{2}-4$ to an ester carbonyl carbon $\mathrm{C}-25\left(\delta_{\mathrm{C}} 171.6\right)$ and olefinic methine carbon $\mathrm{CH}-2\left(\delta_{\mathrm{H}} 6.76 ; \delta_{\mathrm{C}} 142.2\right)$. HMBC correlations from olefinic methine proton $\mathrm{H}-2$ to C-25, C-3, CH-1 $\left(\delta_{\mathrm{H}} 5.72\right.$; $\delta_{\mathrm{C}}$ 102.6), $\mathrm{CH}_{2}-4$, and from oxymethine proton $\mathrm{H}-1$ to $\mathrm{C}-25$ and $\mathrm{C}-3$, suggested the presence of an $\alpha, \beta$-butenolide ring. A series of COSY correlations between $\mathrm{H}-2, \mathrm{H}-1$ and $\mathrm{H}_{2}-4$ placed C-4 at the $\alpha$-position of the butenolide. The butenolide ring system accounted for the last remaining three double bond equivalents. HMBC correlations from oxymethyl proton $\mathrm{H}_{3}-26$ to $\mathrm{C}-1$, placed an oxymethyl at the $\gamma$-position of the butenolide ring instead of a hydroxyl group as observed in $\mathbf{4 6}$ (Figure 5.11).

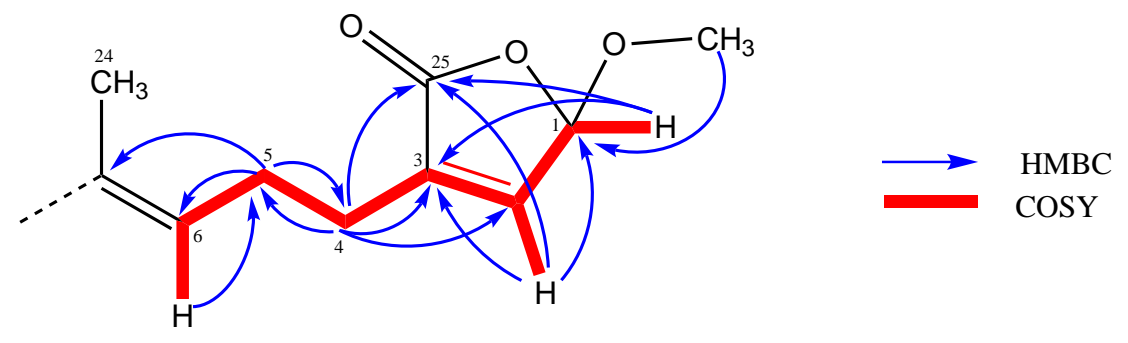

Figure 5.11. COSY and HMBC correlations establishing connectivity of the $\alpha$-substituted- $\gamma$-methylbutenolide ring, substructure $\mathrm{C}$, of 1-O-methylisoluffariellolide (47). 
The presence of an upfield non-protonated olefinic carbon and a downfield olefinic methine, suggested that it is an $\alpha$-substituted butenolide ring. The NMR data for the butenolide ring for 1-O-isoluffariellolide (47) was also compared to that of isoluffariellolide (46), 25-O-methylluffariellolide (107) $)^{113}$ and 1- $O$-ethylhyrtiolide (108) $)^{114}$ to ensure the correct structural isomer of $\mathbf{4 7}$ was assigned (Table 5.4). Firstly comparing $\mathbf{4 6}$ and 47, the only signficant difference in the ${ }^{13} \mathrm{C}$ NMR spectrum is $\mathrm{C}-1$, which is shifted downfield by approximately $6 \mathrm{ppm}$ in 47 . This change in chemical shift is consistent with carbon substitution of the free hydroxyl group. Compound $\mathbf{4 7}$ is substituted on the $\alpha$-position (same in $\mathbf{4 6}$ and 108) while $\mathbf{1 0 7}$ is a $\beta$-substituted butenolide ring. In 47, the olefinic methine proton appears at $\delta_{\mathrm{H}} 6.76 \mathrm{ppm}$ and resonates at $\delta_{\mathrm{H}} 5.91 \mathrm{ppm}$ in 107. The substitution on the $\alpha$-position of the butenolide ring, as opposed to the $\beta$ position, caused the downfield shift of the olefinic methine in the ${ }^{1} \mathrm{H}$ NMR spectrum. The substitution position also affected the chemical shifts of the olefinic methine carbon and non-protonated olefinic carbon. In 47, the olefinic methine carbon appears at $\delta_{\mathrm{C}} 142.2$ ppm and resonates at $\delta_{\mathrm{C}} 118.8 \mathrm{ppm}$ in $\mathbf{1 0 7}$, whilst in 107, the non-protonated olefinic carbon appears at $\delta_{\mathrm{C}} 170.0 \mathrm{ppm}$ compared to $\delta_{\mathrm{C}} 138.5 \mathrm{ppm}$ in 47 . The substitution of the butenolide ring does not affect the chemical shifts of $\mathrm{C}-1$ and $\mathrm{C}-25$. The ${ }^{1} \mathrm{H}$ and ${ }^{13} \mathrm{C} \mathrm{NMR}$ data for $\mathbf{4 7}$ were consistent with that of $\mathbf{1 0 8}$, supporting the substitution on the $\alpha$-position (C-3). Therefore the structure of 1-O-methylisoluffariellolide is given as 47 with NMR data presented in Table 5.4.

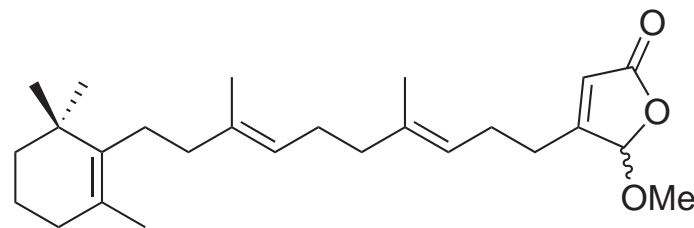

107

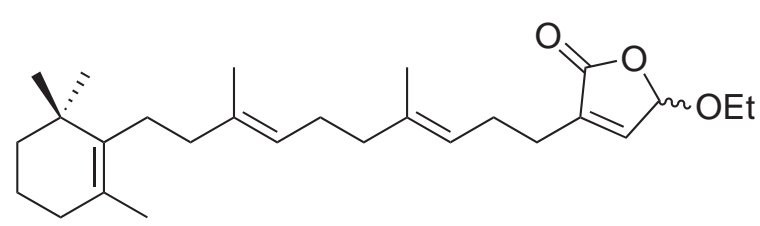

108 
Table 5.4. Comparison of the ${ }^{1} \mathrm{H}$ and ${ }^{13} \mathrm{C}$ NMR Chemical Shifts of the Butenolide Ring of Isoluffariellolide (46), 1-O-Methylisoluffariellolide (47), 25-O-Methylluffariellolide (107), and 1- $O$-Ethylhyrtiolide (108).<smiles>CC1=CC(O)O[C+]C1=O</smiles>

46

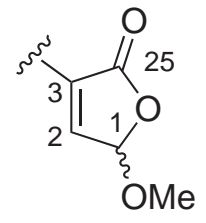

47<smiles></smiles>

107<smiles>CCO[C@@H]1C=C(C)C(=O)O1</smiles>

108

\begin{tabular}{cccccccccc}
\hline & \multicolumn{4}{c}{${ }^{1} \mathrm{H}$} & & \multicolumn{3}{c}{${ }^{13} \mathrm{C}$} \\
\cline { 2 - 5 } \cline { 7 - 9 } Position & $\mathbf{4 6}$ & $\mathbf{4 7}$ & $\mathbf{1 0 7}$ & $\mathbf{1 0 8}$ & & $\mathbf{4 6}$ & $\mathbf{4 7}$ & $\mathbf{1 0 7}$ & $\mathbf{1 0 8}$ \\
\hline 1 & 6.10 & 5.72 & 5.78 & 5.78 & & 96.9 & 102.6 & 106.3 & 101.5 \\
2 & 6.84 & 6.76 & & 6.75 & & 143.6 & 142.2 & 170.0 & 142.2 \\
3 & & & 5.91 & & & 138.1 & 138.5 & 118.8 & 138.1 \\
25 & & & & & & 171.7 & 171.6 & 172.0 & 171.5 \\
\hline
\end{tabular}

Compounds 46, 47 and 108 were recorded in $\mathrm{CDCl}_{3}$ whilst 107 was recorded in $\mathrm{CD}_{3} \mathrm{OD}$. 


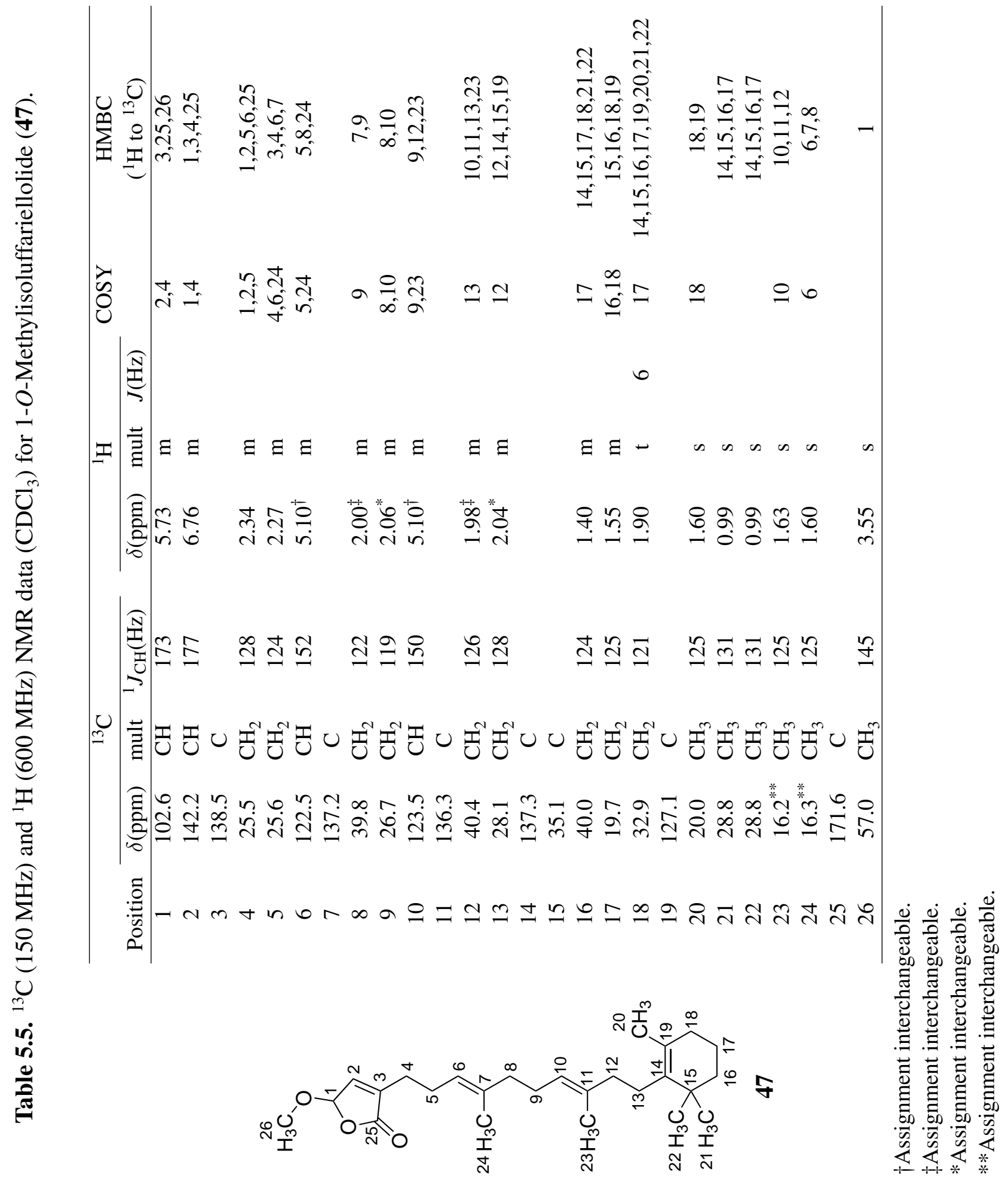




\subsection{Biological Activity}

Isodehydroluffariellolide (44), isoluffariellolide (46) and 1-O-methylisoluffariellolide (47) were submitted for cytotoxicity testing at the School of Biological Sciences, VUW. They were tested in a 48 hour MTT assay against HL-60 (leukemia) cells. Compounds 44, 46 and 47 were found to be moderately cytotoxic with $\mathrm{IC}_{50}$ values in the micromolar range (12.21 $\mu \mathrm{M}, 29.63 \mu \mathrm{M}$ and $5.09 \mu \mathrm{M}$ respectively). ${ }^{86}$

\subsection{Related Compounds}

Many primary and secondary metabolites are derived from terpenes, all biosynthesised from the five-carbon isoprene building units. ${ }^{115}$ Structural modification of these isoprene units leads to a diverse range of derivatives with unique chemical structures and biological properties. Triterpenoids were the first terpenoids reported from marine resources and since then a vast array of derivatives have been documented. Marine sponges have been identified as one of the prime resources of sesterterpenes. ${ }^{116}$

Manoalide (109) is the parent compound of a series of marine sponge metabolites belonging to the sesterterpene class and probably the most well known of all sesterterpene sponge metabolites. Manoalide (109) was originally isolated by Scheuer et al. in 1980 from the sponge Luffariella variabilis collected in Palau. ${ }^{117}$ One year later, Scheuer et al. reported three additional related metabolites from the same Palauan sponge, secomanoalide (110), (E)-neomanoalide (111) and (Z)-neomanoalide (112). ${ }^{118}$ All four compounds (109-112) exhibit antibiotic activity. ${ }^{119}$ Later, marine sponges of the family Thorectidae, including species of the genera Hyrtios, ${ }^{114,120,121}$ Cacospongia, ${ }^{122,123}$ Thorectandra, ${ }^{124,125}$ Fasciospongia, ${ }^{126-129}$ Luffariella, ${ }^{108,110,118,130-140}$ Aplysinopsis, ${ }^{141}$ and Acanthodendrilla, ${ }^{113}$ were also found to be rich sources of novel bioactive sesterterpenoids closely related to $\mathbf{1 0 9}$.

Early studies into the pharmocology of $\mathbf{1 0 9}$ revealed an irreversible inhibition of phospholipase $\mathrm{A}_{2} \cdot{ }^{142,143}$ Subsequently, many related metabolites with PLA 2 inhibitory 
activity were also reported, which attracted scientific interest to study the structureactivity relationships (SAR) of $\mathbf{1 0 9}$ to understand both PLA $_{2}$ function and mechanism of action in the whole cell. ${ }^{108,144-150}$ Several studies revealed the contribution of various functional groups incorporated in $\mathbf{1 0 9}$ and its analogues, such as the $\gamma$-hydroxybutenolide, $\alpha$-hydroxydihydropyran and trimethylcyclohexenyl ring systems, to the efficacy as PLA 2 inhibitors. ${ }^{146,150,151}$

Manoalide-25-monoacetate (113) was reported in 1988 from the marine sponge Thorectandra excavatus. ${ }^{124}$ 24-O-Ethylmanoalide (114) was isolated from Luffariella $\mathrm{cf}$. variabilis collected from the Indian Ocean, ${ }^{140}$ while 24-O-propylmanoalide (115) was obtained from the Palauan sponge L. variabilis. ${ }^{138}$ (4E,6E)-Dehydromanoalide (116) was obtained from the Palauan sponge L. variabilis and showed reduced potency but similar efficacy to that of 109 against bee venom PLA $_{2}\left(\mathrm{IC}_{50}=0.28 \mu \mathrm{M}\right) .{ }^{134,151}$ Two diastereomers of 24$O$-methylmanoalide (117 and 118) and (6Z)-neomanoalide-24,25-diacetate (119) were isolated from a sponge of the genus Luffariella. ${ }^{136}$ Compounds 117 and 118 exhibited antibacterial activity. Four new antibacterial sesterterpenes (120-123) were reported from a marine sponge of the genus Luffariella collected from the Australian Great Barrier Reef. ${ }^{133}$

An investigation of the Fijian sponge F. reticulata led to the isolation of isodehydroluffariellolide (44) and dehydroluffariellolide diacid (72). ${ }^{91}$ Fasciospongide A (124) was obtained from the New Caledonian sponge Fasciospongia sp. ${ }^{126}$ Bioassay-directed separation of an extract of a Thorectandra sp. sponge led to isolation of 16-oxoluffariellolide (125), 16-hydroxyluffariellolide (126), and compound 127, all with phosphatase Cdc25B inhibitory activity. ${ }^{125}$ Compounds 44, 124 and 125 possessed a substituted trimethylcyclohexenone ring moiety instead of a trimethylcyclohexenyl ring system found in $\mathbf{1 0 9}$ and other analogues. Luffariellolide (45) is a sesterterpenoid analogue of $\mathbf{1 1 0}$, which was first reported by Faulkner et al. in 1987 from the Palauan marine sponge Luffariella sp. ${ }^{108}$ In contrast with the irreversible inhibitory action of 109 towards PLA $\mathrm{A}_{2}$, luffariellolide (45) is a slightly less potent, but a partially reversible $\mathrm{PLA}_{2}$ inhibitor, which meant that $\mathbf{4 5}$ became a more preferable anti-inflammatory agent for potential pharmacological investigation. ${ }^{108}$ 
In addition to luffariellolide (45), its 25-O-methyl (107) and 25- $O$-ethyl derivatives (128), five cytotoxic acantholides A-E, were isolated from the Indonesian sponge Acanthodendrilla sp. ${ }^{113}$ Acantholides A (129) and B (also reported as 16-oxo-luffariellolide, 125) possessed both the trimethylcyclohexene and the $\gamma$-hydroxybutenolide moieties. Acantholides D (130) and E (131) are derivatives comprising the 1-acetylcyclopentan-5-ol moiety, and are rare variants for the $\mathrm{C}_{14}-\mathrm{C}_{20}$ segment in this type of linear sesterterpenes thus replacing the trimethylcyclohexenyl ring. Luffariellolide (45) and its 25-O-methyl congener (107), as well as acantholide E (131), were cytotoxic against the mouse lymphoma L5178Y cell line with $\mathrm{ED}_{50}$ values of $3.3,0.7$, and $7.0 \mu \mathrm{g} / \mathrm{mL}$, respectively. Interestingly, these results suggested that the 25-O-methyl group in compound $\mathbf{1 0 7}$ and the stereochemistry of 1-acetylcyclopentan-5-ol in $\mathbf{1 3 1}$ play an important role in the cytotoxicity of the compound. ${ }^{113}$

Luffariolides A-J (132-140), are a related group of sesterterpenoidal analogues, have been isolated from different collections of the Okinawan marine sponge Luffariella sp. ${ }^{110,130,139}$ All luffarieolides exhibited significant cytotoxicity against the murine lymphoma L1210 cell line with $\mathrm{IC}_{50}$ values ranging between 1.1-7.8 $\mu \mathrm{g} / \mathrm{mL}$. Luffariellins A (141) and B (142) were isolated from the marine sponge L. variabilis collected in Palau. ${ }^{131}$ Chemical investigation of the same sponge species collected from the Great Barrier Reef, Australia, yielded three new acetylated compounds, 25-acetoxyluffariellin A (143), 25-acetoxyluffariellin B (144), and 25-acetoxysecomanoalide (145). ${ }^{137}$ Luffariellins C (146) and D (147) were obtained from the nudibranch Chromodoris funerea collected from Palau. ${ }^{152}$ Luffariellins $(\mathbf{1 4 1 - 1 4 4 )}$ are all characterized by the 1-isoproprenyl-2methylcyclopentane ring system replacing the trimethylcyclohexenyl moiety in other manoalide analogs. Despite this difference in chemical structure, luffariellins A (141) and B (142) retain identical functional groups as present in 109 and 110, respectively. Therefore, not surprisingly, each respective pair was shown to have similar antiinflammatory properties to $\mathbf{1 0 9}$ and $\mathbf{1 1 0} .^{131}$

Hyrtiolide (148) and its 1-O-ethyl derivatives (108) were obtained sponge Hyrtios cf. erecta, from Fiji. ${ }^{114}$ Aplysinoplides A-C (149-151) were isolated from the marine sponge Aplysinopsis digitata. ${ }^{141}$ Compounds (149-151) exhibited cytotoxic activity against P388 
mouse leukemia cell lines with $\mathrm{IC}_{50}$ values of $0.45,0.45$, and $11 \mu \mathrm{g} / \mathrm{mL}$, respectively. In a parallel experiment, aplysinoplides A (149) and B (150) did not inhibit bovine pancreas $\mathrm{PLA}_{2}$ at a concentration of $100 \mu \mathrm{M}$, whereas manoalide (109) exhibited a potent activity. These results suggested the important role of the C-24 aldehyde for inhibition of PLA $2 .{ }^{151}$

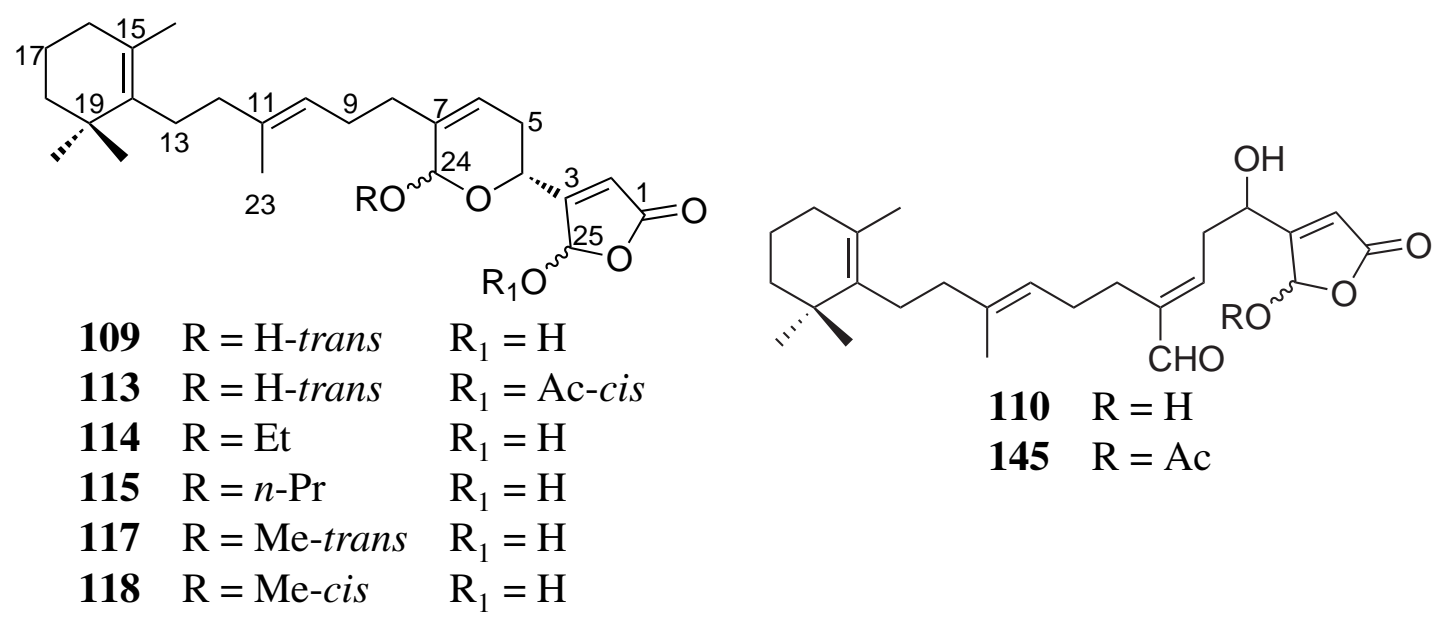

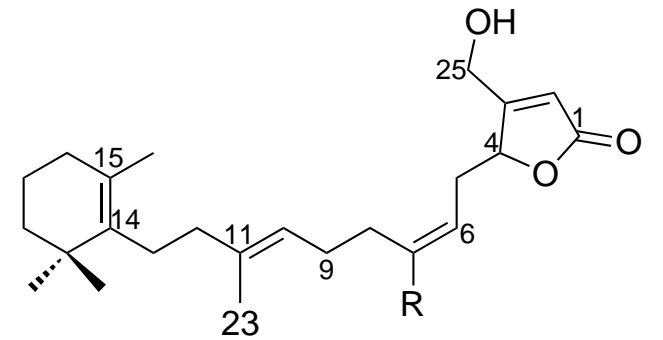

$111 \mathrm{R}=\mathrm{CH}_{2} \mathrm{OH}$

$123 \mathrm{R}=\mathrm{CHO}$<smiles>CC1=C(CC/C(C)=C/CC/C(C=O)=C\C=C\C2=CC(=O)O[C@@H]2O)C(C)(C)CCC1</smiles>

116<smiles>CC1=CC(=O)OC1C/C=C(\CO)CC/C=C(\C)CCC1=C(C)CCCC1(C)C</smiles>

$112 \mathrm{R}=\mathrm{H} \quad \mathrm{R}_{1}=\mathrm{H}$

$119 \mathrm{R}=\mathrm{Ac} \mathrm{R}_{1}=\mathrm{Ac}$

$122 \mathrm{R}=\mathrm{Ac} \quad \mathrm{R}_{1}=\mathrm{H}$

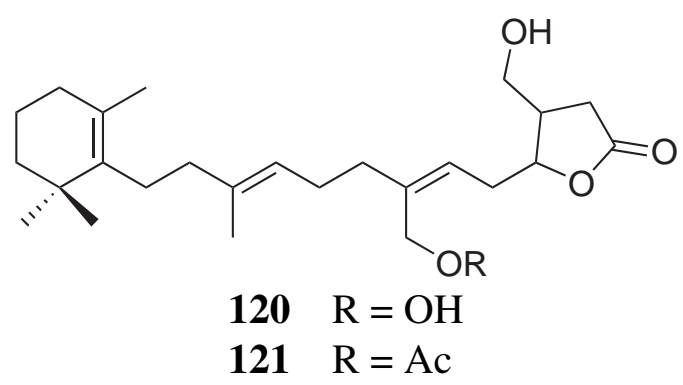


<smiles>CC1=C(CC/C(C)=C/CCC2=CCC(C3=CC(=O)C[C@H]3O)O[C@@H]2O)C(C)(C)CCC1=O</smiles>

124<smiles>CC1=C(CC/C(C)=C/CC/C(C)=C/CC/C(C=O)=C\C(=O)O)C(C)(C)CCC1</smiles>

127

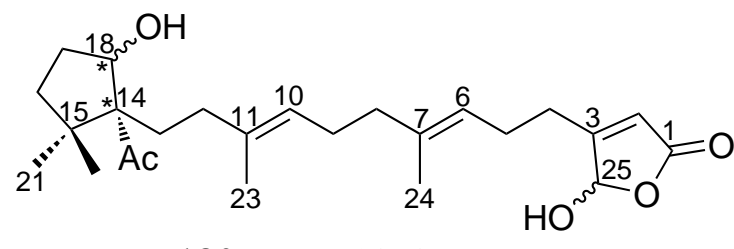

$130 \mathrm{R}=18(\mathrm{OH})$-trans

$131 \mathrm{R}=18(\mathrm{OH})-c i s$

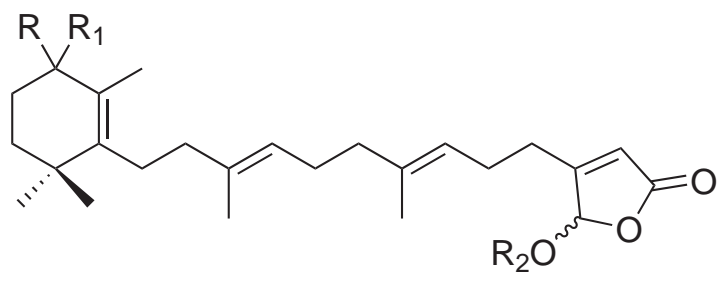

$125 \quad \mathrm{R}=\mathrm{O} \quad \mathrm{R}_{1}=\mathrm{O} \quad \mathrm{R}_{2}=\mathrm{H}$

$126 \quad \mathrm{R}=\mathrm{H} \quad \mathrm{R}_{1}=\mathrm{OH} \quad \mathrm{R}_{2}=\mathrm{H}$

$128 \mathrm{R}=\mathrm{H} \quad \mathrm{R}_{1}=\mathrm{H} \quad \mathrm{R}_{2}=\mathrm{Et}$<smiles>C=C(CCC1=C(C)CCCC1(C)C)[C@H](O)CC/C(C)=C/CCC1=CC(=O)O[C@@H]1O</smiles>

129<smiles>[R]P=[R]O</smiles><smiles>CC1=C(CC/C(C)=C/CC/C(=C/C[C@H](O)C2=CC(=O)OC2)CO)C(C)(C)CCC1</smiles>

133<smiles>[R]C1([R])O[C@H]([C@H]2COC(=O)C2)CC=C1CC/C=C(/C)CCC1=C(C)CCCC1(C)C</smiles>

$135 \mathrm{R}=\mathrm{OH} \quad \mathrm{R}_{1}=\mathrm{H}$

$136 \quad \mathrm{R}=\mathrm{O} \quad \mathrm{R}_{1}=\mathrm{O}$<smiles>CC1=C(CC/C(C)=C/CC/C(=C/CC[C@H]2OC(=O)C[C@H]2CO)CO)C(C)(C)CCC1</smiles>

134<smiles>CC1=C(CC/C(C)=C/CC/C(=C/CC2OC(=O)C=C2CO)CO)C(C)(C)CCC1O</smiles>
137 
<smiles>CC1=C(CC[C@](C)(O)/C=C/C/C(=C/CC2OC(=O)C=C2CO)CO)C(C)(C)CCC1</smiles>

138<smiles>CC1=CCCC(C)(C)C1CC/C(C)=C/CC/C(C=O)=C\C[C@@H](O)C1=CC(=O)O[C@@H]1O</smiles>

140<smiles>[R]C1OC(=O)C=C1C(O)C/C=C(/C=O)CC/C=C(/C)CCC1(C(=C)C)CCC[C@@H]1C</smiles>

$142 \mathrm{R}=\mathrm{OH}$

$144 \mathrm{R}=\mathrm{OAc}$

$147 \mathrm{R}=\mathrm{H}$<smiles>CC1=C(CC/C(C)=C/CC/C(=C\C[C@H](O)C2=CC(=O)O[C@@H]2O)CO)C(C)(C)CCC1</smiles>

150<smiles>CO[C@H]1O[C@H](C2=CC(=O)O[C@@H]2O)CC=C1CC/C=C(\C)CCC1C(C)=CCCC1(C)C</smiles>

139

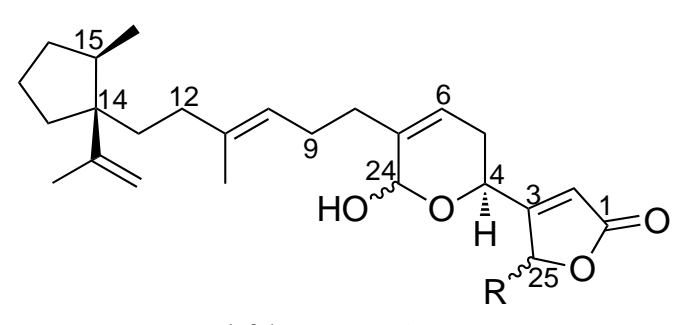

$141 \mathrm{R}=\mathrm{OH}$

$143 \mathrm{R}=\mathrm{OAc}$

$146 \mathrm{R}=\mathrm{H}$<smiles>CC1=C(CC/C(C)=C/CC/C(C)=C/CCC2=CCOC2=O)C(C)(C)CCC1</smiles>

148<smiles>C/C(=C\CC/C(=C/CC1OC(=O)C=C1CO)CO)CCC1C(C)(C)CCCC1(C)O</smiles>

151 


\section{Chapter 6}

\section{Investigation of Sponge from the Order Dictyoceratida}

\subsection{Order Dictyoceratida}

The order Dictyoceratida, which belongs to the class Demospongiae, does not have any silicaceous spicules, which makes taxonomic identification of the dictyoceratid sponges more difficult. Dictyoceratid sponges are tough and flexible, with typical conulose surface, marked by concules or cone-shaped elevations. These sponges often have a marked difference in external and internal pigmentation with a dark exterior and the interior ranging from white, cream, through to pale brown or yellow. The order consists of four families: Dysideidae, Spongiidae, Irciniidae and Thorectidae (Table 6.1). ${ }^{21}$ In terms of chemotaxonomy, the order is characterised by a diverse range of terpenes and very low sterol content. ${ }^{21}$ The taxonomy of the Dictyoceratida has been revised multiple times, ${ }^{21}$ and a full review of the secondary metabolites isolated from dictyoceratid sponges is beyond the scope of this report.

The sponge investigated in this study (shown in Figure 6.1) was a encrusting sponge with upright fingers. The sponge is soft with a slippery texture. It was pale grey on the surface with mid-brownish interior. It contained no silicaceous spicules, and has tentatively been identified as belonging to the order Dictyoceratida.

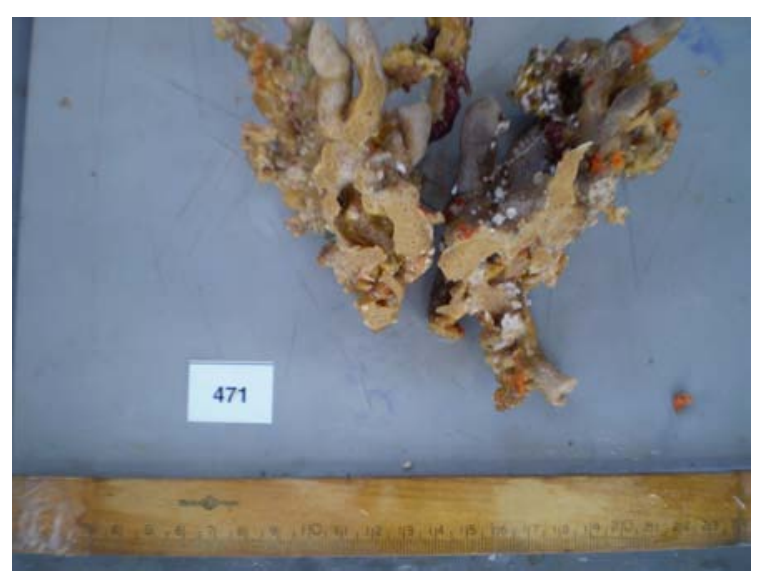

Figure 6.1. Surface photograph of the sponge PTN3_21C. 
Table 6.1. Taxonomic classification of the order Dictyoceratida. ${ }^{21}$

\begin{tabular}{llll} 
Class & Order & Family & Genus \\
\hline \hline Demospongiae & & & \\
& Dictyoceratida & \\
\cline { 2 - 3 } & & Dysideidae \\
& Irciniidae & \\
& Spongiidae & \\
& Thorectidae & \\
\cline { 2 - 3 } & & Aplysinopsis \\
& & Cacospongia \\
& & Fasciospongia \\
& & Fascaplysinopsis \\
& & Hytrios \\
& & Luffariella \\
& & Thorectandra \\
\hline \hline
\end{tabular}

\subsection{Isolation}

An undescribed dictyoceratid sponge (PTN3_21C), was collected from an underwater cave at the southwest of 'Eua, Tonga. The sponge was extracted twice in $\mathrm{MeOH}$ and the extracts were cyclic loaded onto reversed-phase PSDVB beads. The resin was batch eluted with increasing amounts of $\mathrm{Me}_{2} \mathrm{CO}$ in $\mathrm{H}_{2} \mathrm{O}$. NMR examination of the screened fractions showed that the interesting signals were confined to the $75 \% \mathrm{Me}_{2} \mathrm{CO} / \mathrm{H}_{2} \mathrm{O}$ fraction. Further chromatographic steps employing reversed-phase HPLC (depicted in Scheme 6.1) led to the isolation of the known thorectolide (48), and a novel sesterterpene, secothorectolide (49). Use of HPLC led to the isolation of two impure compounds with a very similar chromophore. Preliminary NMR analysis of fractions $\mathbf{D}$ and $\mathbf{E}$ (Scheme 6.1) showed similarites to each other, however the aldehyde proton that appears in the ${ }^{1} \mathrm{H}$ NMR spectrum of fraction $\mathbf{D}$ was absent in fraction E. Mass spectroscopy indicated a molecular formula of $\mathrm{C}_{25} \mathrm{H}_{36} \mathrm{O}_{5}$ for fraction $\mathbf{E}$, and a literature search of the sesterterpene class and comparison of the NMR data revealed the compound to be thorectolide (48). Compound 48 was reported from a New Caledonian sponge Hyrtios sp. in $1996{ }^{120}$

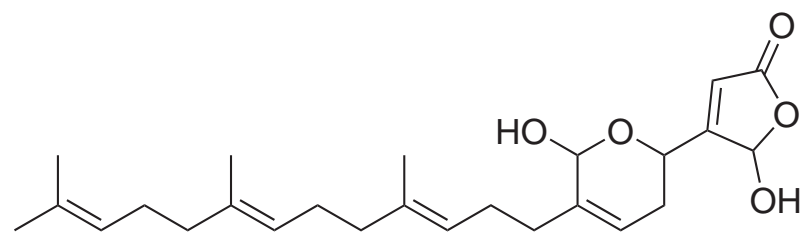

48 


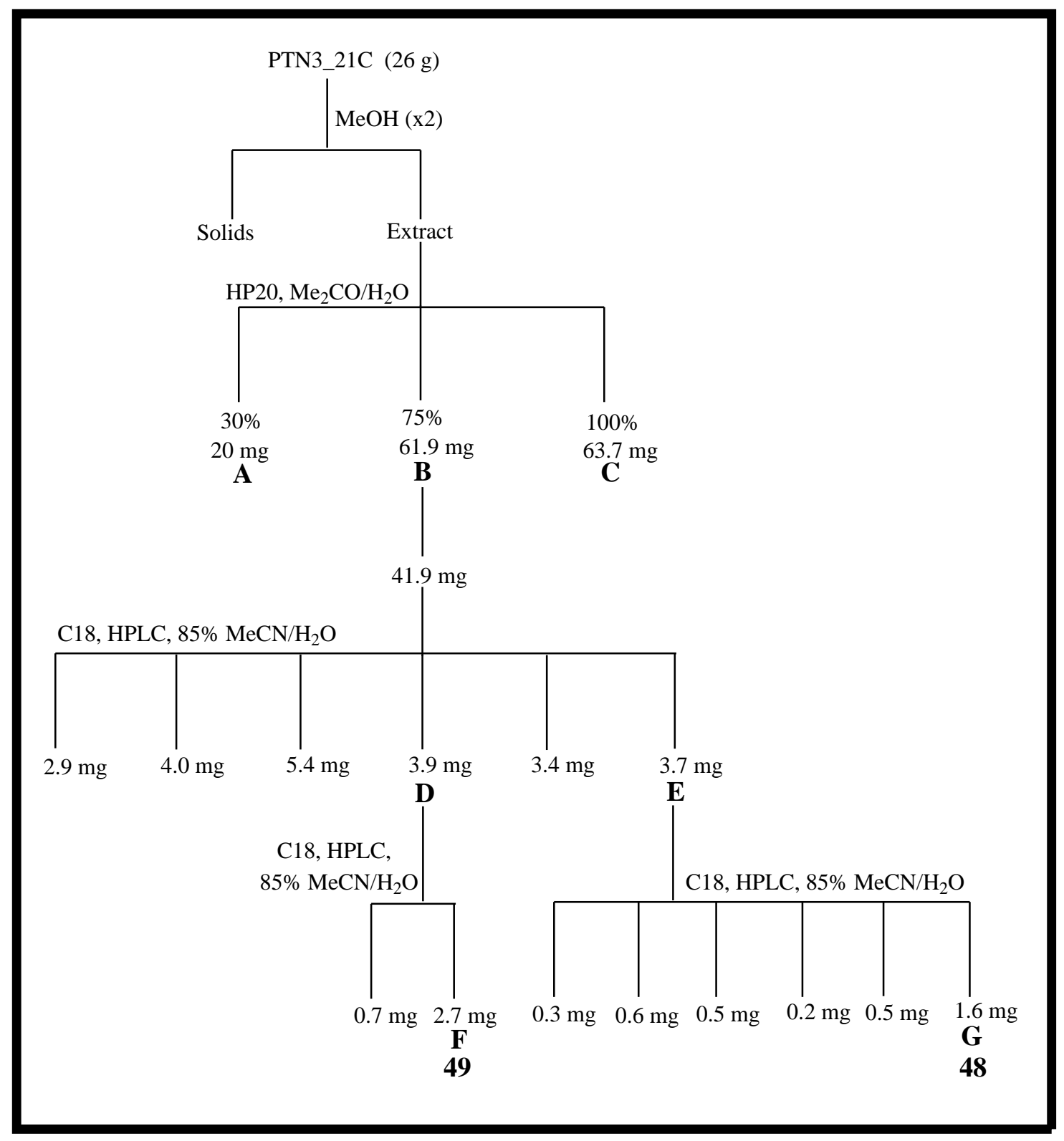

Scheme 6.1. Isolation of thorecetolide (48) and secothorectolide (49) from PTN3_21C, collected from 'Eua, Tongatapu. 


\subsection{Secothorectolide}

The observation of a pseudomolecular ion by positive-ion mode HRESIMS indicated a molecular formula of $\mathrm{C}_{25} \mathrm{H}_{36} \mathrm{O}_{5}$ for compound (49) $\left(\mathrm{m} / z\right.$ 439.2460, $[\mathrm{M}+\mathrm{Na}]^{+}, \Delta 0.0$ ppm), which requires eight double bond equivalents. Examination of the ${ }^{13} \mathrm{C} \mathrm{NMR}$ spectrum revealed only 24 resonances, however the carbon signal observed at $170.3 \mathrm{ppm}$ accounted for two different carbons, thereby accounting for all 25 carbons suggested by the molecular formula. The ${ }^{1} \mathrm{H}$ NMR spectrum accounted for 34 protons, suggesting two exchangeable protons. Analysis of the HSQC spectrum confirmed the attachment of these 34 protons to carbon.

Initial analysis of the ${ }^{13} \mathrm{C}$ and multiplicity-edited HSQC spectra revealed 19 protonated carbons; four methyls $\left(\delta_{\mathrm{C}} 16.16 ; 16.20 ; 17.9,25.9\right)$, seven methylenes $\left(\delta_{\mathrm{C}} 24.7 ; 26.7\right.$; $26.88 ; 26.89 ; 34.8 ; 39.8 ; 39.9)$, six olefinic methines $\left(\delta_{\mathrm{C}} 118.9 ; 123.0 ; 124.1 ; 124.5\right.$, $147.7 ; 194.9)$, two oxymethines $\left(\delta_{\mathrm{C}} 67.0 ; 97.8\right)$, leaving six non-protonated carbons $\left(\delta_{\mathrm{C}} 131.6 ; 135.4 ; 136.8 ; 146.1 ; 170.3,170.3\right)$. The quaternary carbon resonance at $\delta_{\mathrm{C}} 170.3$ is characteristic of an $\alpha, \beta$-unsaturated lactone or acid. A highly deshielded carbonyl methine $\left(\delta_{\mathrm{H}} 9.41, \delta_{\mathrm{C}}\right.$ 194.9) indicated the presence of an $\alpha, \beta$-unsaturated aldehyde. Four quaternary carbon resonances $\left(\delta_{\mathrm{C}} 131.6,135.4,136.8,146.1\right)$, together with olefinic methines at $\delta_{\mathrm{H}} 123.0,124.1,124.5,147.7$, are typical for four trisubstituted olefins. With five double bonds accounted for, this requires that the molecule be monocyclic.

HMBC correlations observed from two of the methyl singlets $\mathrm{CH}_{3}-20\left(\delta_{\mathrm{H}} 1.68 ; \delta_{\mathrm{C}} 25.9\right)$ and $\mathrm{CH}_{3}-21\left(\delta_{\mathrm{H}} 1.60 ; \delta_{\mathrm{C}} 17.9\right)$ to the same two carbons; olefinic methine carbon $\mathrm{CH}-18\left(\delta_{\mathrm{H}} \quad 5.08 ; \delta_{\mathrm{C}} 124.5\right)$ and quaternary olefinic carbon $\mathrm{C}-19\left(\delta_{\mathrm{C}} 131.6\right)$ as well as to each other implied the presence of geminal methyls as part of a trisubstituted double bond. Long-range COSY correlations from $\mathrm{H}-18$ to $\mathrm{H}_{3}-20$, in conjunction with HMBC correlations from $\mathrm{H}-18$ to $\mathrm{CH}_{3}-20$ and $\mathrm{CH}_{3}-21$, confirmed this connectivity. HMBC correlations from $\mathrm{H}-18$ to methylene carbon $\mathrm{CH}_{2}-17\left(\delta_{\mathrm{H}} 2.05 ; \delta_{\mathrm{C}} 26.9\right)$ and a COSY correlation between $\mathrm{H}_{2}-18$ and $\mathrm{H}_{2}-17$ extended the fragment further, unveiling substructure A (Figure 6.2) as an isoprene unit. 


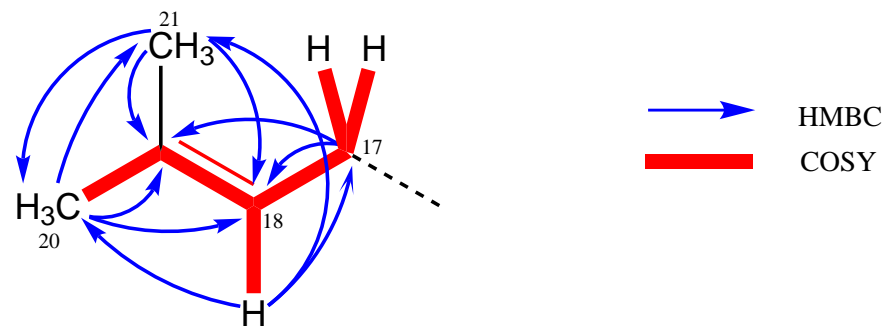

Figure 6.2. COSY and HMBC correlations establishing connectivity of the terminal isoprene unit, substructure A, of secothorectolide (49).

COSY and HMBC correlations between $\mathrm{CH}_{2}-17$ and methylene $\mathrm{CH}_{2}-16\left(\delta_{\mathrm{H}} 1.96\right.$; $\delta_{\mathrm{C}}$ 39.9), established the connectivity between the two respective carbons. Further HMBC correlations were observed from $\mathrm{H}_{2}-16$ to an olefinic quaternary carbon $\mathrm{C}-15$ $\left(\delta_{\mathrm{C}}\right.$ 135.4), olefinic methine carbon $\mathrm{CH}-14\left(\delta_{\mathrm{H}} 5.08 ; \delta_{\mathrm{C}} 124.1\right)$ and methyl carbon $\mathrm{CH}_{3}$ $22\left(\delta_{\mathrm{H}} 1.59 ; \delta_{\mathrm{C}} 16.2\right)$, suggesting the presence of another trisubstituted double bond. HMBC correlations from $\mathrm{H}_{3}-22$ to $\mathrm{C}-16, \mathrm{C}-15$ and $\mathrm{C}-14\left(\delta_{\mathrm{H}} 5.08 ; \delta_{\mathrm{C}} 124.1\right)$, together with COSY correlations between $\mathrm{H}_{3}-22$ and $\mathrm{H}-14$ confirmed this connection.

Two further methylenes $\mathrm{CH}_{2}-13\left(\delta_{\mathrm{H}} 2.05 ; \delta_{\mathrm{C}} \quad 26.9\right)$ and $\mathrm{CH}_{2}-12\left(\begin{array}{lll}\delta_{\mathrm{C}} & 39.8, \delta_{\mathrm{H}} & 1.96\end{array}\right)$ were placed next to the double bond based on COSY and HMBC correlations observed between $\mathrm{CH}-14, \mathrm{CH}_{2}-13$ and $\mathrm{H}_{2}-12 . \mathrm{CH}_{2}-12$ showed further $\mathrm{HMBC}$ correlations to ${ }^{13} \mathrm{C}$ resonances attributed to another trisubstituted double bond- C-11 ( $\left.\delta_{\mathrm{C}} 136.8\right)$, olefinic methine $\mathrm{CH}-10\left(\delta_{\mathrm{H}} 5.10 ; \delta_{\mathrm{C}} 123.0\right)$ and an attached methyl, $\mathrm{CH}_{3}-23\left(\delta_{\mathrm{H}} 1.57 ; \delta_{\mathrm{C}} 16.2\right)$. COSY and HMBC correlations from $\mathrm{H}-10$ and $\mathrm{H}_{2}-9\left(\delta_{\mathrm{H}} \quad 2.05 ; \delta_{\mathrm{C}} 26.9\right)$ extended the fragment further, unveiling substructure B (Figure 6.3) as two unfunctionalised isoprene units.

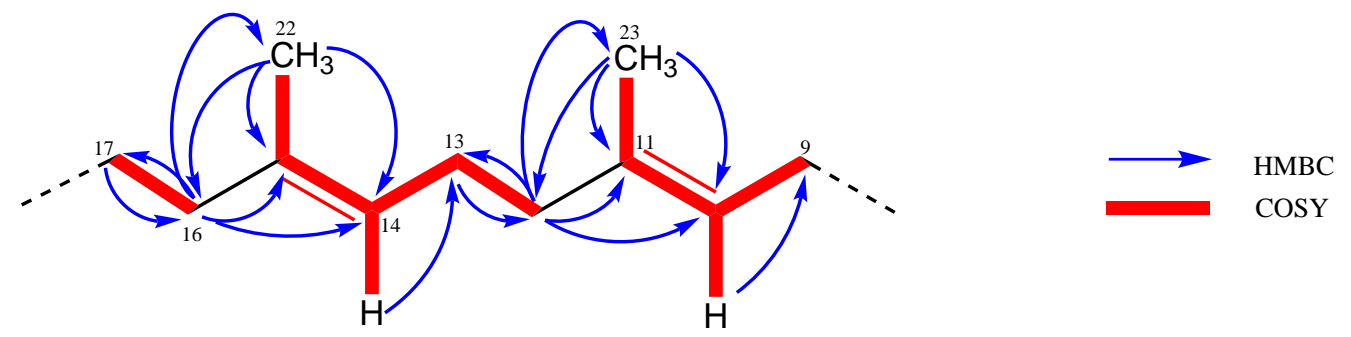

Figure 6.3. COSY and HMBC correlations establishing connectivity of the isoprene units, substructure B, of secothorectolide (49).

COSY correlations were observed from $\mathrm{H}_{2}-9$ to methylene proton $\mathrm{H}_{2}-8\left(\delta_{\mathrm{H}} 2.30 ; \delta_{\mathrm{C}} 24.7\right)$ that established two contiguous methylenes, confirmed through HMBC correlations from 
$\mathrm{H}_{2}-9$ to $\mathrm{C}-8$ and $\mathrm{H}_{2}-8$ to $\mathrm{C}-9$. Further HMBC correlations from $\mathrm{H}_{2}-8$ to an olefinic quaternary carbon $\mathrm{C}-7\left(\delta_{\mathrm{C}} \quad 146.1\right)$ and olefinic methine carbon $\mathrm{CH}-6\left(\delta_{\mathrm{H}} 6.55 ; \delta_{\mathrm{C}} \quad 147.7\right)$ revealed another trisubstituted double dond. CH-6 has an unusual, highly deshielded chemical shifts compared to the two previous trisubstituted double bonds. The H-6 proton appeared at $\delta_{\mathrm{H}} 6.55 \mathrm{ppm}$ while its carbon C-6 resonated at $\delta_{\mathrm{C}} 147.7 \mathrm{ppm}$ and the C7 carbon resonance appeared at $\delta_{\mathrm{C}}$ 146.1. With all four methyls accounted for, this trisubstituted double bond was considered to have a different chemical environment. The $\mathrm{H}_{2}-8$ proton showed an extra HMBC correlation to the aldehyde carbon C-24 $\left(\delta_{\mathrm{H}} 9.41\right.$; $\delta_{\mathrm{C}}$ 194.9). The aldehyde proton $\mathrm{H}-24$ showed HMBC correlations to three carbons, C7, C-6, and C-8, establishing its connection to the polarised trisubstituted double bond. Further analysis of the COSY spectrum revealed a long-range correlation between H-6 and $\mathrm{H}_{2}-8$, together with HMBC correlations from $\mathrm{H}-6$ to C-24 and C-7, and confirmed the connectivity of the trisubstituted double bond (Figure 6.5). The deshielding effect on aldehyde carbon C-24 was consistent with the presence of a conjugated double bond (C-6 and C-7). In addition, the stereochemistry of the double bond $\Delta_{6,7}$ was assigned as $E$, based on the chemical shift of the aldehyde proton, $\delta_{\mathrm{H}} 9.41 \mathrm{ppm}$, corresponding to the slightly shielded values recognised for the $E$ configuration ( $E$ : 9.3-9.4 ppm; $Z$ : 10.0-10.1 ppm) of this functional group. ${ }^{118,131,153}$

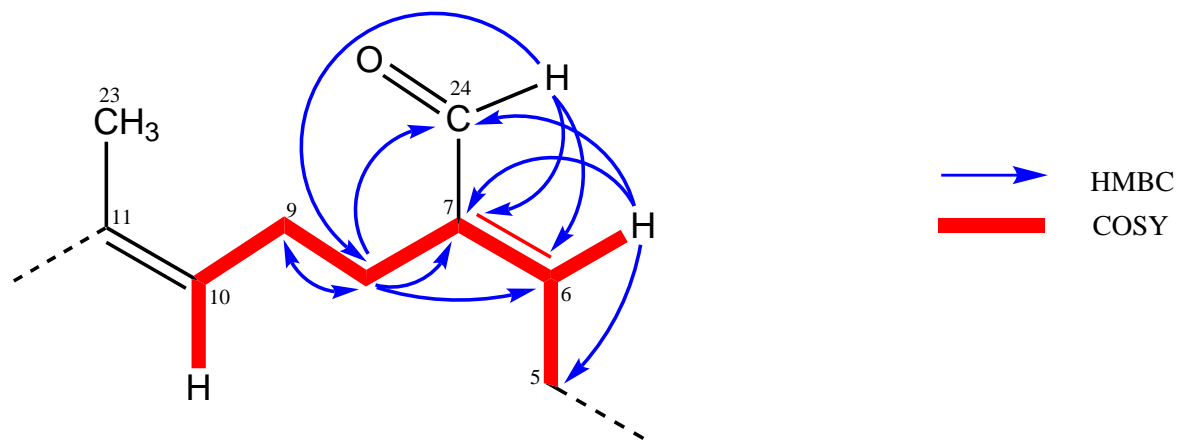

Figure 6.4. COSY and HMBC correlations establishing connectivity of the isopropene unit, substructure C, of secothorectolide (49).

Further analysis of the HMBC spectrum showed extra correlations from H-6 to methylene $\mathrm{CH}_{2}-5\left(\delta_{\mathrm{H}} \quad 2.81,2.86 ; \delta_{\mathrm{C}} \quad 34.8\right)$ and oxymethine carbon $\mathrm{CH}-4\left(\begin{array}{lll}\delta_{\mathrm{H}} & 4.82 ; \delta_{\mathrm{C}} & 67.0\end{array}\right)$, assigning a methylene carbon $\mathrm{CH}_{2}-5$ between the polarised double bond (C-6 and C-7), and the oxymethine $\mathrm{CH}-4$. The difference in chemical shift of the two protons of this methylene $\mathrm{CH}_{2}-5$ is consistent with an adjacent chiral centre (CH-4). HMBC correlations 
from the $\mathrm{H}_{2}-5$ protons to $\mathrm{C}-7, \mathrm{C}-6$ and $\mathrm{C}-4$ are consistent with this assignment. In the coupled HSQC spectrum, the oxymethine CH-4 has ${ }^{1} J_{\mathrm{CH}}$ of $147 \mathrm{~Hz}$ which is typical for that of a $s p^{3}$ carbon attached to oxygen. COSY correlations were observed from $\mathrm{H}_{2}-5$ to H-4 and H-6 that confirmed this skeletal arrangement. This connectivity was further supported by the triplet signal observed in the ${ }^{1} \mathrm{H}$ NMR spectrum for olefinic methine proton $\mathrm{H}-6$ which indicated a methylene proton $\mathrm{CH}_{2}-5$ adjacent.

With 21 of the 25 carbons and 33 of the 36 protons accounted for, a fragment containing four carbons, three oxygens, three hydrogens including an exchangeable proton, remained to be assigned $\left(\mathrm{C}_{4} \mathrm{H}_{3} \mathrm{O}_{3}\right)$. The chemical shift of the $\mathrm{C}-1\left(\delta_{\mathrm{C}}\right.$ 170.3) carbonyl was typical of an $\alpha, \beta$-unsaturated lactone. Also supporting this assumption was the fact that five of the double bond eqiuvalents were accounted for, leaving three double bond equivalents. These requirements are consistent with that of a butenolide ring system. The oxymethine proton $\mathrm{H}-4$ showed weak HMBC correlations to three carbons, C-6, C-2 $\left(\delta_{\mathrm{H}} \quad 6.11 ; \delta_{\mathrm{C}} 118.9\right.$ ), and C-5. The olefinic methine proton $\mathrm{H}-2$ also showed HMBC correlations to $\mathrm{C}-1\left(\delta_{\mathrm{C}} 170.3\right), \mathrm{C}-25\left(\delta_{\mathrm{H}} \quad 6.18 ; \delta_{\mathrm{C}}\right.$ 97.8), and C-4. Weak COSY correlations between $\mathrm{H}-2$ and $\mathrm{H}-4$ but not between $\mathrm{H}-25$ and $\mathrm{H}_{2}-4$ (in the case of $\mathbf{4 6}$ and 47) was observed, which suggested a $\beta$-substituted- $\gamma$-hydroxybutenolide. With aid from the literature, the ring system was assigned as a $\beta$-substituted- $\gamma$-hydroxybutenolide ring, which is also encountered in luffariellolide, ${ }^{108}$ luffariolides, ${ }^{10,130}$ manoalide, ${ }^{117,119}$ luffariellins, ${ }^{118,131}$ cacospongiolides, ${ }^{122,123}$ fasciospongides, ${ }^{126}$ and sarcotins. ${ }^{154}$ In addition, the $E$-configuration of the C-6-C-7 prevents ring closure between the C-24 aldehyde and the hydroxyl group at C-4 which lead to the formation of thorectolide (48). Therefore the structure of secothorectolide is given as $\mathbf{4 9}$ with NMR data presented in Table 6.2.

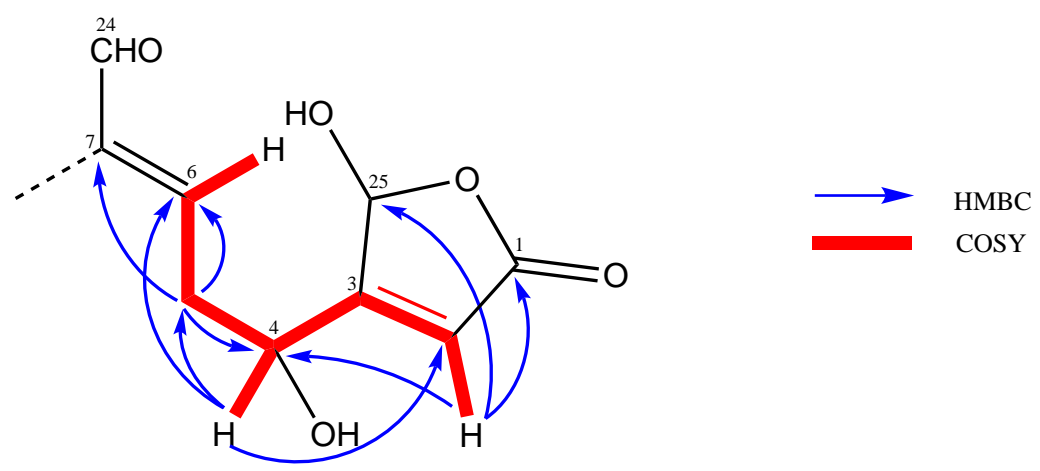

Figure 6.5. COSY and HMBC correlations establishing connectivity of the isopropene unit, substructure D, of secothorectolide (49). 


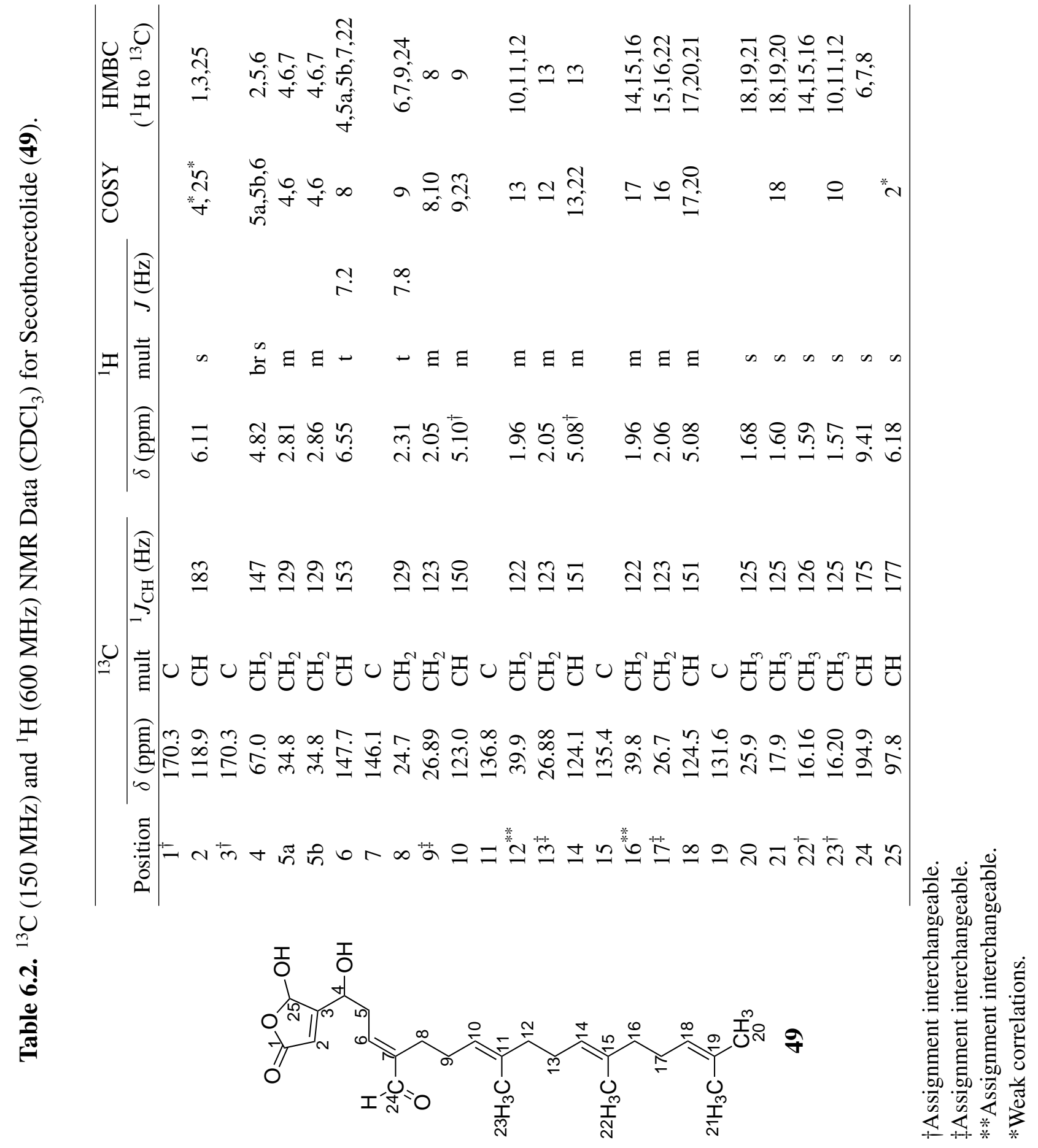




\subsection{Biological Activity}

The biological activity profile of thorectolide (48) and secothorectolide (49) against human cancer cell lines has undergone preliminary investigation. An MTT assay on ovarian cancer (1A9) cells was performed at the School of Biological Sciences, VUW. Compounds 48 and 49 were found to be moderately cytotoxic with $\mathrm{IC}_{50}$ values of 3.74 and $2.45 \mu \mathrm{M}$ respectively. ${ }^{86}$

\subsection{Related Compounds}

Two isomeric linear sesterterpenes (152 and 153) were isolated from the Caribbean sponge Thorecta horridus. ${ }^{155}$ Compound $\mathbf{1 5 2}$ shown a marked inflammatory activity, inducing the release of histamine and causing oedema in the paw of test animals. Luffarins A-Z have been reported from the Australian marine sponge Luffariella geometrica and they are classified into 14 bicyclic sesterterpenes based on their chemical structures; ${ }^{118}$ luffarins A-N; one bicyclic bisnorsesterterpene, luffarin O; one monocyclic sesterterpene, luffarin P; and six acyclic sesterterpenes, luffarins Q-V (152-158), in addition to four diterpenoidal derivatives, luffarin W-Z. Luffarin Q and compound 152, have similar structures and both compounds were reported to have $E$ geometry for the three double bonds. For this reason, it was suggested that $\mathbf{1 5 2}$ and luffarin Q are the same compound. Luffarin $\mathrm{T}$ (156) is a dehydro analogue of luffarin $\mathrm{S}$ (155) while luffarin $\mathrm{V}$ (158) is a dihdro analogue of both luffarins $\mathrm{T}$ and $\mathrm{U}$ (156 and 157). Cacospongionolide $\mathrm{D}$ (159) and (6Z)-luffarin V (160) were isolated from the marine sponge Fasciospongia cavernosa from the Bay of Naples. ${ }^{155}$ Despite the structural relationship with luffarins, cacospongionolide D (159) exhibited significant cytotoxicity. ${ }^{156}$ This notion suggested a possible relation between the presence of the $\alpha$-hydroxybutenolide moiety and the cytotoxicity.

A new sesterterpene (161), related to luffarins, has been isolated from the sponge Fasciospongia cavernosa from the Adriatic Sea. ${ }^{129}$ The absolute stereochemistry of $\mathbf{1 6 1}$ was determined by application of Mosher's method. Fasciospongides B and C (162 and 
163) were obtained from the New Caledonian sponge Fasciospongia sp. ${ }^{126}$ Compounds 162 and 163 possess a new oxidized variant of the cyclohexenyl ring found in manoalide (109) and other analogues. Thorectolide monoacetate (164) was first obtained from the marine sponge Thorectandra excavatus. ${ }^{124}$ The absolute configuration of C-24 and C-4 were assigned following re-isolation of $\mathbf{1 6 4}$ from a New Caledonian marine sponge of the genus Hyrtios, together with thorectolide (48). ${ }^{120}$ The hydroxyl group at C-24 was established as axial and the absolute configuration of C-4 was assigned as $R$ by measuring the Cotton Effect of the diol, obtained by reduction of $\mathbf{1 6 4}$.

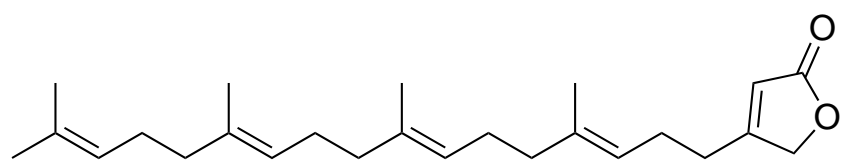

152

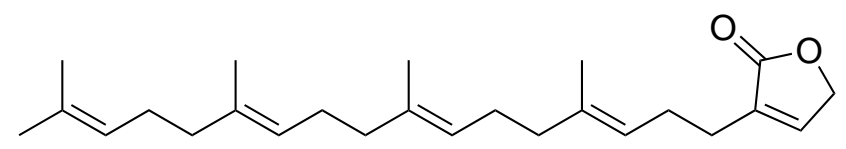

153

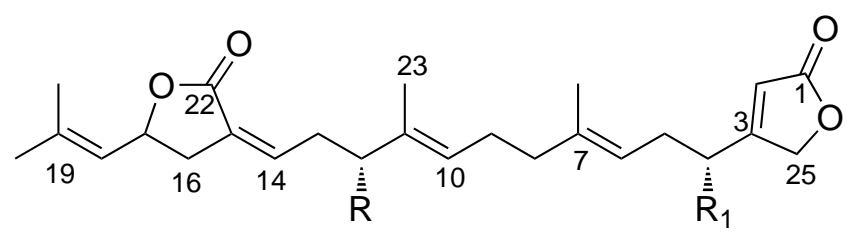

$154(6 E, 10 E, 14 Z) \quad \mathrm{R}=\mathrm{H} \quad \mathrm{R}_{1}=\mathrm{OH}$

$155(6 E, 10 E, 14 Z) \quad \mathrm{R}=\mathrm{H} \quad \mathrm{R}_{1}=\mathrm{OAc}$

$158(6 E, 10 E, 14 E) \quad \mathrm{R}=\mathrm{H} \quad \mathrm{R}_{1}=\mathrm{H}$

$160(6 Z, 10 E, 14 E) \quad \mathrm{R}=\mathrm{H} \quad \mathrm{R}_{1}=\mathrm{H}$

$161(6 Z, 10 E, 14 E) \quad \mathrm{R}=\mathrm{OAc} \quad \mathrm{R}_{1}=\mathrm{H}$
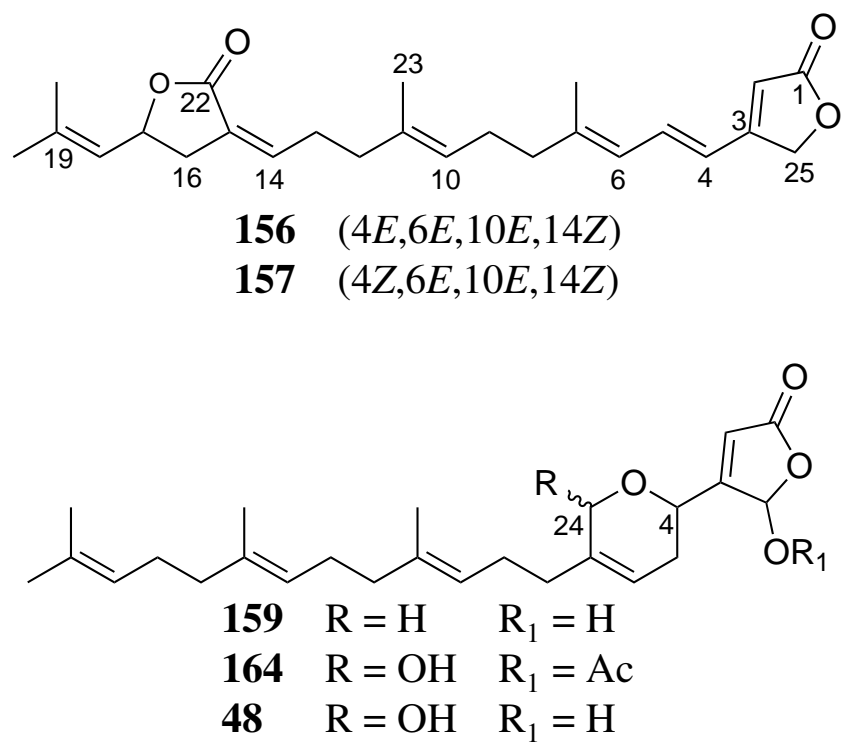
<smiles>CC(=O)CCCC(C)(C)C(=O)CC/C(C)=C/CCC1=CCC(C2=CC(=O)OC2O)OC1O</smiles>

162<smiles>CC(=O)CCCC(C)(C)C(=O)CC/C(C)=C/CC/C(C=O)=C\CC(O)C1=CC(=O)OC1O</smiles>

163

\subsubsection{Biosynthetic relationship between all Luffarella metabolites}

Biosynthetically, a relationship could be recognized between the various luffarins as illustrated in Scheme 6.2. Luffarins appear to belong to the same enantiomeric series as reported for manoalide-type marine natural products. It is also curious to note that none of the acyclic luffarins incorporated the hydroxylated butenolide functionality. Perhaps the most interesting luffarins from a biosynthetic point of view are luffarins B (165) and $\mathrm{O}$ (166), which were the first examples of a hitherto unknown cyclization pattern in compounds of this class. ${ }^{118}$ The E-configuration of the C-6-C-7 in secothorectolide (49) prevents ring closure between the C-24 aldehyde and the hydroxyl group at C-4 that lead to the formation of thorectolide (48), as illustrated in pathway $\mathrm{C}$ (Scheme 6.2).<smiles>CC1=C(CC/C2=C/CC(O)C3=CC(=O)OC3OC2O)[C@]2(C)CCCC(C)(C)C2CC1</smiles>

165<smiles>CC1=C(CCC2=CC=CC(O)=COC2)[C@@]2(C)CCCC(C)(C)C2CC1</smiles>

166 


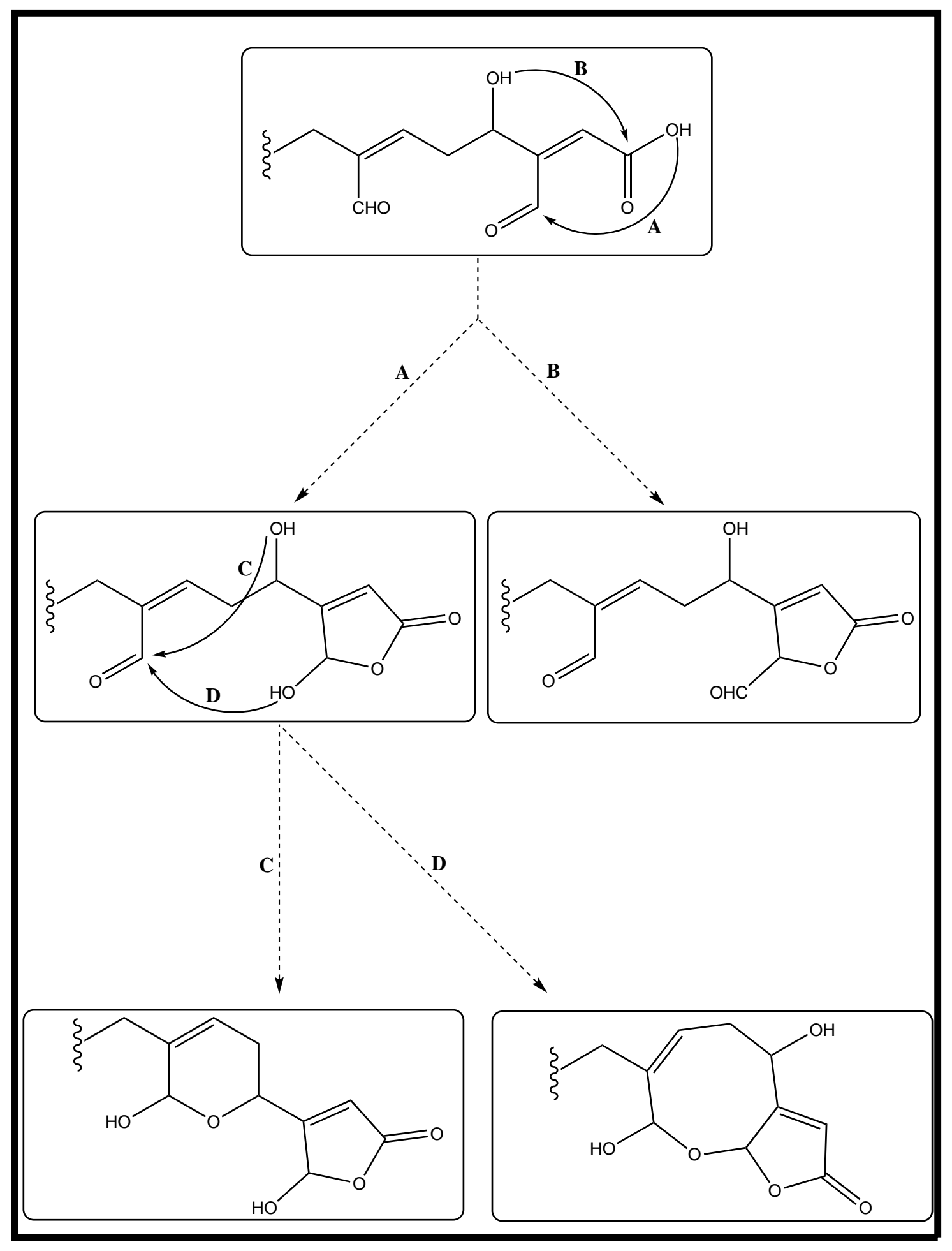

Scheme 6.2. Postulated biosynthetic relationship between all known Luffariella metabolites. ${ }^{118}$ 


\section{Chapter 7}

\section{Conclusion}

Marine biomedicine is one of the most recent focal points in assessing the role of the oceans in human health. There is simply no question that the vast diversity of plants and animals in the sea will contribute toward the amelioration of human suffering.

Marine sponges do not have physical means of defense and so have developed a rich chemical arsenal that can be exploited in the search for new pharmaceutical leads. Not suprisingly, marine sponges are still the most prolific producers of biologically active marine natural products.

Over the course of this study, various species of Tongan marine sponge were examined using an NMR-based screening method, in order to identify which sponge extracts were worthy of further investigation. The isolation of metabolites from selected sponges was then guided by NMR analysis, which led to isolation of three new chemical structures from two different species, together with 11 known compounds.

The two novel sesterterpenes, isoluffariellolide (46) and 1-O-methylisoluffariellolide (47) share the same backbone pattern as the known luffariellolide (45) and 25-Omethylluffariellolide (107) respectively, and differ only in the substitution on the butenolide ring. In the literature, the majority of the secondary metabolites that have the butenolide ring are $\beta$-substituted with only few $\alpha$-substituted (in the case of $\mathbf{4 6}$ and 47). Isoluffariellolide (46) was found to be approximately six times less cytotoxic than 1-Omethylisoluffariellolide (47). Interestingly, these results suggested that the 1-O-methyl group in compound $\mathbf{4 7}$ plays an important role in the cytotoxicity of the compound.

Secothorectolide (49) is a ring-opened and geometric isomer of the known compound thorectolide (48). This ring closure and opening relationship was also observed between manoalide (109) and secomanoalide (110), as well as luffariellins A (141) and B (142). Despite the different carbon skeleton, the functional groups in 141 and 142 are similar with those in $\mathbf{1 0 9}$ and 110, respectively, and not surprisingly the biological properties are 
almost identical. The biological activities of compounds $\mathbf{4 8}$ and $\mathbf{4 9}$ were almost the same, which would give an insight into the structure-activity relationship (SAR) between these types of compounds.

In addition, the structurally related known bromotyrosines (52-54) and pyrroloquinoline metabolites $(\mathbf{5 5 - 5 6 )}$ isolated in this research can be tested in screening libraries, that are unbiased by specific biological activity (as in bioassay guided studies), in order to understand their SAR and mode of action.

In New Zealand sponges, primary metabolites dominate the $75 \% \mathrm{Me}_{2} \mathrm{CO} / \mathrm{H}_{2} \mathrm{O}$ fraction (the mass window). Even though most primary metabolites were discarded in both the $30 \% \mathrm{Me}_{2} \mathrm{CO} / \mathrm{H}_{2} \mathrm{O}$ and $100 \% \mathrm{Me}_{2} \mathrm{CO}$ fractions, the levels of secondary metabolites were very low. The screening technique was adapted to find the approximately one in ten sponges that contained enough secondary metabolites to detect. Using this general methodology on tropical sponges we found that the $75 \% \mathrm{Me}_{2} \mathrm{CO} / \mathrm{H}_{2} \mathrm{O}$ was predominantly secondary metabolites in every sponge examined. The problem was not finding secondary metabolites, but finding novel compounds. While some of the techniques developed in this study have helped find novel compounds, more sophisticated methods will have to be developed to rapidly identify well known secondary metabolites and detect the presence of novel compounds.

Furthermore, sponges that are abundant in Tongan waters have been investigated before by other marine natural groups (collected from Fiji, Vanuatu, Papua New Guinea, Solomon Islands, etc.). Not surprisingly, their chemical content is quite similar to that from Tongan sponges. From our experience from these collecting trips, the less abundant sponges (which might be ignored by other research groups) tend to have higher probablility of containing novel secondary metabolites. Therefore, on future collecting trips, these sponges can be targeted, and with the Tongan sponges proved to have higher secondary metabolites content compared to New Zealand sponges, isolation of novel compounds from smaller amount of sponges can be achieved using the VUW screening method. 


\section{Chapter 8}

\section{Experimental}

\subsection{General Experimental}

NMR spectra were obtained using a Varian Direct Drive spectrometer equipped with a triple resonance $\mathrm{HCN}$ cryogenic probe, operating at $600 \mathrm{MHz}$ for the ${ }^{1} \mathrm{H}$ nucleus, $150 \mathrm{MHz}$ for the ${ }^{13} \mathrm{C}$ nucleus and $60 \mathrm{MHz}$ for ${ }^{15} \mathrm{~N}$ nucleus. All HSQC spectra were obtained as coupled HSQC. Chemical shifts $\delta(\mathrm{ppm})$ were internally referenced to the residual solvent peak. ${ }^{157}$ For acid sensitive compounds, a catalytic amount(1-2 $\left.\mu \mathrm{L}\right)$ of $d_{5}$-pyridine is added to each NMR sample performed in $\mathrm{CDCl}_{3}$ to prevent compound degradation due to acidity associated with the solvent. ${ }^{1} \mathrm{H}$ NMR quantification of samples was performed with an internal $\mathrm{CH}_{3} \mathrm{NO}_{2}$ standard $\left(100 \mu \mathrm{L}\right.$ in $\left.5 \mathrm{~mL} \mathrm{CDCl}_{3}\right)$, using the acquisition parameters described by West. ${ }^{52}$ High-resolution mass spectra were obtained using a Micromass Q-TOF Premier mass spectrometer. TLC analyses were performed on Machery-Nagel Alugram SIL G/UV ${ }_{254}$ normal-phase silica plates using a mobile phase of $5 \% \mathrm{MeOH} / \mathrm{CH}_{2} \mathrm{Cl}_{2}$ unless otherwise stated. The TLC plates were visualised by either (1) fluorescence quenching under UV light $(\lambda=254 \mathrm{~nm})$, (2) fluorescence under UV light $(\lambda=350 \mathrm{~nm})$, (3) dipping in $5 \% \mathrm{H}_{2} \mathrm{SO}_{4}$ (conc.)/MeOH solution, followed by dipping in a solution of $0.1 \%$ vanillin in $\mathrm{EtOH}(\% \mathrm{wt} / \mathrm{vol})$ then heating, or a combination of the above.

Normal-phase column chromatography was performed using YMC Co. LTD 2,3dihydropropoxypropyl-derivatised silica (DIOL), or silica $\left(\mathrm{SiO}_{2}\right)$. Reversed-phase column chromatography was carried out using Supelco Diaion HP20 or HP20SS poly(styrene divinylbenzene) (PSDVB) resin. All solvents used in bench-top chromatography were glass-distilled. All other reagents were purchased commercially (at least reagent grade) and distilled prior to use when necessary. High-pressure liquid chromatography (HPLC) was performed using a Rainin Dynamax SD-200 solvent delivery module with $25 \mathrm{~mL}$ pump heads (analytical scale), or a Varian PrepStar 210 solvent delivery module with 100 $\mathrm{mL}$ pump heads (preparative and semi-preparative scale). UV detection for HPLC runs 
was obtained with a Varian Prostar 335 photodiode array detector. All organic solvents used were HPLC grade and $\mathrm{H}_{2} \mathrm{O}$ was glass-distilled and deionised using a MilliQ system. Solvent mixtures are reported as \% vol/vol, unless otherwise stated.

\subsection{Investigation of Genus Fascaplysinopsis}

\subsubsection{Initial Fractionation of Fascaplysinopsis sp.}

The sponge (PTN3_19A and PTN3_22B) was collected by hand using SCUBA from an underwater cave at the southwest of Eua, Tonga in late November 2008. The sample was frozen immediately and kept at $-18^{\circ} \mathrm{C}$ until extraction. Voucher samples (PTN3_19A and PTN3_22B) have been deposited and stored in 100\% EtOH, at the School of Chemical and Physical Sciences, Victoria University of Wellington, New Zealand.

The sponge (200 $\mathrm{g}$ frozen weight) was cut into small pieces and extracted with $\mathrm{MeOH}(2$ $\times 1 \mathrm{~L}$ each) for 24 hours. The second then first methanolic extracts were cylic loaded* onto a glass column packed with HP20 beads $(200 \mathrm{~mL})$ pre-equilibrated in MeOH. The combined eluent was then diluted with $\mathrm{H}_{2} \mathrm{O}(2 \mathrm{~L})$ and passed through the same column. This eluent was further diluted with $\mathrm{H}_{2} \mathrm{O}(4 \mathrm{~L})$ and passed again through the same column. The loaded column was then washed with $600 \mathrm{~mL}$ of $\mathrm{H}_{2} \mathrm{O}$ and fractionated with $600 \mathrm{~mL}$ of increasing concentrations of $\mathrm{Me}_{2} \mathrm{CO}$ in $\mathrm{H}_{2} \mathrm{O}$; (i) $30 \%$ (fraction A), (ii) $40 \%$ (fraction B), (iii) $60 \%$ (fraction C), (iv) $80 \%$ (fraction D), (v) $100 \% \mathrm{Me}_{2} \mathrm{CO}$ (fraction E). Fractions A to $\mathbf{D}$ were each individually back-loaded onto glass columns packed with HP20 beads ( $80 \mathrm{~mL}$ ) pre-equilibrated in $\mathrm{MeOH}$. The columns were then washed with $\mathrm{H}_{2} \mathrm{O}(240 \mathrm{~mL})$ and eluted with $\mathrm{Me}_{2} \mathrm{CO}(240 \mathrm{~mL})$. The eluents were then concentrated to dryness to give $149.1 \mathrm{mg}$ of fraction $\mathbf{A}, 92.9 \mathrm{mg}$ of fraction $\mathbf{B}, 379.8 \mathrm{mg}$ of fraction $\mathbf{C}$ and $648.9 \mathrm{mg}$ of fraction D. Fraction E was also concentrated to dryness (614.7 mg).

\footnotetext{
${ }^{*}$ For a detailed discussion of cyclic loading and back loading, please see Chapter 2, Section 2.1.1.
} 


\subsubsection{Isolation of Homofascaplysin A}

Fraction A ( 96.1 mg) was dissolved in $2 \mathrm{~mL}$ HPLC grade MeOH. The sample was then injected onto a semi-preparative $(250 \mathrm{~mm} \times 10 \mathrm{~mm})$ C18 HPLC column pre-equilibrated with $50 \% \mathrm{MeCN} / 0.5 \mathrm{M} \mathrm{HCOOH}_{(a q)}$, with a flow rate of $5 \mathrm{~mL} / \mathrm{min}$ and $\mathrm{UV}$ detection set to $\lambda_{245 \mathrm{~nm}}$ and $\lambda_{280 \mathrm{~nm}}$. The column was then eluted with $50 \% \mathrm{MeOH} / 0.1 \mathrm{M} \mathrm{HCOOH}_{(a q)}$. The fractions eluted between 1.5-2.0 minutes (fraction F), 2.2-3.3 minutes (fraction $\mathbf{G}$ ) were collected. Fraction $\mathbf{F}$ was back-loaded onto a $3 \mathrm{~mL}$ HP20SS column. The column was eluted with $15 \mathrm{~mL}$ of $\mathrm{Me}_{2} \mathrm{CO}$ and then concentrated to dryness. ${ }^{1} \mathrm{H} \mathrm{NMR}$ analysis showed that fraction F contained $13.7 \mathrm{mg}$ homofascaplysin A. Fraction G was backloaded onto a $3 \mathrm{~mL}$ HP20SS column. The column was eluted with $15 \mathrm{~mL}$ of $\mathrm{Me}_{2} \mathrm{CO}$ and then concentrated to dryness. ${ }^{1} \mathrm{H}$ NMR analysis showed that fraction $\mathbf{G}$ contained $10.8 \mathrm{mg}$ of homofascaplysin A. Fraction $\mathbf{F}$ and $\mathbf{G}$ were combined to yield $24.5 \mathrm{mg}$ of homofascaplysin A (43).

\section{Homofascaplysin A (43)}

Amphorphous yellow solid; all spectroscopic data as previously published. ${ }^{91}$

\subsubsection{Isolation of Luffariellolide, Isoluffariellolide, 1- $O$-Methylisoluffa- riellolide}

Fraction $\mathbf{D}(\sim 336 \mathrm{mg})$ was dissolved in a minimum amount of $\mathrm{CH}_{2} \mathrm{Cl}_{2}$ and loaded onto a glass column packed with silica gel $(60 \mathrm{~mL})$ pre-equilibrated in $\mathrm{CH}_{2} \mathrm{Cl}_{2}$. The loaded column was then eluted with $100 \mathrm{~mL}$ portions of: (i) $100 \% \mathrm{CH}_{2} \mathrm{Cl}_{2}$, (ii) $5 \% \mathrm{EtOAc} / \mathrm{CH}_{2} \mathrm{Cl}_{2}$, (iii) $15 \% \mathrm{EtOAc} / \mathrm{CH}_{2} \mathrm{Cl}_{2}$, (iv) $30 \% \mathrm{EtOAc} / \mathrm{CH}_{2} \mathrm{Cl}_{2}$, (v) $50 \%$ EtOAc/ $\mathrm{CH}_{2} \mathrm{Cl}_{2}$, (vi) $100 \%$ EtOAc, all fractions were collected across 129 test-tubes and were concentrated to dryness. The fractions were analysed by TLC and fractions 8-16 were combined to give fraction $\mathbf{H}(9 \mathrm{mg})$ and fractions $37-46$ were combined to give fraction $\mathbf{I}(75.7 \mathrm{mg}) . \quad{ }^{1} \mathrm{H}$ NMR analysis showed that fraction $\mathbf{H}$ contained impure 1-Omethylisoluffariellolide, while fraction I revealed three structurally related compounds. 
Fraction $\mathbf{H}(9 \mathrm{mg})$ was dissolved in a minimum amount of pet. ether and loaded onto a glass column packed with silica gel $(10 \mathrm{~mL})$ pre-equilibrated in pet. ether. The loaded column was then eluted with $30 \mathrm{~mL}$ portions of; (i) $100 \%$ pet. ether, (ii) $5 \% \mathrm{CH}_{2} \mathrm{Cl}_{2} /$ pet. ether, (iii) $10 \% \mathrm{CH}_{2} \mathrm{Cl}_{2}$ /pet. ether, (iv) $15 \% \mathrm{CH}_{2} \mathrm{Cl}_{2}$ /pet. ether, (v) $20 \% \mathrm{CH}_{2} \mathrm{Cl}_{2} /$ pet. ether, (vi) $25 \% \mathrm{CH}_{2} \mathrm{Cl}_{2}$ /pet. ether, (vii) $30 \% \mathrm{CH}_{2} \mathrm{Cl}_{2} /$ pet. ether, (viii) $50 \% \mathrm{CH}_{2} \mathrm{Cl}_{2} /$ pet. ether, (ix) $70 \% \mathrm{CH}_{2} \mathrm{Cl}_{2} /$ pet. ether, (x) $100 \% \mathrm{CH}_{2} \mathrm{Cl}_{2}$, all fractions were collected across 48 test-tubes and were concentrated to dryness. The fractions were analysed by TLC and fractions 33-36 (fraction $\mathbf{J}$ ) were combined. ${ }^{1} \mathrm{H}$ NMR analysis showed that fraction $\mathbf{J}$ contained $0.2 \mathrm{mg}$ of 1-O-methylisoluffariellolide (47).

Fraction I ( $\sim 10 \mathrm{mg})$ was dissolved in $300 \mu \mathrm{L}$ of HPLC grade MeOH. Fifteen $20 \mu \mathrm{L}$ samples were then injected onto an analytical $(250 \mathrm{~mm} \times 4.6 \mathrm{~mm}) \mathrm{C} 18 \mathrm{HPLC}$ column pre-equilibrated with $95 \% \mathrm{MeCN} / \mathrm{H}_{2} \mathrm{O}$, with a flow rate of $1 \mathrm{~mL} / \mathrm{min}$ and $\mathrm{UV}$ detection set to $\lambda_{245 \mathrm{~nm}}$ and $\lambda_{280 \mathrm{~nm}}$. The eluent between 4.7-5.0 minutes (fraction $\mathbf{K}$ ) was collected and then concentrated to dryness. ${ }^{1} \mathrm{H}$ NMR analysis showed that fraction $\mathbf{K}$ contained $1.2 \mathrm{mg}$ of isodehydroluffariellolide (44). The eluent between 8.2-8.8 minutes (fraction L) was collected and concentrated to dryness. ${ }^{1} \mathrm{H}$ NMR analysis showed that fraction $\mathbf{L}$ contained $3.3 \mathrm{mg}$ mixture of isoluffariellolide (46) and accompanied by small amount of luffariellolide (45).

\section{Isodehydroluffariellolide (44)}

Colourless oily residue; all spectroscopic data as previously published. ${ }^{91}$

\section{Luffariellolide (45)}

Yellowish oily residue; all spectroscopic data as previously published. ${ }^{108}$

\section{Isoluffariellolide (46)}

Yellowish oily residue; NMR data see Table 5.3; HRESIMS, observed $\mathrm{m} / z, 409.3471$ $[\mathrm{M}+\mathrm{Na}]^{+}, \mathrm{C}_{25} \mathrm{H}_{38} \mathrm{O}_{3} \mathrm{Na}$ requires 409.2719, $\Delta 0.0752 \mathrm{ppm}$. 


\section{1-O-Methylisoluffariellolide (47)}

Yellowish oily residue; NMR data see Table 5.5; HRESIMS, observed $\mathrm{m} / \mathrm{z} 423.2867$ $[\mathrm{M}+\mathrm{Na}]^{+}, \mathrm{C}_{26} \mathrm{H}_{40} \mathrm{O}_{3} \mathrm{Na}$ requires 423.2875, $\Delta 0.0008$ ppm.

\subsection{Investigation of Dictyoceratid Sponge}

\subsubsection{Isolation of Secothorectolide and Thorectolide}

The sponge (PTN3 21C) was collected by hand using SCUBA from an underwater cave at the southwest of 'Eua, Tonga in late November 2008. The sample was frozen immediately and kept at $-18^{\circ} \mathrm{C}$ until extraction. Voucher sample (PTN3_21C) has been deposited and stored in $100 \%$ EtOH, at the School of Chemical and Physical Sciences, Victoria University of Wellington, New Zealand.

The sponge (26 g frozen weight) was cut into small pieces and extracted with $\mathrm{MeOH}$ $(2 \times 100 \mathrm{~mL}$ each $)$ for 24 hours. The second then first methanolic extracts were cyclic loaded onto a glass coloumn packed with HP20 beads $(25 \mathrm{~mL})$ pre-equilibrated in $\mathrm{MeOH}$. The combined eluent was then diluted with $\mathrm{H}_{2} \mathrm{O}(200 \mathrm{~mL})$ and passed through the same column. This eluent was further diluted with $\mathrm{H}_{2} \mathrm{O}(400 \mathrm{~mL})$ and passed through the column. The column was then washed with $75 \mathrm{~mL}$ of $\mathrm{H}_{2} \mathrm{O}$. The loaded column was eluted with $75 \mathrm{~mL}$ of increasing concentrations of $\mathrm{Me}_{2} \mathrm{CO}$ in $\mathrm{H}_{2} \mathrm{O}$ : (i) $30 \%$ (fraction A), (ii) $75 \%$ (fraction $\mathbf{B}$ ) and (iii) $100 \% \mathrm{Me}_{2} \mathrm{CO}$ (fraction $\mathbf{C}$ ). Fractions $\mathbf{A}$ and $\mathbf{B}$ were each individually back-loaded onto glass columns packed HP20 beads $(75 \mathrm{~mL})$ pre-equilibrated in $\mathrm{MeOH}$. The columns were then washed with $\mathrm{H}_{2} \mathrm{O}(75 \mathrm{~mL})$ and eluted with $\mathrm{Me}_{2} \mathrm{CO}(75 \mathrm{~mL})$. The eluents were then concentrated to dryness to give $20 \mathrm{mg}$ of fraction $\mathbf{A}, 61.9 \mathrm{mg}$ of fraction B. Fraction $\mathbf{C}$ was also concentrated to dryness $(63.7 \mathrm{mg})$.

The TLC and NMR examination of the resulting fractions showed that the interesting signals were confined to the $75 \% \mathrm{Me}_{2} \mathrm{CO} / \mathrm{H}_{2} \mathrm{O}$ fraction. Fraction $\mathbf{B}(\sim 41.9 \mathrm{mg})$ was dissolved in $1.5 \mathrm{~mL}$ of HPLC grade $\mathrm{MeOH}$. Fifteen $100 \mu \mathrm{L}$ samples were then injected 
into a semi-preparative $(250 \mathrm{~mm} \times 10 \mathrm{~mm}) \mathrm{C} 18 \mathrm{HPLC}$ column pre-equilibrated with $85 \% \mathrm{MeCN} / \mathrm{H}_{2} \mathrm{O}$, with a flow rate of $4 \mathrm{~mL} / \mathrm{min}$ and $\mathrm{UV}$ detection set to $\lambda_{245 \mathrm{~nm}}$ and $\lambda_{280 \mathrm{~nm}}$. The eluent between 7.6-8.6 minutes (fraction D) and 11.3-12.3 minutes (fraction E) was collected and then concentrated to dryness. ${ }^{1} \mathrm{H}$ NMR analysis showed that fraction $\mathbf{D}$ contained $3.9 \mathrm{mg}$ of secothorectolide and fraction $\mathbf{E}$ contained $3.7 \mathrm{mg}$ impure thorectolide.

Fraction D (3.9 mg) was dissolved in $140 \mu \mathrm{L}$ of HPLC grade MeOH. Seven $20 \mu \mathrm{L}$ samples were then injected onto an analytical $(250 \mathrm{~mm} \times 4.6 \mathrm{~mm}) \mathrm{C} 18 \mathrm{HPLC}$ column pre-equilibrated with $85 \% \mathrm{MeCN} / \mathrm{H}_{2} \mathrm{O}$, with a flow rate of $1 \mathrm{~mL} / \mathrm{min}$ and $\mathrm{UV}$ detection set to $\lambda_{245 \mathrm{~nm}}$ and $\lambda_{280 \mathrm{~nm}}$. The eluent between 6.6-7.6 minutes (fraction $\mathbf{F}$ ) was collected and then concentrated to dryness. ${ }^{1} \mathrm{H}$ NMR analysis showed that fraction $\mathbf{F}$ contained 2.7 mg of secothorectolide (49).

Fraction E (3.7 mg) was dissolved in $140 \mu \mathrm{L}$ of HPLC grade MeOH. Seven $20 \mu \mathrm{L}$ samples were then injected onto an analytical (250 mm x $4.6 \mathrm{~mm})$ C18 HPLC column pre-equilibrated with $85 \% \mathrm{MeCN} / \mathrm{H}_{2} \mathrm{O}$, with a flow rate of $1 \mathrm{~mL} / \mathrm{min}$ and $\mathrm{UV}$ detection

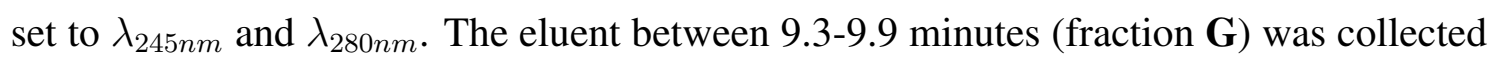
and then concentrated to dryness. ${ }^{1} \mathrm{H}$ NMR analysis showed that fraction $\mathbf{G}$ contained 1.6 $\mathrm{mg}$ of thorectolide (48).

\section{Thorectolide (48)}

Colourless oily residue; all spectroscopic data as previously published. ${ }^{120}$

\section{Secothorectolide (49).}

Colourless oily residue; NMR data see Table 6.2; HRESIMS, observed $m / z 439.2460$ $[\mathrm{M}+\mathrm{Na}]^{+}, \mathrm{C}_{25} \mathrm{H}_{36} \mathrm{O}_{5} \mathrm{Na}$ requires 439.2460, $\Delta 0.0 \mathrm{ppm}$. 


\subsection{Investigation of a Verongiid Sponge}

\subsubsection{Isolation of Aplysamine-2 and Aerophobin-1}

The sponge (PTN3_33F) was collected by snorkel from Ano Beach, Vava'u, Tonga in late November 2009. The sample was frozen immediately and kept at $-18^{\circ} \mathrm{C}$ until extraction. A voucher sample (PTN3_33F) has been deposited and stored in 100\% EtOH, at the School of Chemical and Physical Sciences, Victoria University of Wellington, New Zealand.

The sponge (27 g wet weight) was cut into small pieces and extracted with $\mathrm{MeOH}(2 \mathrm{x}$ $100 \mathrm{~mL}$ each) for 24 hours. The second then first methanolic extracts were loaded onto a glass column packed with HP20 beads (30 mL) pre-equilibrated in $\mathrm{MeOH}$. The combined eluent was then diluted with $\mathrm{H}_{2} \mathrm{O}(200 \mathrm{~mL})$ and passed through the same column. This eluent was further diluted with $\mathrm{H}_{2} \mathrm{O}(400 \mathrm{~mL})$ and passed again through the same column. The loaded column was then washed with $120 \mathrm{~mL}$ of $\mathrm{H}_{2} \mathrm{O}$ and fractionated with $120 \mathrm{~mL}$ of increasing concentrations of $\mathrm{Me}_{2} \mathrm{CO}$ in $\mathrm{H}_{2} \mathrm{O}$ : (i) $30 \%$ (fraction A), (ii) $75 \%$ (fraction B) and (iii) 100\% (fraction C). Fractions A and $\mathbf{B}$ were each individually back loaded onto glass columns packed with HP20 beads $(30 \mathrm{~mL}$ ) pre-equilibrated in $\mathrm{MeOH}$. The columns were then washed with $\mathrm{H}_{2} \mathrm{O}(120 \mathrm{~mL})$ and eluted with $\mathrm{Me}_{2} \mathrm{CO}(120 \mathrm{~mL})$. The eluents were then concentrated to dryness to give $80.6 \mathrm{mg}$ of fraction $\mathbf{A}, 86.7 \mathrm{mg}$ of fraction $\mathbf{B}$. Fraction $\mathbf{C}$ was also concentrated to dryness $(75.8 \mathrm{mg})$.

Fraction $\mathbf{B}(\sim 34.4 \mathrm{mg})$ dissolved in $10 \mathrm{~mL}$ of $\mathrm{MeOH}$ and cyclic loaded onto a glass analytical column packed with $5 \mathrm{~mL}$ HP20SS pre-equilibrated in $\mathrm{MeOH}$. The loaded column was eluted with $30 \mathrm{~mL}$ of increasing concentrations of $\mathrm{Me}_{2} \mathrm{CO}$ in $\mathrm{H}_{2} \mathrm{O}$ : (i) $30 \%$, (ii) 40\%, (iii) 50\%, (iv) 60\%, (v) 80\% (fraction D) and (vi) 100\%. NMR examination of the eluted fractions showed that fraction D contained impure aplysamine-2 $(9.7 \mathrm{mg})$. Fraction $\mathbf{D}$ was dissolved in a minimum amount of pet. ether and loaded onto a glass column packed with DIOL $(10 \mathrm{~mL})$ pre-equilibrated in pet. ether. The loaded column was then eluted with $30 \mathrm{~mL}$ portions of; (i) $100 \%$ pet. ether (ii) $50 \% \mathrm{CH}_{2} \mathrm{Cl}_{2} /$ pet. ether, (iii) $75 \% \mathrm{CH}_{2} \mathrm{Cl}_{2}$ /pet. ether, (iv) $100 \% \mathrm{CH}_{2} \mathrm{Cl}_{2}$, (v) $5 \% \mathrm{EtOAc} / \mathrm{CH}_{2} \mathrm{Cl}_{2}$, (vi) $15 \%$ 
EtOAc $/ \mathrm{CH}_{2} \mathrm{Cl}_{2}$, (vii) $30 \% \mathrm{EtOAc} / \mathrm{CH}_{2} \mathrm{Cl}_{2}$, (viii) $50 \% \mathrm{EtOAc} / \mathrm{CH}_{2} \mathrm{Cl}_{2}$, (ix) $100 \% \mathrm{EtOAc}$, (x) $100 \% \mathrm{MeOH}$. All fractions were collected across 41 test-tubes, and based on TLC examination, test-tubes 39-41 were combined to give $5.1 \mathrm{mg}$ of impure aplysamine-2 (fraction E). Fraction E (5.1 mg) was dissolved in $300 \mu \mathrm{L}$ of HPLC grade MeOH. Ten 30 $\mu \mathrm{L}$ samples were then injected onto an analytical $(250 \mathrm{~mm} \times 4.6 \mathrm{~mm}) \mathrm{C} 18 \mathrm{HPLC}$ column pre-equilibrated with $85 \% \mathrm{MeCN} / \mathrm{H}_{2} \mathrm{O}$, with a flow rate of $1 \mathrm{~mL} / \mathrm{min}$ and $\mathrm{UV}$ detection set to $\lambda_{245 n m}$ and $\lambda_{280 \mathrm{~nm}}$. The eluent between 2.5-2.6 minutes (fraction $\mathbf{F}$ ) was collected and then concentrated to dryness. ${ }^{1} \mathrm{H}$ NMR analysis showed that fraction $\mathbf{F}$ contained 0.6 mg of aplysamine-2 (50).

Fraction $\mathbf{B}(\sim 52.3 \mathrm{mg})$ was dissolved in a minimum amount of pet. ether and loaded onto a glass column packed with DIOL $(30 \mathrm{~mL})$ pre-equilibrated in pet. ether. The loaded column was then eluted with $50 \mathrm{~mL}$ portions of; (i) $100 \%$ pet. ether (ii) $100 \%$ $\mathrm{CH}_{2} \mathrm{Cl}_{2}$, (iii) $50 \% \mathrm{EtOAc} / \mathrm{CH}_{2} \mathrm{Cl}_{2}$, (iv) $100 \% \mathrm{EtOAc}$, (v) $10 \% \mathrm{EtOAc} / \mathrm{MeOH}$, (vi) $30 \%$ EtOAc/MeOH, (vii) 50\% EtOAc/MeOH, (viii) $100 \% \mathrm{MeOH}$. All fractions were collected across 60 test-tubes. Based on NMR and TLC examination, test-tubes 46-52 were combined to give $7.1 \mathrm{mg}$ of impure aerophobin-1 (fraction G). Fraction $\mathbf{G}$ (7.1 mg) was dissolved in $300 \mu \mathrm{L}$ of HPLC grade $\mathrm{MeOH}$. Ten $30 \mu \mathrm{L}$ samples were then injected onto an analytical (250 mm x $4.6 \mathrm{~mm}$ ) C18 HPLC column pre-equilibrated with $85 \% \mathrm{MeCN} / \mathrm{H}_{2} \mathrm{O}$, with a flow rate of $1 \mathrm{~mL} / \mathrm{min}$ and $\mathrm{UV}$ detection set to $\lambda_{245 \mathrm{~nm}}$ and $\lambda_{280 \mathrm{~nm}}$. The eluent between 2.0-2.7 minutes (fraction $\mathbf{H}$ ) was collected and then concentrated to dryness. ${ }^{1} \mathrm{H}$ NMR analysis showed that fraction $\mathbf{G}$ contained $1.2 \mathrm{mg}$ of aerophobin-1 (51).

\section{Aplysamine-2 (50)}

A pale tan semicrystalline solid; all spectroscopic data as previously published. ${ }^{72}$

\section{Aerophobin-1 (51)}

A pale white semicrystalline solid; all spectroscopic data as previously published. ${ }^{73}$ 


\subsection{Investigation of Verongiid Sponge}

\subsubsection{Isolation of Fistularin-3, Aeroplysinin-1 and LL-PAA216}

The sponge (PTN3_46E) was collected by hand using SCUBA from Tu'ungasika Island, Vava'u, Tonga in late November 2009. The sample was frozen immediately and kept at $-18{ }^{\circ} \mathrm{C}$ until extraction. A voucher sample (PTN3_46E) has been deposited and stored in $100 \%$ EtOH, at the School of Chemical and Physical Sciences, Victoria University of Wellington, New Zealand.

The sponge (27 g wet weight) was cut into small pieces and extracted with $\mathrm{MeOH}(2 \mathrm{x} 100$ $\mathrm{mL}$ each) for 24 hours. The second then first methanolic extracts were loaded onto a glass coloumn packed with HP20 beads $(30 \mathrm{~mL})$ pre-equilibrated in $\mathrm{MeOH}$. The combined eluent was then diluted with $\mathrm{H}_{2} \mathrm{O}(100 \mathrm{~mL})$ and passed through the same column. This eluent was further diluted with $\mathrm{H}_{2} \mathrm{O}(200 \mathrm{~mL})$ and passed through the column. The column was then washed with $75 \mathrm{~mL}$ of $\mathrm{H}_{2} \mathrm{O}$. The loaded column was eluted with $120 \mathrm{~mL}$ of increasing concentrations of $\mathrm{Me}_{2} \mathrm{CO}$ in $\mathrm{H}_{2} \mathrm{O}$ : (i) $30 \%$ (fraction A), (ii) $75 \%$ (fraction B) and 100\% (fraction C). Fractions $\mathbf{A}$ and $\mathbf{B}$ were each individually back loaded onto glass columns packed with HP20 beads ( $30 \mathrm{~mL}$ ) pre-equilibrated in $\mathrm{MeOH}$. The columns were then washed with $\mathrm{H}_{2} \mathrm{O}(120 \mathrm{~mL})$ and eluted with $\mathrm{Me}_{2} \mathrm{CO}(120 \mathrm{~mL})$. The eluents were then concentrated to dryness to give $136 \mathrm{mg}$ of fraction $\mathbf{A}, 726.5 \mathrm{mg}$ of fraction $\mathbf{B}$. Fraction C was also concentrated to dryness (105.5 mg). TLC and NMR examination of the resulting fractions showed that the interesting signals were confined to the $30 \%$ and $75 \% \mathrm{Me}_{2} \mathrm{CO} / \mathrm{H}_{2} \mathrm{O}$ fractions.

Fraction $\mathbf{A}(\sim 32.8 \mathrm{mg})$ was dissolved in a minimum amount of $\mathrm{CH}_{2} \mathrm{Cl}_{2}$ and loaded onto a glass column packed with silica gel $(10 \mathrm{~mL})$ pre-equilibrated in $\mathrm{CH}_{2} \mathrm{Cl}_{2}$. The loaded column was then eluted with $30 \mathrm{~mL}$ portions of; (i) $100 \% \mathrm{CH}_{2} \mathrm{Cl}_{2}$, (ii) $5 \% \mathrm{EtOAc} / \mathrm{CH}_{2} \mathrm{Cl}_{2}$, (iii) $15 \% \mathrm{EtOAc} / \mathrm{CH}_{2} \mathrm{Cl}_{2}$, (iv) $30 \% \mathrm{EtOAc} / \mathrm{CH}_{2} \mathrm{Cl}_{2}$, (v) $50 \% \mathrm{EtOAc} / \mathrm{CH}_{2} \mathrm{Cl}_{2}$, (vi) $100 \%$ EtOAc, (vii) 5\% MeOH/EtOAc, (viii) 15\% MeOH/EtOAc, (ix) 30\% MeOH/EtOAc, (x) $100 \% \mathrm{MeOH}$, all fractions were collected in 48 test-tubes and were concentrated to dryness. The fractions were analysed by TLC and fractions 12-17 (fraction D) and 
fractions 28-33 (fraction E) were combined. ${ }^{1} \mathrm{H}$ NMR analysis showed that fraction D contained $8.6 \mathrm{mg}$ of aeroplysinin-1 (53) and fraction E contained 6.2 mg LL-PAA216 (54).

Fraction $\mathbf{B}(\sim 57.9 \mathrm{mg})$ dissolved in $10 \mathrm{~mL}$ of $\mathrm{MeOH}$ and cyclic loaded onto a glass analytical column packed with $5 \mathrm{ml}$ HP20SS pre-equilibrated in MeOH. The loaded column was eluted with $25 \mathrm{~mL}$ of increasing concentrations of $\mathrm{Me}_{2} \mathrm{CO}$ in $\mathrm{H}_{2} \mathrm{O}$ : (i) $30 \%$ (fraction F), (ii) 40\% (fraction G), (iii) 50\%, (iv) 60\% (fraction $\mathbf{H}$ ), (v) 80\%, and (vi) $100 \%$. All fractions were collected in test-tubes and were concentrated to dryness to give $5.3 \mathrm{mg}$ of fraction $\mathbf{F}, 7.4 \mathrm{mg}$ of fraction $\mathbf{G}, 3.3 \mathrm{mg}\left(50 \% \mathrm{Me}_{2} \mathrm{CO} / \mathrm{H}_{2} \mathrm{O}\right.$ fraction), $24.3 \mathrm{mg}$ of fraction $\mathbf{H}, 11.1 \mathrm{mg}\left(80 \% \mathrm{Me}_{2} \mathrm{CO} / \mathrm{H}_{2} \mathrm{O}\right.$ fraction) and $0.8 \mathrm{mg}$ (fraction $100 \% \mathrm{Me}_{2} \mathrm{CO}$ ).

Fraction $\mathbf{F}(5.3 \mathrm{mg})$ was dissolved in a minimum amount of $\mathrm{CH}_{2} \mathrm{Cl}_{2}$ and loaded onto a glass column packed with silica gel $(10 \mathrm{~mL})$ pre-equilibrated in $\mathrm{CH}_{2} \mathrm{Cl}_{2}$. The loaded column was then eluted with $30 \mathrm{~mL}$ portions of; (i) $100 \% \mathrm{CH}_{2} \mathrm{Cl}_{2}$, (ii) $5 \% \mathrm{EtOAc} / \mathrm{CH}_{2} \mathrm{Cl}_{2}$, (iii) $15 \% \mathrm{EtOAc} / \mathrm{CH}_{2} \mathrm{Cl}_{2}$, (iv) $30 \% \mathrm{EtOAc} / \mathrm{CH}_{2} \mathrm{Cl}_{2}$, (v) $50 \% \mathrm{EtOAc} / \mathrm{CH}_{2} \mathrm{Cl}_{2}$, (vi) $75 \%$ EtOAc/ $\mathrm{CH}_{2} \mathrm{Cl}_{2}$, (vii) $100 \% \mathrm{EtOAc}$, (viii) $10 \% \mathrm{MeOH} / \mathrm{EtOAc}$, (ix) $100 \% \mathrm{MeOH}$, all fractions were collected across 42 test-tubes and were concentrated to dryness. The fractions were analysed by TLC and fractions 13-17 (fraction I) and fractions 31-37 (fraction $\mathbf{J}$ ) were combined. ${ }^{1} \mathrm{H}$ NMR analysis showed that fraction $\mathbf{I}$ contained $2.2 \mathrm{mg}$ of aeroplysinin-1 and fraction $\mathbf{J}$ contained $1.8 \mathrm{mg}$ of LL-PAA216 (54).

Fraction $\mathbf{G}(7.4 \mathrm{mg})$ was dissolved in a minimum amount of $\mathrm{CH}_{2} \mathrm{Cl}_{2}$ and loaded onto a glass column packed with silica gel $(10 \mathrm{~mL})$ pre-equilibrated in $\mathrm{CH}_{2} \mathrm{Cl}_{2}$. The loaded column was then eluted with $30 \mathrm{~mL}$ portions of; (i) $100 \% \mathrm{CH}_{2} \mathrm{Cl}_{2}$, (ii) $5 \% \mathrm{EtOAc} / \mathrm{CH}_{2} \mathrm{Cl}_{2}$, (iii) $15 \% \mathrm{EtOAc} / \mathrm{CH}_{2} \mathrm{Cl}_{2}$, (iv) $30 \% \mathrm{EtOAc} / \mathrm{CH}_{2} \mathrm{Cl}_{2}$, (v) $50 \% \mathrm{EtOAc} / \mathrm{CH}_{2} \mathrm{Cl}_{2}$, (vi) $100 \%$ EtOAc, (vii) $5 \% \mathrm{MeOH} / \mathrm{EtOAc}$, (viii) $10 \% \mathrm{MeOH} / \mathrm{EtOAc}$, (ix) $100 \% \mathrm{MeOH}$, all fractions were collected in 42 test-tubes and were concentrated to dryness. The fractions were analysed by TLC and fractions 7-17 (fraction K) and 25-32 (fraction L) were combined. ${ }^{1} \mathrm{H}$ NMR analysis showed that fraction $\mathbf{K}$ contained $0.7 \mathrm{mg}$ of aeroplysinin- 1 and fraction L contained $0.8 \mathrm{mg}$ of LL-PAA216.

Fraction $\mathbf{H}$ (24.3 mg) was dissolved in a minimum amount of $\mathrm{CH}_{2} \mathrm{Cl}_{2}$ and loaded onto 
a glass column packed with silica gel $(10 \mathrm{~mL})$ pre-equilibrated in $\mathrm{CH}_{2} \mathrm{Cl}_{2}$. The loaded column was then eluted with $30 \mathrm{~mL}$ portions of; (i) $100 \% \mathrm{CH}_{2} \mathrm{Cl}_{2}$, (ii) $5 \% \mathrm{EtOAc} / \mathrm{CH}_{2} \mathrm{Cl}_{2}$, (iii) $10 \% \mathrm{EtOAc} / \mathrm{CH}_{2} \mathrm{Cl}_{2}$, (iv) $15 \% \mathrm{EtOAc} / \mathrm{CH}_{2} \mathrm{Cl}_{2}$, (v) $30 \% \mathrm{EtOAc} / \mathrm{CH}_{2} \mathrm{Cl}_{2}$, (vi) $50 \%$ EtOAc/ $\mathrm{CH}_{2} \mathrm{Cl}_{2}$, (vii) $100 \%$ EtOAc, (viii) $5 \% \mathrm{MeOH} / \mathrm{EtOAc}$, (ix) $100 \% \mathrm{MeOH}$, all fractions were collected across 43 test-tubes and were concentrated to dryness. The fractions were analysed by TLC and fractions 26-31 (fraction M) were combined. ${ }^{1} \mathrm{H}$ NMR analysis showed that fraction M contained $18 \mathrm{mg}$ of fistularin-3 (52). Fractions D, $\mathbf{I}$, and $\mathbf{K}$ were combined to yield $11.5 \mathrm{mg}$ of aeroplysinin-1 (53) and fractions $\mathbf{E}, \mathbf{J}$, and $\mathbf{L}$ were combined to give $8.8 \mathrm{mg}$ of LL-PAA216 (54).

Fistularin-3 (52)

Colourless solid; all spectroscopic data as previously published. ${ }^{64}$

\section{Aeroplysinin-1 (53)}

Colourless solid; all spectroscopic data as previously published. ${ }^{74}$

\section{LL-PAA216 (54)}

Colourless solid; all spectroscopic data as previously published. ${ }^{75}$

\subsection{Investigation of a Poecilosclerid Sponge}

\subsubsection{Isolation of of Makaluvamine $G$ and Prianosin B}

Unidentified black sponge (PTN4_10A), was collected by hand using SCUBA from Fakafotulā, Vava'u, Tonga in late November 2009. The sample was frozen immediately and kept at $-18^{\circ} \mathrm{C}$ until extraction. A voucher sample (PTN4_10A) has been deposited and stored in 100\% EtOH, at the School of Chemical and Physical Sciences, Victoria University of Wellington, New Zealand.

The sponge (21 g wet weight) was cut into small pieces and extracted with $\mathrm{MeOH}(2 \times$ 
$100 \mathrm{~mL}$ each) for 24 hours. The second then first methanolic extracts were loaded onto a glass column packed with HP20 beads (30 mL) pre-equilibrated in $\mathrm{MeOH}$. The combined eluent was then diluted with $\mathrm{H}_{2} \mathrm{O}(200 \mathrm{~mL})$ and passed through the same column. This eluent was further diluted with $\mathrm{H}_{2} \mathrm{O}(400 \mathrm{~mL})$ and passed through the column. The column was then washed with $100 \mathrm{~mL}$ of $\mathrm{H}_{2} \mathrm{O}$. The loaded column was eluted with $100 \mathrm{~mL}$ of increasing concentrations of $\mathrm{Me}_{2} \mathrm{CO}$ in $\mathrm{H}_{2} \mathrm{O}$ : (i) $30 \%$ (fraction $\mathrm{A}$ ), (ii) $75 \%$ (fraction B) and (iii) 100\% (fraction C). Fraction A and B were each individually backloaded onto glass columns packed HP20 beads $(30 \mathrm{~mL})$ pre-equilibrated in $\mathrm{MeOH}$. The columns were then washed with $\mathrm{H}_{2} \mathrm{O}(100 \mathrm{~mL})$ and eluted with $\mathrm{Me}_{2} \mathrm{CO}(100 \mathrm{~mL})$. The eluents were then concentrated to dryness to give $90.6 \mathrm{mg}$ of fraction $\mathbf{A}, 68 \mathrm{mg}$ of fraction B. Fraction C was also concentrated to dryness $(60.8 \mathrm{mg})$. TLC and NMR examination of the resulting fractions showed that the interesting signals were confined to the $75 \%$ $\mathrm{Me}_{2} \mathrm{CO}$ in $\mathrm{H}_{2} \mathrm{O}$ fraction.

Fraction $\mathbf{B}(\sim 17.9 \mathrm{mg})$ was dissolved in $10 \mathrm{~mL}$ of $\mathrm{MeOH}$ and cyclic loaded onto a glass analytical column packed with $5 \mathrm{~mL}$ HP20SS pre-equilibrated in MeOH. The loaded column was eluted with $30 \mathrm{~mL}$ of increasing concentrations of $\mathrm{MeOH}$ in $\mathrm{H}_{2} \mathrm{O}$ : (i) $30 \%$, (ii) $40 \%$, (iii) $50 \%$, (iv) $60 \%$, (v) $80 \%$ and (vi) 100\%. All fractions were concentrated to dryness and based on TLC, the $80 \% \mathrm{MeOH} / \mathrm{H}_{2} \mathrm{O}$ and $100 \% \mathrm{MeOH}$ fractions were combined to give $9.2 \mathrm{mg}$ (fraction D). Fraction $\mathbf{D}$ was dissolved in a minimum amount of $\mathrm{CH}_{2} \mathrm{Cl}_{2}$ and loaded onto a glass column packed with DIOL (10 mL) pre-equilibrated in $\mathrm{CH}_{2} \mathrm{Cl}_{2}$. The loaded column was then eluted with $30 \mathrm{~mL}$ portions of; (i) $100 \% \mathrm{CH}_{2} \mathrm{Cl}_{2}$, (ii) $5 \% \mathrm{EtOAc} / \mathrm{CH}_{2} \mathrm{Cl}_{2}$, (iii) $10 \% \mathrm{EtOAc} / \mathrm{CH}_{2} \mathrm{Cl}_{2}$, (iv) $15 \% \mathrm{EtOAc} / \mathrm{CH}_{2} \mathrm{Cl}_{2}$, (v) $30 \%$ EtOAc/ $\mathrm{CH}_{2} \mathrm{Cl}_{2}$, (vi) $50 \% \mathrm{EtOAc} / \mathrm{CH}_{2} \mathrm{Cl}_{2}$, (vii) $100 \% \mathrm{EtOAc}$, (viii) $5 \% \mathrm{EtOAc} / \mathrm{MeOH}$, (ix) 30\% EtOAc/MeOH, (x) 50\% EtOAc/MeOH, (xi) 100\% MeOH. All fractions were collected across 60 test-tubes. The fractions were analysed by TLC and fractions 45-56 (fraction $\mathbf{E}$ ) were combined. NMR analysis showed that fraction D contained impure 3.8 mg of makaluvamine G. Fraction E (3.8 mg) was dissolved in $300 \mu \mathrm{L}$ of HPLC grade $\mathrm{MeOH}$. Ten $30 \mu \mathrm{L}$ samples were then injected onto a analytical $(250 \mathrm{~mm} \times 4.6 \mathrm{~mm}) \mathrm{C} 18$ HPLC column pre-equilibrated with $85 \% \mathrm{MeCN} / \mathrm{H}_{2} \mathrm{O}$, with a flow rate of $1 \mathrm{~mL} / \mathrm{min}$ and UV detection set to $\lambda_{245 \mathrm{~nm}}$ and $\lambda_{280 \mathrm{~nm}}$. The eluent between 4.3-4.7 minutes (fraction $\mathbf{F}$ ) was collected and then concentrated to dryness. ${ }^{1} \mathrm{H}$ NMR analysis showed that fraction $\mathbf{F}$ 
contained $0.8 \mathrm{mg}$ of makaluvamine $\mathrm{G}(\mathbf{5 5})$.

Fraction $\mathbf{B}(\sim 50 \mathrm{mg})$ was dissolved in a minimum amount of $\mathrm{CH}_{2} \mathrm{Cl}_{2}$ and loaded onto a glass column packed with DIOL (30 mL) pre-equilibrated in $\mathrm{CH}_{2} \mathrm{Cl}_{2}$. The loaded column was then eluted with $50 \mathrm{~mL}$ portions of; (i) $100 \% \mathrm{CH}_{2} \mathrm{Cl}_{2}$, (ii) $50 \% \mathrm{EtOAc} / \mathrm{CH}_{2} \mathrm{Cl}_{2}$, (iii) $75 \%$ EtOAc/ $\mathrm{CH}_{2} \mathrm{Cl}_{2}$, (iv) $100 \%$ EtOAc, (v) $10 \% \mathrm{MeOH} / \mathrm{EtOAc}$, (vi) $20 \% \mathrm{MeOH} / \mathrm{EtOAc}$, (vii) $40 \% \mathrm{MeOH} / \mathrm{EtOAc}$, (viii) $60 \% \mathrm{MeOH} / \mathrm{EtOAc}$, (ix) $80 \% \mathrm{MeOH} / \mathrm{EtOAc}$, (x) $100 \%$ $\mathrm{MeOH}$, all fractions were collected across 78 test-tubes and were concentrated to dryness. The fractions were analysed by TLC and fractions 21-22 (fraction G) were combined. NMR analysis showed that fraction $\mathbf{G}$ contained $0.6 \mathrm{mg}$ of prianosin B (56).

\section{Makaluvamine G (55)}

Greenish-black solid; all spectroscopic data as previously published. ${ }^{79}$

\section{Prianosin B (56)}

Red crystalline solid; all spectroscopic data as previously published. ${ }^{82}$ 
Appendix A

\section{Existing Marine Chemistry Sponge Screening Protocol}

\section{Preparation}

\section{Equipment Needed (per Screen)}

- 1 x Screen column loaded with $80 \mathrm{~mL}$ of HP20 equilibrated in distilled $\mathrm{MeOH}$

- 1 x Backloading column loaded with $40 \mathrm{~mL}$ of $\mathrm{HP} 20$ equilibrated in distilled $\mathrm{MeOH}$

\section{NMR Standard Preparation}

Prepare a standard of 1,3,5-tribromobenzene in $\mathrm{CDCl}_{3}$ by dissolving $78.9 \mathrm{mg}$ of 1,3,5tribromobenzene in $5 \mathrm{~mL}$ of $\mathrm{CDCl}_{3}$.

\section{Procedure}

1. Voucher Sample Preparation

- Take a voucher specimen of ca. $10 \mathrm{~g}$ of sponge material ensuring that both the ectoderm and the endoderm are represented.

- Label and store the voucher sample in $75 \%$ IPA in $\mathrm{H}_{2} \mathrm{O}$.

2. Extraction

- Extract ca. $100 \mathrm{~g}$ of sponge material in $400 \mathrm{~mL}$ of distilled $\mathrm{MeOH}$ overnight. 
- Filter the first extract and set aside. Re-extract the sponge material (and any filter paper/celite as necessary) in $400 \mathrm{~mL}$ of distilled $\mathrm{MeOH}$ overnight.

- Filter the second extract.

- Keep all sponge material (and any filter paper/celite as necessary) until the screen is complete at which time it may be discarded.

3. Cyclic Loading

- Pass the second extract through the screen column with a flow rate of ca. 10 $\mathrm{mL} / \mathrm{min}$.

- Pass the first extract through the screen column with a flow rate of ca. $10 \mathrm{~mL} / \mathrm{min}$. Combine the eluent with that of the second extract.

- Dilute the combined eluents with $800 \mathrm{~mL}$ of distilled $\mathrm{H}_{2} \mathrm{O}$. Pass the diluted eluents back through the screen column at a flow rate of ca. $10 \mathrm{~mL} / \mathrm{min}$.

- Dilute the eluent with 1.6 L of distilled $\mathrm{H}_{2} \mathrm{O}$. Pass the diluted eluent back through the screen column at a flow rate of ca. $10 \mathrm{~mL} / \mathrm{min}$.

- The eluent should be kept until the screen is complete at which time it may be discarded.

4. Elution

- Elute the screen column with $250 \mathrm{~mL}$ of distilled $\mathrm{H} 2 \mathrm{O}$ at a flow rate of ca. 10 $\mathrm{mL} / \mathrm{min}$. The $\mathrm{H} 2 \mathrm{O}$ eluent can be discarded immediately.

- Elute the screen column with $250 \mathrm{~mL}$ of $30 \%$ distilled $\mathrm{Me}_{2} \mathrm{CO}$ in distilled $\mathrm{H}_{2} \mathrm{O}$ (75 $\mathrm{mL} \mathrm{Me}_{2} \mathrm{CO}$ to $175 \mathrm{~mL} \mathrm{H}_{2} \mathrm{O}$ ) at a flow rate of ca. $10 \mathrm{~mL} / \mathrm{min}$.

- Elute the screen column with $250 \mathrm{~mL}$ of $75 \%$ distilled $\mathrm{Me}_{2} \mathrm{CO}$ in distilled $\mathrm{H}_{2} \mathrm{O}$ (187.5 $\mathrm{mL} \mathrm{Me}_{2} \mathrm{CO}$ to $62.5 \mathrm{~mL} \mathrm{H}_{2} \mathrm{O}$ ) at a flow rate of ca. $10 \mathrm{~mL} / \mathrm{min}$. 
- Elute the screen column with $250 \mathrm{~mL}$ of distilled $\mathrm{Me}_{2} \mathrm{CO}$ at a flow rate of ca. 10 $\mathrm{mL} / \mathrm{min}$.

5. Backloading the $75 \%$ Acetone Fraction

- Dilute the $75 \% \mathrm{Me}_{2} \mathrm{CO}$ fraction with $250 \mathrm{~mL}$ of distilled $\mathrm{H}_{2} \mathrm{O}$. Pass the diluted eluent through the backloading column at a flow rate of ca. $8 \mathrm{~mL} / \mathrm{min}$.

- Dilute the eluent with $500 \mathrm{~mL}$ of distilled $\mathrm{H}_{2} \mathrm{O}$. Pass the diluted eluent back through the backloading column at a flow rate of ca. $8 \mathrm{~mL} / \mathrm{min}$.

- The eluent should be kept until the screen is complete at which time it may be discarded.

- Elute the backloading column with $150 \mathrm{~mL}$ of distilled $\mathrm{Me}_{2} \mathrm{CO}$.

6. Processing the $75 \%$ Acetone Fraction

- Evaporate the $\mathrm{Me}_{2} \mathrm{CO}$ eluent of the backloading column to dryness and transfer to a pre-weighed sample vial. Evaporate to dryness and record the mass.

- Sub-sample approximately $30 \mathrm{mg}$ of material for NMR analysis if necessary.

- Prepare an NMR sample in ca. $700 \mu \mathrm{L}$ of $\mathrm{CD}_{3} \mathrm{OD}$ in a $5 \mathrm{~mm}$ NMR tube.

- Add $10 \mu \mathrm{L}$ of the 1,3,5-tribromobenzene standard (representing $507 \mathrm{nmol}$ of 1,3,5tribromobenzene) to the NMR tube.

7. NMR Analysis of the $75 \%$ Acetone Fraction

- Run a ${ }^{1} \mathrm{H}$ spectrum of the sample on the $600 \mathrm{MHz}$ instrument using the standard Screen1H parameter set. (Experiment time: ca. 4 min)

- Make a note Standard Added in the sample text. 
- Run a COSY spectrum of the sample using the standard ScreenCOSY parameter set. (Experiment time: ca. $20 \mathrm{~min}$ )

- Run an HSQC spectrum of the sample using the standard ScreenHSQC parameter set. (Experiment time: ca. $4 \mathrm{~h}$ )

- Process appropriately and export HSQC phasefile.

- Add HSQC phasefile to HSQC mask.

- Apply HSQC mask to HSQC phasefile.

8. Assigning Hit Values to the Screen

- Threshold set at 3\%.

- Signal strength

- An arbitrary value indicating how the strength of the interesting peaks.

- Weak - 1. Medium - 2. Strong - 3 (remember to consider the subsampling factor if necessary).

- Number of interesting peaks

-- Indicates how many red peaks in the HSQC. Something exhibiting more than 20 non-masked peaks will score a 10.

- Uniqueness of interesting peaks

- An arbitrary value indicating whether non-masked peaks represent something interesting (1-10).

- Available mass 
- The total mass of the available sponge material (including that used for the screen) in $\mathrm{kg}$ is multiplied by 10 and rounded to the nearest integer. If more than 1 $\mathrm{kg}$ of sponge material is available the score is 10 .

- Recollectability

- Collected locally -3 . Collected from Northland -2 . Other -1 .

- Sum all 5 hit values. A score of 20 would be considered average.

9. Backloading the $30 \%$ Acetone Fraction

- Dilute the $30 \% \mathrm{Me}_{2} \mathrm{CO}$ fraction with $250 \mathrm{~mL}$ of distilled $\mathrm{H}_{2} \mathrm{O}$. Pass the diluted eluent through the backloading column at a flow rate of ca. $8 \mathrm{~mL} / \mathrm{min}$.

- Dilute the eluent with $500 \mathrm{~mL}$ of distilled $\mathrm{H}_{2} \mathrm{O}$. Pass the diluted eluent back through the backloading column at a flow rate of ca. $8 \mathrm{~mL} / \mathrm{min}$.

- The eluent should be kept until the screen is complete at which time it may be discarded.

- Elute the backloading column with $150 \mathrm{~mL}$ of distilled $\mathrm{MeOH}$.

10. Processing the $30 \%$ Acetone Fraction

- Evaporate the $\mathrm{MeOH}$ eluent of the backloading column to dryness and transfer to a pre-weighed sample vial. Evaporate to dryness and record the mass.

- Sub-sample approximately $30 \mathrm{mg}$ of material for NMR analysis if necessary.

- Prepare an NMR sample in ca. $\mu 700 \mathrm{~L}$ of $\mathrm{CD}_{3} \mathrm{OD}$ in a $5 \mathrm{~mm}$ NMR tube.

11. NMR Analysis of the $30 \%$ Acetone Fraction 
- Run a ${ }^{1} \mathrm{H}$ spectrum of the sample on the $600 \mathrm{MHz}$ instrument using the standard Screen ${ }^{1} \mathrm{H}$ parameter set. (Experiment time: ca. $4 \mathrm{~min}$ )

12. Processing the $100 \%$ Acetone Fraction

- Evaporate the $\mathrm{Me}_{2} \mathrm{CO}$ eluent of the screen column to dryness and transfer to a preweighed sample vial. Evaporate to dryness and the record mass.

- Sub-sample approximately $30 \mathrm{mg}$ of material for NMR analysis if necessary.

- Prepare an NMR sample in ca. $700 \mu \mathrm{L}$ of $\mathrm{CDCl}_{3}$ in a $5 \mathrm{~mm}$ NMR tube.

13. NMR Analysis of the $100 \%$ Acetone Fraction

- Run a ${ }^{1} \mathrm{H}$ spectrum of the sample on the $600 \mathrm{MHz}$ instrument using the standard Screen ${ }^{1} \mathrm{H}$ parameter set. (Experiment time: ca. $4 \mathrm{~min}$ ) 
Appendix B

\section{Isoluffariellolide Spectra}

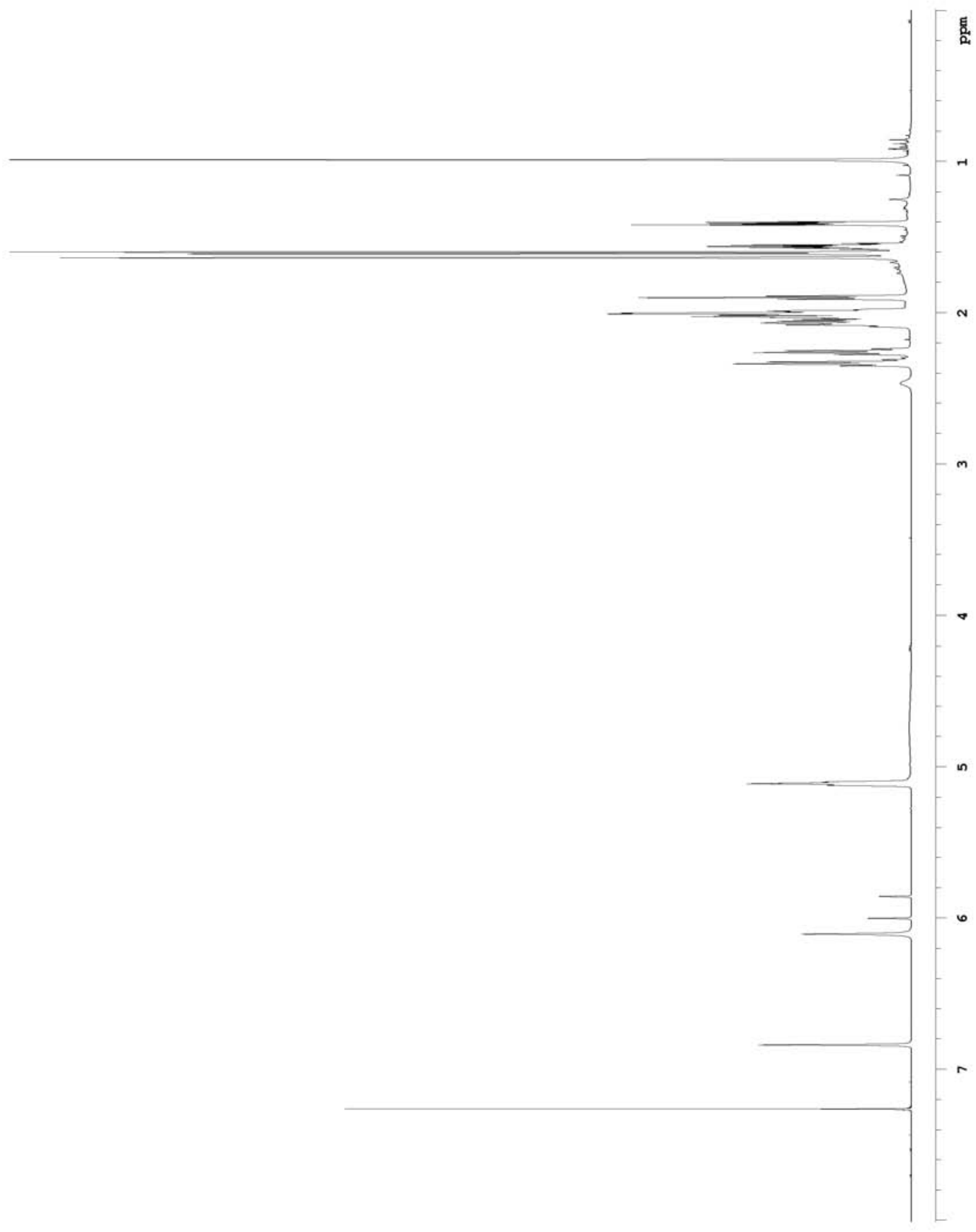

${ }^{1} \mathrm{H}$ NMR spectrum of isoluffariellolide (46) $\left(600 \mathrm{MHz}, \mathrm{CDCl}_{3}\right.$ ) 


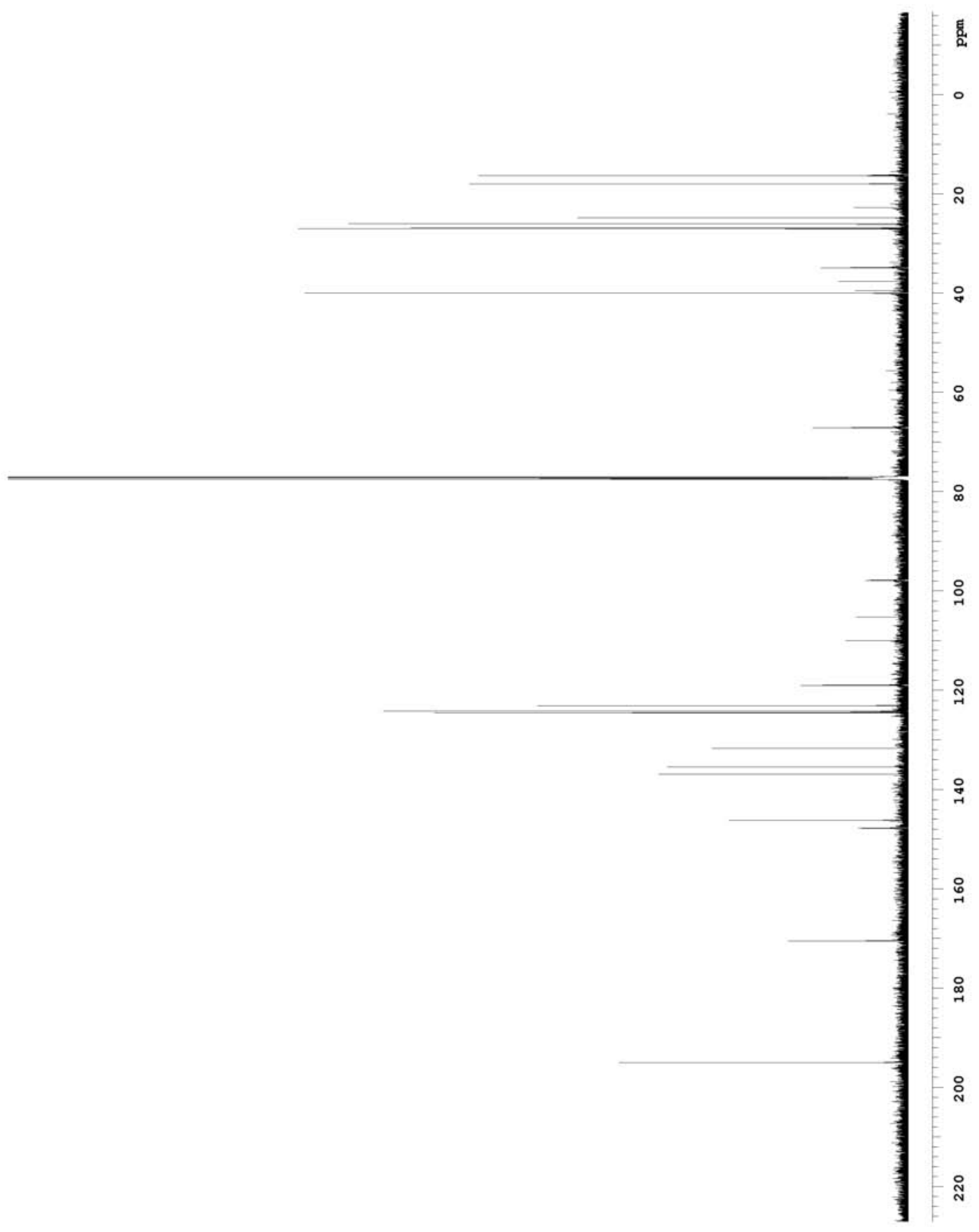

${ }^{13} \mathrm{C}$ spectrum of isoluffariellolide $(\mathbf{4 6})\left(150 \mathrm{MHz}, \mathrm{CDCl}_{3}\right)$ 


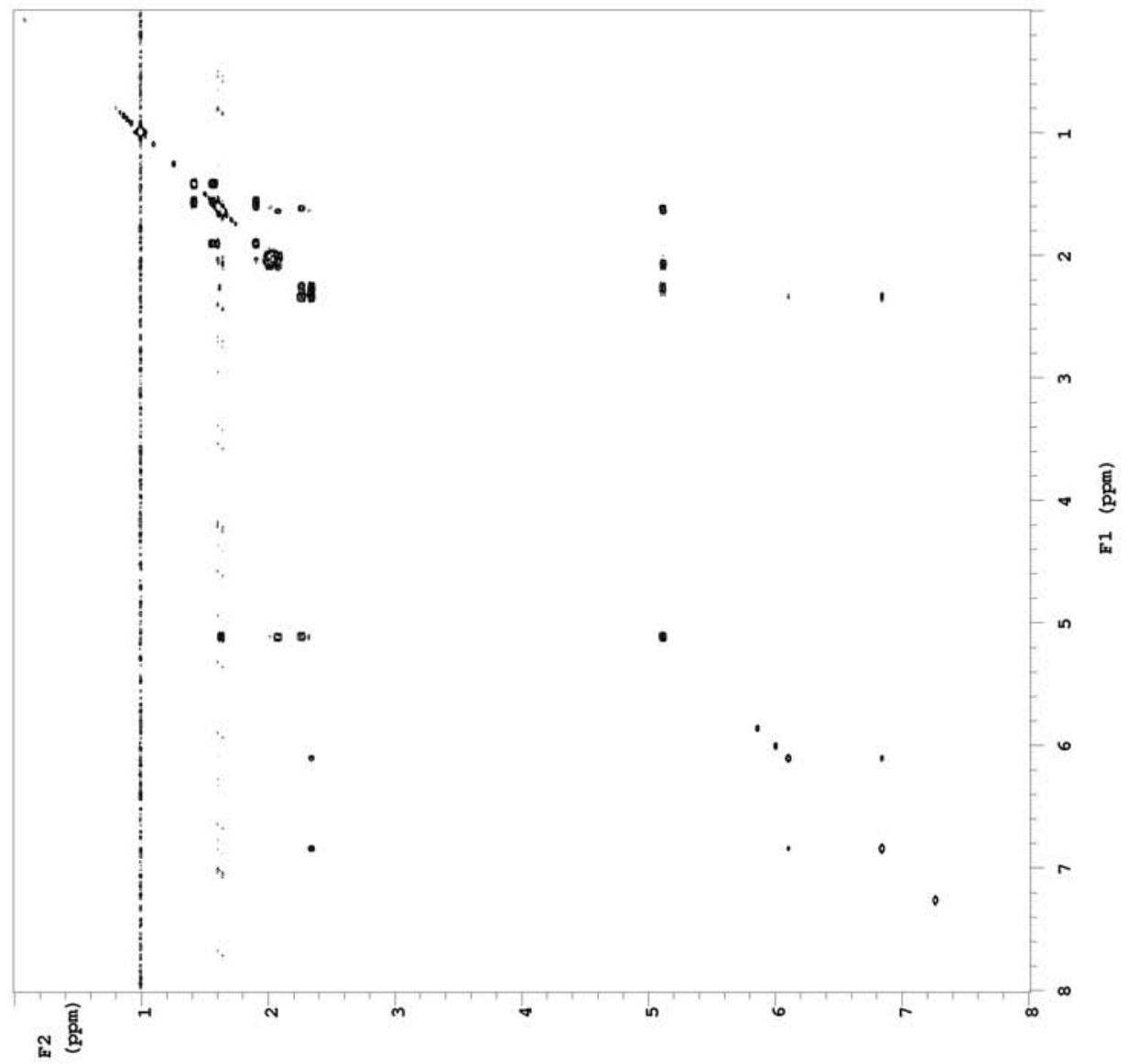

COSY spectrum of isoluffariellolide (46) $\left(600 \mathrm{MHz}, \mathrm{CDCl}_{3}\right)$ 


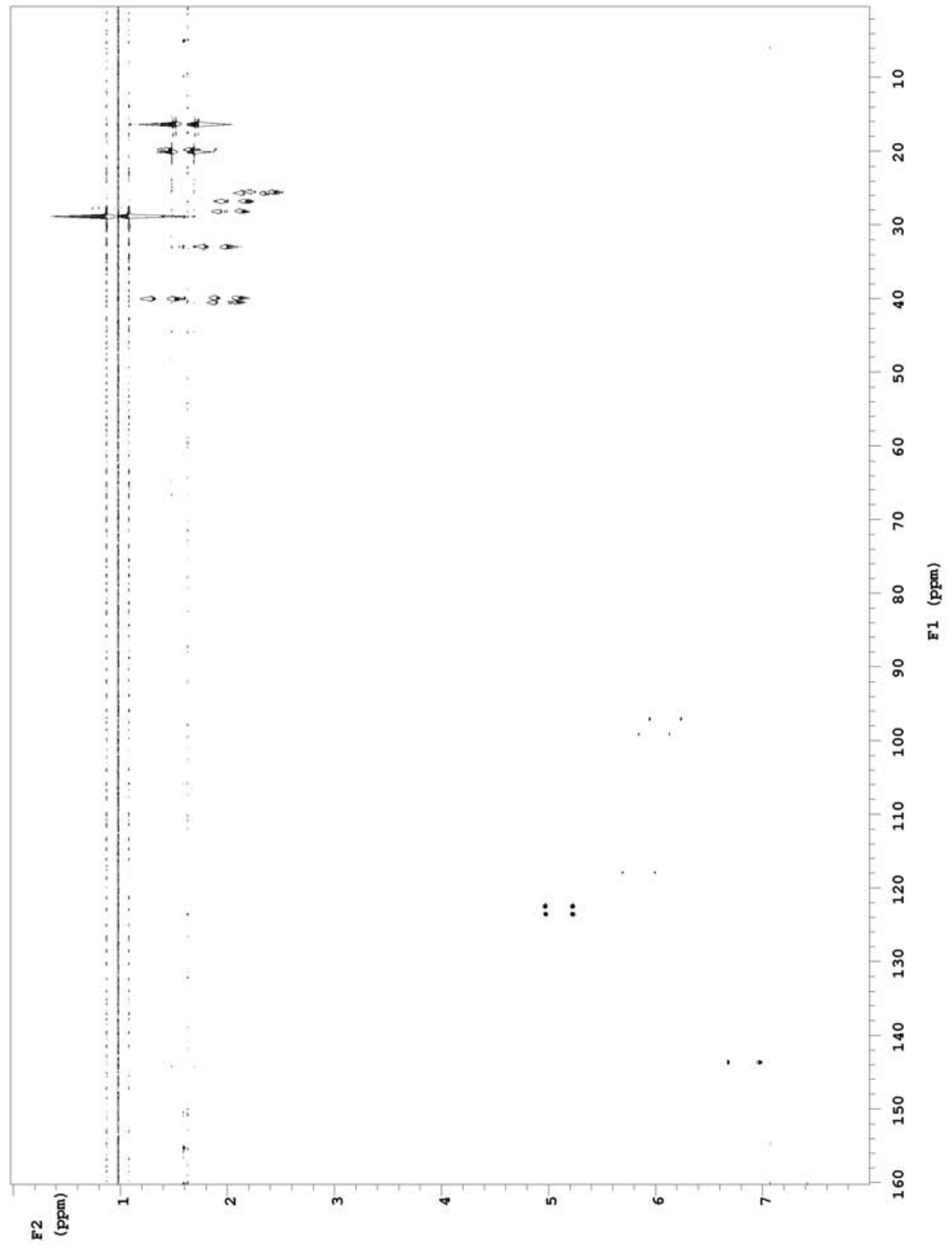

Coupled HSQC spectrum of isoluffariellolide (46) $\left(600 \mathrm{MHz}, \mathrm{CDCl}_{3}\right)$ 


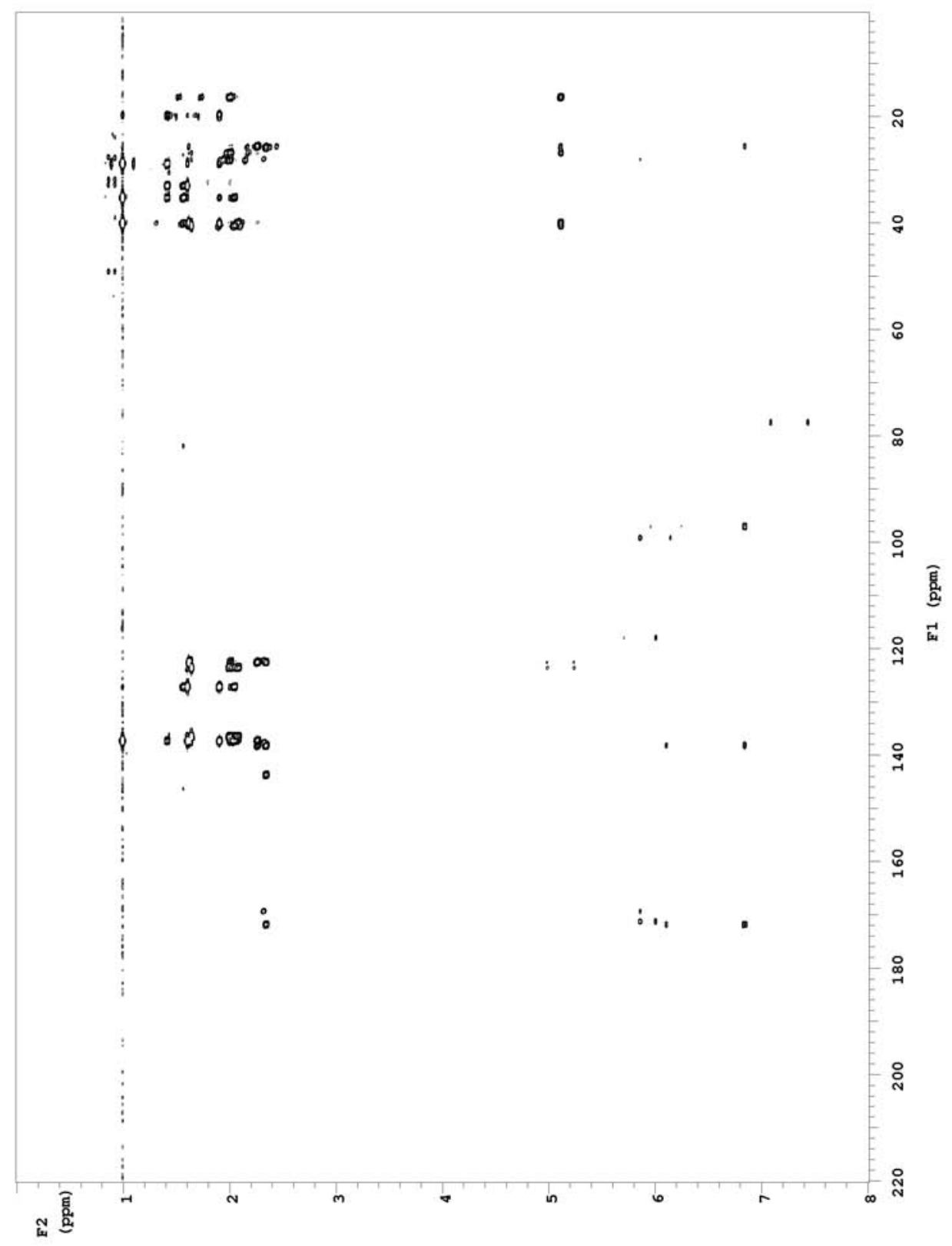

HMBC spectrum of isoluffariellolide (46) $\left(600 \mathrm{MHz}, \mathrm{CDCl}_{3}\right)$ 


\section{1-O-Methylisoluffariellolide Spectra}

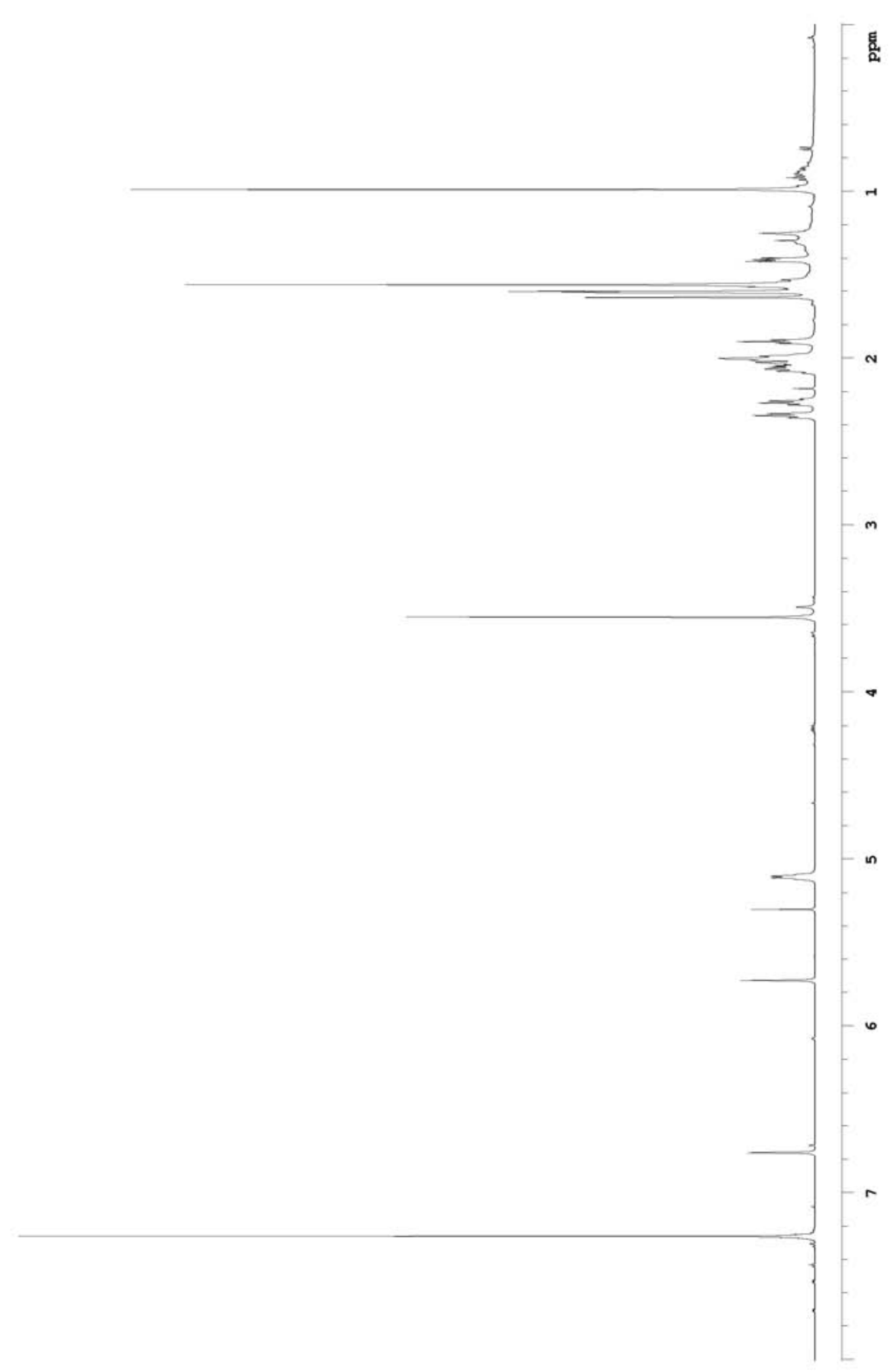

${ }^{1} \mathrm{H}$ NMR spectrum of 1-O-methylisoluffariellolide (47) $\left(600 \mathrm{MHz}, \mathrm{CDCl}_{3}\right.$ ) 


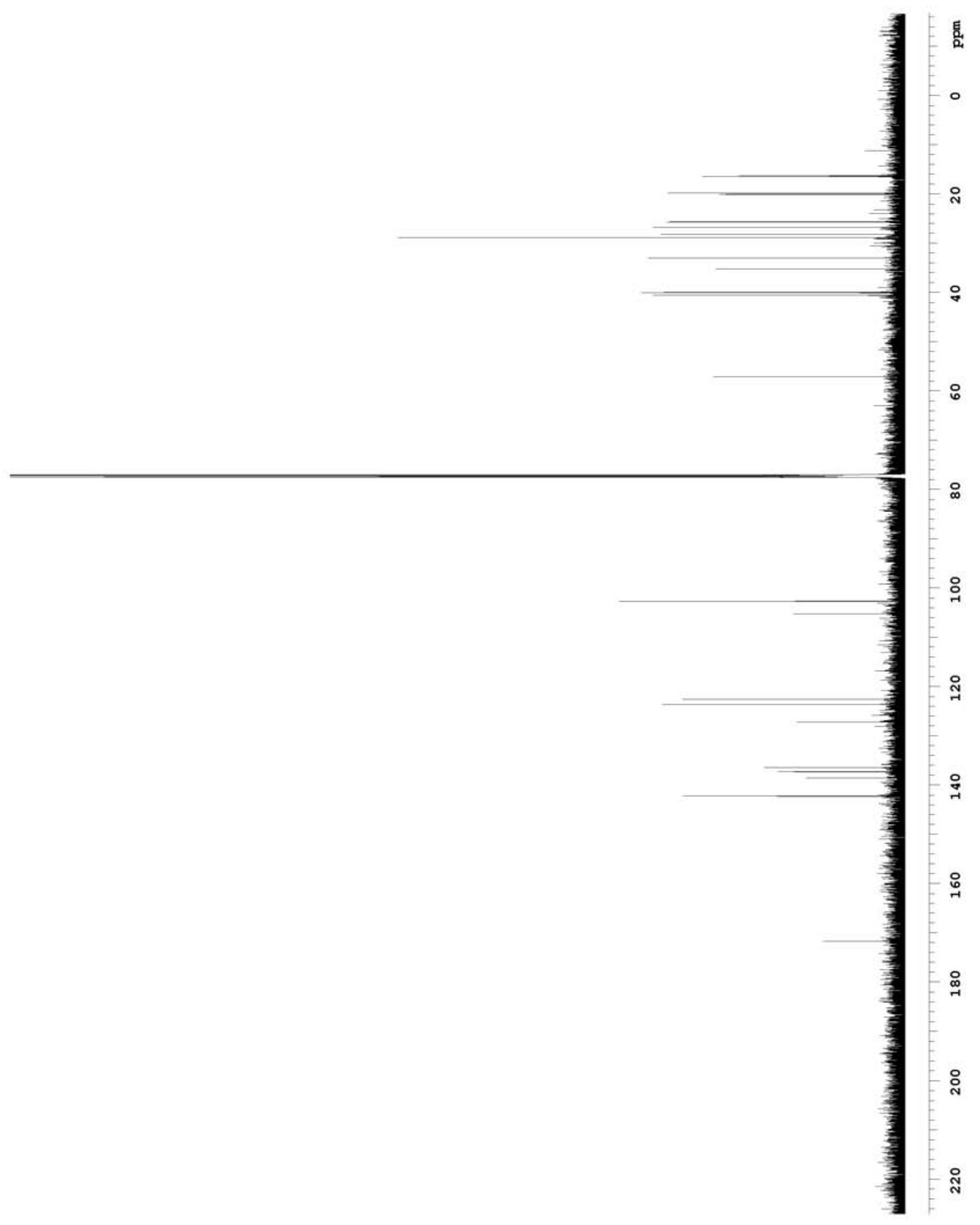

${ }^{13} \mathrm{C}$ spectrum of $1-O$-methylisoluffariellolide $(47)\left(150 \mathrm{MHz}, \mathrm{CDCl}_{3}\right)$ 


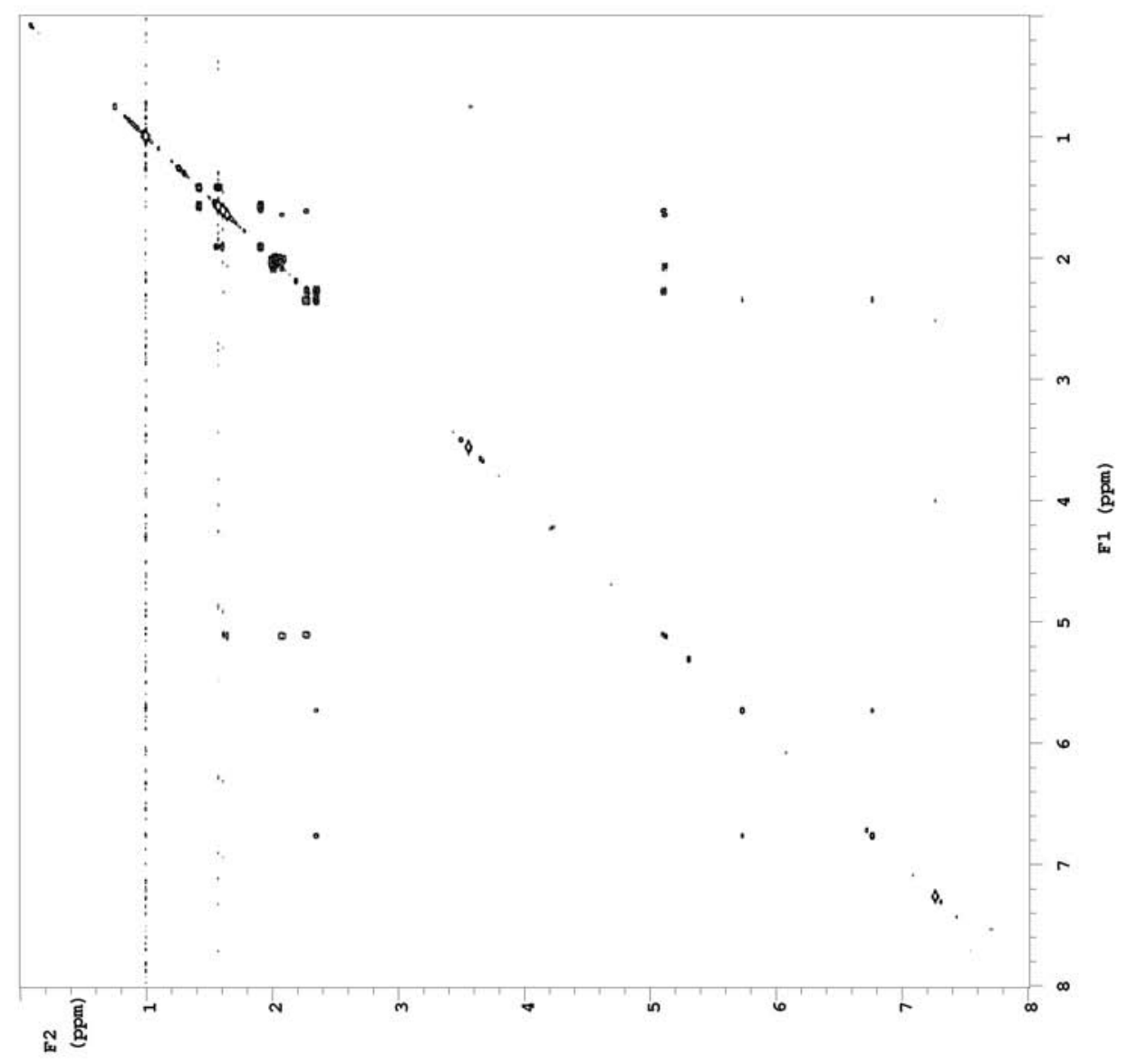

COSY spectrum of 1-O-methylisoluffariellolide (47) $\left(600 \mathrm{MHz}, \mathrm{CDCl}_{3}\right)$ 


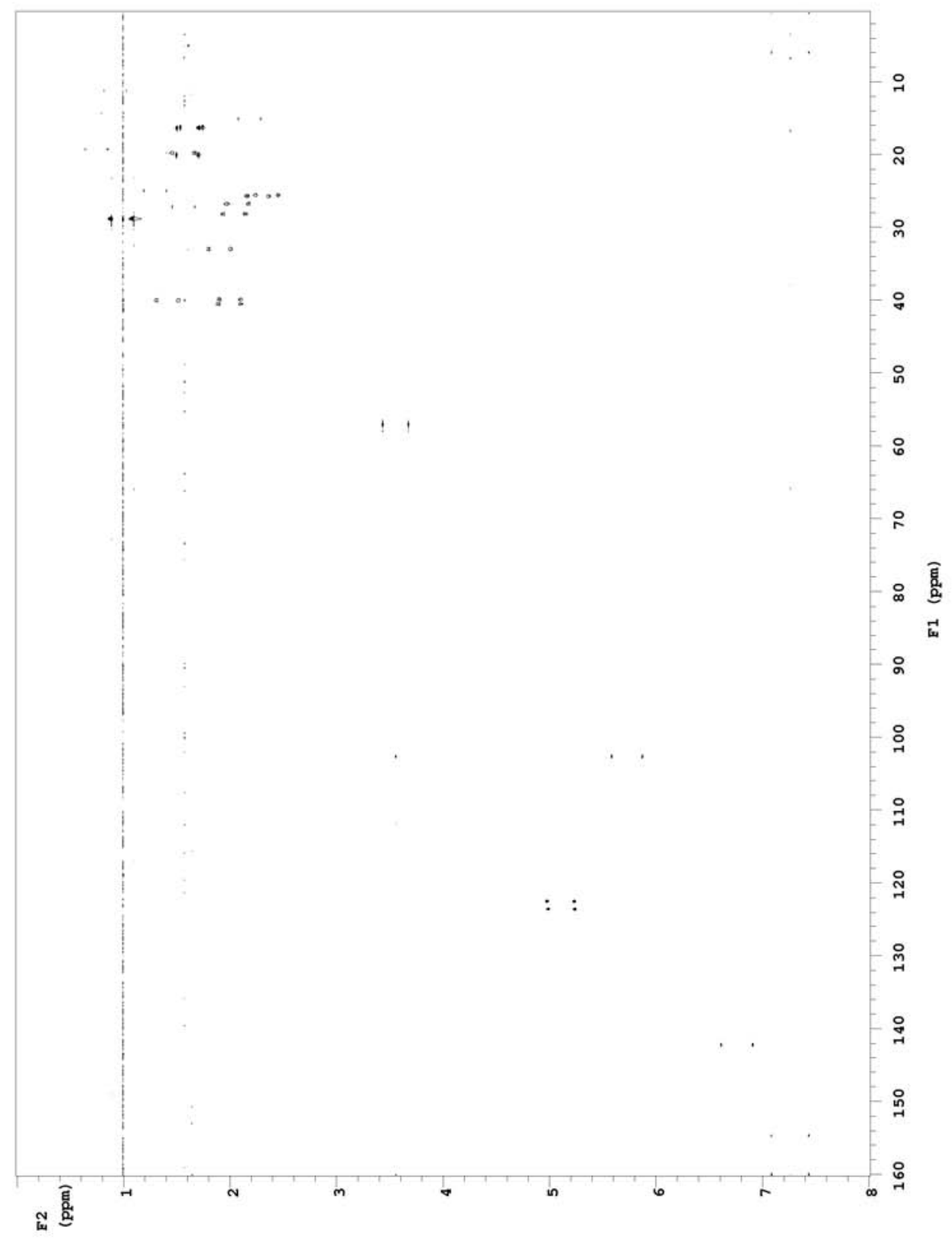

Coupled HSQC spectrum of 1-O-methylisoluffariellolide (47) $\left(600 \mathrm{MHz}, \mathrm{CDCl}_{3}\right)$ 


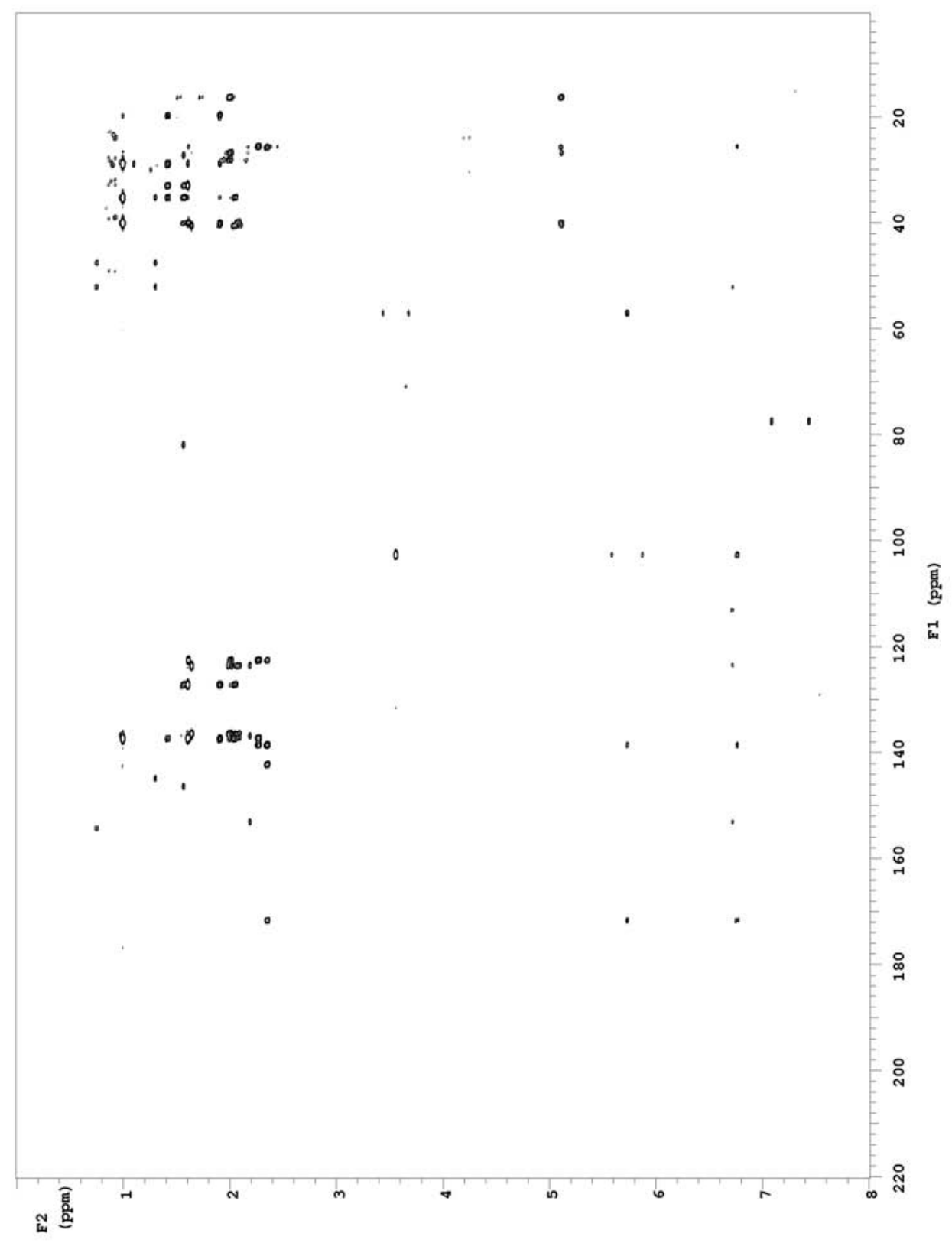

HMBC spectrum of 1-O-methylisoluffariellolide (47) $\left(600 \mathrm{MHz}, \mathrm{CDCl}_{3}\right)$ 
Appendix D

Secothorectolide Spectra

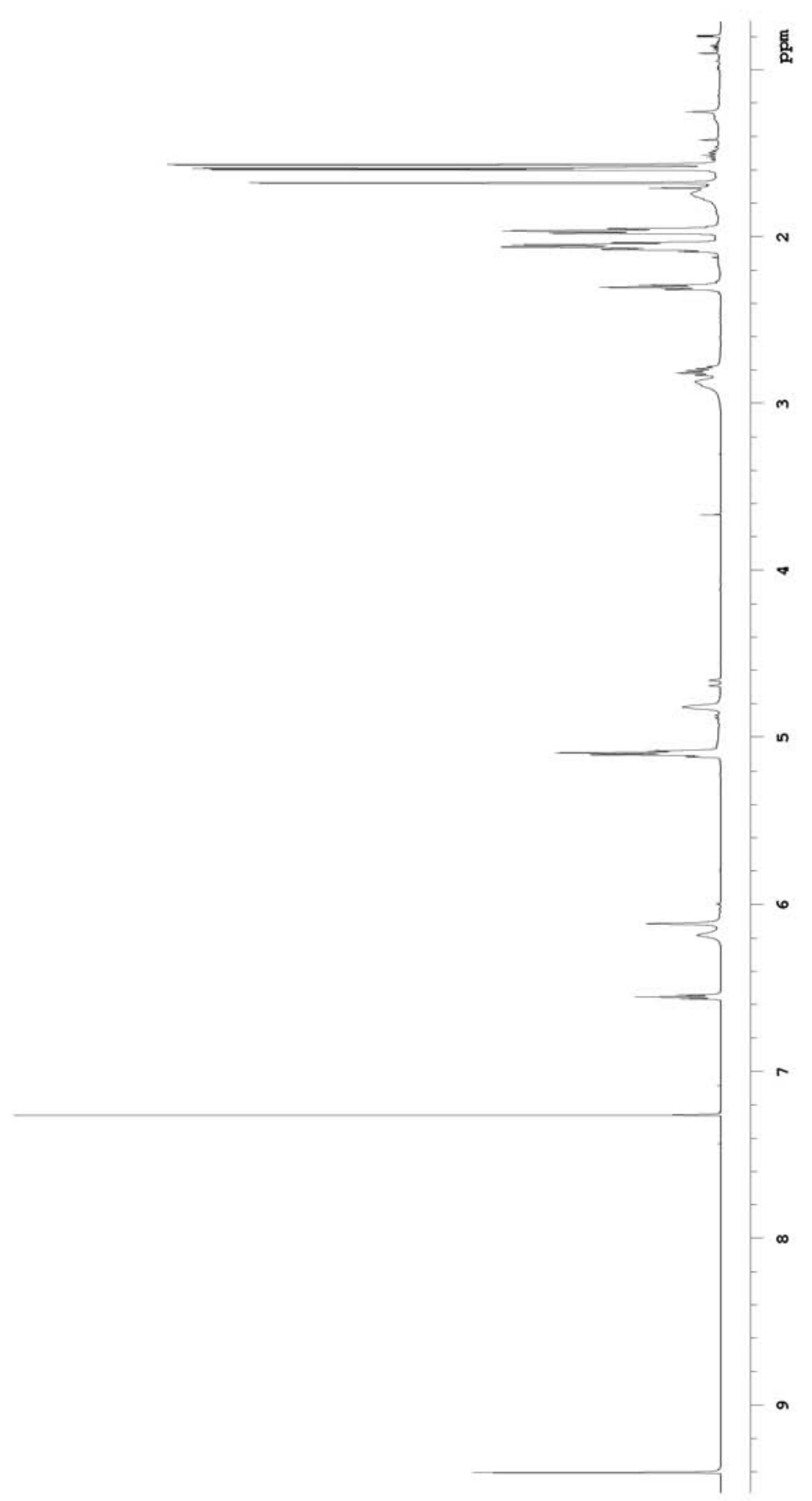

${ }^{1} \mathrm{H}$ NMR spectrum of secothorectolide (49) $\left(600 \mathrm{MHz}, \mathrm{CDCl}_{3}\right.$ ) 


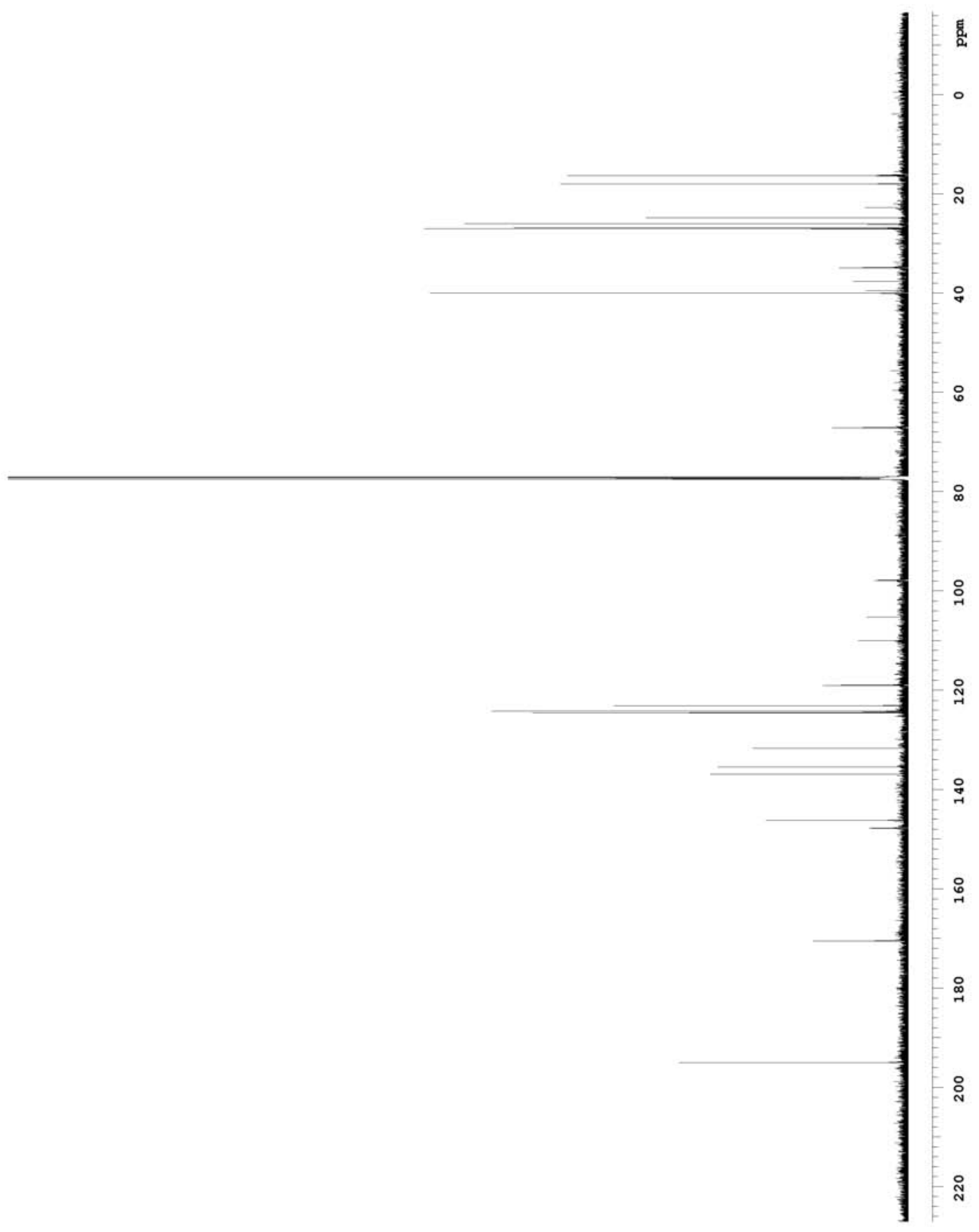

${ }^{13} \mathrm{C}$ spectrum of secothorectolide $(49)\left(150 \mathrm{MHz}, \mathrm{CDCl}_{3}\right)$ 


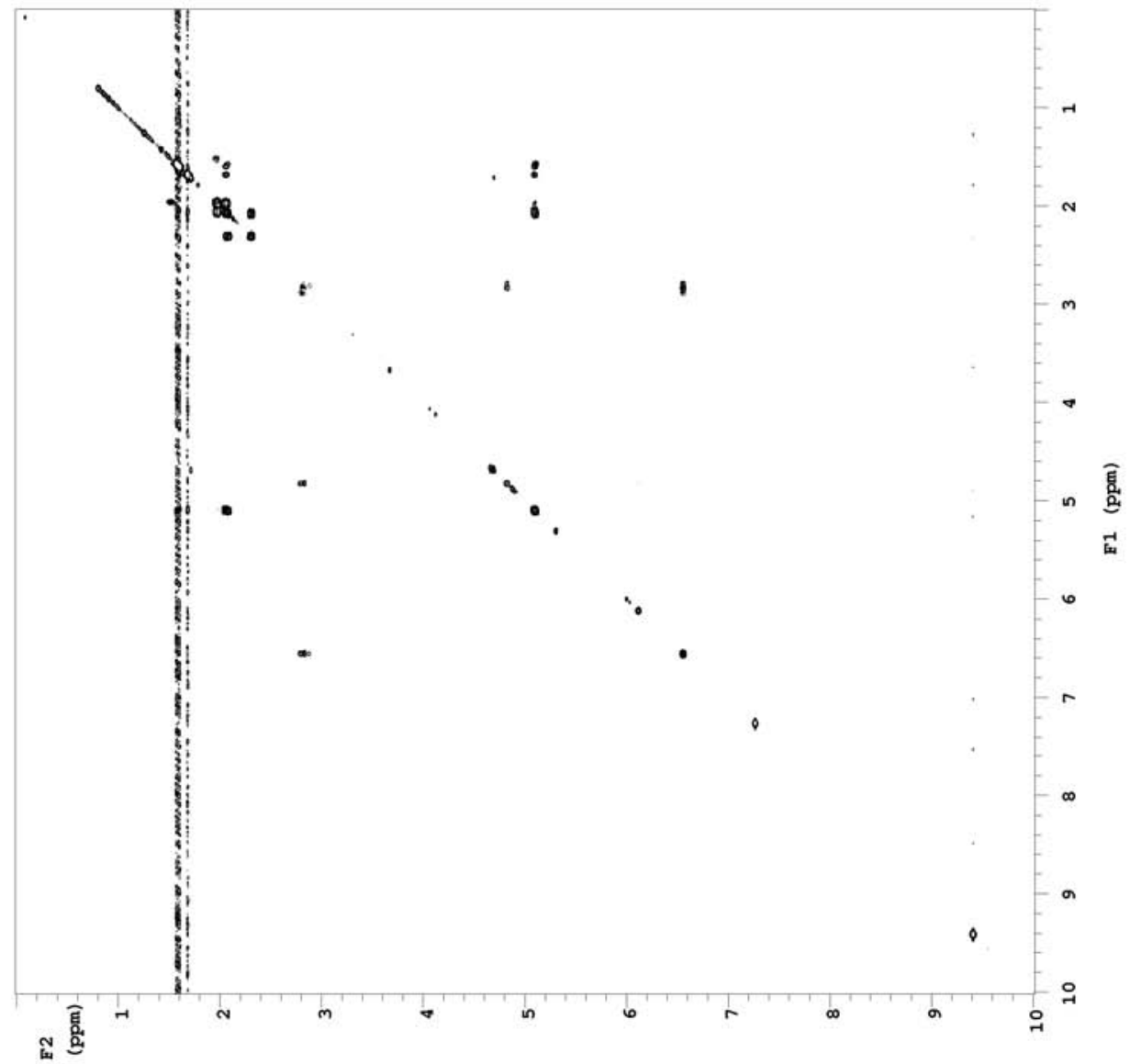

COSY spectrum of secothorectolide (49) $\left(600 \mathrm{MHz}, \mathrm{CDCl}_{3}\right)$ 


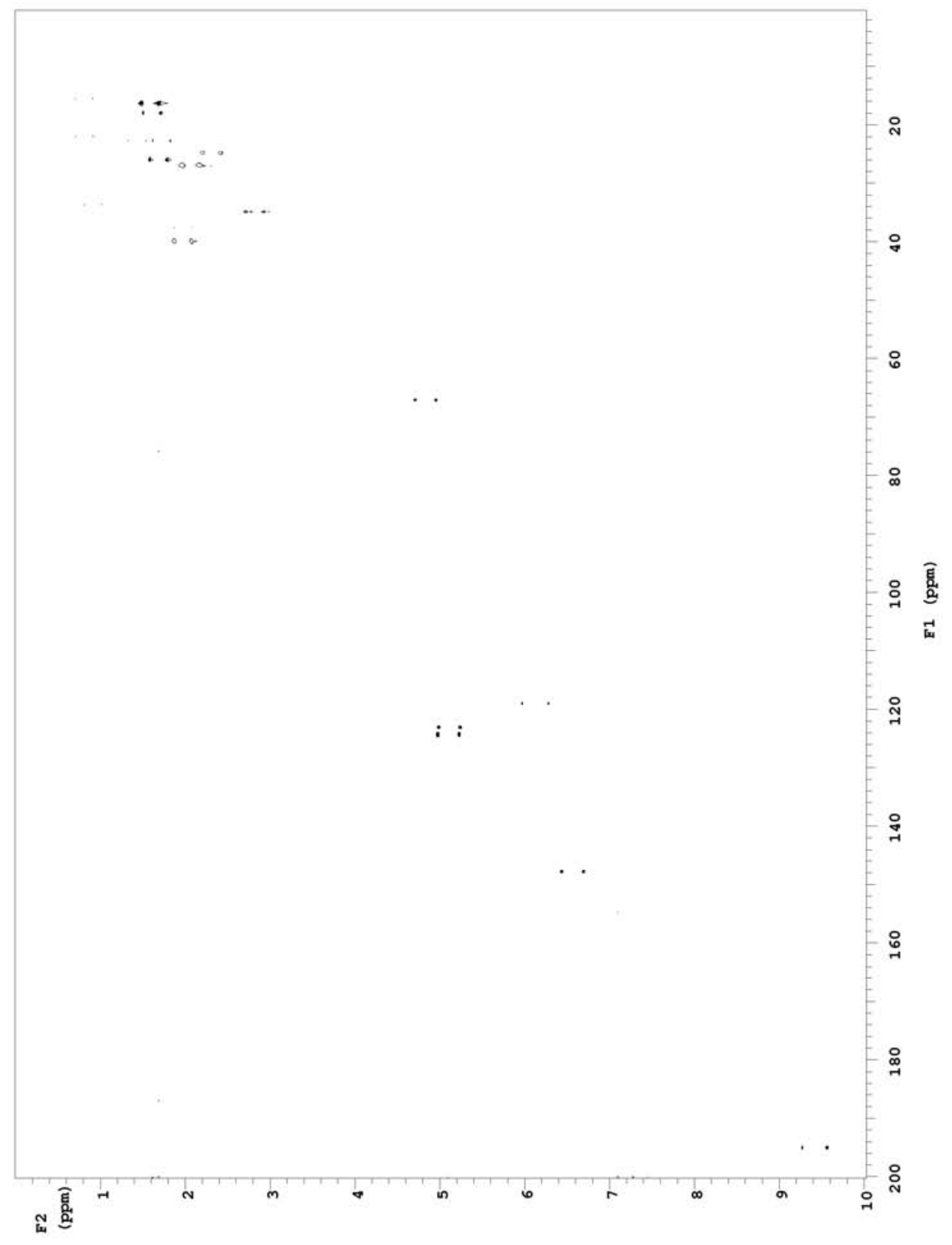

Coupled HSQC spectrum of secothorectolide (49) $\left(600 \mathrm{MHz}, \mathrm{CDCl}_{3}\right)$ 


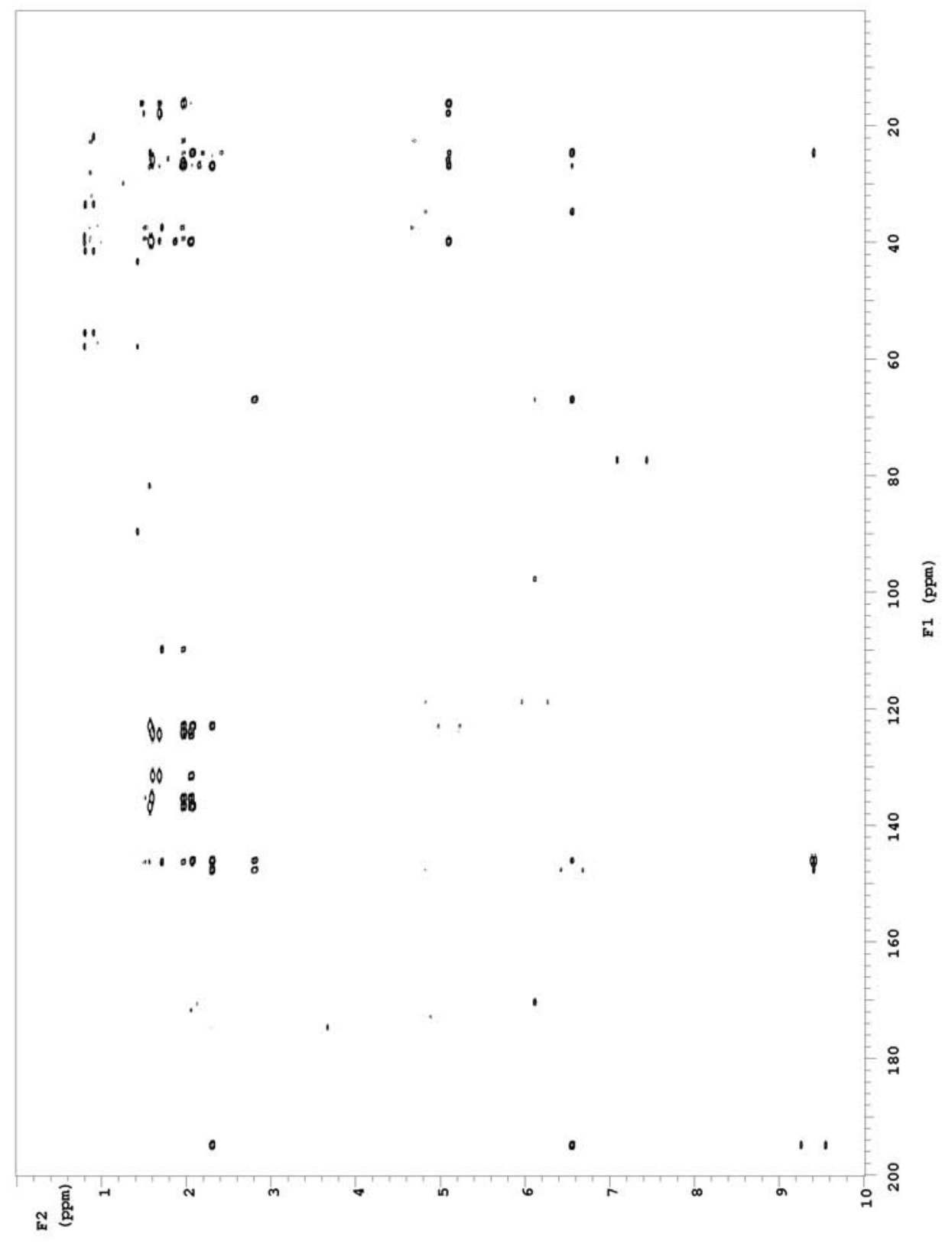

HMBC spectrum of secothorectolide (49) (600 $\mathrm{MHz} \mathrm{CDCl}_{3}$ ) 
Appendix E

\section{Fistularin-3 Spectra}

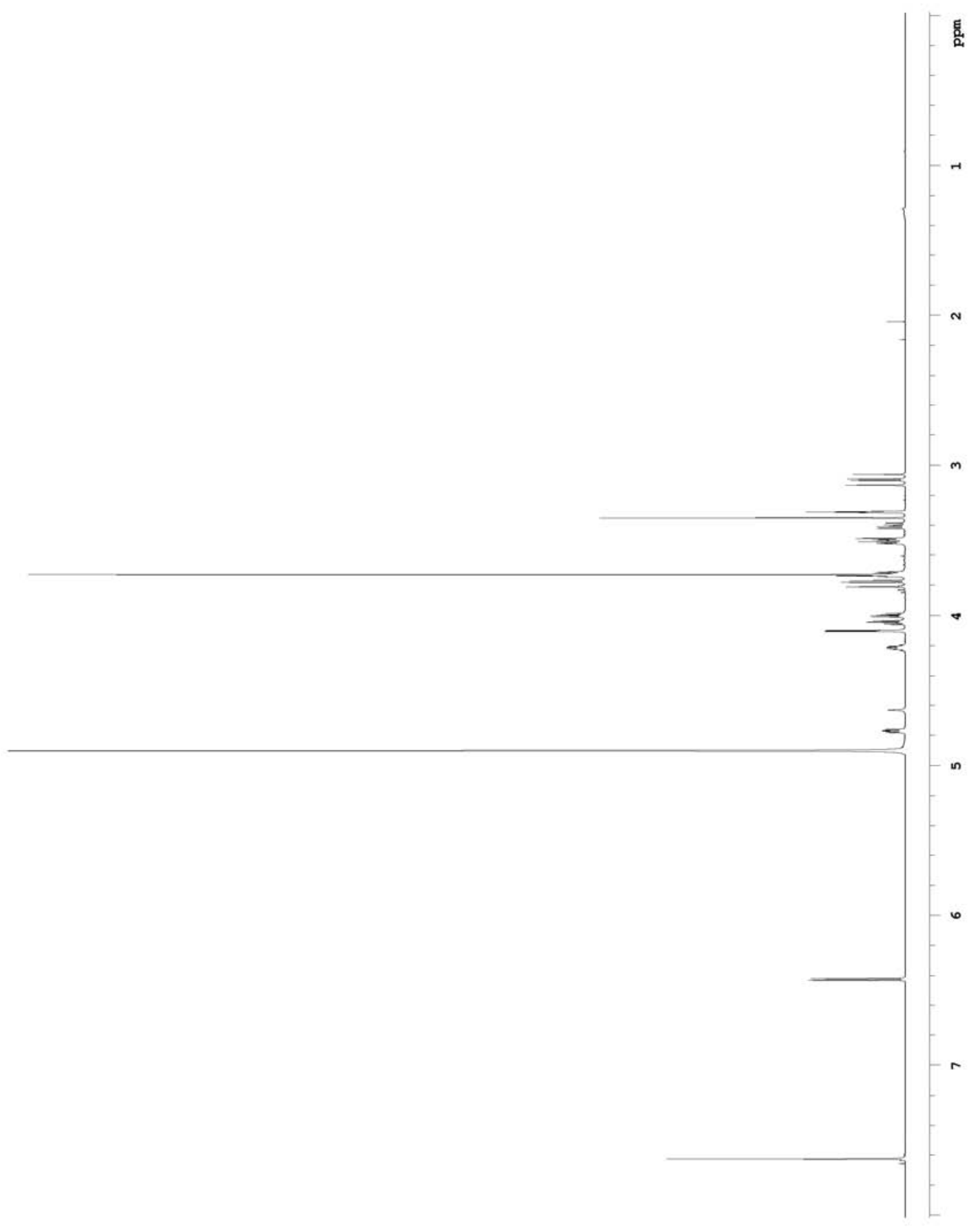

${ }^{1} \mathrm{H}$ NMR spectrum of fistularin-3 (52) $\left(600 \mathrm{MHz}, \mathrm{CD}_{3} \mathrm{OD}\right)$ 


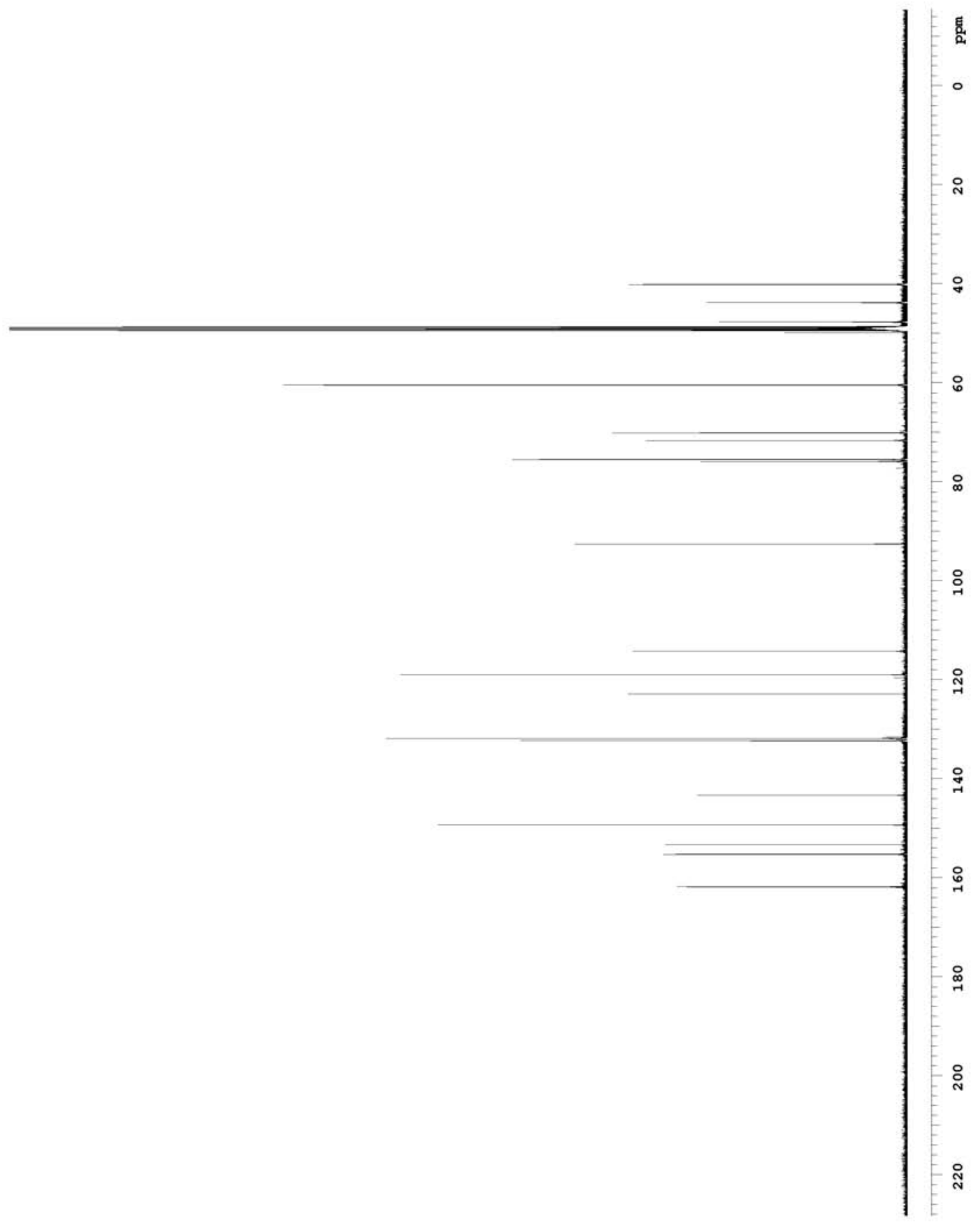

${ }^{13} \mathrm{C}$ spectrum of fistularin-3 (52) $\left(150 \mathrm{MHz}, \mathrm{CD}_{3} \mathrm{OD}\right)$ 


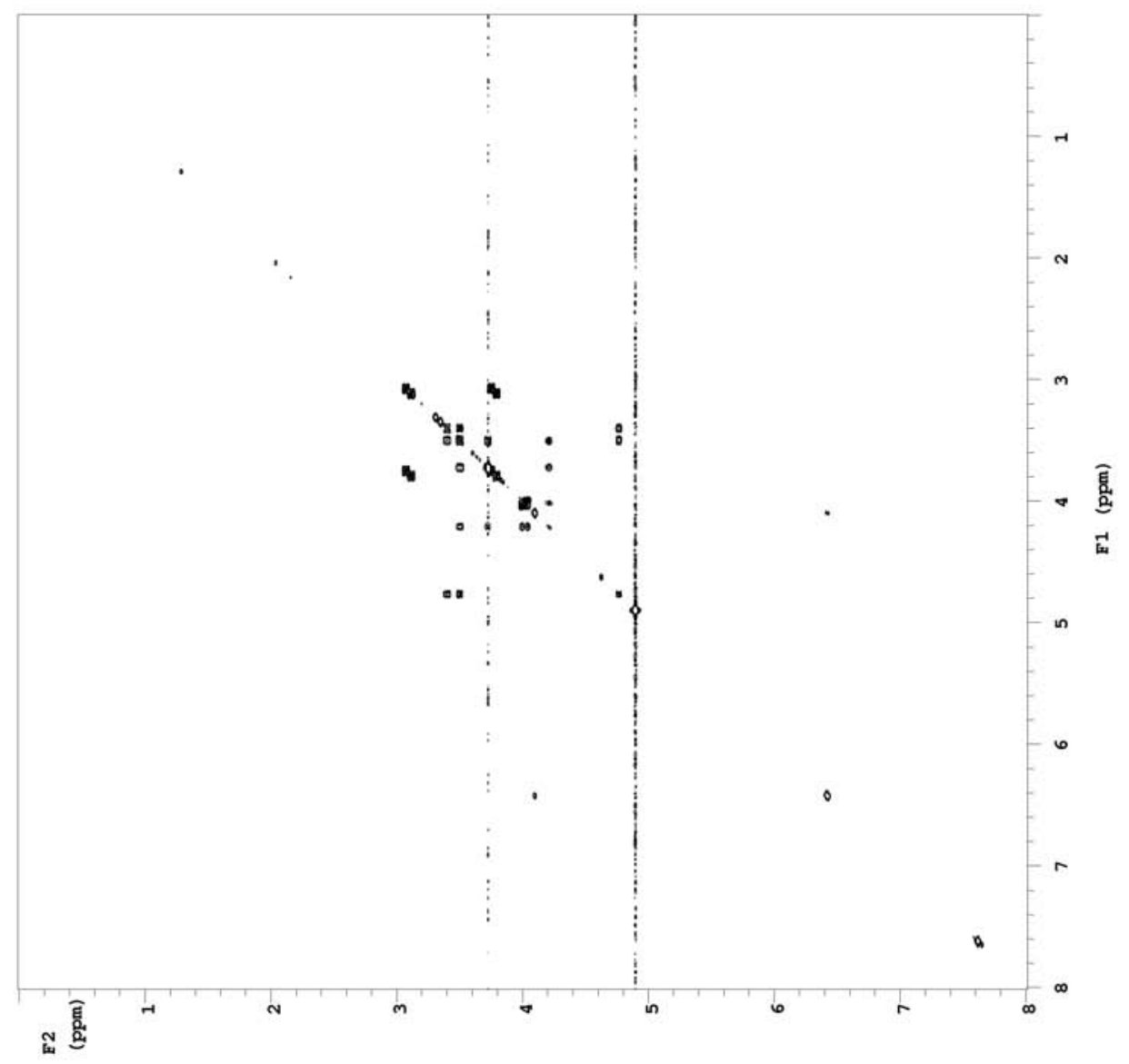

COSY spectrum of fistularin-3 (52) $\left(600 \mathrm{MHz}, \mathrm{CD}_{3} \mathrm{OD}\right)$ 


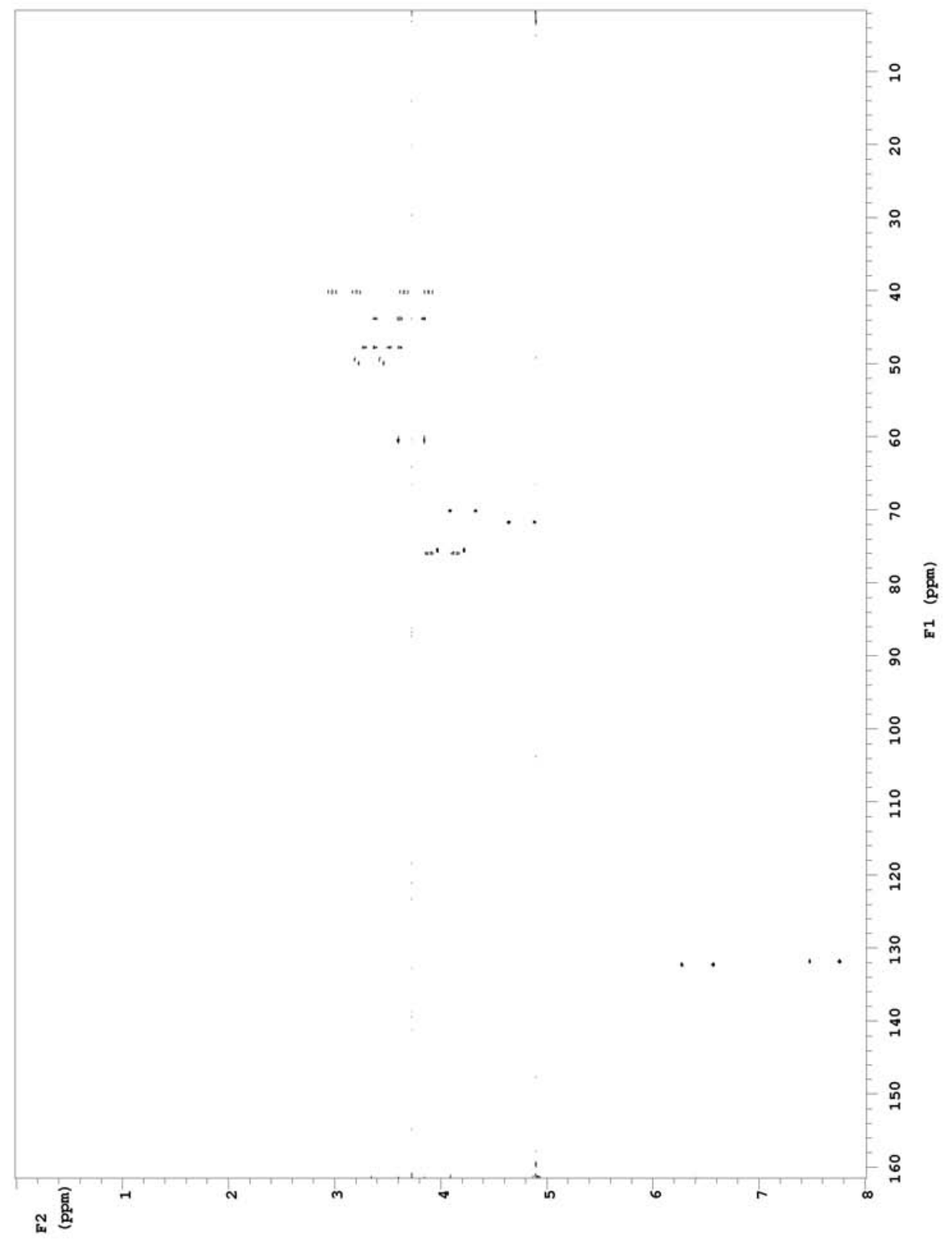

Coupled HSQC spectrum of fistularin-3 (52) (600 MHz, $\left.\mathrm{CD}_{3} \mathrm{OD}\right)$ 


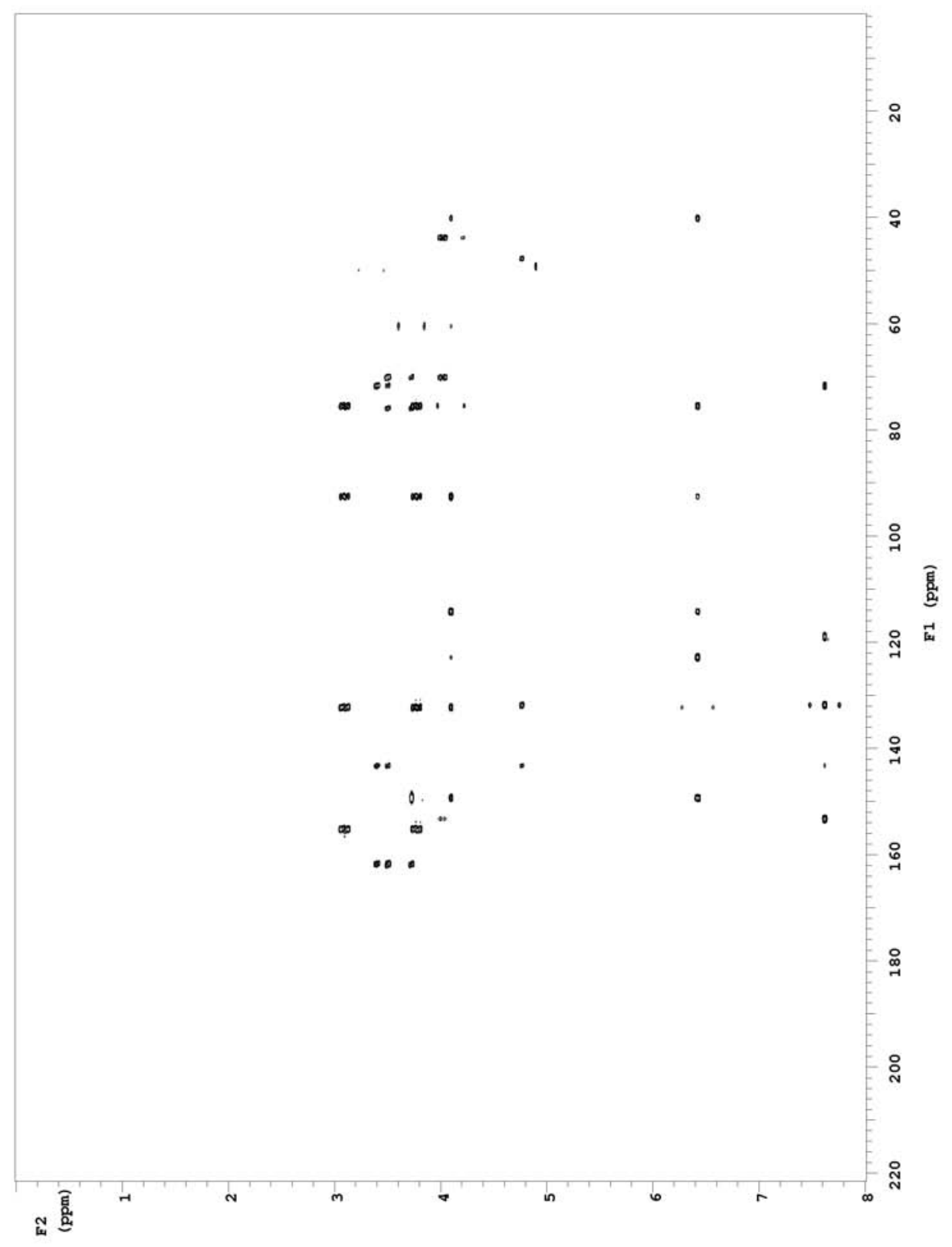

HMBC spectrum of fistularin-3 (52) $\left(600 \mathrm{MHz}, \mathrm{CD}_{3} \mathrm{OD}\right)$ 
Appendix $F$

\section{Aeroplysinin-1 Spectra}

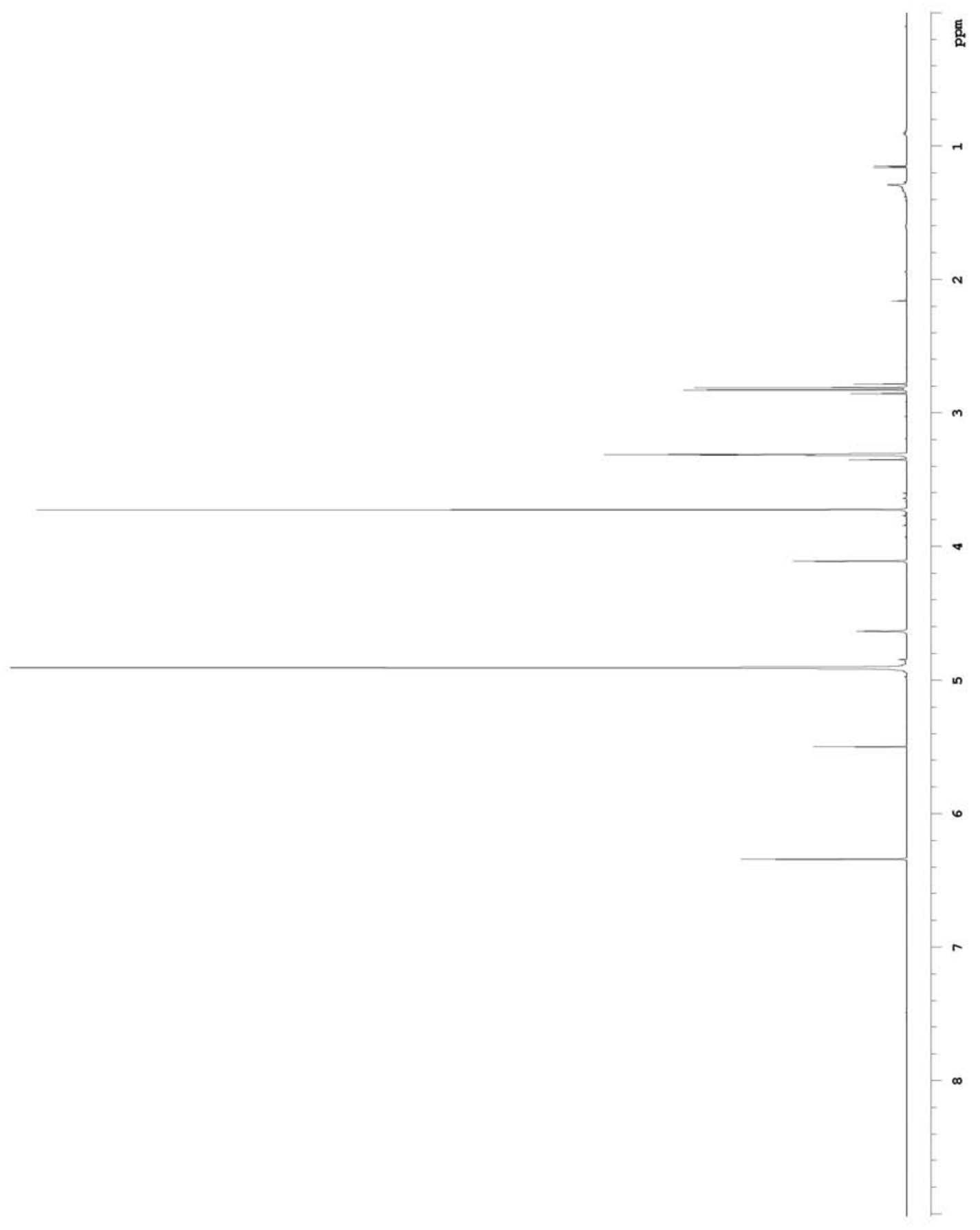

${ }^{1} \mathrm{H}$ NMR spectrum of aeroplysinin-1 (53) $\left(600 \mathrm{MHz}, \mathrm{CD}_{3} \mathrm{OD}\right)$ 


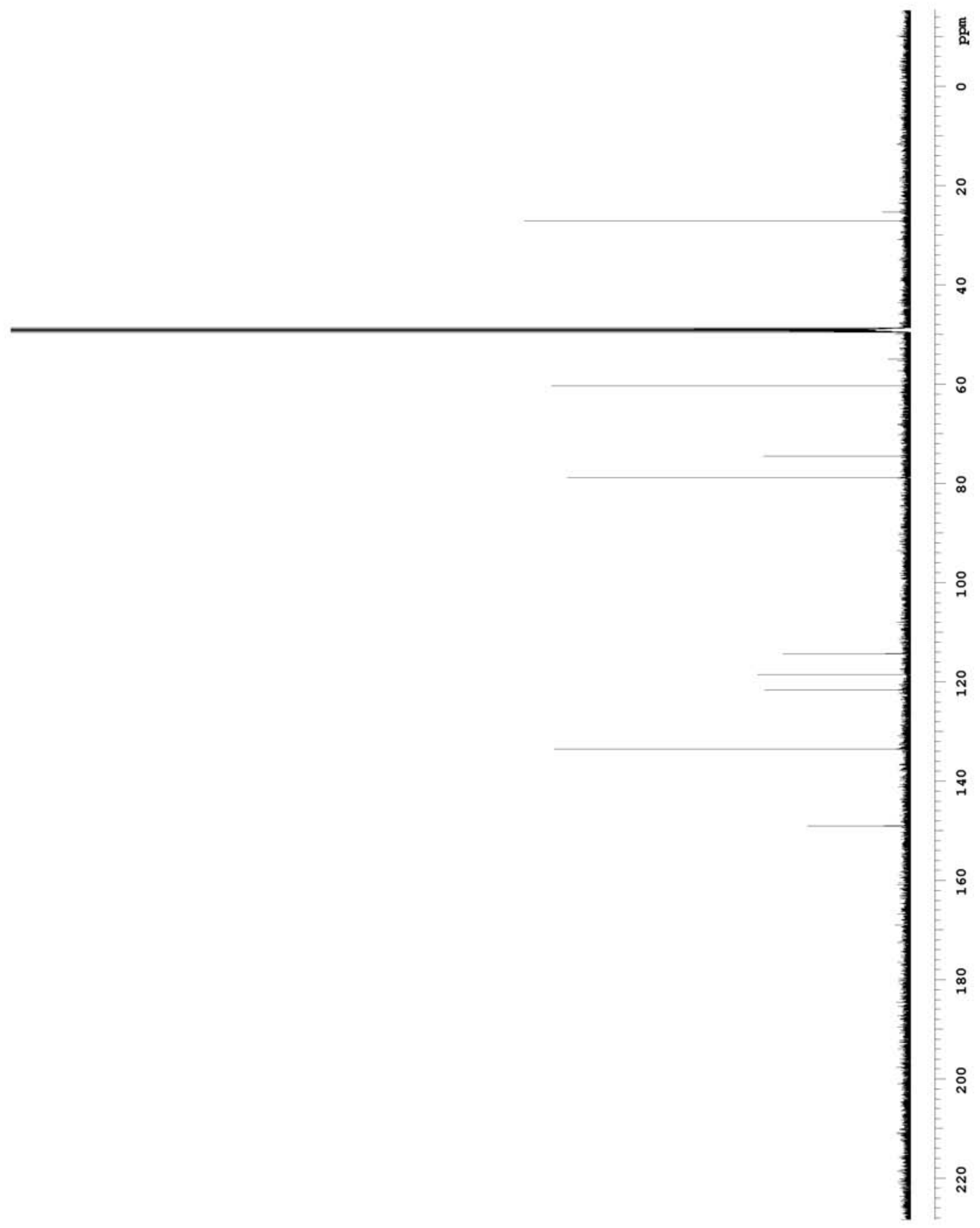

${ }^{13} \mathrm{C}$ spectrum of aeroplysinin-1 (53) $\left(150 \mathrm{MHz}, \mathrm{CD}_{3} \mathrm{OD}\right)$ 


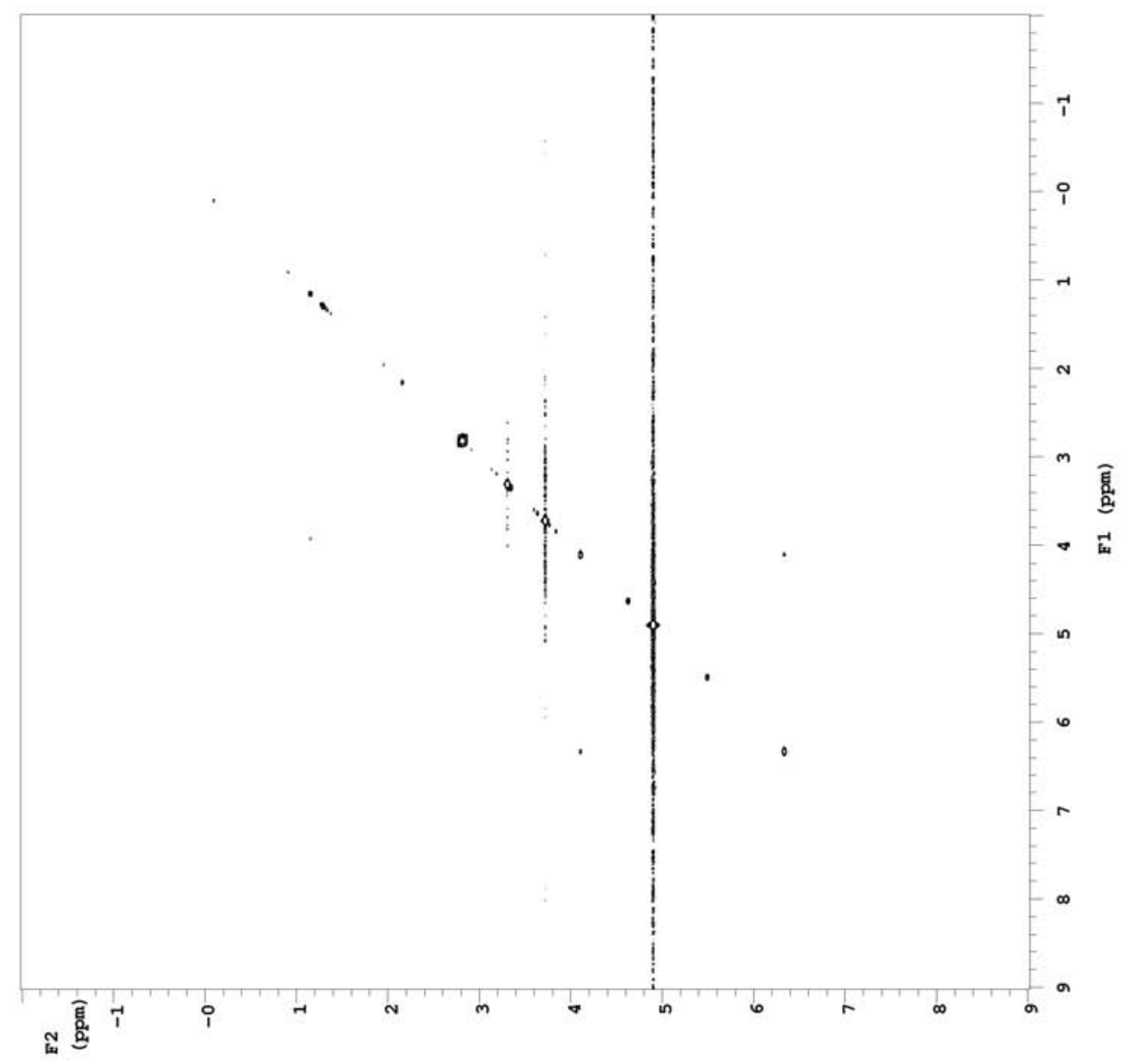

COSY spectrum of aeroplysinin-1 (53) $\left(600 \mathrm{MHz}, \mathrm{CD}_{3} \mathrm{OD}\right)$ 


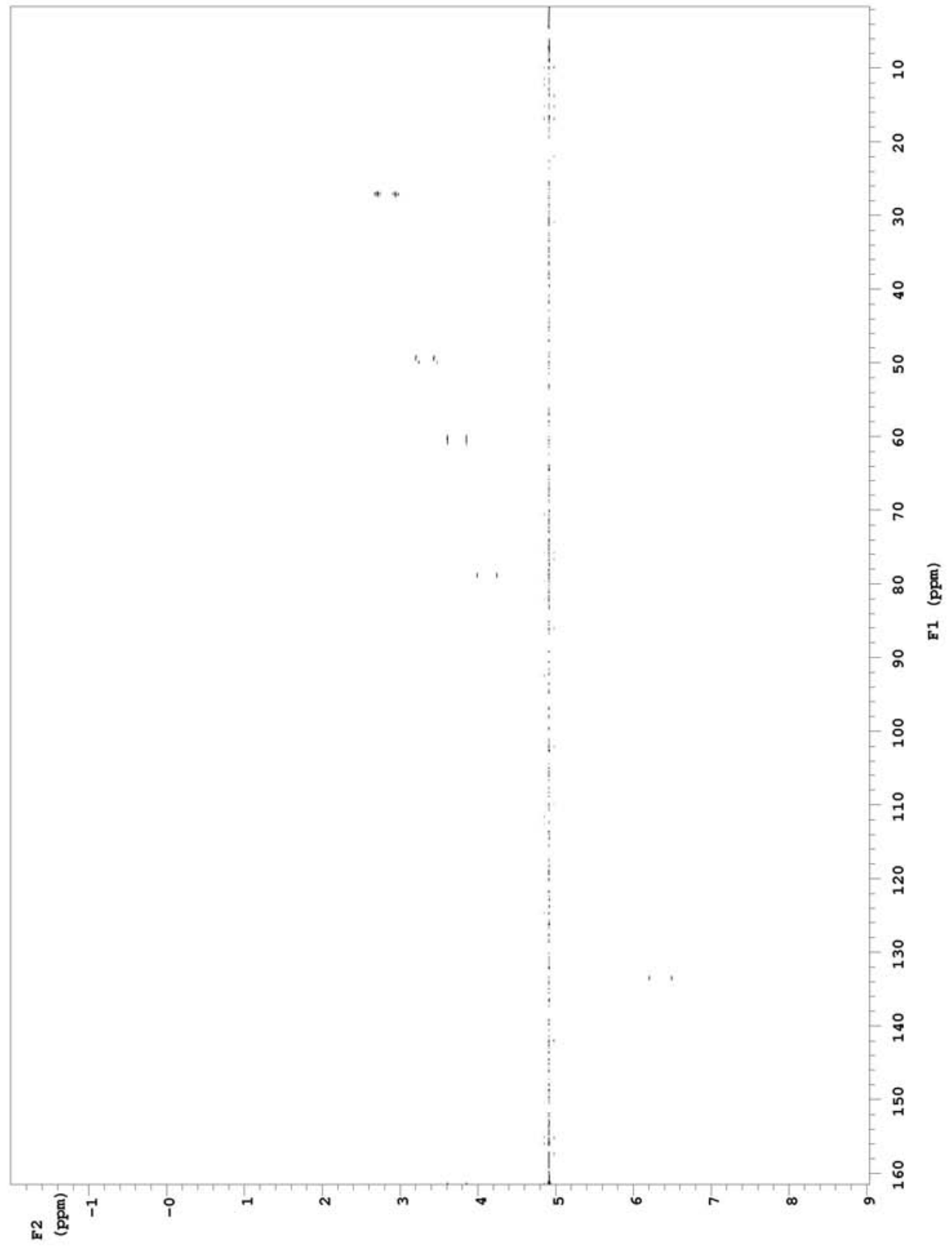

Coupled HSQC spectrum of aeroplysinin-1 (53) (600 MHz, $\left.\mathrm{CD}_{3} \mathrm{OD}\right)$ 


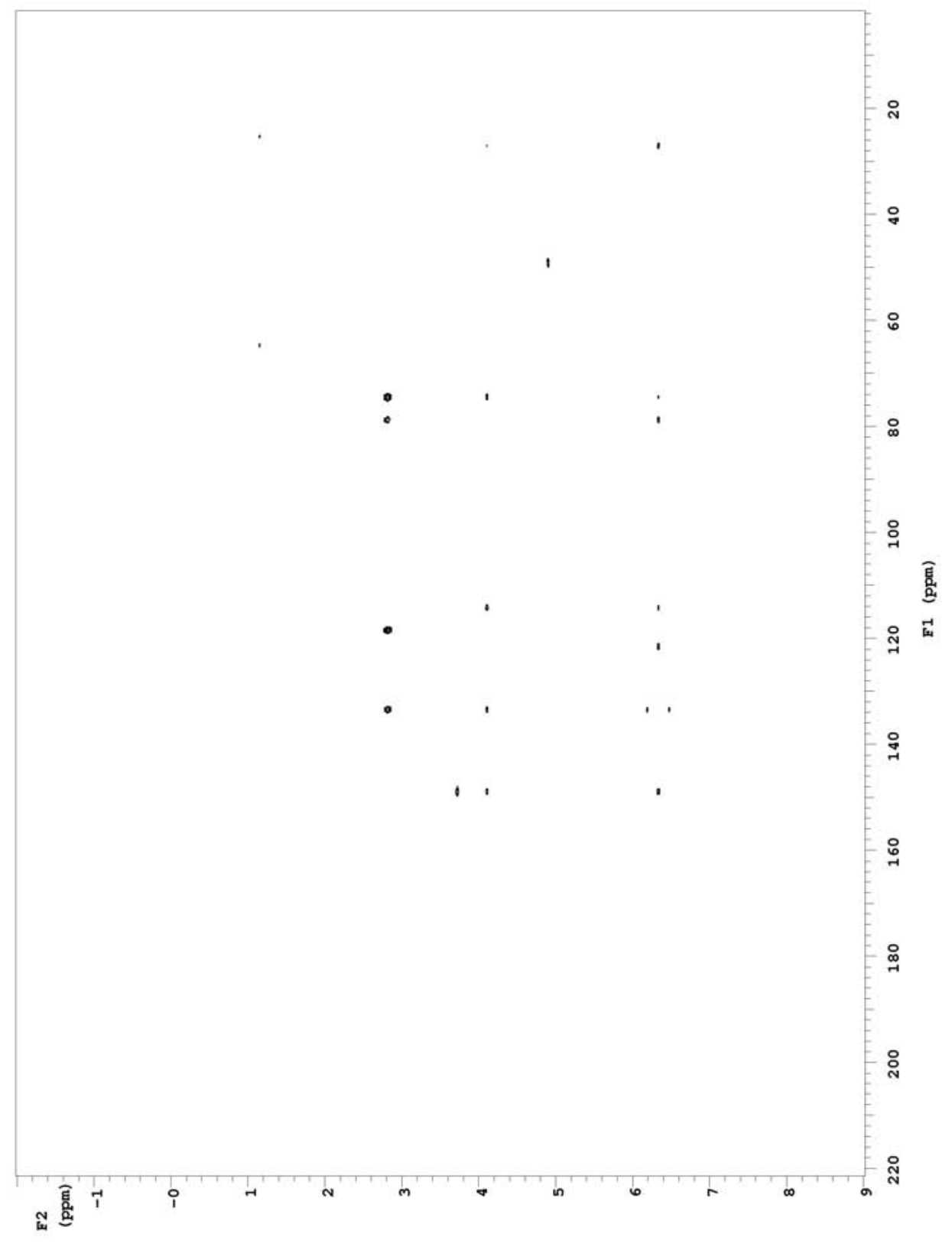

HMBC spectrum of aeroplysinin-1 (53) $\left(600 \mathrm{MHz}, \mathrm{CD}_{3} \mathrm{OD}\right)$ 
Appendix $G$

\section{LL-PAA216 Spectra}

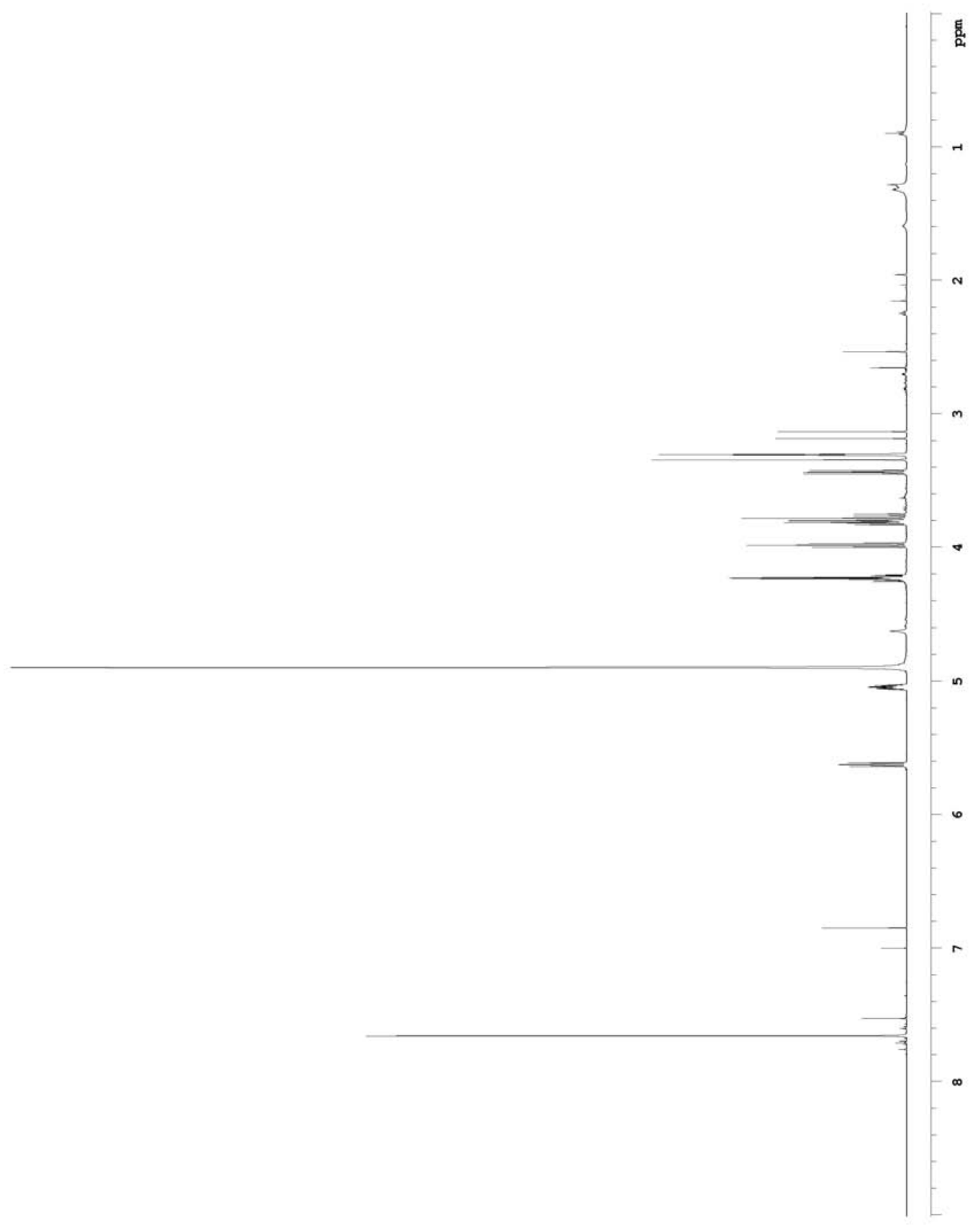

${ }^{1} \mathrm{H}$ NMR spectrum of LL-PAA216 (54) $\left(600 \mathrm{MHz}, \mathrm{CD}_{3} \mathrm{OD}\right)$ 


$$
1
$$




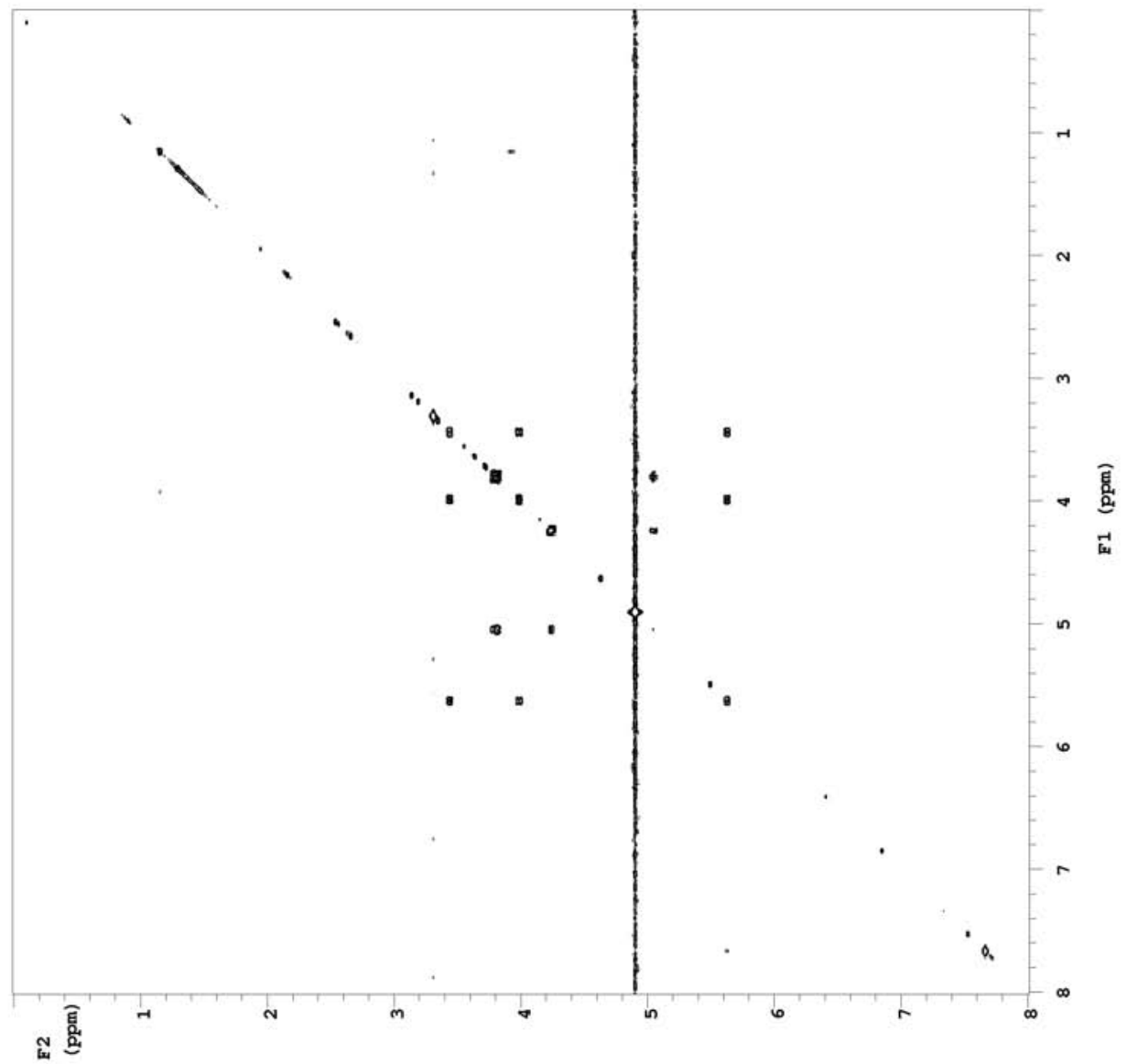

COSY spectrum of LL-PAA216 (54) $\left(600 \mathrm{MHz}, \mathrm{CD}_{3} \mathrm{OD}\right)$ 


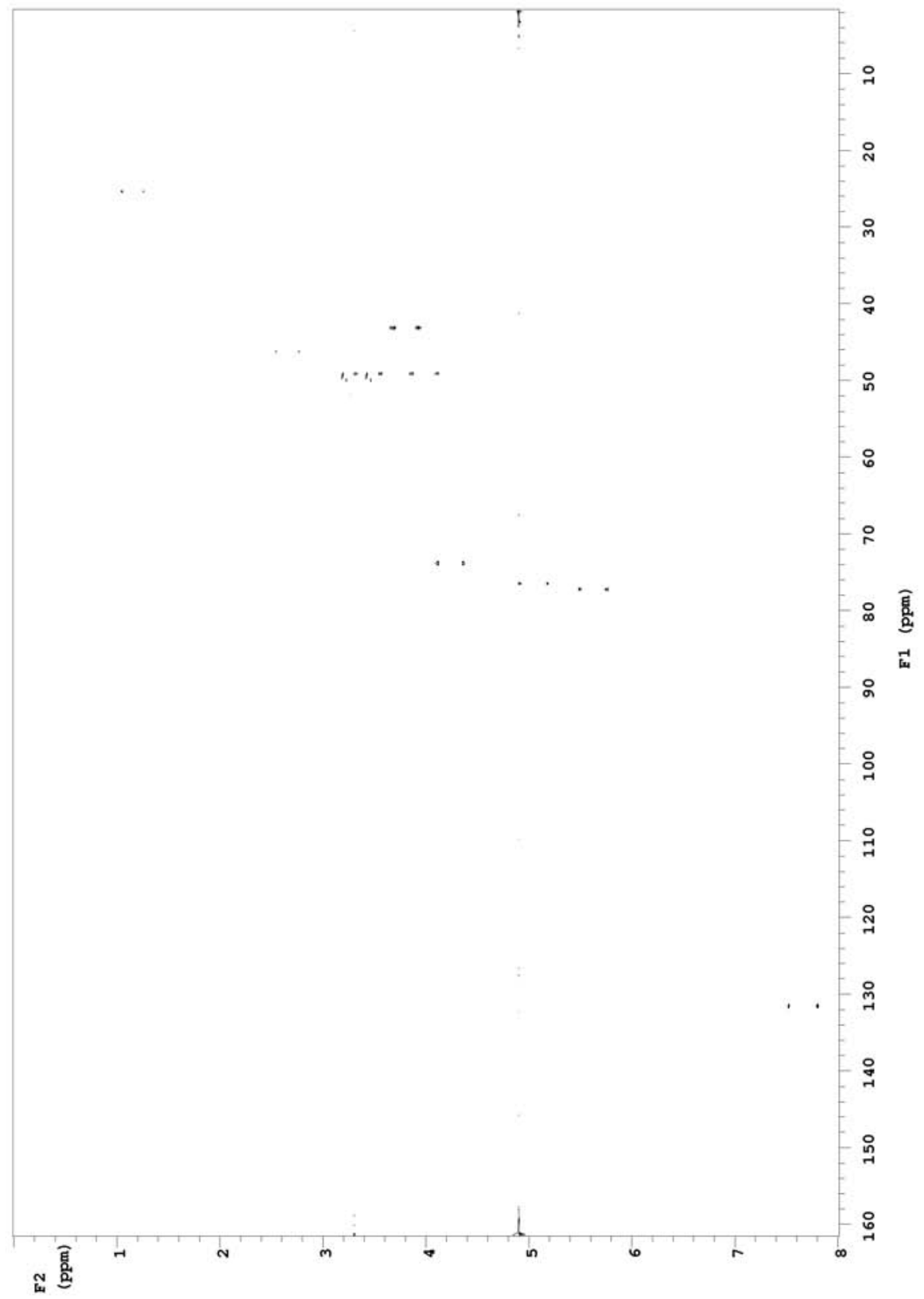

Coupled HSQC spectrum of LL-PAA216 (54) (600 MHz, $\left.\mathrm{CD}_{3} \mathrm{OD}\right)$ 


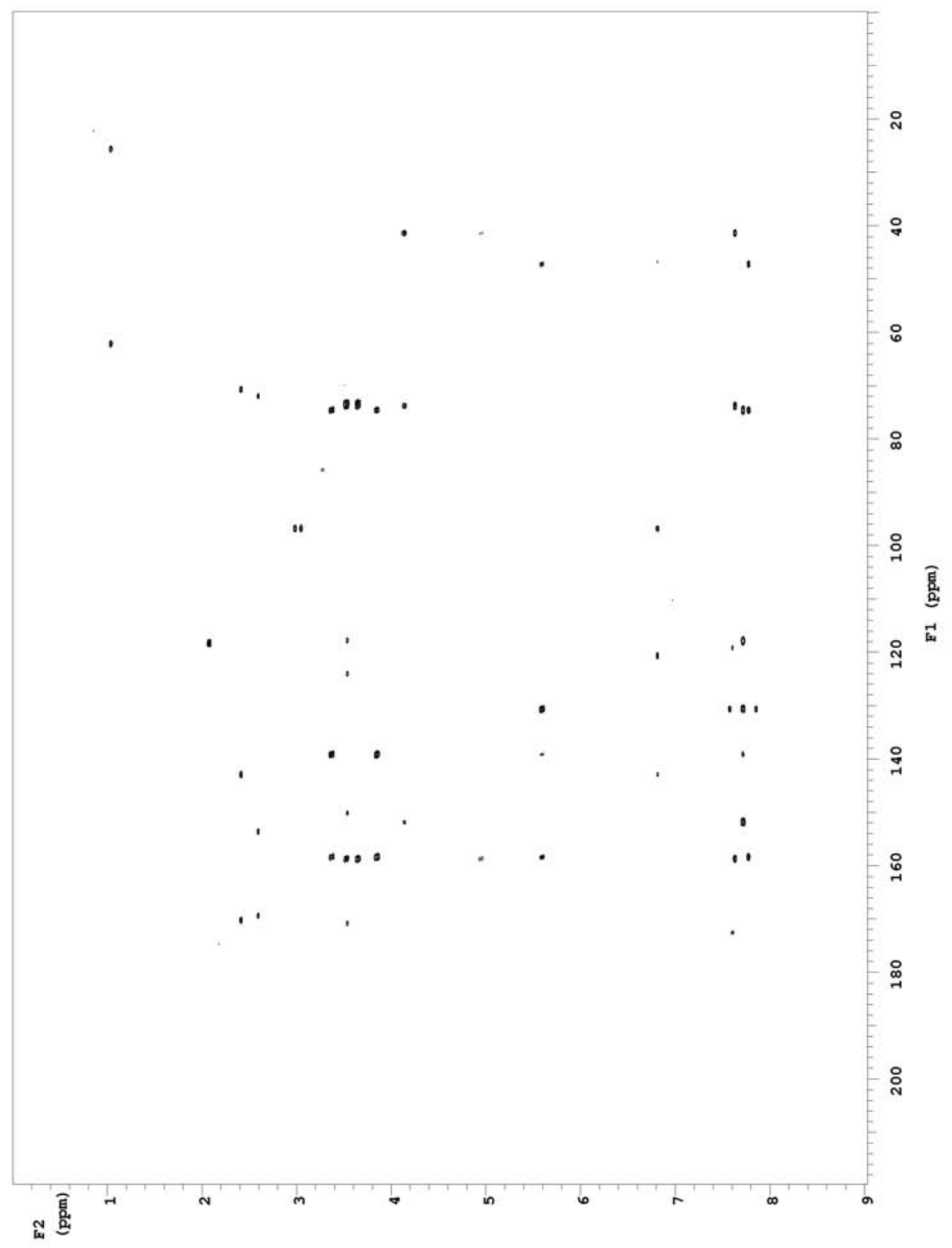

HMBC spectrum of LL-PAA216 (54) $\left(600 \mathrm{MHz}, \mathrm{CD}_{3} \mathrm{OD}\right)$ 


\section{LL-PAA216 Spectra}

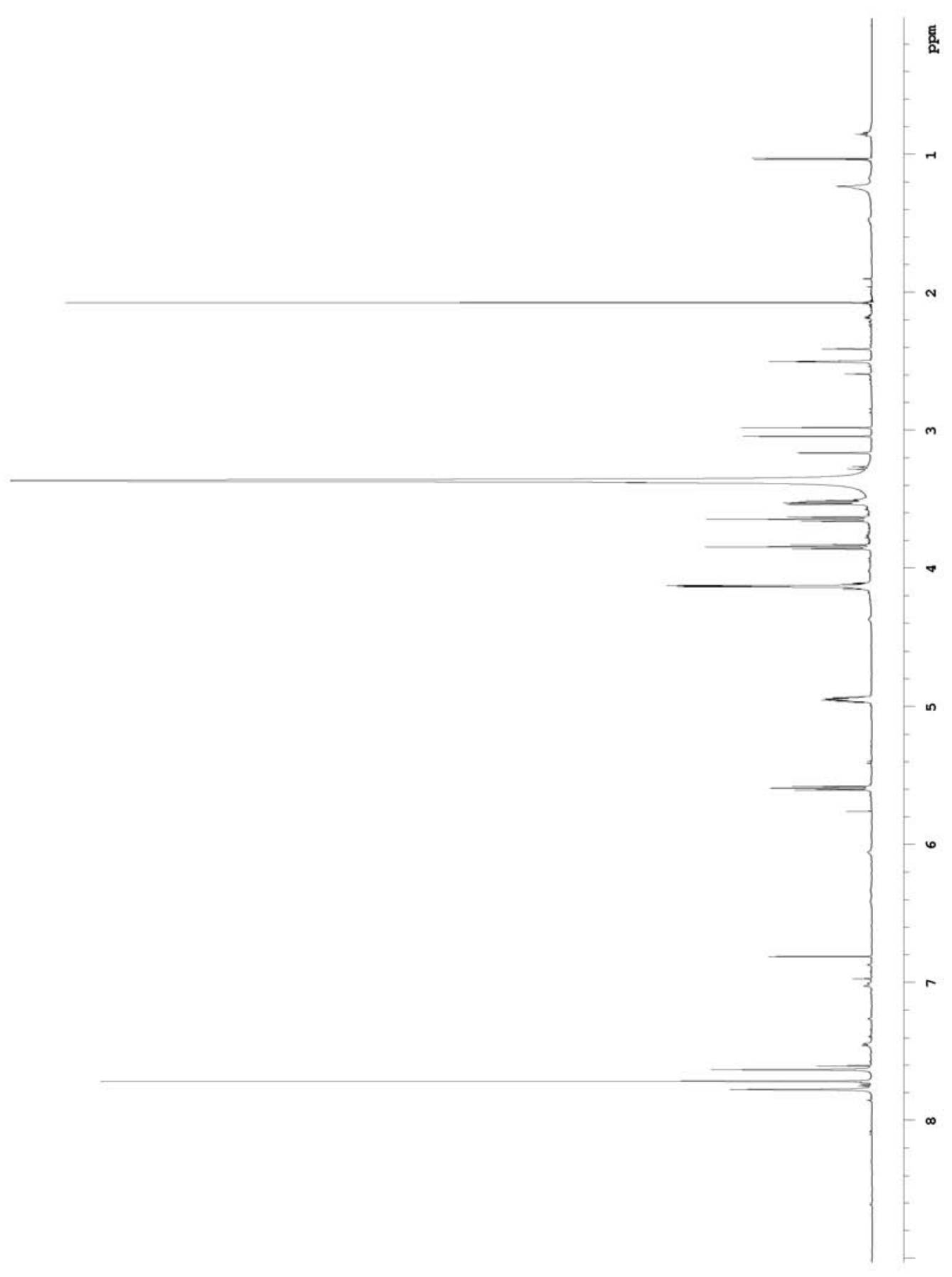

${ }^{1} \mathrm{H}$ NMR spectrum of LL-PAA216 (54) (600 MHz, $\mathrm{d}_{6}$-DMSO) 


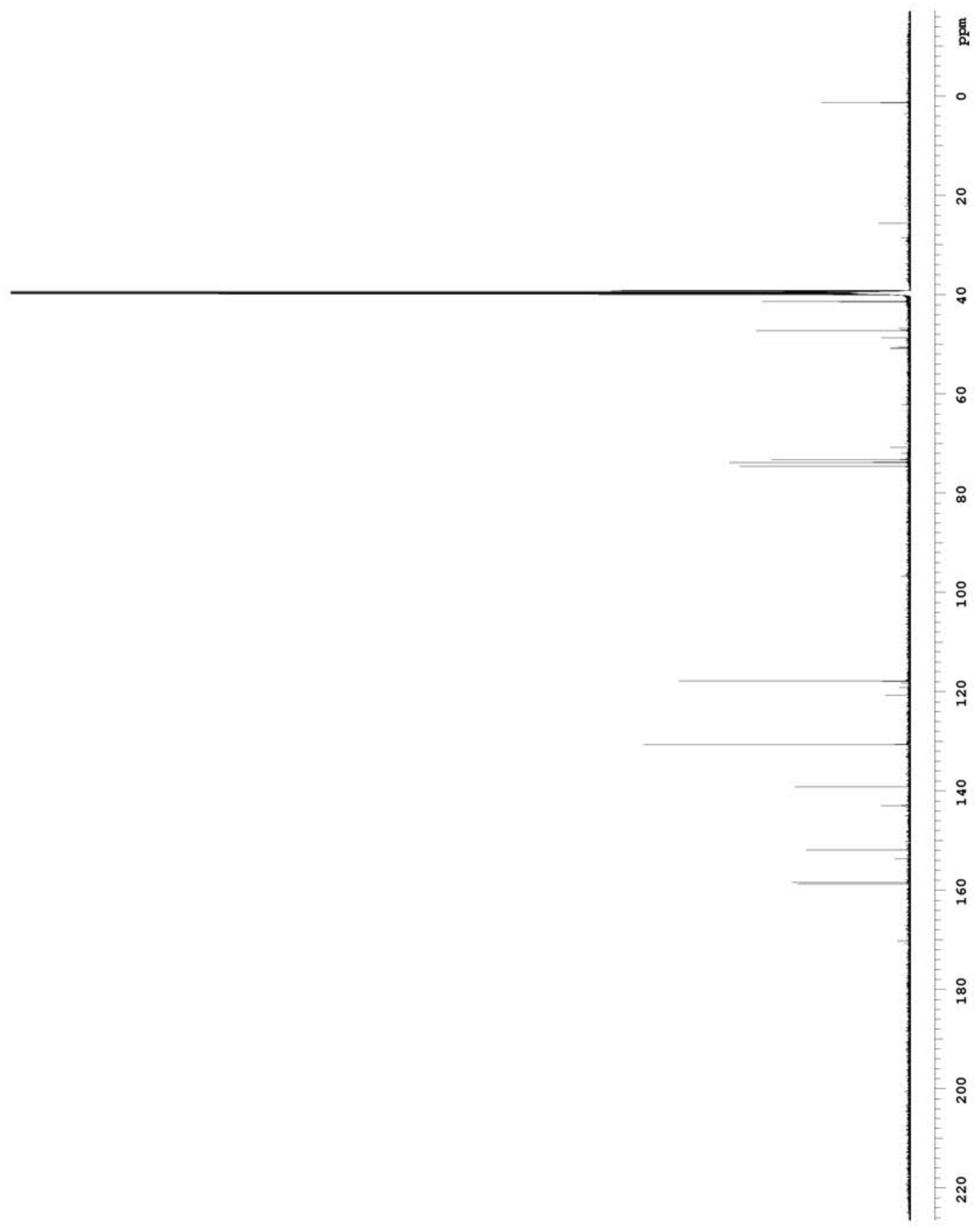

${ }^{13} \mathrm{C}$ spectrum of LL-PAA216 (54) $\left(150 \mathrm{MHz}, \mathrm{d}_{6}-\mathrm{DMSO}\right)$ 


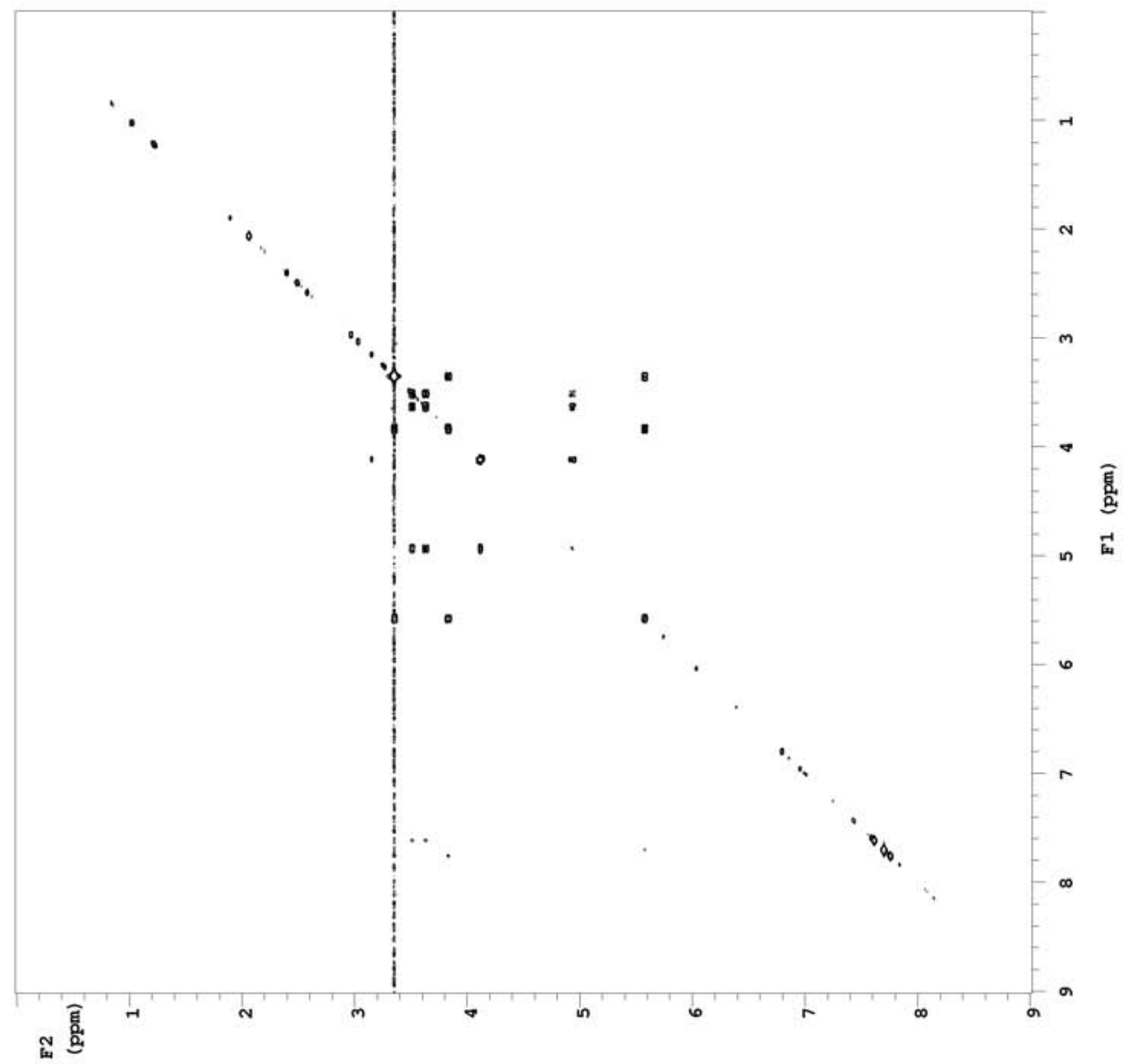

COSY spectrum of LL-PAA216 (54) $\left(600 \mathrm{MHz}, \mathrm{d}_{6}\right.$-DMSO) 


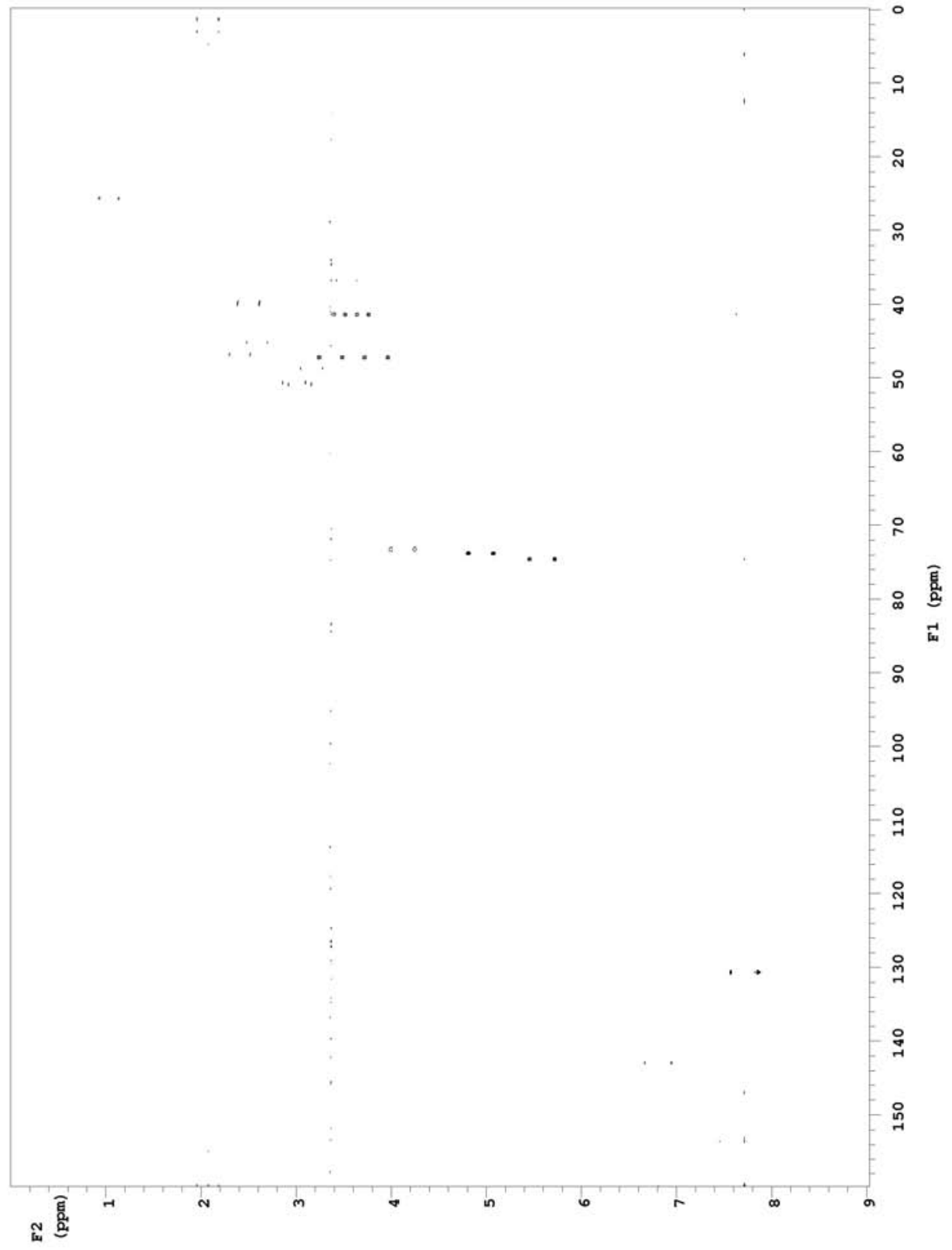

Coupled HSQC spectrum of LL-PAA216 (54) (600 MHz, $\mathrm{d}_{6}$-DMSO) 


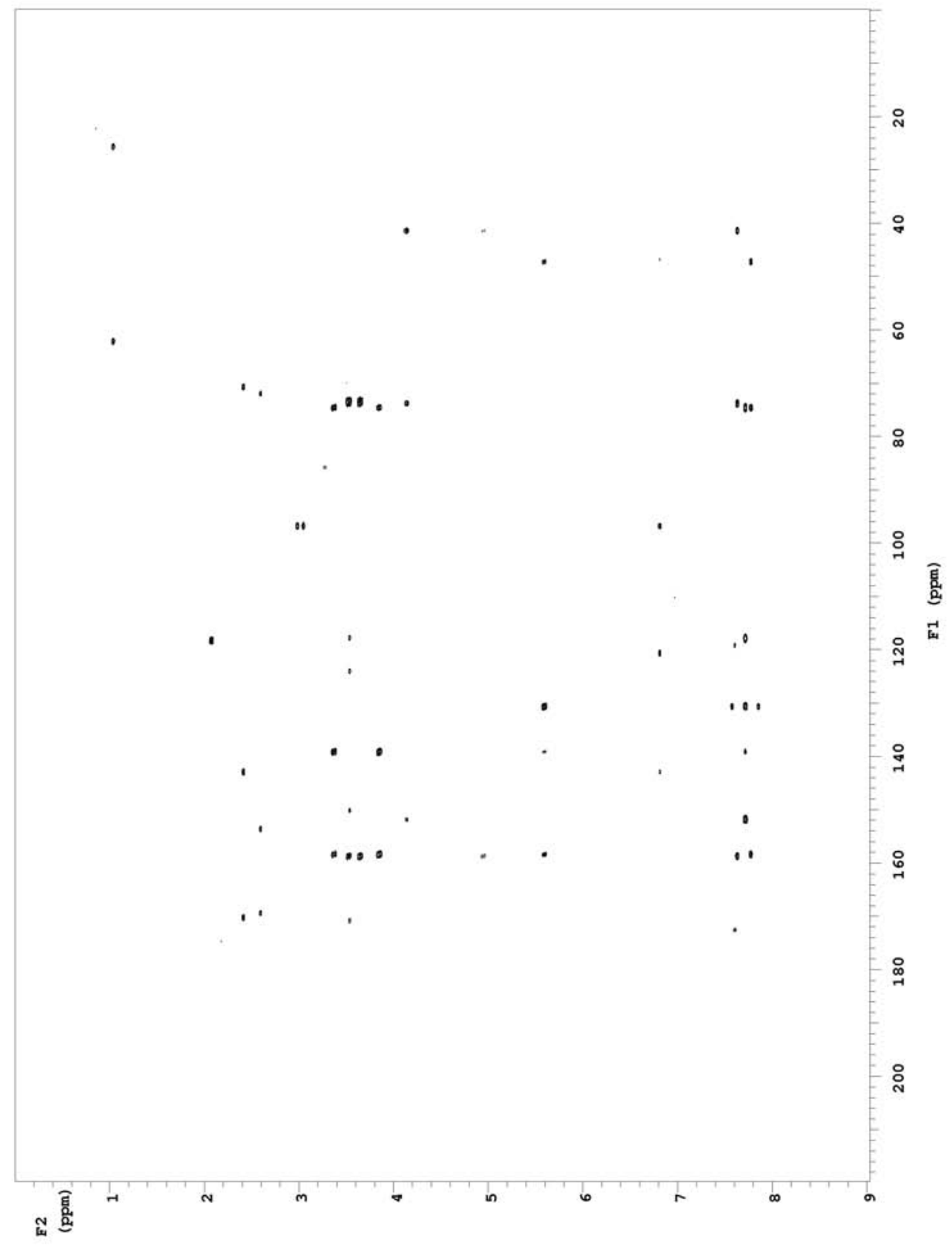

HMBC spectrum of LL-PAA216 (54) (600 MHz, $\mathrm{d}_{6}$-DMSO) 


\section{References}

1. Cragg, G. M.; Boyd, M. R.; Khanna, R.; Kneller, R.; Mays, T. D.; Mazan, K. D.; Newman, D. J.; Sausville, E. A. Pure Appl. Chem. 1999, 71, 1619-1633.

2. Newman, D. J.; Cragg, G. M.; Snader, K. M. Nat. Prod. Rep. 2000, 17, 215-234.

3. Drug discovery handbook; Gad, S. C., Ed.; John Wiley \& Sons: New Jersey, 2005.

4. Drug discovery from nature; Grabley, S., Thiericke, R., Eds.; Springer-Verlag: Berlin, 1999.

5. Baker, D. D.; Chu, M.; Oza, U.; Rajgarhia, V. Nat. Prod. Rep. 2007, 24, 1225-1244.

6. Davies, J. Can. J. Infect. Dis. Med. Microbiol. 2006, 17, 287-290.

7. Cragg, G. M.; Newman, D. J. Expert Opin. Investig. Drugs 2000, 9, 2783-2797.

8. Haefner, B. Drug Discov. Today 2003, 8, 536-544.

9. Donia, M.; Hamann, M. T. Lancet Infectious Diseases 2003, 3, 338-348.

10. Capon, R. J. Eur. J. Org. Chem. 2001, 4, 633-645.

11. Wallace, R. W. Mol. Med. Today 1997, 3, 291-295.

12. Jaspars, M. Chemistry \& Industry 1999, 2, 51-55.

13. Cragg, G. M.; Newman, D. J.; Snader, K. M. J. Nat. Prod. 1997, 60, 52-60.

14. Bergmann, W.; Feeney, R. J. J. Am. Chem. Soc. 1950, 72, 2809-2810.

15. Bergmann, W.; Feeney, R. J. J. Org. Chem. 1951, 16, 981-987.

16. Bergmann, W.; Burke, D. C. J. Org. Chem. 1955, 20, 1501-1507.

17. Bodey, G. P.; Freireich, E. J.; Monto, R. W.; Hewlett, J. S. Cancer Chemother. Rep. 1969, 53, 59-66.

18. Faulkner, D. J. Nat. Prod. Rep. 2000, 17, 1-6.

19. Bergquist, P. R. Sponges; Hutchinson \& Co.: London, 1978.

20. Dawkins, R. The Ancestor's Tale: A Pilgrimage to the Dawn of Life, 1st ed.; Houghton Mifflin: New York, 2004.

21. Systema Porifera : a guide to the classification of sponges; Hooper, J. N. A., van Soest, R. W. M., Willenz, P., Eds.; Kluwer Academic/Plenum Publishers: New York, 2002.

22. Enticknap, J. J.; Kelly, M.; Peraud, O.; Hill, R. T. Appl. Environ. Microbiol. 2006, $72,3724-3732$.

23. Vacelet, J.; Donadey, C. J. Exp. Mar. Biol. Ecol. 1977, 30, 301-314.

24. Faulkner, D. J.; Unson, M. D.; Bewley, C. A. Pure Appl. Chem. 1994, 66, 19831990. 
25. Bewley, C. A.; Faulkner, D. J. Angew. Chem. Int. Ed 1998, 37, 2163-2178.

26. Keyzers, R. A.; Northcote, P. T.; Davies-Coleman, M. T. Nat. Prod. Rep. 2006, 23, 321-334.

27. Sperry, S.; Valeriote, F. A.; Corbett, T. H.; Crews, P. J. Nat. Prod. 1998, 61, 241247.

28. Manes, L. V.; Bakus, G. J.; Crews, P. Tetrahedron Lett. 1984, 25, 931-934.

29. Kelly-Borges, M.; Vacelet, J. Mem. Queensl. Mus. 1995, 38, 477-503.

30. Crews, P.; Bescansa, P.; Bakus, G. J. Experientia 1985, 41, 690-1.

31. Crews, P.; Bescansa, P. J. Nat. Prod. 1986, 49, 1041-52.

32. Jaisamut, S.; Thengyai, S.; Yuenyongsawad, S.; Karalai, C.; Plubrukarn, A.; Suwanborirux, K. Pure Appl. Chem. 2009, 81, 1019-1026.

33. Quiñoà, E.; Crews, P. Tetrahedron Lett. 1987, 28, 3229-3232.

34. Sashidhara, K. V.; White, K. N.; Crews, P. J. Nat. Prod. 2009, 72, 588-603.

35. Kim, D. Y.; Lee, I. S.; Jung, J. H.; Yang, S. I. Arch. Pharm. Res. 1999, 22, 25-29.

36. Nicholas, G. M.; Eckman, L. L.; Ray, S.; Hughes, R. O.; Pfefferkorn, J. A.; Barluenga, S.; Nicolaou, K. C.; Bewley, C. A. Bioorg. Med. Chem. Lett. 2002, 12, 2487-2490.

37. Nicolaou, K. C.; Hughes, R.; Pfefferkorn, J. A.; Barluenga, S.; Roecker, A. J. Chem. Eur. J. 2001, 7, 4280-4295.

38. Nicolaou, K. C.; Hughes, R.; Pfefferkorn, J. A.; Barluenga, S. Chem. Eur. J. 2001, 7, 4296-4310.

39. Piña, I. C.; Gautschi, J. T.; Wang, G. Y. S.; Sanders, M. L.; Schmitz, F. J.; France, D.; Cornell-Kennon, S.; Sambucetti, L. C.; Remiszewski, S. W.; Perez, L. B.; Bair, K. W.; Crews, P. J. Org. Chem. 2003, 68, 3866-3873.

40. Shim, J. S.; Lee, H. S.; Shin, J.; Kwon, H. J. Cancer Lett. 2004, 203, 163-169.

41. Jiang, Y. H.; Ahn, E. Y.; Ryu, S. H.; Kim, D. K.; Park, J. S.; Yoon, H. J.; You, S.; Lee, B. J.; Lee, D. S.; Jung, J. H. BMC Cancer 2004, 4, 1471-2407.

42. Kim, D.; Lee, I. S.; Jung, J. H.; Lee, C. O.; Choi, S. U. Anticancer. Res. 1999, 19, 4085-4090.

43. Shin, J.; Lee, H. S.; Seo, Y.; Rho, J. R.; Cho, K. W.; Paul, V. J. Tetrahedron 2000 , 56, 9071-9077.

44. Tabudravu, J. N.; Eijsink, V. G. H.; Gooday, G. W.; Jaspars, M.; Komander, D.; Legg, M.; Synstad, B.; van Aalten, D. M. F. Bioorg. Med. Chem. 2002, 10, 11231128.

45. Meragelman, K. M.; McKee, T. C.; Boyd, M. R. J. Nat. Prod. 2001, 64, 389-392.

46. Field, J. J.; Singh, A. J.; Kanakkanthara, A.; Halafihi, T.; Northcote, P. T.; Miller, J. H. J. Med. Chem 2009, 52, 7328-7332. 
47. Tanaka, J.; Higa, T. Tetrahedron Lett. 1996, 37, 5535-5538.

48. Morris, G.; Fornier, N. Clin. Cancer Res. 2008, 14, 7167-7172.

49. Jordan, M. A.; Wilson, L. W. Nat. Rev. 2004, 4, 253-265.

50. Miller, J. H.; Singh, A. J.; Northcote, P. T. Mar. Drugs 2010, 8, 1059-1079.

51. Lipinski, C. A.; Lombardo, F.; Dominy, B. W.; Feeney, P. J. Adv. Drug Deliv. Rev 1997, 23, 3-25.

52. West, L. M. The isolation of Secondary Metabolites from New Zealand Marine Sponges, PhD, Victoria University of Wellington, 2001.

53. Singh, A. J. Secondary Metabolites from the New Zealand Marine Sponge Mycale hentscheli, MSc, Victoria University of Wellington, 2007.

54. Ryan, J. M. Novel Secondary Metabolites from New Zealand Marine Sponges, PhD, Victoria University of Wellington, 2007.

55. Wojnar, J. M. Isolation of New Secondary Metabolites from New Zealand Marine Invertebrates, $\mathrm{PhD}$, Victoria University of Wellington, 2008.

56. Dowle, K. O. New Nitrogenous Spongian Diterpenes from the New Zealand Marine Sponge Darwinella oxeata, MSc, Victoria University of Wellington, 2008.

57. Popplewell, W. L. Isolation and Structure Elucidation of New Secondary Metabolites from New Zealand Marine Red Algae, PhD, Victoria University of Wellington, 2008.

58. Capon, R. J.; Macleod, J. K. Aust. J. Chem. 1987, 40, 341-346.

59. Minale, L.; Cimino, G.; DeStefano, S.; Sodano, G. Fortschr. Chem. Org. Naturst. 1976, 33, 1-72.

60. Yagi, H.; Matsunage, S.; Fusetani, N. Tetrahedron 1993, 49, 3749-3754.

61. Roll, M. D.; Chang, W. J. C.; Scheuer, P. J.; Gray, G. A.; Shoolery, J. N.; Matsumoto, G. K.; Van, D. G. D.; Clardy, J. J. Am. Chem. Soc. 1985, 107, 29162920.

62. Ichiba, T.; Scheuer, P. J. J. Org. Chem. 1993, 58, 4149-4150.

63. Copp, B. R.; Ireland, C. M. J. Nat. Prod. 1992, 55, 822-823.

64. Gopichand, Y.; Schmitz, F. J. Tetrahedron Lett. 1979, 41, 3921-3924.

65. Kernan, M. R.; Cambie, R. C.; Bergquist, P. R. J. Nat. Prod. 1990, 53, 615-622.

66. Pordesimo, O. E.; Schmitz, F. J. J. Org. Chem. 1990, 55, 4704-4709.

67. Kazluskas, R. L. R. O.; Murphy, P. T.; Wells, R. J. Tetrahedron Lett. 1980, 21, 2277-2280.

68. Carney, J. R.; Scheuer, P. J. J. Nat. Prod. 1993, 56, 153-157.

69. MarinLit: Marine Literature Database, 2010.

70. Rogers, E. W.; Molinski, T. F. J. Nat. Prod. 2007, 70, 1191. 
71. Motti, C. A.; Freckelton, M. L.; Tapiolas, D. M.; Willis, R. H. J. Nat. Prod. 2009, $72,290$.

72. Xynas, R.; Capon, R. J. Aust. J. Chem. 1989, 42, 1427-1433.

73. Cimino, G.; Rosa, S. D.; Stefano, S. D.; Self, R.; Sodano, G. Tetrahedron Lett. 1983, 24, 3029-3032.

74. Fattorusso, E.; Minale, L.; Sodano, G. J. Chem. Soc., Perkin Trans. 1 1972, 16-18.

75. Borders, D. B.; Morton, G. O.; Wetzel, E. R. Tetrahedron Lett. 1974, 31, 2709-2712.

76. Takada, N.; Watanabe, R.; Suenaga, K.; Yamada, K.; Ueda, K.; Kita, M.; Uemura, D. Tetrahedron Lett. 2001, 42, 5265-5267.

77. Hayakawa, I.; Teruya, T.; Kigoshi, H. Tetrahedron Lett. 2006, 47, 155-158.

78. Kita, M.; Tsunematsu, Y.; Hayakawa, I.; Kigoshi, H. Tetrahedron Lett. 2008, 49, 5383-5384.

79. Carney, J. R.; Scheuer, P. J.; Kellyborges, M. Tetrahedron 1993, 49, 8483-8486.

80. Radisky, D. C.; Radisky, E. S.; Barrows, L. R.; Copp, B. R.; Kramer, R. A.; Ireland, C. M. J. Am. Chem. Soc. 1993, 115, 1632 - 1638.

81. Schmidt, E. W.; Harper, M. K.; Faulkner, D. J. J. Nat. Prod. 1995, 58, $1861-1867$.

82. Cheng, J.; Ohizumi, Y.; Walchli, M. R.; Nakamura, H.; Hirata, Y.; Sasaki, T.; Kobayashi, J. J. Org. Chem. 1988, 53, 4621-4624.

83. Kobayashi, J.; Cheng, J.; Yamamura, S.; Ishibashi, M. Tetrahedron Lett. 1991, 32, $1227-1228$.

84. Antunes, E.; Copp, B. R.; Davies-Coleman, M. T.; Samaai, T. Nat. Prod. Rep. 2005, $22,62-72$.

85. Urban, S.; Hickford, S. J. H.; Blunt, J. W.; Munro, M. H. G. Curr. Org. Chem. 2000, 4, 765-807.

86. Leahy, D. Victoria University of Wellington, New Zealand. Personal communication, 2009.

87. Crews, P.; Naylor, S. Prog. Chem. Org. Nat. Prod. 1985, 48, 203-269.

88. Hanson, J. R. Nat. Prod. Rep. 1986, 3, 123-132.

89. Kazlauskas, R.; Murphy, P. T.; Quinn, R. J.; Wells, R. J. Tetrahedron Lett. 1977, $61-64$.

90. Roll, D. M.; Ireland, C. M.; Lu, H. S. M.; Clardy, J. J. Org. Chem. 1988, 53, 32763278 .

91. Jimènez, C.; Quiñoà, E.; Adamczeski, M.; Hunter, L. M.; Crews, P. J. Org. Chem. 1991, 56, 3403-3410.

92. Jimènez, C.; Quiñoà, E.; Crew, P. Tetrahedron Lett. 1991, 32, 1843-1846. 
93. Segraves, N. L.; Lopez, S.; Johnson, T. A.; Said, S. A.; Fu, X.; Schmitz, F. J.; Pietraszkiewicz, H.; Valeriote, F. A.; Crews, P. Tetrahedron Lett. 2003, 44, 34713475 .

94. Segraves, N. L.; Robinson, S. J.; Garcia, D.; Said, S. A.; Fu, X.; Schmitz, F. J.; Pietraszkiewicz, H.; Valeriote, F. A.; Crews, P. J. Nat. Prod. 2004, 67, 783-792.

95. Schmidt, E. W.; Faulkner, D. J. Tetrahedron Lett. 1996, 37, 3951-3954.

96. Sullivan, B.; Faulkner, D. Tetrahedron Lett. 1982, 23, 907-910.

97. Bishara, A.; Rudi, A.; Aknin, M.; Neumann, D.; Ben-Califa, N.; Kashman, Y. Org. Lett. 2008, 10, 4307-4309.

98. Bishara, A.; Rudi, A.; Aknin, M.; Neumann, D.; Ben-Califa, N.; Kashman, Y. Org. Lett. 2008, 10, 153-156.

99. Bishara, A.; Rudi, A.; Goldberg, I.; Aknin, M.; Neumann, D.; Ben-Califa, N.; Kashman, Y. Org. Lett. 2009, 11, 3538-3541.

100. Bishara, A.; Rudi, A.; Aknin, M.; Neumann, D.; Ben-Califa, N.; Kashman, Y. Tetrahedron 2010, 1-7.

101. Bishara, A.; Rudi, A.; Goldberg, I.; Aknin, M.; Kashman, Y. Tetrahedron Lett. 2009, $50,3820-3822$.

102. Bishara, A.; Rudi, A.; Aknin, M.; Neumann, D.; Ben-Califa, N.; Kashman, Y. Tetrahedron Lett. 2008, 49, 4355-4358.

103. Klein, D.; Braekman, J. C.; Daloze, D.; Hoffmann, L.; Demoulin, V. Tetrahedron Lett. 1996, 37, 7519-7520.

104. Klein, D.; Braekman, J. C.; Daloze, D.; Hoffman, L.; Castillo, G.; Demoulin, V. J. Nat. Prod. 1999, 62, 934-936.

105. Stratmann, K.; Burgoyne, D. L.; Moore, R. E.; Patterson, G. M. L.; Smith, C. D. J. Org. Chem. 1994, 59, 7219-7226.

106. Ratnayake, R.; Fremlin, L. J.; Lacey, E.; Gill, J. H.; Capon, R. J. J. Nat. Prod. 2008, 71, 403-408.

107. Seo, C.; Yim, J. H.; Lee, H. K.; Park, S. M.; Sohn, J. H.; Oh, H. Tetrahedron Lett. 2008, 49, 29-31.

108. Albizati, K. F.; Holman, T.; Faulkner, D. J.; Glaser, K. B.; Jacobs, R. S. Experientia 1987, 43, 949-950.

109. Yunker, M. B.; Scheuer, P. J. J. Am. Chem. Soc. 1978, 100, 307-309.

110. Tsuda, M.; Shigemori, H.; Ishibashi, M.; Sasaki, T.; Kobayashi, J. J. J. Org. Chem. 1992, 57, 3503-3507.

111. Höller, U.; König, G. M.; Wright, A. D. J. Nat. Prod. 1997, 60, 832-835.

112. Tran, N. H.; Hooper, J. N. A.; Capon, R. J. Aust. J. Chem. 1995, 48, 1757-1760.

113. Elkhayat, E.; Edrada, R. A.; Ebel, R.; Wray, V.; van Soest, R.; Wiryowidagdo, S.; Mohamed, M. H.; Müller, W. E. G.; Proksch, P. J. Nat. Prod. 2004, 67, 1809-1817. 
114. Kirsch, G.; Kong, G. M.; Wright, A. D.; Kaminsky, R. J. Nat. Prod. 2000, 63, 825829.

115. Ruzicka, Z. L. Experientia 1953, 9, 357-367.

116. Ebada, S. S.; Lin, W.; Proksch, P. Mar. Drugs 2010, 8, 313-346.

117. de Silva, E. D.; Scheuer, P. J. Tetrahedron Lett. 1980, 21, 1611-1614.

118. Butler, M. S.; Capon, R. J. Aust. J. Chem. 1992, 45, 1705-1743.

119. de Silva, E.; Scheuer, P. Tetrahedron Lett. 1981, 22, 3147-3150.

120. Bourguet-Kondracki, M. L.; Debitus, C.; Guyot, M. J. Chem. Res. (S) 1996, 192193.

121. Kobayashi, M.; Okamoto, T.; Hayashi, K.; Yokoyama, N.; Sasaki, T.; Kitagawa, I. Chem. Pharm. Bull. 1994, 42, 265-270.

122. Tasdemir, D.; Concepcion, G. P.; Mangalindan, G. C.; Harper, M. K.; Hajdu, E.; Ireland, C. M. Tetrahedron 2000, 56, 9025-9030.

123. de Rosa, S.; de Stefano, S.; Zavodnik, N. J. Org. Chem. 1988, 53, 5020-5023.

124. Cambie, R. C.; Craw, P. A.; Bergquist, P. R.; Karuso, P. J. Nat. Prod. 1988, 51, 331-334.

125. Cao, S.; Foster, C.; Lazo, J. S.; Kingston, D. G. Bioorg. Med. Chem. 2005, 13, 5094-5098.

126. Montagnac, A.; Pais, M.; Debitus, C. J. Nat. Prod. 1994, 57, 186-190.

127. de Rosa, S.; Crispino, A.; de Giulio, A.; Iodice, C.; Pronzato, R.; Zavodnik, N. J. Nat. Prod. 1995, 58, 1776-1780.

128. de Rosa, S.; Crispino, A.; de Giulio, A.; Iodice, C.; Tommonaro, G. J. Nat. Prod. 1997, 60, 844-846.

129. de Rosa, S.; Carbonelli, S. Tetrahedron 2006, 62, 2845-2849.

130. Tsuda, M.; Endo, T.; Mikami, Y.; Fromont, J.; Kobayashi, J. J. Nat. Prod. 2002, 65, 1507-1508.

131. Kernan, M. R.; Faulkner, D. J.; Jacobs, R. S. J. Org. Chem. 1987, 52, 3081-3083.

132. Kernan, M. R.; Faulkner, D. J.; Parkanyi, L.; Clardy, J.; de Carvalho, M. S.; Jacobs, R. S. Experientia 1989, 45, 388-390.

133. König, G. M.; Wright, A. D.; Sticher, O. J. Nat. Prod. 1992, 55, 174-178.

134. Potts, B. C. M.; Capon, R. J.; Faulkner, D. J. J. Org. Chem. 1992, 57, 2965-2967.

135. Reddy, M. V. R.; Harper, M. K.; Faulkner, D. J. J. Nat. Prod. 1997, 60, 41-43.

136. Namikoshi, M.; Suzuki, S.; Meguro, S.; Nagai, H.; Koike, Y.; Kitazawa, A.; Kobayashi, H.; Oda, T.; Yamada, J. Fish. Sci. 2004, 70, 152-158.

137. Ettinger-Epstein, P.; Motti, C. A.; de Nys, R.; Wright, A. D.; Battershill, C. N.; Tapiolas, D. M. J. Nat. Prod. 2007, 70, 648-651. 
138. Zhou, G. X.; Molinski, T. F. J. Asian Nat. Prod. Res. 2006, 8, 15-20.

139. Kobayashi, J.; Zeng, C. M.; Ishibashi, M.; Sasaki, T. J. Nat. Prod. 1993, 56, 436439.

140. Gauvin-Bialecki, A.; Aknin, M.; Smadja, J. Molecules 2008, 13, 3184-3191.

141. Ueoka, R.; Nakao, Y.; Fujii, S.; van Soest, R. W. M.; Matsunaga, S. J. Nat. Prod. 2008, 71, 1089-1091.

142. de Freitas, J. C.; Blankemeier, L. A.; Jacobs, R. S. Experientia 1984, 40, 864-865.

143. Glaser, K. B.; Jacobs, R. S. Biochem. Pharmacol. 1986, 35, 449-453.

144. Deems, R. A.; Lombardo, D.; Morgan, B. P.; Mihelich, E. D.; Dennis, E. A. Biochim. Biophys. Acta 1987, 917, 258-268.

145. Reynolds, L. J.; Morgan, B. P.; Hite, G. A.; Mihelich, E. D.; Dennis, E. A. J. Am. Chem. Soc. 1988, 110, 5172-5177.

146. Potts, B. C. M.; Faulkner, D. J.; Jacobs, R. S. J. Nat. Prod. 1992, 55, 1701-1717.

147. Reynolds, L. J.; Mihelich, E. D.; Dennis, E. A. J. Biol. Chem. 1991, 266, 1651216517.

148. Potts, B. C. M.; Faulkner, D. J.; de Carvalho, M.; Jacobs, R. S. J. Am. Chem. Soc. 1992, 114, 5093-5100.

149. de Rosa, M.; Giordano, S.; Scettri, A.; Sodano, G.; Soriente, A.; Pastor, P. G.; Alcaraz, M. J.; Pay, M. J. Med. Chem. 1998, 41, 3232-3238.

150. Mann, J. Nature 1992, 358, 540.

151. Glaser, K. B.; de Carvalho, M. S.; Jacobs, R. S.; Kernan, M. R.; Faulkner, D. J. Mol. Pharmacol. 1989, 36, 782-788.

152. Kernan, M. R.; Barrabee, E. B.; Faulkner, D. J. Comp. Biochem. Physiol. 1988, 89B, 275-278.

153. Faulkner, D. J. Synthesis 1971, 175-189.

154. Liu, Y.; Mansoor, T. A.; Hong, J.; Lee, C. O.; Sim, C. J.; Im, K. S.; Kim, N. D.; Jung, J. H. J. Nat. Prod. 2003, 66, 1451-1456.

155. Fattorusso, E.; Lanxotti, V.; Magno, S.; Mayol, L.; di Rosa, M.; Ialenti, A. Bioorg. Med. Chem. Lett. 1991, 1, 639-644.

156. de Rosa, S.; de Giulio, A.; Crispino, A.; Iodice, C.; Tommonaro, G. Nat. Prod. Lett. 1997, 10, 267-274.

157. Gottlieb, H. E.; Kotlyar, V.; Nudelman, A. J. Org. Chem. 1997, 62, 7512-7515. 